\title{
Review
}

\section{The mineralogy of suspended matter, fresh and Cenozoic sediments in the fluvio-deltaic Rhine-Meuse-Scheldt-Ems area, the Netherlands: An overview and review}

\section{J. Griffioen ${ }^{1, *}$, G. Klaver ${ }^{2}$ \& W.E. Westerhoff ${ }^{3}$}

1 TNO Geological Survey of the Netherlands, P.0. Box 80 015, 3508 TA Utrecht, the Netherlands and Copernicus Institute of Sustainable Development, Utrecht University, P.0. Box 80 115, 3508 TC Utrecht, the Netherlands

2 Formerly BRGM, Laboratories Division, 3 av. C. Guillemin, BP36009, 45060 Orleans, France; Le Studium, CNRS, Orleans, France; TN0 Geological Survey of the Netherlands, P.0. Box 80 015, 3508 TA Utrecht, the Netherlands

3 TNO Geological Survey of the Netherlands, P.0. Box 80 015, 3508 TA Utrecht, the Netherlands

* Corresponding author. Email: jasper.griffioen@tno.nl

Manuscript received: 18 March 2015, accepted: 13 0ctober 2015

\section{Abstract}

Minerals are the building blocks of clastic sediments and play an important role with respect to the physico-chemical properties of the sediment and the lithostratigraphy of sediments. This paper aims to provide an overview of the mineralogy (including solid organic matter) of sediments as well as suspended matter as found in the Netherlands (and some parts of Belgium). The work is based on a review of the scientific literature published over more than 100 years. Cenozoic sediments are addressed together with suspended matter and recent sediments of the surface water systems because they form a geoscientific continuum from material subject to transport via recently settled to aged material. Most attention is paid to heavy minerals, clay minerals, feldspars, Ca carbonates, reactive Fe minerals (oxides, siderite, sulphides, glauconite) and solid organic matter because they represent the dominant minerals and their properties form a main issue in subsurface and water management. When possible and relevant, the amounts, provenance, relationship with grain size distribution, early diagenesis and palaeohydrological evolution are described. Tables with statistical data about the mineral contents and isotopic composition of carbonates and organic matter are presented as overviews. The review on the mineralogy of Dutch fluvial and marine environments is more extensive than that for the other sedimentary environments because the first two have been studied much more intensively than the others and they also form the larger part of the Dutch deposits. The focus is on the natural background mineralogy of Dutch sediments, but this is hard for recent sediments, largely because the massive hydraulic infrastructure present in the Netherlands has probably also affected the mineralogy and geochemistry of sediments deposited in recent centuries. Many findings are summarised, several of which lead to more general insights for the Dutch situation. Ca carbonates in sediments often have several provenances and thus must be considered as mixtures. Dolomite is commonly present in addition to calcite. The importance of biotite as weatherable mica is unclear. Weathering of heavy minerals plays some role but it is unclear in which way it affects the heavy mineral associations. Clays are usually dominated by illite, smectite and their interstratified variant, while kaolinite is usually below $20 \%$ and chlorite below $5 \%$. Vermiculite is a minor constituent in fluvial clays and its illitisation presumably happens during early diagenesis in the marine environment. Opaque Fe hydroxides can be present in addition to Fe oxyhydroxide coatings and both will play a role in redox chemistry as reactive Fe minerals. Feldspars in marine sediments must be present but they have not been properly studied. The genesis of rattle stones and carbonate concretions has not been completely elucidated. The fraction of terrigeneous organic matter in estuarine and coastal marine sediments is substantial. The available data and information are spread irregularly over the country and the reviewed information discussed in this paper is derived from relatively small-scale studies dealing with a limited amount of analysed samples. Much information is available from the Scheldt estuaries in the southwestern part of the Netherlands partly due to the severe contamination of the Western Scheldt in recent decades. 


\section{Introduction}

Mineral grains are the building blocks of clastic sediments. The mixture of minerals together with organic matter influences the pore water composition, the soil's pedological evolution and fertility, the fate of pollutants in the subsurface, the porosity and permeability as geohydrological properties and the geomechanical strength of the subsurface. More specifically, mineralogical composition plays an important role in sediment reactivity (Van Gaans et al., 2011), greatly influencing surface complexation and ion exchange of cations and anions, sorption of organic substances, denitrification and other redox reactions, as well as the weathering processes. Insight into this reactivity is needed for environmental management issues such as drainageinduced oxidation, aquifer storage and recovery, natural attenuation of pollutants, leaching of nutrients from farmland, reactive transport and secondary mobilisation of trace metals, and transfer of pollutants or nutrients from aquatic sediments to the water column or vice versa. Additionally, the reactivity of sediment influences the $\mathrm{pH}$ and redox state of the subsurface and hence the stability of the subsurface, man-made constructions and buried materials (examples being the corrosion of steel constructions and the stability of archaeological heritage).

The mineralogy of sediments is also used to stratigraphically classify sediments and to characterise their provenance. Heavy minerals (i.e. having a specific density exceeding 2.85 $\mathrm{kg} / \mathrm{dm}^{3}$; Boggs, 2009) are traditionally used for this purpose, but this is labour-intensive and is nowadays rarely applied in the Netherlands. The clay mineralogy may also be used as a palaeogeographical tool to characterise past climatological conditions and the provenance of sediments (Tebbens et al., 1998; Thiry, 2000; Zeelmaekers, 2011). The nature of quartz, mica and feldspar grains also assists in the visual recognition of different kinds of sediments: the presence or absence of multicoloured quartz and of mica are important criteria when visually classifying Dutch fluvial and other sediments stratigraphically (De Mulder et al., 2003). Other criteria often used are the presence of glauconite, shells or, more generally, Ca carbonate (using the effervescence test).

More abstractly, sediments and suspended matter are both important in the biogeochemical cycling of the elements and the functioning of ecosystems. For example, the source/sink function of dissolved substances and the food function of benthic organisms are controlled by the reactivity of sediments (including the state of particulate organic matter) and thus by their mineralogy. Additionally, the factors determining the erosion-transport-sedimentation behaviour and related flocculation/deflocculation behaviour include the physico-chemical properties of the minerals involved.
From the foregoing it is clear that insight into the mineralogical composition of sediments is of general relevance. This being the case, it is surprising that there has been no overview of the mineralogical composition of sediments in the Netherlands. A wealth of information is available on the geology of the Netherlands, and several books present geological overviews of the country (De Mulder et al., 2003; Wong et al., 2007 are the most recent and extensive ones). However, these kinds of texts address the mineralogy in a qualitative and restricted way, focusing on distinguishing and grouping heavy minerals for stratigraphical reasons. This paper therefore aims to provide an overview of the mineralogy and organic geochemistry of sediments as well as suspended matter as found in the Netherlands (and some parts of Belgium), based on an extensive review of the scientific literature of more than a century. We address suspended matter, recent sediments of the surface water systems and Cenozoic sediments because they form a geoscientific continuum: recent marine and fluvial sediments as well as suspended matter are the present-day analogues of the geological sediments. Most attention is paid to the following groups of minerals, with an indication of their relevance: heavy minerals as indicators of provenance etc., clay minerals for their contribution to the sorption capacity and impact on geohydrological and geomechanical properties, feldspars as major, weatherable Al silicates, Ca carbonates as reactive, $\mathrm{pH}$ buffering minerals, reactive Fe minerals (oxides, carbonates, sulphides, glauconite) for their overall reactive behaviour, and solid organic matter for its redox-controlling and sorptive capacities. The review has been limited to the Cenozoic sediments because there is little literature on older sediments for which integration is less needed (an exception being the Rotliegend Sandstone, which is the most important natural gas reservoir rock in the Netherlands and has therefore been intensively studied; Gaupp \& 0kkerman, 2011). The sediments are predominantly clastic; organic or chemical sediments play a minor role in the Cenozoic records of the Netherlands.

Fig. 1 presents a map of the Netherlands with all geographical names used in this paper. Section 2 presents a brief overview of the geology and geography of the Netherlands. The review method is described in section 3, together with several methodological analytical approaches that have been applied by researchers. In the Netherlands, the mineralogy of fluvial and marine environments has been studied much more intensively than that of glacial, aeolian, lacustrine and peat environments, and so separate sections ( 4 and 5) are devoted to them. When possible and relevant, the amounts, provenance, relationship with grain size, early diagenesis and palaeohydrological evolution are described per type of mineral. The findings for the other sedimentological environments are fragmented; they are described in section 6 . The general discussion presented in section 7 evaluates and integrates several of the findings. 


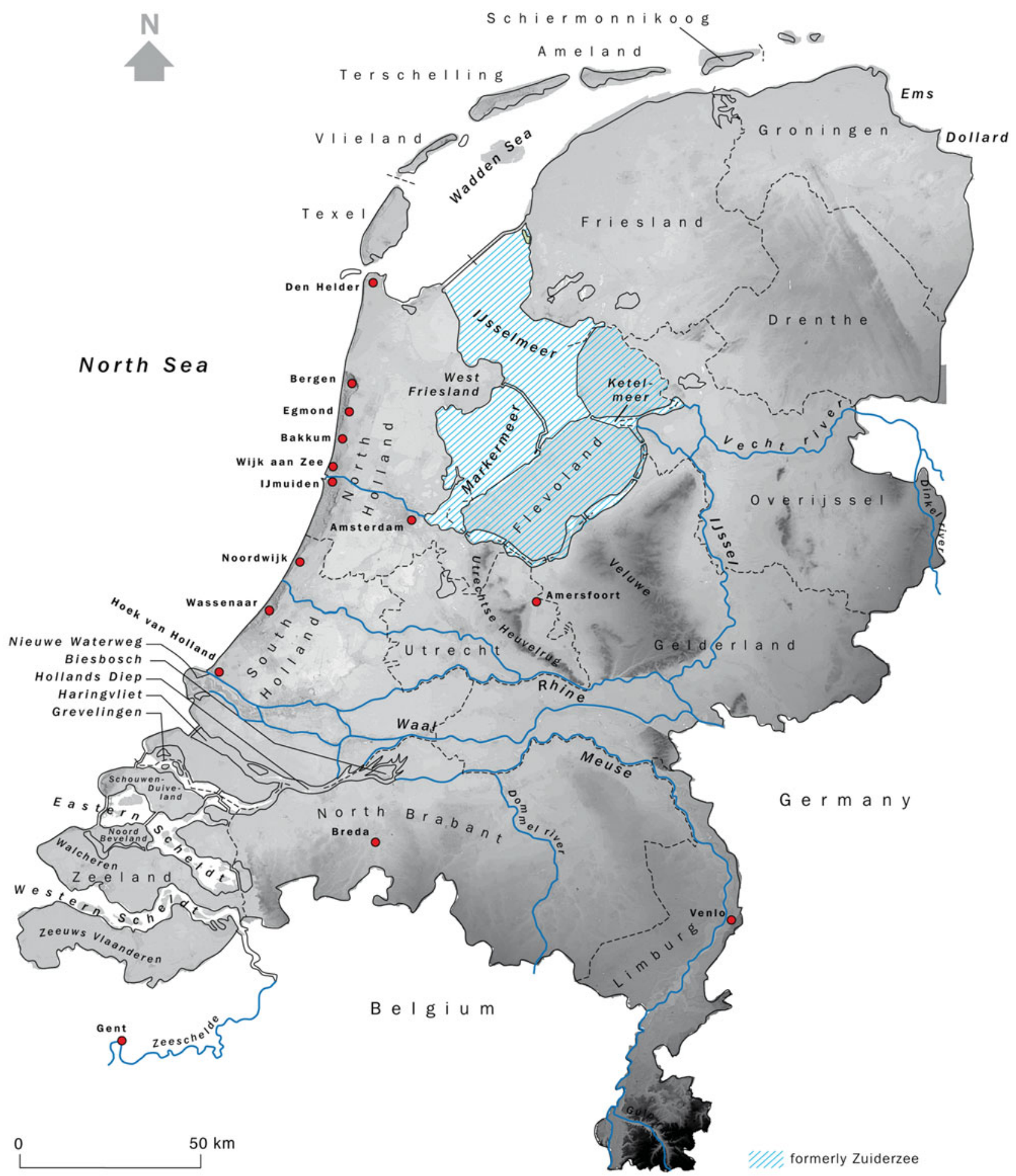

Fig. 1. The Netherlands, showing the topography and the locations of the geographical names referred to in this paper.

2 Geoscientific characteristics of the

\section{Netherlands}

\subsection{Geological history}

The Netherlands lies on part of the lowlands bordering the southern part of the North Sea. Geologically, the area has evolved largely from sedimentary processes in a deltaic setting at the lower end of major river systems draining into the southern North Sea (Fig. 2). Tectonically, the Netherlands is part of the subsiding North Sea Basin. It is bounded in the southeast by the Palaeozoic rocks of the Ardennes and Eifel, and continues to the east in the plains of North Germany and Poland. The main tectonic structure of the subsurface is situated in the southeast 


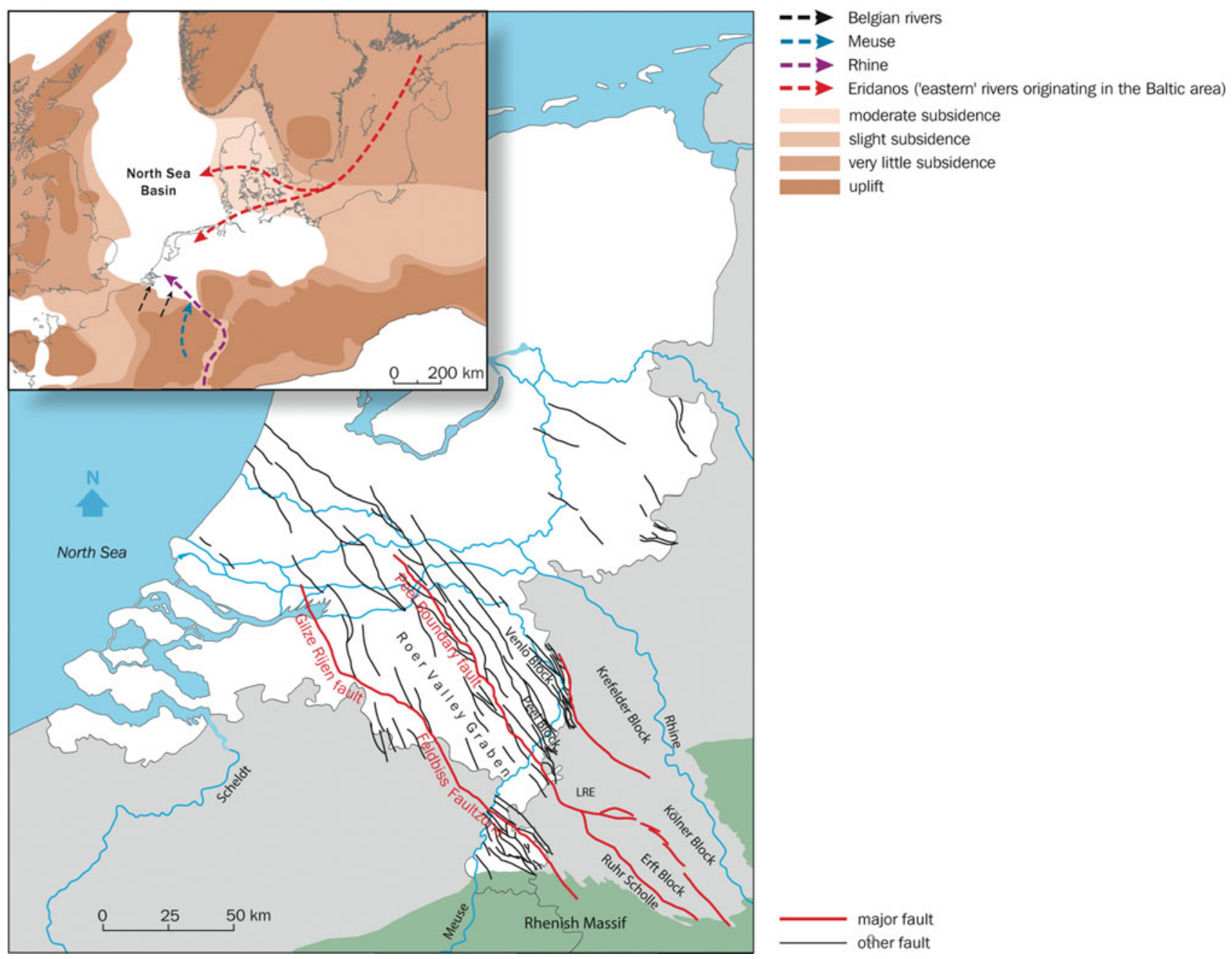

Fig. 2. Geological settings of the Netherlands during the Quaternary (upper left) and its main, shallow tectonic structures.

of the country, where major fault zones trending southeast to northwest border the subsiding Roer Valley Graben and the adjacent Peel Block. The latter is strongly dissected by a complex pattern of faults (Van Balen et al., 2005).

During most of the Cenozoic (the last 65 million year of the Earth's history), the area was under shallow seas in which fine-grained sediment was deposited. Generally these shallow marine deposits show a trend of decreasing mean grain size towards the centre of the North Sea Basin, while at the margins fine- to medium-grained sand prevails. These sediments may have a characteristic green colour, which results from their glauconite content.

Local and regional uplift in the surrounding areas from about 10 million years ago brought about fluvial systems draining to the southern North Sea Basin. Large quantities of sediment were supplied to the North Sea Basin by these rivers, forming huge delta systems that gradually prograded westwards and northwestwards. By the time of the Mid-Pliocene (c. 3 million years ago), the coastline roughly followed the southern and eastern borders of the present territory of the Netherlands. Thereafter the coastline gradually shifted northwest, and in the course of the Early Pleistocene (about 1.5 million years ago) fluvial sedimentation dominated the entire part of the country that is now onshore. The sediment was supplied by four main river systems: the Rhine, the Meuse, the rivers draining the central and northern part of Belgium, and the Eridanos fluvial system (a major drainage system originating in the Baltic area). The Rhine, Meuse and Belgian rivers dominated the sedimentation in the southern and central part of the Netherlands. The Eridanos supplied sediment to the northern part of the country.

As a result of long-term fluvial-deltaic processes in a subsiding basin, the upper $200 \mathrm{~m}$ of the subsurface of the Netherlands consists of complex interdigitated marine and deltaic deposits overlain by a series of stacked fluvial deposits. In the northern and central part of the country this complex pattern of stacked marine and fluvial deposits was interrupted at least twice by major advances of ice sheets during Elsterian and Saalian glacial phases in the upper part of the Pleistocene. For additional 
information on the geological history of the Netherlands see De Mulder et al. (2003), Wong et al. (2007), Weerts et al. (2005), Westerhoff (2009) and Knox et al.(2010).

\subsection{Geography and hydrology}

Geographically as well as geologically, the landscape of the Netherlands can be subdivided into two major domains. The coastal and alluvial lowlands form the rather flat and low-lying western and northern parts of the country (Fig. 1). This area is covered by a seaward thickening wedge of Holocene tidal and fluvial deposits (Fig. 3), which serve as a confined, semipermeable cover on top of coarser-grained Pleistocene deposits. Generally, the elevation of the coastal plain is at or slightly above mean sea level, but in the reclaimed areas (polders) the ground level may be several metres below that level. Surface water is pumped out of the polders and groundwater recharge happens by infiltration of rain, seawater and surface water (lakes and also ditches or canals in those polders that have a relatively higher altitude). Recharge of the aquifers from relatively high-lying polders is $30-100 \mathrm{~mm} / \mathrm{y}$ (NHV, 2004). Groundwater within $30 \mathrm{~m}$ depth is usually $\mathrm{pH}$-neutral and anaerobic, and varies from fresh to saline (Griffioen et al., 2013). The conditions for weathering of the aquifer sediments are thus generally unfavourable. A complex of dunes and barriers lies along the entire Dutch coast, with a maximum height of $55 \mathrm{~m}$ above sea level. The fresh groundwater belt in the dunes is a major source of recharge for the adjacent low-lying polders and is nowadays used for aquifer storage and recovery of drinking water. Tidal estuaries typify the southwestern part of the coast, while extensive tidal flats and barrier islands characterise the northern coastline.

Outside South Limburg, the rest of the country is often referred to as the 'Pleistocene' part of the country (Fig. 3). The terrain is smoothly undulating, with the surface mainly comprising sandy deposits formed during the Pleistocene Epoch and well-developed aquifers below. In the centre and east of the country, low hills formed as ice-pushed ridges some 150,000 years ago, when the northern half of the country was covered by a major ice sheet. The northern part of the country is an extensive flat area with basal till ('keileem') at or near the surface. The till area is regionally poorly drained and as a result, extensive peat formation occurred. However, most of the peat was excavated for fuel in the 19th and 20th centuries. Generally, groundwater is regionally discharged through a natural drainage system of small-scale rivers and brooks, although many groundwater abstractions are also present nowadays. A thin veneer of Holocene alluvial deposits may occur in the associated valley systems. Groundwater recharge is around 350 $\mathrm{mm} / \mathrm{y}$ but lower under pine forest; the ice-pushed ridges act as major regional recharge areas when sandy. Shallow groundwater (<30 $\mathrm{m}$ depth) in the Pleistocene area is usually fresh, suboxic to anaerobic and acid to pH-neutral (Fest et al., 2007; Griffioen et al., 2013). In the Pleistocene part of the Netherlands, leaching of the aquifers sediments is thus a feasible process at the geological time scale.

Mesozoic marls are outcropping in a small area of the Achterhoek in the eastern part of the country. A totally different landscape occurs in South Limburg, characterised by a more pronounced morphology of hills and incised valleys, with the highest elevation (322 $\mathrm{m}$ above sea level) at the Vaalserberg. Loess formed during the Middle and Late Pleistocene glacial periods forms here a veneer overlying Cretaceous and Paleogene and Neogene clastic marine and fluvial deposits. A sequence of Pliocene and Quaternary river terraces mainly consisting of coarse gravel marks the former course of the Meuse in the area. Groundwater is naturally recharged, typically fresh, frequently nitrate-rich and $\mathrm{pH}$-neutral to slightly allkaline at shallow depth (Vermooten et al., 2007). The latter is due to the omnipresence of Ca carbonates.

The North Sea is an epicontinental sea with water depths of less than $30 \mathrm{~m}$ in the south to about $200 \mathrm{~m}$ in the north (0tto et al., 1990). Deeper water, up to $700 \mathrm{~m}$, is restricted to Norwegian Trench and the Skagerrak far in the northeastern part of the North Sea. There is an anticlockwise rotating tidal and residual current system resulting in deposition of suspended matter in the estuaries, tidal flat areas near the Frisian Isles, the German Bight, the Skagerrak, Norwegian Channel and the Kattegat. The Frisian Front northwest of the Dutch Wadden island of Terschelling also acts as a temporary deposition area due to slow currents on average. The bottom of the shallow, southern part of the North Sea predominantly consists of sand stored in sand waves which is largely re-worked from fluvial deposits that were formed during extensive periods of low sea level during glacial phases. Most of the primary biological production takes place in the shallow unstratified southern part of the North Sea (Dauwe \& Middelburg, 1998).

\subsection{Lithostratigraphy and geological formations}

2.3.1 Lithostratigraphy. Coherent and mappable bodies of rock or sediment layers have been classified in the lithostratigraphical system of the Geological Survey of the Netherlands. In fact, lithostratigraphy is the classification of bodies of rock based on the observable lithological properties of strata and their relative stratigraphical positions (Salvador, 1994; Westerhoff \& Weerts, 2013). Lithostratigraphy serves to unravel the seemingly chaotic composition of the subsurface into geometrically (3D) defined units of more or less similar characteristics. It is a useful tool for showing the interrelationships of the discerned units. The central unit of the lithostratigraphical system applied here is the formation. Except for the lowermost marl deposits all Cenozoic formations are grouped in the so-called North Sea Group. Formations can be subdivided into members or beds (the lowest rank in the stratigraphical hierarchy). However, not all parts of a formation need to be 


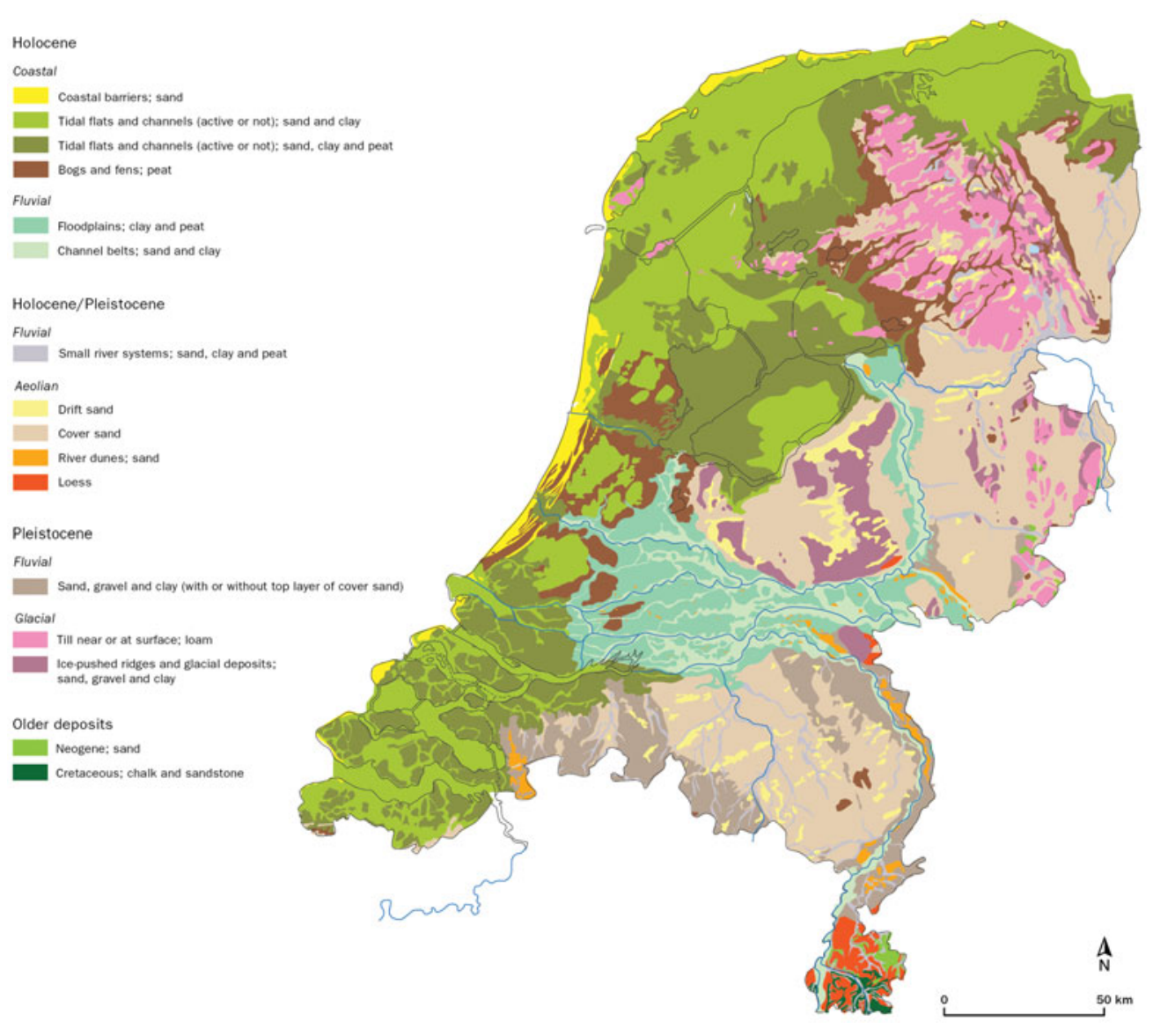

Fig. 3. Surface geology of the Netherlands.

subdivided into members or beds. In such cases the formation or a part of it is undifferentiated.In this review we deal with mainly surficial and shallow (up to a depth of few hundred metres) mostly unconsolidated Cenozoic deposits, which are found in most of the Netherlands. The lithostratigraphical subdivision of these Cenozoic deposits is summarised in Fig. 4. The various units are listed according to their geological age alongside the vertical. A striking modification with respect to a substantial part of the literature reviewed here is that the term Tertiary is no longer used. Instead, two periods, the older Paleogene and younger Neogene, now divide the Cenozoic time below the Quaternary. The lithostratigraphy of the Paleogene period follows the nomenclature published by Van Adrichem Boogaert and Kouwe (1997), De Mulder et al. (2003) and Wong et al. (2007). The lithostratigraphy of the Neogene and Quaternary periods is in accordance with De Mulder et al. (2003) and Weerts et al. (2005). Both nomenclatures are found on DINOloket, the data and information site of the Geological Survey of the Netherlands (https://www.dinoloket.nl/nomenclator). Repeatedly, reference is made to members that are part of the geological formations. An overview of all members referred to is provided in Table 1.

The literature reviewed and cited in this study repeatedly refers to the lithostratigraphical nomenclature published in the 1970s (Doppert et al., 1975), which was drastically revised in 2003 (Ebbing et al., 2003; Weerts et al., 2005; Westerhoff, 2009). The various Neogene and Quaternary lithostratigraphical units (Fig. 4) have now been categorised according to their genesis (i.e. marine, fluvial, glacial and deposits of mainly local or reworked origin) and the provenance of the sediment (i.e. Rhine, Meuse, Baltic area).

2.3.2 Paleogene deposits. Paleogene sediments are almost entirely marine. The lowermost, calcareous Paleogene sediments consist of soft fine- to coarse-grained marls and have been assigned to the Houthem Formation. The distribution is restricted to the southeast of North Brabant and Limburg. The formation forms part of the Cretaceous Chalk Group (Van Adrichem Boogaert \& Kouwe, 1997).

All deposits younger than this formation form part of the North Sea Group, the basal part of which is formed by the Landen Formation. This formation consists of fine sand and clay, or a mixture of both, which was deposited in a shallow marine environment along the southern margins of the North Sea Basin.

The Dongen Formation is characterised by a sharp basal contact and consists of thick layers of stiff clay alternating with green glauconitic sand in the marginal areas. Towards the centre of the North Sea Basin the sand deposits grade into clay 


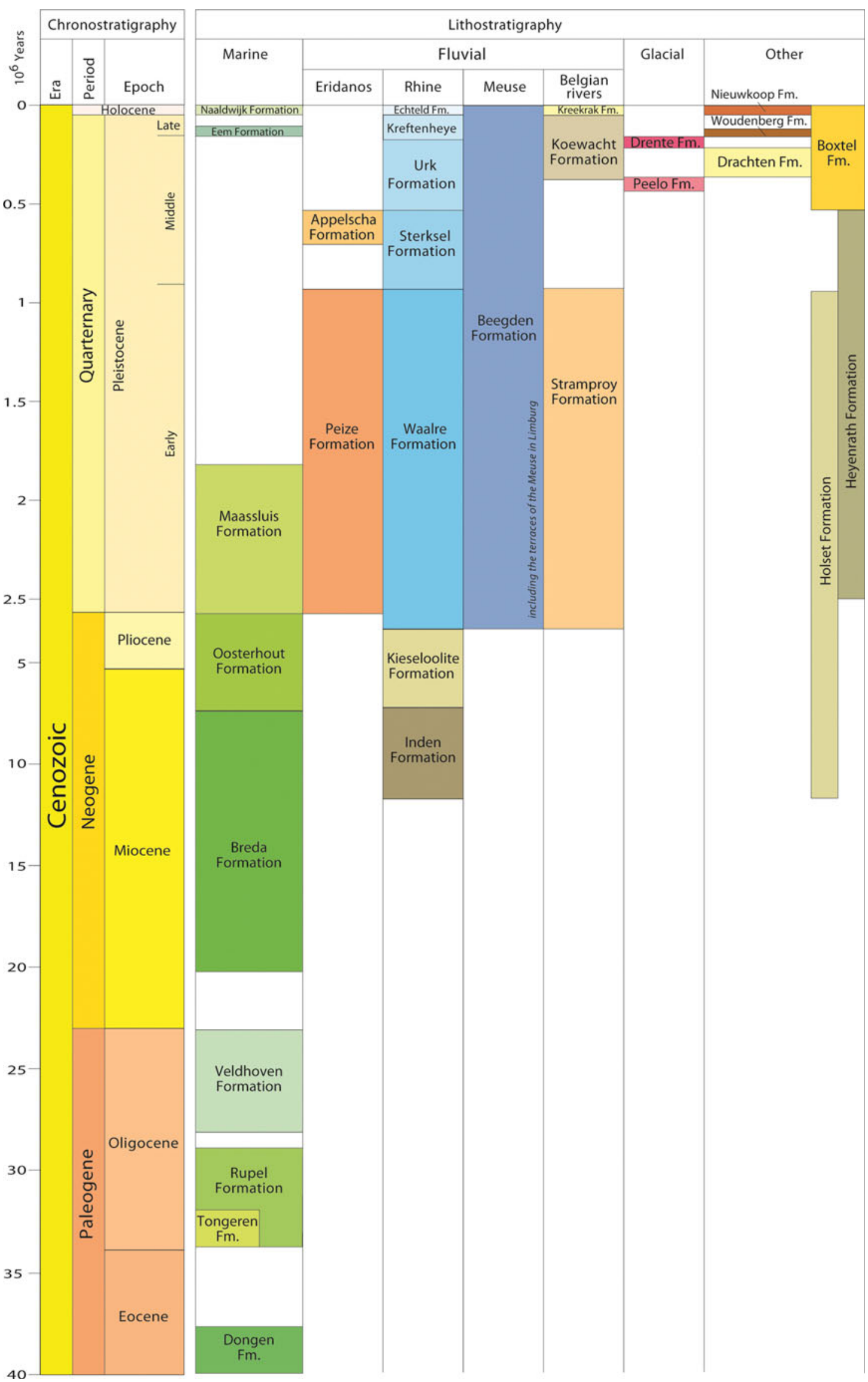

Fig. 4. Lithostratigraphy of Cenozoic deposits in the Netherlands. 
Table 1. Overview of the lithostratigraphical members mentioned in the subsequent sections of this manuscript, arranged according to the formations to which they belong, and some main lithological characteristics.

\begin{tabular}{|c|c|c|}
\hline Formation & Member & Main characteristics \\
\hline \multirow{4}{*}{$\begin{array}{l}\text { NAALDWIJK } \\
\text { (Holocene, coastal } \\
\text { plain deposits) }\end{array}$} & Schoorl & $\begin{array}{l}\text { Coastal dune deposits bordering the North Sea Coast; medium-grained } \\
\text { sand ranging from rich in carbonate to carbonate-free. }\end{array}$ \\
\hline & Zandvoort & $\begin{array}{l}\text { Beach barrier deposits, medium grained sands with locally abundant shell } \\
\text { fragments. }\end{array}$ \\
\hline & Walcheren & $\begin{array}{l}\text { Tidal deposits on top of the Holland peat; the lithology ranges from sand to } \\
\text { clay deposited in channel, mud-, sand flat, or salt marshes. }\end{array}$ \\
\hline & Wormer & $\begin{array}{l}\text { Tidal deposits in between the basal peat and Holland peat; the lithology } \\
\text { ranges from sand to clay deposited in channel, mud-, sand flat, or salt } \\
\text { marshes. }\end{array}$ \\
\hline \multirow{4}{*}{$\begin{array}{l}\text { BOXTEL } \\
\text { (deposits of local origin } \\
\text { and small brooklets, } \\
\text { Mid Pleistocene to } \\
\text { Early Holocene) }\end{array}$} & Liempde & $\begin{array}{l}\text { Mixture of loess and reworked loess mainly formed in wet periglacial envi- } \\
\text { ronments and found only in the Roer Valley Graben. }\end{array}$ \\
\hline & Tilligte & $\begin{array}{l}\text { Fine-grained loam and sand often containing organic matter, formed under } \\
\text { periglacial conditions. Their occurrence is restricted to the glacial basins in } \\
\text { the eastern part of the Netherlands, where it forms the lower part of the } \\
\text { formation. }\end{array}$ \\
\hline & Schimmert & $\begin{array}{l}\text { Loess deposits, fine-grained loam deposited during glacial phases and } \\
\text { predominantly found in the hilly landscape of South Limburg. }\end{array}$ \\
\hline & Wierden & $\begin{array}{l}\text { Fine to medium grained aeolian sand known as cover sand and deposited in } \\
\text { a periglacial environment. }\end{array}$ \\
\hline $\begin{array}{c}\text { KREFTENHEIJE } \\
\text { en BEEGDEN } \\
\text { (Late Pleistocene fluvial } \\
\text { deposits, Rhine and Meuse) }\end{array}$ & Wijchen & $\begin{array}{l}\text { A compact clay containing fine-grained sand and silt that is formed on top } \\
\text { of fluvial deposits at the end of the Weichselian glacial time. Occurs mainly } \\
\text { in Limburg and in the central part of the Netherlands. }\end{array}$ \\
\hline \multirow{2}{*}{$\begin{array}{l}\text { DRENTE } \\
\text { (Mid Pleistocene } \\
\text { glacial deposits) }\end{array}$} & Gieten & $\begin{array}{l}\text { A compact diamicton of poorly sorted clay/loam, gravel, stones, cobbles, } \\
\text { and boulders deposited as glacial till. in Dutch referred to as 'keileem'. }\end{array}$ \\
\hline & Uitdam & Glaciolacustrine sand and silty clay deposited in deep glacial basins. \\
\hline $\begin{array}{l}\text { PEELO } \\
\text { (Mid Pleistocene } \\
\text { glacial deposits) }\end{array}$ & Nieuwolda & $\begin{array}{l}\text { Stiff silty or sandy clay often rich in carbonate formed as glaciolacustrine de- } \\
\text { posits their occurrence is bound to the infilling of subglacial tunnel valleys } \\
\text { tunnel valleys. In Dutch referred to as 'Potklei'. }\end{array}$ \\
\hline \multirow{2}{*}{$\begin{array}{l}\text { URK } \\
\text { (Mid Pleistocene fluvial } \\
\text { deposits, Rhine-Meuse) }\end{array}$} & Tynje & $\begin{array}{l}\text { Coarse sand containing some gravel and locally clay layers. It is by definition } \\
\text { only recognised when it overlies the Peelo Formation }\end{array}$ \\
\hline & Veenhuizen & $\begin{array}{l}\text { Coarse sand and some gravel that by definition is only discerned when it } \\
\text { underlies the Peelo Formation. }\end{array}$ \\
\hline $\begin{array}{l}\text { APPELSCHA } \\
\text { (Mid Pleistocene fluvial } \\
\text { deposits, Eridanos) }\end{array}$ & Weerdinge & $\begin{array}{l}\text { Coarse sand found in the eastern Netherlands with a relatively high contri- } \\
\text { bution of topaz in the heavy mineral fraction. }\end{array}$ \\
\hline $\begin{array}{l}\text { KIESELOOLITE } \\
\text { (Mio/Pliocene, pre-Rhine) }\end{array}$ & Reuver & $\begin{array}{l}\text { Clay with locally intercalated lignite layers and found in the upper part of } \\
\text { formation. }\end{array}$ \\
\hline $\begin{array}{l}\text { BREDA } \\
\text { (Miocene, marine) }\end{array}$ & Heksenberg & $\begin{array}{l}\text { Extremely quartz rich sand which is referred to as 'silver sand'(silica sand) } \\
\text { deposited in a near shore to beach environment. }\end{array}$ \\
\hline $\begin{array}{l}\text { RUPEL } \\
\text { (Oligocene, marine) }\end{array}$ & Rupel Clay & $\begin{array}{l}\text { Very stiff, silty clay, often humic, locally with high concentrations of pyrite } \\
\text { and carbonate/siderite concretions (septarian). }\end{array}$ \\
\hline
\end{tabular}

and clayey marls. The basal layer consists of a tuffaceous clay. The formation is of Eocene age. Regional uplift and inversion took place during the Pyrenean tectonic phase after deposition of the Dongen Formation and resulted in a hiatus in the upper part of the Eocene. Subsequently, the tectonic regime changed, and renewed subsidence took place during the Oligocene. It is noteworthy that the Roer Valley Graben has accommodated some $1200 \mathrm{~m}$ of sediment since the Late Oligocene, yet over 
the same period the adjacent Peel Block subsided by only some $200 \mathrm{~m}$. Deposits of the Tongeren Formation occur only in South Limburg.

The Rupel Formation mainly consists of dark silt containing clay. The formation is subdivided into three main members. The lowermost one has been assigned as the Vessem Member and consists of fine-grained glauconitic sand. This member is up to $30 \mathrm{~m}$ thick and occurs mainly in the south of the Netherlands. It is overlain by the Rupel Clay Member, a dark brown to grey stiff clay with a relatively high silt content. The clay is up to $160 \mathrm{~m}$ thick and is absent in parts of South Limburg and in some areas along the eastern border of the country. In Zeeuws-Vlaanderen and parts of the Achterhoek, the upper part of the Rupel Clay Member occurs near to the surface. Although lithostratigraphically not identical, the Rupel Clay Member can be correlated with the well-known Boom Clay in Belgium, which has been studied intensively on its mineralogical composition. In this study we will refer to the deposit as Rupel Clay when we are discussing data and interpretations of the clay in the Netherlands. Conversely, we will speak of Boom Clay when dealing with information from Belgium.

The Veldhoven Formation is well developed in the Roer Valley Graben, where it is about $400 \mathrm{~m}$ thick. The distribution area is restricted to the Roer Vally Graben, the adjacent Peel Block and the southeastern part of the Zuiderzee Low. Tectonic activity caused regional uplift and inversion at the end of the Paleogene. Concurrently, the climate became cooler and sea level dropped some $60 \mathrm{~m}$ at the end of the Oligocene. The combined effect of these three factors resulted in a depositional hiatus at the Oligocene-Miocene transition.

2.3.3 Neogene and Quaternary deposits. Subsidence in the North Sea Basin prevailed during the Neogene and Quaternary periods, enabling huge amounts of sediment supplied by the major river systems to be accommodated. The basin became filled along its margins, and a gradual but continuing shift of the coastline westwards and northwestwards resulted from the prograding fluvial systems.

2.3.3.1 Marine deposits. In the present onshore part of the Dutch territory, five marine formations are discerned within the Neogene-Quaternary sequence. They are briefly described here; for more details, see the nomenclature (https://www.dinoloket.nl/nomenclator). The Breda Formation consists of marine glauconitic fine sand and silty clay, and was deposited during the Miocene. The formation occurs everywhere in the subsurface, except in a zone parallel to the eastern border. Extremely quartz-rich sand (silica sand) occurs in South Limburg and in parts of the Roer Valley Graben: it is situated in between two layers of lignite. In the west of North Brabant, deposits very rich in glauconite (up to 70\%) have been assigned to the Rucphen Member. Going south to north in the basin, the deposits of the Breda Formation tend to become finer-grained and their clay content increases.
Deposits of the Oosterhout Formation overlie the Breda Formation, and they consist mainly of fine- to medium-grained sand, clay and sand with abundant shell remains. The glauconite content is considerably lower than in the Breda Formation. The lower boundary is sharp in the southwestern part of the country but gradual elsewhere. Extremely shell-rich deposits (crags) occur in the west of North Brabant and have been assigned to the Sprundel Member. In the same region, a brown clay deposit marks the upper part of the formation and has been assigned to the Wouw Member. The formation is Pliocene in age and its offshore equivalent is called the Brielle Ground Formation.

The Maassluis Formation consists of fine- to coarse-grained shell-bearing sand sometimes alternating with layers of clay. The transition to the underlying 0osterhout Formation is gradual and difficult to define in the western and northern parts of the country. At the eastern and southeastern limits of its distribution, the deposits interdigitate with fluvial sediments of the Eridanos (i.e. the major rivier system that originated in the Baltic region and existed from Eocene to Middle Pleistocene; Overeem et al., 2001) or Rhine-Meuse river systems. The Maassluis Formation was formed during the first part of the Pleistocene.

At the end of the Early Pleistocene the marine realm had migrated to positions west of the present coastline of the Netherlands. This situation persisted for a long time, and not until the Saalian land ice cover had melted could the sea again transgress over the western part of the country. Fine- to coarse-grained shell-bearing sand and clay deposits formed during that marine phase have been assigned to the Eem Formation. Thick marine clay deposits may occur in the glacial basins formed during the Saalian advance of major ice sheets.

The uppermost marine deposits were formed during the Holocene transgression when the sea invaded the western and northern parts of the Netherlands and they have been assigned to the Naaldwijk Formation. This formation consists of interrelated estuarine, tidal and coastal deposits forming a seaward thickening wedge of sediment in the coastal plain. The lithological composition varies from fine- to medium-grained sand and clay deposited in mudflats, salt marshes and tidal lagoons. Along the present coastline the wedge of Holocene coastal deposits is bordered by thick accumulations of sand stored in natural barriers and coastal dunes.

2.3.3.2 Fluvial deposits. The geological evolution of the Neogene and Quaternary is characterised by the formation of huge deltaic systems, the uppermost sets of which consist of coarsegrained fluvial deposits. The latter may be up to $200 \mathrm{~m}$ thick in the onshore part of the Netherlands. The fluvial deposits are categorised into three major groups reflecting their source areas: the Rhine, Meuse and Eastern river systems (Baltic area). Smaller systems are recognised related to rivers draining central and north Belgium, including the Scheldt. There are 13 fluvial formations in total. During most of the Pliocene and 
Pleistocene the Netherlands was situated downstream of the confluence of Rhine and Meuse (Westerhoff et al., 2008). Consequently the sediment has a mixed Rhine-Meuse composition. However, being the larger river the Rhine overprints nearly all sedimentary and mineralogical properties of these mixed deposits. The provenance of Meuse can only be identified in very coarse-grained components, such as gravel, stones and boulders derived from rocks in the Ardennes and northern France.

Rhine-Meuse The first fluvial sediments formed in the Netherlands were deposited by a predecessor of the river Rhine system. This pre-Rhine had no connection with the Alpine area and its source material consisted of the strongly weathered overburden of the Rhenish Massif (Boenigk, 2002; Schäfer et al., 2005; Westerhoff et al., 2008). As a result, the deposits of the pre-Rhine system are typified by a high percentage of quartz and the mineralogical composition is dominated by so-called stable heavy minerals such as tourmaline, staurolite and some metamorphic minerals. The deposits of the pre-Rhine system have been assigned to the lower situated Inden Formation and the overlying Kieseloolite Formation. The Inden Formation consists of medium- to coarse-grained grey sand with multiple remains of wood and lignite, and was formed during the Late Miocene. It occurs only in the southeastern part of the Roer Valley Graben. The Kieseloolite Formation consists of pale sand and gravel alternating with some local to regional clay layers. The latter often contain layers of brown coal or lignite. The unit is Late Miocene to Pliocene in age and is found on the Peel Block, Roer Valley Graben and parts of South Limburg.

As a result of the progressive enlargement of the pre-Rhine drainage basin towards southern Germany and the Alpine region, new source areas of metamorphic and crystalline rocks became available to the Rhine system during the second half of the Pliocene. Evidence for this in the sediments is the presence of mica flakes, an increase in red-brown particles (i.e. feldspar and sandstone) and a decreasing quartz content. However, most striking is the major shift in the heavy mineral composition: from nearly $90 \%$ predominance of stable heavy minerals (known from the Inden and Kieseloolite Formations) to a nearly $90 \%$ predominance of so-called unstable heavy mineral assemblages. The latter consist of minerals such as garnet, epidote, alterite/saussurite and hornblende (Boenigk, 2002; Westerhoff, 2011).

The earliest deposits of the enlarged Rhine system have been assigned to the Waalre Formation and consist of fine- to coarsegrained grey sand alternating with clay layers up to several metres thick. The Waalre Formation was deposited during the Late Pliocene and Early Pleistocene. Due to the tectonic setting the upper part of the formation inclines towards the northwest. The Sterksel Formation is easily recognisable from its coarsegrained gravel-bearing basal part and stratigraphical situation above the Waalre Formation. Clay layers in the Sterksel Forma- tion occur only locally. The relatively large amount of coarse material of the Sterksel Formation may result from accelerated uplift of the Rhenish Massif, which occurred at the onset of the Mid-Pleistocene (Garcia-Castellanos et al., 2000). The formation was deposited during the latest part of the Early Pleistocene and the earliest part of the Mid-Pleistocene.

The uppermost three formations of the Rhine system are mineralogically characterised by a relatively high content of volcanic minerals, mainly augite, resulting from renewed volcanism in the Eifel region. The Urk Formation is a typical fine- to coarse-grained Rhine sediment, with a low gravel content and near absence of clay layers. It occurs in the central and northern parts of the country and was formed during the second half of the Mid-Pleistocene. It is overlain by the Kreftenheye Formation, a mixed Rhine-Meuse deposit covering the centre of the Netherlands. The lithology ranges from fine- to coarsegrained sand and some gravel. Locally, clay layers may be intercalated. In the central river district of the country, a typical silt-containing and compact grey clay layer occurs at the top of the formation. The layer has been lithostratigraphically assigned to the Wijchen Bed. The stratigraphically uppermost and youngest fluvial deposits in the Netherlands are known as the Echteld Formation. This is a mixed Rhine-Meuse deposit whose formation was strongly influenced by the Holocene sea-level rise. The meandering to anastomosing system supplied sediment consisting of fine- to medium-grained sand that was mainly deposited in channels and on levees. Grey to brown clay with plant and wood remains was deposited in extensive flood basins.

Meuse All the pure Meuse deposits in the Netherlands have been assigned to the Beegden Formation. Generally, the deposits consist of medium- to coarse-grained sand and coarse gravel, stones, cobbles and boulders. Locally, clay layers with a limited lateral distribution may occur. More widespread is the silt-containing compact clay layer present at the top of the Late Weichselian fluvial deposits in north and central Limburg. This is the so-called Wijchen Bed that continues into the Kreftenheye Formation. Deposited by the Meuse, all fluvial terrace deposits in South Limburg form part of the Beegden Formation. The oldest terraces date from as far back as the Pliocene.

Eastern river systems Sediment of eastern provenance was supplied by the so-called Eridanos river system that originated in the Baltic area (Overeem \& Kroonenberg, 2002). The deposits have been assigned to the Peize Formation and consist of pale medium- to coarse-grained sand, rich in quartz, and some gravel. Some clay layers may occur, especially in the lower part of the unit. In the uppermost part of the formation, coarse gravel of Baltic provenance may occur locally: the so-called Hattem beds (Zandstra, 1971). The formation covers the northern half of the Netherlands, is up to $150 \mathrm{~m}$ thick and interdigitates with the Waalre Formation in the central part of the country. The age ranges from Late Pliocene to Early Pleistocene. 
The Appelscha Formation is the second unit of fluvial deposits of eastern provenance. However, most of the sediment originates from rivers draining North Germany and the Mittelgebirge. The sediment consists of medium- to very coarsegrained grey-white sand and gravel. The formation has a continuous distribution in the northern half of the country and some patchy occurrences in the eastern part of 0verijssel. The deposits date from the latest part of the Early Pleistocene to the earliest part of the Mid-Pleistocene.

The Quaternary glaciations finally destroyed the hydrogeographical patterns in northern Europe and probably also destroyed the upper reaches of the Baltic river system. As a result, the supply of sediment from the Baltic region and the Mittelgebirge to the Netherlands ceased.

Belgian rivers During the Late Pliocene and entire Early Pleistocene, the central and northern part of Belgium was drained by a series of rivers flowing northeast, which supplied fine- to medium-grained pale sand to the southern part of the Netherlands. Their deposits have been assigned to the Stramproy Formation. The sediment is rich in quartz and the heavy minerals are predominately stable assemblages. Clay layers are only 1-2 $\mathrm{m}$ thick in the southern part of the distribution area but may be several metres thick in the more westerly areas. Deposits of the Stramproy Formation interdigitate with the Waalre Formation in the Roer Valley Graben and the area west of it. Furthermore, deposits of the Stramproy Formation overlie the Waalre Formation in large parts of the southern and western Netherlands.

Regional tectonics and the development of west to east running cuestas during the Middle Pleistocene caused a restructure of the drainage pattern of the rivers in northern Belgium. The rivers changed their northeastern running courses to western ones and became confluent with the Scheldt River. Fluvial deposits of this Scheldt system consist of fine- to moderategrained sand and are found in the southwestern part of the Netherlands and assigned to the Koewacht Formation. The Koewacht Formation was formed during the Middle Pleistocene. Holocene deposits of the Scheldt consist of fine-grained sediment very rich in organic matter (peat and gyttja) that is found in the paleovalley of the Scheldt in the southwestern part of the coastal plain. These specific deposits are assigned to the Kreekrak Formation.

2.3.3.3 Glacial deposits. The Quaternary sequence of marine and fluvial deposits in the Netherlands was interrupted at least twice by a major southward advance of the Scandinavian ice sheets. The first time was during the Elsterian glaciation some 400,000 years ago. The glacial deposits formed during this period have been assigned to the Peelo Formation, which occurs only in the northern part of the country and consists of fineto coarse-grained sand and stiff dark brown clay. The sand is a meltwater deposit partly formed in deeply incised (more than
$500 \mathrm{~m}$ !) tunnel valleys in which clay is often the uppermost part of the sedimentary infill. The clay is often described as 'Potklei' and nowadays lithostratigraphically assigned as the Nieuwolda Member of the Peelo Formation.

Glacial deposits formed during the Saalian ice coverage of the Netherlands all form part of the Drente Formation. The ice sheet extended to approximately the imaginary AmsterdamNijmegen line, and at its margins ice-pushed ridges and glacial basin were formed. Three main lithostratigraphical units subdivide the Drente Formation, two of which will be considered in this manuscript (Gieten and Uitdam Members; Table 1). The third unit is the Schaarsbergen Member, which is composed of fine- to coarse-grained sand and gravel formed as glacio-fluvial meltwater deposits and sandr-type deposits.

2.3.3.4 Other deposits. A separate category of lithostratigraphical units consists of material resulting from intense weathering, aeolian deposits, sediment formed by small-scale fluvial systems, and large-scale peat formation in extensive swamps, coastal plains and alluvial floodplains. Three units consisting entirely of peat are discerned in the Neogene-Quaternary sequence. The lowermost is called the Ville Formation (Schäfer et al., 2005): it is the main brown coal formation in the lower Rhine Embayment. Two wedges of the Ville Formation extending westwards reach the Netherlands and are situated below and above the well-known silica sand of the Heksenberg Member in South Limburg.

Peat formed in the Eemian coastal plain has been assigned to the Woudenberg Formation and occurs mainly in a zone bordering the marine Eem Formation in the Gelderse Vallei, a former glacial basin. Extensive Holocene peat formation occurred in the coastal plain, the fluvial district and in regionally poorly drained areas such as the till-dominated region in the northern Netherlands. All these peat accumulations have been assigned to the Nieuwkoop Formation. It is worth noting that very local and non-mapable peat accumulations that may have formed in a flood basin or a local dune valley are not classified as part of one of these main peat formations. Instead, the peat layers are interpreted as local phenomena and genetically related to the general lithological composition of a formation.

The Holset Formation consists of fine-grained sand and blocks of sandstone resulting from early diagenesis. The formation occurs only in South Limburg and exclusively in areas not covered by Pliocene and Pleistocene fluvial deposits. The distribution of the Heyenrath Formation is also restricted to South Limburg. The deposits consist of weathered flint in a matrix of clay and result from weathering of the underlying chalk. They have an irregular patchy distribution and the thickest accumulations occur in karst cavities like 'organ pipes'.

The most important group of deposits in this category is formed by the Boxtel Formation (Schokker et al., 2007). It consists of fine- to medium-grained sand, clayey loam and locally formed gyttja. The deposits result mainly from aeolian processes or small-scale fluvial activity under changing or cool 
climatic conditions. The age ranges from Mid-Pleistocene to Holocene. The deposits of the Boxtel Formation cover almost the entire country except for the fluvial district and the coastal plain, where they have been removed by tidal erosion during the Holocene. Nine members are discerned within the Boxtel Formation, four of which (Liempde, Schimmert, Tilligte and Wierden) will be considered in this manuscript because there is specific data available for these members (Table 1). It is worth noting that a large part of the Boxtel Formation has not been subdivided into separate members. This mainly concerns sediment formed by small-scale fluvial systems under periglacial conditions.

\section{Review procedure and methodological approaches}

This section covers a few general topics. First, we present the general procedures we followed when carrying out this review and describe how we delimited the scope of the review. Second, we discuss the methodological approaches used to characterise Dutch sediments by their mineralogy and grain size distribution. It is important to summarise these approaches because this makes it easier to understand the insights presented in subsequent sections and in the original literature. Third and last, we present Table 2 in which we briefly describe the types of organic compounds and plankton groups as discussed in the organic geochemistry sections of the current review. This should serve the reader who is not very familiar with organic geochemistry. Further, we will refer to $0 \mathrm{M}$ when discussing bulk organic matter. We use POC exclusively to refer to particulate organic carbon associated with suspended matter.

\subsection{Scope of the review}

Since we intended to summarise direct evidence on the mineralogy of sediments, we focused our review on research that directly studied samples of sediment or suspended matter. We considered peer-reviewed literature (including $\mathrm{PhD}$ theses) as the prime source for individual topics. If we were unable to find any peer-reviewed literature on a topic, we turned to reports by Dutch research institutes, MSc theses or publications in professional Dutch journals.

Over the years, several geological lithostratigraphical units have been defined and used in the Netherlands and therefore older articles sometimes refer to geological formations that are not used in the current lithostratigraphy. When this occurred, we adapted the classification to the present-day one, always striving to avoid ambiguity. This was particularly the case for the Tegelen Formation, which was intensively studied by Huisman and co-workers and is nowadays classified as the Waalre Formation (Huisman et al., 2000; Westerhoff, 2009). In other cases, reference is made to both the former and the present lithostratigraphical unit. An example is the Twente Formation, which became part of the much broader and sedimentologically heterogeneous Boxtel Formation (Schokker, 2003).

We have focused on the natural background mineralogy of Dutch sediments. However, this is almost impossible with respect to recent sediments, largely because the present-day massive hydraulic infrastructure resulting from Dutch water management has probably also affected the mineralogy and geochemistry of sediments deposited in recent centuries. The clearest examples of impact on sediment geochemistry are the closure of the saline Zuiderzee and several estuaries in the southwestern Netherlands, and the subsequent creation of freshwater lakes such as Lake IJsselmeer and Haringvliet. Also relevant are changes in the sediment load of the Rhine and Meuse water systems resulting from canalisation and land use changes (Middelkoop et al., 2010), as well as anthropogenic increases in dissolved major ions such as sulphate (Griffioen et al., 2008). The intensity of sulphide production in association with mineralisation of organic matter is to some extent related to the anthropogenic contamination of surface and groundwater with sulphate. We will characterise the early diagenetic reactions that are associated with the major elements (including $\mathrm{PO}_{4}$ ) and also the impact of regional, palaeohydrological processes on the geochemistry of buried sediments as far as possible. We will not consider the anthropogenic contamination of soil, aquatic sediment and suspended matter with trace metals or organic microcontaminants. Neither do we review the impact of soil chemistry processes related to pedogenesis, except for decalcification, pyrite oxidation and impact of weathering on heavy mineral assemblage. We pay attention to the major organic geochemistry of bulk organic matter (OM) in the riverine and estuarine systems, where - especially in the Scheldt system - there has been severe anthropogenic pollution with organic waste. Our justification is that $\mathrm{OM}$ can be a major reactant in these surface water systems, where it must be remembered that due to pollution the concentration of organic matter may be higher under present-day conditions than was the case in the past under natural conditions.

Recent sediments in large lakes that form an integral part of the Rhine and Meuse water system (in particular Haringvliet, Hollands Diep and Lake IJsselmeer) are discussed in the section on fluvial deposits because their composition is strongly controlled by the sediment load of these major rivers. Lacustrine sediments deposited in other, more isolated lakes will be discussed separately: we will deal with fens in the Pleistocene part of the Netherlands or palaeolakes as mineralogical information is present for these.

\subsection{Grain size distribution}

There is a general relationship between grain size distribution and mineralogy because minerals in clastic sediments have a typical range in grain size related to their hardness (e.g. Boggs, 
Table 2. Description of organic geochemical compounds and types of plankton as mentioned in this manuscript (basically derived from http://www.thefreedictionary.com/ and checked against Engel \& Macko (1993)).

\begin{tabular}{|c|c|}
\hline Compound & Description \\
\hline Carbohydrates & $\begin{array}{l}\text { Any of a large group of organic compounds, including sugars and polysaccharides, that only contain } \mathrm{C}, \mathrm{H} \text { and } 0 \text { with } \\
\text { the general formula } \mathrm{C}_{m}\left(\mathrm{H}_{2} \mathrm{O}\right)_{n} \text { and, more typically, in a 1:2:1 ratio. }\end{array}$ \\
\hline Cellulose & The main constituent of plant cell walls. A polysaccharide consisting of long unbranched chains of linked glucose units. \\
\hline Fatty acids & $\begin{array}{l}\text { Carboxylic acids with a long unbranched aliphatic tail (chain), which is either saturated or unsaturated. Most naturally } \\
\text { occurring fatty acids have a chain with an even number of carbon atoms: from } 4 \text { to } 28 \text {. Naturally occurring fatty acids } \\
\text { are usually derived from triglycerides (esters and main constituent of vegetable oil or animal fat) or phospholipids. }\end{array}$ \\
\hline $\begin{array}{l}\text { Guaiacol, syringol and } \\
\text { their derivatives }\end{array}$ & $\begin{array}{l}\text { Characteristic products of pyrolysis of lignin. The total lignin content varies widely from plant to plant, but it is } \\
\text { estimated that } 30 \% \text { of the organic carbon in plant biomass worldwide is contained in lignin. Lignin-based molecules } \\
\text { exclusively refer to terrestrial organic matter. }\end{array}$ \\
\hline Hopanoids & $\begin{array}{l}\text { Pentacyclic compounds in bacteria whose primary function is to improve plasma membrane fluidity in bacteria. The } \\
\text { related compounds refer exclusively to dead or living bacterial organic matter. }\end{array}$ \\
\hline Lignin & $\begin{array}{l}\text { The major non-carbohydrate constituent of wood, which binds to cellulose fibres and is responsible for the rigidity and } \\
\text { strength of the cell walls and stems of plants. Lignin molecules are derived mainly from three phenylpropane } \\
\text { monomers: } p \text {-coumaryl alcohol, coniferyl alcohol and sinapyl alcohol. }\end{array}$ \\
\hline Lipids & $\begin{array}{l}\text { A broad group of naturally occurring molecules which includes fats, waxes, sterols, fat-soluble vitamins, } \\
\text { monoglycerides, diglycerides and phospholipids. }\end{array}$ \\
\hline Phytoplankton & $\begin{array}{l}\text { The group of photosynthesising organisms in plankton, mainly unicellular algae and cyanobacteria and composed of } \\
57 \% \text { carbohydrates, } 26 \% \text { proteins and } 6 \% \text { lipids. }\end{array}$ \\
\hline Zooplankton & $\begin{array}{l}\text { The group of tiny animals, such as corals, krill and copepods, and microorganisms once classified as animals, such as } \\
\text { dinoflagellates and other protozoans. It is composed of } 44 \% \text { proteins, } 44 \% \text { lipids, } 5 \% \text { chitin and } 2 \% \text { carbohydrates. }\end{array}$ \\
\hline
\end{tabular}

2009). We therefore pay attention to this relationship as it is observed for Dutch sediments. Grain size analyses before about 1990 are based on sieve-and-pipette analysis whereas nowadays laser diffraction analysis is performed routinely. The two fundamentally different techniques yield different results, with different discrepancies systematically found for different sediment types (Konert \& Vandenberghe, 1997; Buurman et al., 2001). However, correlations for summed fractions are generally better than those for individual size fractions because of the integration among classes and limited shifts between classes. As a rule of thumb, the laser diffraction fraction of $<8 \mu \mathrm{m}$ is equivalent to the classic clay fraction $<2 \mu \mathrm{m}$ found by the pipette method (Konert \& Vandenberghe, 1997).

In the past, the 10 or $16 \mu \mathrm{m}$ grain size was frequently taken as the boundary between clay and silt or the $<16 \mu \mathrm{m}$ fraction was denoted with the Dutch word 'slib', which translates into English as silt or mud (Crommelin, 1943; Egberts, 1950; Favejee, 1951; Van Straaten, 1954; Pons, 1957; Verhoeven, 1962; De Groot, 1963). More recently, but still following the convention based on sieve-and-pipette analysis, the silt fraction has been defined as the 2-50 (Dutch soil classification; e.g. Van der Sluijs \& Locher, 1990) or 2-63 $\mu \mathrm{m}$ fraction (NEN 5104, 1989). Note that the latter fraction is most commonly used in geology. We will follow this definition and refer to the $<16 \mu \mathrm{m}$ fraction as the 'fine fraction' in addition to the clay fraction and the silt fraction. The term 'mud' has frequently been used within the context of marine or estuarine sediments. It denotes soft, clay-rich deposits with high contents of water. We will use this term in this context.

A general remark must be made when combining grain size analyses and chemical analyses. Carbonates and natural organic matter are mostly removed prior to grain size analysis. Thus grain size analyses refer to the silicate components of the sediment and some other minerals, and are not representative for the solid matrix as a whole. Moreover, different size classes are systematically underestimated because particulates that are associated with these size classes have been removed. This holds, for example, for the silt class in which Ca carbonates are commonly found (see later). A major proportion of the particulates may be removed, particularly in the case of suspended matter. Several studies point out that organic matter, carbonates and Fe colloids may account for up to $60 \%$ of the suspended matter (De Groot, 1963; Wartel, 1977; Van Eck, 1982a; Van de Meent et al., 1985): the highest fraction of $60 \%$ was found for autochthonously produced biomass in the northern part of Lake IJsselmeer at the end of 1970s when the lake was highly eutrophic. This was probably an extreme, but $10-30 \%$ will not be uncommon.

\subsection{Clay minerals analysis}

Clay minerals are often said to be the garbage bags of sediments and do not have fixed compositions in nature. As early as 1939, Favejee (1939) quantified the amount of the clay 
minerals illite + muscovite, kaolinite, montmorillonite and quartz as abundant, less abundant, few and not present using $\mathrm{X}$-ray diffraction (XRD) analysis. This technique has evolved during recent decades into more quantitative approaches, and it is worth noting that we are not aware of any published clay mineralogy study in which the accuracy of analysis is quantitatively indicated. The clay mineralogy of Dutch sediments as reported by Favejee (1939), Breeuwsma (1985), Huisman (1998) and Tebbens et al. (1998) was determined at Wageningen University. The methods and equipment used evolved with time and here we first describe the method reported in the PhD theses of Huisman (1998) and Tebbens (1999), and give the abbreviations for the other Wageningen studies as far as they are described.

Standard powder XRD analyses were performed on freezedried or air-dried samples. Clay mineralogy was determined by first treating the samples with $\mathrm{Na}$ acetate, $\mathrm{H}_{2} \mathrm{O}_{2}$ and $\mathrm{Na}$ dithonite to remove carbonates, organic matter and Fe and $\mathrm{Mn}$ oxyhydroxides. Subsequently, the clay fraction was separated by pipetting after settling, and X-ray diffractograms were made of oriented samples. Tebbens saturated his samples not only with $1 \mathrm{M} \mathrm{KCl}$ but also with $1 \mathrm{M} \mathrm{MgCl}_{2}$ and glycerol (these latter saturations are not mentioned in Huisman). The $\mathrm{KCl}$-saturated samples were additionally heated at $150^{\circ} \mathrm{C}$. The swelling characteristics were determined via XRD measurements of the 001 reflections. The diffractograms were digitised by hand. Semiquantitative peak surfaces were obtained by multiplying the 0.7 (kaolinite), 1.0 (illite), 1.4 (chlorite and vermiculite) and 1.8 $\mathrm{nm}$ (smectite with glycol in its interlayer) peak heights above the background with the peak widths at half-peak heights. According to Tebbens (1999), reliable relative clay percentages can then be calculated within one dataset by dividing the peak surface for an individual clay mineral by the sum of all peak surfaces. Both Huisman and Tebbens also used the major and trace element content of the clays in the interpretation of the clay minerals. The method of Breeuwsma is similar to the method of Tebbens but he did not saturate his samples with $\mathrm{KCl}$ and measured his air-dried samples also after heating them to 300 and $500^{\circ} \mathrm{C}$. The $300^{\circ} \mathrm{C}$ diffractograms were used to distinguish vermiculite and chlorite. Breeuwsma used not only the XRD results but also the $\mathrm{K}_{2} \mathrm{O}$ content (illite), $\mathrm{K}$-fixation (vermiculite), cation exchange capacity (CEC; smectite) and loss on ignition (chlorite) of the clays for the presence of a mineral. Irion \& Zöllmer (1999) made their XRD analyses of the North Sea sediments without the removal of carbonate, organic matter and iron. In order to obtain a standard condition for cation fixation and for a better recognition of the minerals, the $<2 \mu$ m fraction on the smear slides was treated with $\mathrm{Mg}$ acetate, $\mathrm{K}$ acetate and the vapour of ethyleneglycol at $80^{\circ} \mathrm{C}$. Only the four common main groups of clay minerals, smectite, illite, kaolinite and chlorite, could be distinguished. Semi-quantitative contents for each group were obtained on the basis of weighted peak areas.
The quantitative method used by Zeelmaekers (2011) and Adriaens (2014) is extensively described by the first and is at present the state-of-the-art methodology for how quantitative clay mineral analyses should be made. Preparation of the samples for the XRD, however, is similar, as is described above. The major difference is that the samples are saturated with $\mathrm{Ca}\left(1 \mathrm{M} \mathrm{CaCl}_{2}\right)$ after the selective leaching of the samples to remove the carbonate, organic matter and the Fe oxyhydroxides. Oriented samples are made by sedimentation slides because they produce overall higher quality diffraction patterns than smear mounts. Routinely, the XRD recordings are recorded in three different states: air dry, 'glycolated' and heated at $550^{\circ} \mathrm{C}$ for 1 hour. These recordings are used to identify the main clay groups (smectite, illite, kaolinite and vermiculite). Ambiguities can be resolved by analysing oriented slides in additional cationic forms such as $\mathrm{Mg}$ and $\mathrm{K}$ (vermiculite) and $\mathrm{Li}$ (montmorrillonite as smectite species). The main difference with the Wageningen method is the characterisation of mixedlayered phases by modelling of the oriented slide diffraction patterns. For this modelling the Sybilla program (Chevron proprietary software) is used. It is designed to calculate theoretical XRD patterns of the basal reflections of discrete and mixed-layered clay minerals, and to combine them to model the compositions of experimental diffraction patterns. The use of independent control parameters such as CEC and chemistry serves as an additional support for the accuracy of the method.

\subsection{Reactive Fe minerals}

Reactive Fe minerals are important constituents of sediments and they have been studied in Dutch sediments in six different ways. First, concretions or small associations of pyrite, siderite (which after exposure to air changes colour from white to yellow), vivianite (changes from white to blue after air exposure) and Fe oxides together with coatings (particularly of Fe oxyhydroxides) have been observed with the naked eye in sediment samples. Second, a few optical and electron microscopy studies have been performed and it is worth noting that these have identified several Fe oxides appearing as opaque minerals in reflecting light under the microscope (goethite, magnetite, hematite, ilmenite and chromite). Third, selective extractions have been performed, in which extracted amounts have been interpreted as solid compounds such as acid volatile sulphides or amorphous Fe hydroxides. It must be remembered that other minerals also dissolve when natural soil or sediment samples are subjected to extraction techniques (e.g. Fe-bearing Al silicates; Griffioen \& Broers, 1993), therefore assuming that the operationally extracted amounts equal the true mineralogical contents can be a slight to gross simplification, depending on the mineralogical composition of the sediment analysed. Fourth, total elemental analysis is used to calculate solid compounds, making basic assumptions about the presence of individual 
minerals and neglecting other minerals. This is used in particular to determine pyrite content in aquifer sediments, where pyrite is calculated from total sulphur and the associated Fe is a fraction of total Fe. Fifth, XRD is used to identify Fe minerals if these are present in substantial amounts. This technique is especially powerful for siderite, which is difficult to identify by means of other routine techniques. Finally, Hartog et al. (2002), Hyacinthe \& Van Cappellen (2004) and Zhang et al. (2012) used unique, specialised techniques, which will be mentioned in the following sections.

Geochemical analyses have increasingly been used to deduce which reactive Fe minerals are present and in which amounts. Reactive Fe is defined as the fraction of Fe that is not present in $\mathrm{Al}$ silicates. This means that the reactive Fe minerals are considered to be Fe sulphides, Fe oxyhydroxides, siderite, Fe phosphates and also the clay mineral or mica glauconite. Glauconite is an Fe-rich mica of marine diagenetic origin, with the general formula $(\mathrm{K}, \mathrm{Na}, \mathrm{Ca})_{1.2-2}(\mathrm{Fe}, \mathrm{Al}, \mathrm{Mg})_{4}\left(\mathrm{Si}_{7-7.6} \mathrm{Al}_{1-0.4} \mathrm{O}_{20}\right)$. Jarosite in acid sulphate soils might also be a reactive Fe mineral, since it is formed by pyrite oxidation. Huisman \& Kiden (1998) and Dellwig et al. $(2001,2002)$ proposed calculating reactive Fe as the difference between total Fe and Fe bound to unreactive minerals such as Al silicates, ilmenite or possibly chromite. Unreactive Fe is empirically estimated as one quarter of total Al. Subsequently, total reactive Fe is calculated as the difference between total Fe and unreactive Fe:

$$
\mathrm{Fe}_{\mathrm{TR}}=2 \times \mathrm{M}_{\mathrm{Fe}} / \mathrm{M}_{\mathrm{Fe} 203} \times\left[\mathrm{Fe}_{2} \mathrm{O}_{3}-0.25 \mathrm{Al}_{2} \mathrm{O}_{3}\right]
$$

where $\mathrm{Fe}_{\mathrm{TR}}$ is total reactive $\mathrm{Fe}, \mathrm{M}_{\mathrm{i}}$ refers to molar mass of compound $\mathrm{i}$, and $\mathrm{Fe}_{2} \mathrm{O}_{3}$ and $\mathrm{Al}_{2} \mathrm{O}_{3}$ are total $\mathrm{Fe}$ and $\mathrm{Al}$ contents, respectively, expressed on an oxide basis.

It is worth pointing out that the empirical approach is in conflict with the findings of Canfield et al. (1992), who deduced half-lives of sedimentary iron minerals with respect to sulphidation. They concluded that the half-life for sheet silicates is 84,000 years, which is within the time frame of the Pleistocene period. Weathering of Fe-Al silicates may lead to reactive Fe minerals, dissolved ferrous Fe and secondary kaolinite, or a secondary clay mineral that contains Fe mobilised by this weathering. This means that the empirical relationship may be useful for Holocene sediments, but might be more questionable for sediments of Middle Pleistocene age and older. Here, the conclusion of Canfield et al. (1992) is probably a simplification too. It is also worth mentioning that in the 19th century Van Bemmelen (1863) proposed the concept of a fixed $\mathrm{Al}_{2} \mathrm{O}_{3}$ to $\mathrm{Fe}_{2} \mathrm{O}_{3}$ ratio in silicates of clay: the $\mathrm{Fe}_{2} \mathrm{O}_{3}$ content is about $7 \%$ when the $\mathrm{Al}_{2} \mathrm{O}_{3}$ content is $15-20 \%$ and it is $2.5 \%$ at the transition between clay and sand.

In a subsequent step, pyrite-bound $\mathrm{Fe}$ can be isolated from the total amount of reactive Fe. Pyrite content and pyrite-bound Fe are often calculated from the total $S$ content for clastic sediments, where total $S$ content is assumed to represent pyrite (Van Gaans et al., 2011; Griffioen et al., 2012):

$$
\mathrm{FeS}_{2}=0.5 \times \mathrm{M}_{\mathrm{FeS}_{2}} / \mathrm{M}_{\mathrm{S}} \times \mathrm{S}
$$

and

$$
\mathrm{Fe}_{\mathrm{py}}=0.5 \times \mathrm{M}_{\mathrm{Fe}} / \mathrm{M}_{\mathrm{S}} \times \mathrm{S}
$$

where $\mathrm{FeS}_{2}$ is pyrite content, $\mathrm{Fe}_{\mathrm{py}}$ is pyrite-bound $\mathrm{Fe}$ and $\mathrm{S}$ is total sulphur. By subtracting pyrite-bound $\mathrm{Fe}$, the non-pyrite bound reactive $\mathrm{Fe}\left(\mathrm{Fe}_{\mathrm{reac}}\right)$ can be calculated:

$$
\mathrm{Fe}_{\text {reac }}=\mathrm{Fe}_{\mathrm{TR}}-\mathrm{Fe}_{\mathrm{py}}
$$

These formulae work well as long as total reactive Fe is higher than total $S$, taking into account stoichiometry. The presence of organic S, gypsum or other Fe sulphides is neglected. For Dutch conditions, this holds for sediment below a few metres depth and other than peat, but not for samples from sediment in which early diagenesis or pedogenesis is ongoing, i.e. samples from recent sediments or soils. Note that international field studies on $S$ speciation have revealed that iron sulphides other than pyrite are usually negligible in different kinds of sedimentary groundwater settings (e.g. Bates et al., 1998; Massmann et al., 2004; Chambers \& Pederson, 2006; Jakobsen \& Cold, 2007; Schwientek et al., 2008). Interpretation of incubation experiments based on reaction stoichiometry also indicates that pyrite is present as a reductant in various Dutch aquifer sediments (Hartog et al., 2002, 2005; Van Helvoort et al., 2007). Further, the presence of $\mathrm{S}$ as barite is negligible, where $\mathrm{Ba}$ is dominantly present in $\mathrm{K}$ feldspar (Klein \& Griffioen, 2010). Oenema et al. (1990a,b) and Hartog et al. (2002) used $\mathrm{HNO}_{3}$ extraction combined with total $S$ analysis as a more direct method to determine the pyrite content, where the molar Fe to $S$ ratio was close to 0.5 . Regrettably, this method has not been applied more often. For recent, aquatic fresh sediments, the pyrite content has been calculated as the difference between total $S$ and acid volatile sulphide (AVS) content, where total $S$ has been analysed by either CS elemental analyser or aqua regia destruction and ICP analysis. AVS has often been assumed to equal mackinawite $(\mathrm{FeS})$, greigite $\left(\mathrm{Fe}_{3} \mathrm{~S}_{4}\right)$ and dissolved sulphides (when pore water was included in the analysis), which are also precursors for pyrite. These assumptions have been heavily criticised by Rickard and Morse (2005). The Dutch data for the individual aquatic sediment samples in fresh environment show that the AVS content is often considerably smaller than the total $S$ content, as summarised in the next section. This means that most of the total $S$ will indeed be pyrite, also because the contribution of organic $S$ is probably small for samples that typically contain several to $10 \%$ of organic carbon. For estuarine environments, Oenema (1990a,b) found that AVS can approximately equal $\mathrm{HNO}_{3}$ extractable pyrite-S. This means that AVS cannot be neglected relative to total $S$ for these sediments but leaves open the question of what AVS actually represents in this case. 


\subsection{Carbonate analysis}

The carbonate content of sediments is an important characteristic. Different analytical techniques have been used to characterise the carbonate content of Dutch sediments. The most common ones nowadays are CS elemental analysis and thermogravimetric analysis (TGA). In CS elemental analysis, carbonate is measured after removal of organic matter or calculated as the difference between total $\mathrm{C}$ and organic $\mathrm{C}$. The latter may have a substantial relative error when two large numbers are subtracted from each other. In both cases, it is mostly assumed that all carbonate is calcite or aragonite and not dolomite or siderite, which is not self-evident. The same implicit assumption is made in TGA analysis, where carbonate is commonly calculated from the weight loss between $550^{\circ} \mathrm{C}$ and $800^{\circ} \mathrm{C}$. Other processes may interfere in this trajectory, such as loss of $S$ from pyrite, or loss of crystal water from the clay minerals kaolinite and montmorillonite (Guggenheim \& Koster van Groos, 2001; Roskam et al., 2008). The representativeness of these analyses thus depends on the mineralogical composition of the sample. Marine sediments are generally most complicated because of the co-occurrence of organic matter, carbonates and Fe sulphides. Ca carbonate content has also been calculated from total $\mathrm{Ca}$, based on X-ray fluorescence (XRF) and assuming a baseline between total $\mathrm{Ca}$ and total $\mathrm{Al}$ that represents $\mathrm{Ca}$ feldspar and $\mathrm{Ca}, \mathrm{Al}$ silicates (Bakker et al., 2007):

$$
\mathrm{CaO}_{\text {carb }}=\mathrm{CaO}_{(\mathrm{XRF})}-\left(0.0488 \mathrm{Al}_{2} \mathrm{O}_{3(\mathrm{XRF})}-0.1147 \%\right)
$$

The role of exchangeable $\mathrm{Ca}$ also deserves attention. Note that for a clayey sediment having a CEC of $50 \mathrm{meq} / 100 \mathrm{~g}$ and a Ca occupancy of $80 \%$, the $\mathrm{Ca} 0$ content is $1.1 \%$. If the relationship was established for a fresh groundwater environment in which Ca was the dominant cation, exchangeable Ca will also be included in the baseline. The relationship may then be less useful for groundwater environments dominated by $\mathrm{Na}$ and $\mathrm{Mg}$. Otherwise, exchangeable Ca goes at the expense of Ca carbonate.

Verhoeven (1962) presents three extraction methods for studying the co-occurrence of dolomite with calcite and aragonite, which gave some agreement among them: (1) difference in selective extraction between mild acetic acid and strong chloric acid, where the first extraction is assumed to represent calcite and aragonite and the latter also includes dolomite, (2) analysing $\mathrm{Mg}$ soluble in $8 \% \mathrm{HCl}$ and correcting for exchangeable $\mathrm{Mg}$ and (3) kinetic analysis of the $\mathrm{CO}_{2}$ production during Scheibler analysis. The first method has been the most commonly used in the past.

\section{Fluvial and alluvial sediments}

Fluvial sediments have been deposited almost continuously since the Pliocene in the Netherlands. As shown in Fig. 4, a series of six formations is distinguished for the Rhine sedi- ments whereas two formations (the Peize and Appelscha Formations) are distinguished for the northeastern Eridanos and North German systems. The Meuse system is associated with a single formation: the Beegden Formation. Two less extensive regional river systems are the Scheldt system in the southwest of the Netherlands and the Ems system in the northeastern corner of the Netherlands. In addition to these large river systems, there are alluvial sediments that form part of the heterogeneous geological formations of Boxtel (local drainage systems) and Stramproy (a river system draining northeast from Belgium).

\subsection{Heavy minerals}

4.1.1 Heavy mineral provinces. Heavy minerals have been intensively studied in the Netherlands in order to elucidate the stratigraphy, provenance and paleogeography of Dutch sediments. They are therefore dealt with first in this section. Edelman (1933) was the first to study the mineralogical composition of the Dutch Quaternary deposits by examining sand-sized minerals both qualitatively and quantitatively. His classification of the heavy mineral associations resulted in so-called mineralogical provinces. Each province had its specific composition that resulted from the source(s) of supply. Care was therefore taken to establish the associations of major components and their specific appearance. Edelman also paid attention to numerical variations, distinguishing between 'freak percentages', changes in the geological hinterland and the interference of mineral provinces. He distinguished six sediment-petrological provinces (Table 3; Edelman, 1933), which were later expanded to eight provinces (Edelman, 1934; Van Baren, 1934). Two groups were considered to be the on-shore continuation of the marine Young Tertiary/Quaternary A group (see section 5.1.1), both having a northern Scandinavian origin:

- A group with hornblende, epidote and garnet predominating, present in 'marine and glacial' deposits.

- $\mathrm{X}$ group with epidote and rutile predominating, present in 'fluvio-glacial' deposits.

The other six groups belong to the so-called terrestrial B association, with a southerly to easterly provenance:

- B Scheemda group with the metamorphic heavy minerals kyanite, staurolite, andalusite and sillimanite predominating (from rivers from the Baltic area).

- B Saussurite group with saussurite and epidote, and in places augite predominating, from the older Pleistocene Rhine river system. In the literature, often referred to as the Rhine $S$ association.

- B Lobith group (Edelman 1934) similar to the B Saussurite group but with abundant augite, from 'recent' Rhine material (see also Van Andel, 1950), the augite originating from volcanic rocks in the Eifel area. In the literature, often referred to as the Rhine AS association. 
Table 3. Standard heavy mineral composition (in counts of 100) determined in the original six heavy mineral assemblages distinguished by Edelman (1933).

\begin{tabular}{|c|c|c|c|c|c|c|c|c|c|}
\hline HMA & Garnet & Hornblende & Epidote & Saussurite & Staurolite & Augite & Tourmaline & Metamorphic & Zircon \\
\hline A group & 31 & 24 & 27 & 1 & 2 & 1 & 2 & 3 & 8 \\
\hline $\mathrm{X}$ group & 4 & 3 & 54 & 1 & 1 & 0 & 3 & 6 & 15 \\
\hline B scheemda group & 1 & 0 & 0 & 0 & 16 & 0 & 25 & 34 & 8 \\
\hline B saussurite group & 3 & 7 & 20 & 40 & 1 & 20 & 2 & 0 & 4 \\
\hline B Limburg group & 0 & 0 & 0 & 0 & 15 & 0 & 30 & 16 & 20 \\
\hline B Elsloo group & 10 & 50 & 8 & 8 & 0 & 0 & 10 & 0 & 17 \\
\hline
\end{tabular}

- B Limburg group, in which the metamorphic minerals are characteristic and stable minerals (e.g. tourmaline, zircon) with a southerly provenance are abundant.

- B Elsloo group with brown-green amphibole predominating, with a southerly provenance.

- B Eijsden group (van Baren, 1934) with abundant stable minerals and the Meuse chloritoid, representing the presentday Meuse sands.

4.1.2 Heavy mineral associations in fluvial formations. The method developed by Edelman was adopted by later researchers, but his sedimentary petrological provinces, defined as a group of sediments which constitute a natural unit in terms of age, origin and distribution, were later only used to derive paleogeographic conclusions or the origin of given sediments, as they do not enable sediments to be dated unequivocally unless the principle of superposition can be used (Zonneveld, 1958). A concept entirely different from that of the province is the mineral association: the particular combination of minerals that characterise a sediment. Essentially, the combination of minerals that characterises a sediment comprises two associations: a stable association (of minerals such as zircon, rutile, anatase and tourmaline) with/or without the metamorphic group index minerals (staurolite, kyanite, chloritoid, sillimanite and andulusite) and an unstable association (as well as epidote and garnet, also (and often dominantly) alterite and saussurite). In Table 4 the Dutch fluvial Pleistocene and Holocene formations (De Mulder et al., 2003; Ebbing et al., 2003) are classified in stable and unstable associations according to the above division. The three youngest formations of the Rhine system are in addition to the unstable heavy mineral association characterised by a relatively high content of volcanic minerals, mainly augite, resulting from renewed volcanism in the Eifel region. Guide minerals for the Meuse are the presence of Vosges hornblende and the specific Meuse chloritoid and garnet and for the Baltic sediments the presence of sillimanite.

Table 3 illustrates that mineralogical analysis can reveal the provenance of a fluvial sediment, particularly when combined with superposition. However, when rivers coalesce or when a river has reworked the deposits of another river, the resulting heavy mineral composition depends on the volumes of sediment from each river and their respective heavy mineral frac- tion. From the point of confluence of the Rhine and Meuse onwards and also when the Meuse system reworked Rhine deposits during the Pleistocene or Holocene, the Meuse signature in heavy mineral composition fades rapidly, obscured by locally incorporated Rhine sediment. Some samples, for example, contain plenty of Eifel volcanic minerals that indicate Rhine provenance, but also show relatively high percentages of staurolite, metamorphic minerals and tourmaline, and have an overall low heavy mineral concentration that is atypical for Rhine sediments. When, in such cases, Rhine provenance is further contradicted by indications from other proxies such as detrital carbonate content (low: Meuse; high: Rhine) and flint within the gravel fraction (high: Meuse; low: Rhine-Meuse; absent: Rhine), the deposits studied are interpreted as having most recently been reworked by a Meuse system (Zonneveld, 1947, 1958; Busschers et al., 2007). For example, when the rivers Rhine and Meuse coalesced during the Pleistocene or Holocene, the influence of the Rhine sediments (the larger river) predominates over the influence of the Meuse. This effect is even more important in the resulting heavy mineral association (HMA) because Rhine sediments contain a much larger fraction of heavy minerals than the Meuse sediments (Zonneveld, 1958). In Rhine deposits reworked by the Meuse, it is important to detect the Meuse signature in order to be able to infer that such deposits were last reworked by the Meuse river system (Zonneveld, 1947; Busschers et al., 2007).

Another example of how HMAs can be used to unravel the complex Late Pliocene and Early Pleistocene fluvial history of the Netherlands and the southern North Sea Basin is illustrated by Westerhof (2009). In the southern part of the Netherlands, fluvial deposition took place (the Rhine, Meuse and the northward-draining Belgian rivers), whereas in the central and northern part of the Netherlands, the Eridanos fluvialdeltaic system was important. During the Early Pleistocene, the Rhine-Meuse river system deposited a small lobate delta within the vast fluvio-deltaic Eridanos system. The deposits of both systems interdigitate in the central and western parts of the Netherlands. From the point that the Rhine-Meuse system became confluent with the Eridanos system, the specific petrographically controlled fingerprint of the Rhine deposits is lost, but remains inferable from the presence of Meuse flint in the gravel fraction. Contemporaneous deposits from Belgian rivers 
Table 4. Heavy mineral and feldspar assemblages determined in the Dutch Quaternary fluvial deposits. Data for the heavy minerals are taken from Zonneveld (1958), Doppert et al. (1975) and Westerhoff (2009). Feldspar data are from Van Baren (1934).

\begin{tabular}{|c|c|c|}
\hline Formation & Heavy mineral assemblages & Feldspars \\
\hline \multicolumn{3}{|l|}{ Eastern river system } \\
\hline Appelscha & $\begin{array}{l}\text { Unstable HMA: garnet, epidote and hornblende with staurolite, metamorphic minerals } \\
\text { and tourmaline }\end{array}$ & Microcline \\
\hline Peize & $\begin{array}{l}\text { Stable HMA: garnet, epidote and locally abundant hornblende with abundant } \\
\text { coarse-grained staurolite, metamorphic minerals and tourmaline }\end{array}$ & Microcline \\
\hline \multicolumn{3}{|l|}{ Rhine } \\
\hline $\begin{array}{l}\text { Echteld (Rhine and mixed } \\
\text { Rhine-Meuse deposits) }\end{array}$ & Unstable HMA: no detailed information & Albite/orthoclase \\
\hline $\begin{array}{l}\text { Kreftenheye (Rhine and } \\
\text { mixed Rhine-Meuse } \\
\text { deposits) }\end{array}$ & $\begin{array}{l}\text { Unstable HMA: augite-rich, garnet, epidote, saussurite/alterite and hornblende } \\
\text { Rhine sands of the AS association }\end{array}$ & Albite/orthoclase \\
\hline Urk & $\begin{array}{l}\text { Unstable HMA: garnet, epidote, saussurite/alterite and green hornblende with abundant } \\
\text { augite } \\
\text { Rhine sands of the AS association }\end{array}$ & Albite/orthoclase \\
\hline $\begin{array}{l}\text { Sterksel (mixed Rhine-Meuse } \\
\text { deposits) }\end{array}$ & $\begin{array}{l}\text { Predominantly unstable HMA: garnet, epidote, saussurite/alterite and hornblende with } \\
\text { varying amounts of the stable minerals belonging to the Meuse HMA } \\
\text { Rhine sands of the S association }\end{array}$ & Albite/orthoclase \\
\hline $\begin{array}{l}\text { Waalre (mixed Rhine-Meuse } \\
\text { deposits) }\end{array}$ & $\begin{array}{l}\text { Predominantly unstable HMA: garnet, epidote, saussurite/alterite and hornblende with } \\
\text { varying amounts of the stable minerals belonging to the Meuse HMA } \\
\text { Rhine sands of the S association }\end{array}$ & Albite/orthoclase \\
\hline \multicolumn{3}{|l|}{ Pre-Rhine (Pliocene) } \\
\hline Kieseloolite & $\begin{array}{l}\text { Stable ( }>90 \% \text { ) HMA: zircon (increasing in fine fractions), staurolite, metamorphic } \\
\text { minerals and tourmaline }\end{array}$ & No information \\
\hline \multicolumn{3}{|l|}{ Meuse } \\
\hline Beegden & $\begin{array}{l}\text { Stable HMA: tourmaline, metamorphic minerals, rutile, zircon, anatase together with } \\
\text { garnet, epidote and hornblende } \\
\text { In the upper part of the Formation unstable minerals are more abundant, with the Vosges } \\
\text { hornblende and Meuse chloritoid as guide minerals }\end{array}$ & Orthoclase \\
\hline \multicolumn{3}{|l|}{ Belgian rivers } \\
\hline Kreekrak and Koewacht & No information & No information \\
\hline Stramproy & Stable HMA: zircon, staurolite, metamorphic minerals and tourmaline & No information \\
\hline
\end{tabular}

HMA, heavy mineral assemblage.

draining north and northeastwards (Stramproy Formation) in the southern part of the Netherlands, more specifically in the Roer Valley Graben, are also easily recognisable, but lose their specific petrographical characteristics as soon as they become confluent with the Rhine-Meuse fluvial system. However, the presence of easily recognisable Belgian river deposits at certain depths in the Roer Valley Graben proves that the Rhine did not continuously deposit sediments in the Roer Valley Graben.

Electron microprobe analysis of detrital garnets from Quarternary Rhine, Meuse and Baltic River sediments were studied by Tebbens et al. (1995) to trace back the provenance and relative contributions from different source lithologies in each drainage basin. High-grade metamorphic almandine- and pyrope-rich garnets from the Vosges and Black Forest dominate the Rhine garnet suite in the Late Pliocene. With the onset of the Pleistocene, the Alpine Foreland Molasse is connected to the Rhine drainage area, supplying grossular- and probably also spessartine-rich garnets. The connection of the Aare and other Alpine tributaries to the Rhine in the Middle Pleistocene finally introduced large amounts of almandine-rich garnets derived from high-grade regionally metamorphosed inner Alpine source lithologies. The garnet suite of the Meuse sediments almost entirely consists of spessartines and Mn-rich almandines. They are derived from Mn-rich low-grade metamorphic pelites of the Libramont anticlinal region and the Stavelot Massif in the Ardennes. A small association of Mn-poor almandines is ascribed to a Vosges supply from before the capture of the Upper Meuse by the Moselle. The Baltic River garnet assemblages are characterised by a wide compositional spectrum, indicative of a large differentiated source area. The almandine- and 
pyrope-rich garnets are most likely derived from the extensive Fennoscandian Shield, while the spessartine-rich specimens are thought to originate from the mid-German Variscan massifs.

It is worth drawing attention to Krippner \& Bahlburg (2013), who analysed detrital zircon on $\mathrm{U}-\mathrm{Pb}$ ages and associated heavy mineral assemblages from Pleistocene Rhine River Middle Terrace sands and equivalents between the Swiss-German border and Cologne. They tested the assumed Alpine provenance of the sediments. According to these authors, the zircon age populations of all samples show similar distributions, their main age peaks being between 300 and 500 million years. Minor age populations are recognised at 570 and 1070 million years. Krippner \& Bahlburg (2013) note the absence of ages younger than 200 million years and in particular any ages reflecting the Alpine orogeny between c. 100 and 35 million years in their age distribution of detrital zircon from Rhine River sediments. Therefore, these authors question the commonly made assumption of a direct delivery of detritus to the downstream Rhine River system from the Alps during at least some parts of the Pleistocene. Similarly, it would be necessary to reevaluate explanations on the provenance of Dutch sediments.

4.1.3 Modifications of the heavy mineral associations. The four principal factors that may modify the heavy mineral association from source to deposition are (1) weathering both in the source area and in the depositional basin, (2) mechanical abrasion during transport, (3) selective sorting of minerals according to size and density, and (4) chemical weathering after deposition. Size and density sorting in rivers generally leads only to small differences in the HMAs (Zonneveld, 1946; Van Andel, 1950, 1958; Kasse, 1988). Only where an erosion pavement has been formed by the winnowing out of the less dense grains do the heavier grains become concentrated, as happens during erosion of river bars and slopes. A low rate of sediment supply coupled with conditions of intense weathering can strongly modify the composition of the heavy mineral associations (Van Loon \& Mange, 2007; Van Loon, 2009; section 5.1.6). During high rates of sediment supply (i.e. sediments generally derived directly from source areas where active erosion is occurring) the influence of all four factors is negligible and the heavy mineral assemblage directly reflects the petrography of the source area.

The impact of weathering is shown by a decrease in the less stable components pyroxene, amphibole and epidote, and a corresponding increase in the stable elements kyanite, staurolite, tourmaline, zircon and rutile (Table 5). In extreme cases this process can supposedly convert an amphibole-epidote association into a kyanite-staurolite-zircon assemblage (Weyl, 1949). Weathering of the heavy minerals in Dutch sediments has been described for podsol soil profiles (Van den Marel, 1949; Weyl, 1952a; Van Andel 1952; Eisma, 1968) and silica sand deposits (Van Loon \& Mange, 2007; Van Loon, 2009). In both cases the in situ weathering is caused by leaching of humic and/or other acids after deposition of the sediments. No quantitative data
Table 5. Stability of some common heavy minerals under chemical weathering (Friis, 1974).

\begin{tabular}{llll}
\hline $\begin{array}{l}\text { Extremely } \\
\text { unstable }\end{array}$ & Unstable & Stable & $\begin{array}{l}\text { Extremely } \\
\text { stable }\end{array}$ \\
\hline Olivine & Epidote & Staurolite & Tourmaline \\
Pyroxene & Garnet & Andalusite & Rutile \\
Apatite & & Silimanite & Zircon \\
Amphibole & & Kyanite & \\
\hline
\end{tabular}

are given, but the podsol profiles have higher garnet fractions in the heavy minerals of their B horizons, indicating that minerals such as amphibole, epidote and saussurite are more easily dissolved. In general, soil formation in the Dutch fluvial sequences is weak and thus the effect of leaching is very small. The pedochemical weathering of the silica sands is described in section 5.1.6. Weathering of heavy minerals (as well as micas and feldspars) also impacts the groundwater composition by releasing cations such as Fe and $\mathrm{Mg}$. This may be relevant for Dutch groundwater environments where Ca carbonate has been leached (Griffioen et al., 2013).

\subsection{Clay minerals}

4.2.1 Recent Rhine and Meuse clays. The clay mineralogy of Dutch fluvial clays has been studied by Breeuwsma (1985; Table 6), Adriaens (2014; Table 7) and also Favejee (1951; Table 21). The latter performed the analyses only on air-dried samples, whereas Breeuwsma in addition also analysed probes of the samples treated with glycerol and probes treated with $\mathrm{K}$ and then heated to $300^{\circ} \mathrm{C}$. Table 21 shows that using the method of Favejee, illite is the dominating clay mineral, with only minor amounts of kaolinite and smectite (montmorillonite). In contrast, the analyses of Breeuwsma (Table 6) show that the dominant clay minerals in the Rhine and Meuse are illite, smectite and vermiculite, with minor amounts of kaolinite and chlorite. Breeuwsma attributed these differences to the sample preparation, analytical technique and standard minerals Favejee used and confirmed the presence of vermiculite independently by the K-fixation capacity of the vermiculite bearing clays. Adriaens (2014) confirmed that illite and smectite are the major minerals in the Rhine and Meuse clays with minor amounts of kaolinite and chlorite, but he did not report vermiculite in the Rhine-Meuse clays studied. Using the same analytical method as Adriaens, Zeelmaekers (2011) reported qualitiatively the possible presence of vermiculite in Rhine-Meuse sediments. The four data sets (derived from Adriaens, Zeelmaekers, Breeuwsma and Favejee) are not comparable and therefore conclusions on provenance or on the differences within fluvial clays or between fluvial and marine clays can be drawn from only one specific dataset. In this review we assume that the clay minerals are inherited from pre-existing parent rock or weathered material 
Table 6. Mineralogical composition (in wt\%) of the $<2 \mu \mathrm{m}$ fraction of some fluvial clays and marine clays in the Netherlands and muds from the North Sea surface (derived from Breeuwsma (1985), unless stated otherwise). Analyses were performed on samples after removal of organic matter, carbonates and sulphides.

\begin{tabular}{|c|c|c|c|c|c|c|c|c|c|c|}
\hline \multirow[b]{2}{*}{ Deposit } & \multirow[b]{2}{*}{ Kaolinite $^{\mathrm{b}}$} & \multirow[b]{2}{*}{ Illite ${ }^{c}$} & \multicolumn{3}{|l|}{ Clay minerals } & \multicolumn{3}{|c|}{ 'Free' oxides ${ }^{\mathrm{a}}$} & \multirow[b]{2}{*}{ Quartz } & \multirow[b]{2}{*}{ Feldspars } \\
\hline & & & Vermiculite $^{c}$ & Smectite $^{c}$ & Chlorite $^{c}$ & $\mathrm{SiO}_{2}$ & $\mathrm{Al}_{2} \mathrm{O}_{3}$ & $\mathrm{Fe}_{2} \mathrm{O}_{3}$ & & \\
\hline \multicolumn{11}{|l|}{ Fluvial clays } \\
\hline Rhine flood basin & $5-10$ & $35-40$ & $10-20$ & $10-15$ & $5-10$ & 3.43 & 1.44 & 4.30 & $5-10$ & $<5$ \\
\hline Rhine subatlanticum & $5-10$ & $30-40$ & $10-20$ & $15-20$ & $<5$ & 4.69 & 2.24 & 3.32 & $5-10$ & $<5$ \\
\hline Rhine subboreal & $5-10$ & $30-35$ & $5-10$ & $30-35$ & $<5$ & 4.76 & 1.84 & 3.48 & $5-10$ & $<5$ \\
\hline Meuse & $5-10$ & $30-35$ & $5-10$ & $30-35$ & $<5$ & 3.88 & 1.66 & 3.89 & $5-10$ & $<5$ \\
\hline Brook floodplain, east Netherlands & $5-10$ & $<10$ & $<5$ & $50-80$ & $0-20^{4}$ & $5-20$ & 2.45 & 3.40 & $5-10$ & $<5$ \\
\hline Freshwater tidal areas & $5-10$ & $35-40$ & $10-20$ & $10-15$ & $5-10$ & 2.57 & 1.33 & 3.25 & $5-10$ & $<5$ \\
\hline \multicolumn{11}{|l|}{ Marine clays } \\
\hline Seawater tidal areas & & & & & & 4.61 & 1.07 & 3.06 & $5-10$ & $<5$ \\
\hline Friesland/Groningen & $5-10$ & $30-40$ & $<5$ & $30-40$ & $<5$ & 7.12 & 1.16 & 2.52 & $5-10$ & $<5$ \\
\hline West Friesland & & & & & & 7.39 & 0.62 & 2.16 & $5-10$ & $<5$ \\
\hline Zeeland & & & & & & 5.52 & 1.03 & 2.81 & $5-10$ & $<5$ \\
\hline Paulina Marsh Zeeland ${ }^{\mathrm{d}}$ & $13-14$ & $42-49$ & & $33-39$ & 5 & & & & & \\
\hline North Sea surface ${ }^{\mathrm{e}}$ (average) & 10 & 51 & & 27 & 12 & & & & & \\
\hline (standard deviation) & 2.8 & 5.9 & & 8.6 & 2.6 & & & & & \\
\hline (max.min.) & $2-23$ & $34-67$ & & $5-53$ & $3-19$ & & & & & \\
\hline
\end{tabular}

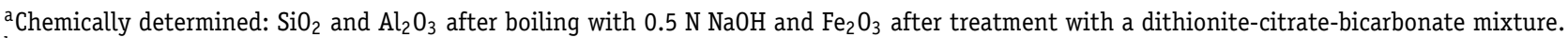

${ }^{\mathrm{b}}$ Chemically determined: after boiling with $0.5 \mathrm{~N} \mathrm{NaOH}$.

${ }^{\mathrm{c}}$ The estimation is related to the total number of layers in clay minerals. Smectite and vermiculite occur only as components in mixed layer clays with illite.

d After Zeelmaekers (2011).

eAfter Irion and Zöllmer (1999), no details on whether humus, carbonates and sulphides were removed.

and have not been transformed or newly formed in the soils and sediments after deposition (Breeuwsma, 1985; Tebbens et al., 1998). In the specific weathering studies reported, this is of course not the case.

The results reported by Breeuwsma (1985; Table 6) show that the main differences between the fluvial and marine clays are the vermiculite and smectite contents. Breeuwsma (1985) suggested that the absence of vermiculite in the marine clays is probably attributable to the presence of salt. Recent work by Skiba (2013) shows that vermiculite selectively adsorbs $\mathrm{K}^{+}$from seawater. Illitisation of dioctahedral vermiculite is very likely to occur in the early diagenesis of open systems in marine environments where sediments have unlimited contact with seawater. The chemical analysis of the $<2 \mu \mathrm{m}$ fraction shows further that there are also differences in the chemical composition: marine clays have higher iron contents. The $\mathrm{K}$ fixation and the CEC are greater in the fluvial clays than in the marine clays because the fluvial clays contain vermiculite and a smectite with a larger layer charge (Breeuwsma, 1985). The vermiculite and smectite contents in clays from the Rhine differ, depending on whether the clay was deposited before or after Roman times (Table 6). Variation in smectite content in the Rhine clays is also documented by Adriaens (2014; Table 7); the total illite: total smec- tite ratio varies between below one (Rhine-Meuse-Scheldt Early Pleistocene), equal to one (Rhine-Meuse Mid-Holocene) and larger than one (Rhine Early Holocene; Scheldt Early and MidHolocene). Huisman and Kidden (1998) reported that for the lower units of the Waalre Formation (Early Pleistocene Rhine) the clay is dominated by well-crystallised smectite with illite and kaolinite whereas for the upper units it is dominated by illite and kaolinite. Such large variations in clay mineralogy may be attributable to drastic climate or provenance changes in time (Tebbens et al., 1998; Alizai et al., 2012; Limmer et al., 2012).

The alluvial brook clays from the eastern part of the Netherlands have extremely high smectite contents which are clearly higher than the smectite contents in the Rhine and Meuse. The smectites must originate from deposits present in the catchments of these brooks: possible candidates are Paleogene and/or Neogene marine deposits or Cretaceous carbonates (Breeuwsma, 1985). Clays with such high smectite contents have very specific properties: high swelling capacities, CEC and $\mathrm{K}$ fixation.

4.2.2 Causes of changes in clay mineralogy. The Late Weichselian to Early Holocene transitional period (13-8 ka) was 
Table 7. Clay mineralogy (in wt\%) of Rhine-Meuse-Scheldt Holocene and Pleistocene fluvial clays (derived from Adriaens (2014)).

\begin{tabular}{|c|c|c|c|c|c|}
\hline River system & Kaolinite & Chlorite & Illite & Smectite & $\begin{array}{l}\text { Illite-smectite } \\
\text { (\%I:IS) }\end{array}$ \\
\hline Rhine-Meuse & 11 & 2 & 21 & 33 & $33(63: 37)$ \\
\hline Mid-Holocene & 9 & 2 & 16 & 29 & $44(63: 37)$ \\
\hline Rhine & 9 & 3 & 31 & 23 & $34(72-28)$ \\
\hline Early Holocene & 10 & 2 & 28 & 30 & $30(72-28)$ \\
\hline Meuse & 12 & 3 & 35 & 24 & $26(70: 30)$ \\
\hline \multirow[t]{3}{*}{ Mid-Pleistocene } & 14 & 2 & 33 & 27 & $24(70: 30)$ \\
\hline & 14 & 2 & 35 & 13 & $36(72: 28)$ \\
\hline & 13 & $<1$ & 15 & 26 & $46(72: 28)$ \\
\hline Rhine-Meuse-Scheldt & 1 & $<1$ & 5 & 52 & $42(60: 40)$ \\
\hline \multirow[t]{3}{*}{ Early Pleistocene } & 1 & $<1$ & 5 & 46 & $48(60: 40)$ \\
\hline & 9 & 1 & 19 & 33 & $38(60: 40)$ \\
\hline & 17 & 1 & 35 & 20 & $27(60: 40)$ \\
\hline Scheldt & 5 & 1 & 5 & 58 & 31 (67:33) \\
\hline \multirow[t]{3}{*}{ Mid-Holocene } & 6 & $<1$ & 4 & 68 & $22(74: 26)$ \\
\hline & 7 & $<1$ & 3 & 64 & $26(74: 26)$ \\
\hline & 5 & $<1$ & 4 & 65 & $26(74: 26)$ \\
\hline Scheldt & 5 & 1 & 5 & 53 & $36(74: 26)$ \\
\hline \multirow[t]{3}{*}{ Early Holocene } & 8 & $<1$ & 8 & 59 & $25(74: 26)$ \\
\hline & 8 & $<1$ & 6 & 64 & $22(69: 31)$ \\
\hline & 15 & $<1$ & 11 & 52 & $22(69: 31)$ \\
\hline
\end{tabular}

characterised by a general warming trend, interrupted by the Younger Dryas cooling phase. The effects of this climatic change on the composition of fine-grained residual channel infillings of the river Meuse were studied by Tebbens et al. (1998). They demonstrated that although sediment provenance has not changed, residual channel infillings display a systematic bulk compositional change related to climate change. Late-glacial and Holocene climatic amelioration stabilised the landscape and facilitated prolonged and intense chemical weathering of phyllosilicates and clay minerals due to soil formation. Clay translocation and subsequent erosion of topsoils on Palaeozoic bedrock and Pleistocene and younger loess deposits increased the amount of smectite and vermiculite within river Meuse sediments. Smectite plus vermiculite contents rose from $30-40 \%$ in the Pleniglacial to $70-80 \%$ in the Holocene. The data presented by Tebbens and co-authors show that a steady-state supply is reached within 5000 years. Holocene sediments therefore contain higher amounts of clay that, compared to Late-glacial sediments, are richer in high-Al, low-K and low-Mg vermiculites and smectites. The above results illustrate that the composition of river Meuse sediments cannot be considered constant on a 1-10 ka timescale.

Huisman (1998) reports a clear change in the clay mineralogy of the Brachterwald section (close to Venlo) of the fluvial Neogene Reuver Member (which is part of the Kieseloolite Forma- tion). In the lower part of this section (0-5.75 m) the dominant clay mineral is kaolinite (kaolinite $53 \%$, illite $25 \%$ and smectite $22 \%$ ) whereas in the upper part the dominant clay mineral is smectite (kaolinite $34 \%$, illite $18 \%$ and smectite $48 \%$ ). This change is also documented in distinctly higher $\mathrm{Ti} / \mathrm{Al}$ ratios in the section below $5.75 \mathrm{~m}$ and higher $\mathrm{Mg} 0$ content above 5.75 m. Boenigk (1974) found a shift in heavy minerals from local to Alpine provenance in the Brachterwald section, which appeared to be reflected by the above-mentioned drops in Ti/Al ratios and kaolinite contents and associated increase in smectite contents. Following Boenigk, Huisman (1998) interpreted these changes as being caused by a shift from locally derived sediments (strongly weathered, with high kaolinite contents) to Alpine-derived sediments (less weathered and higher smectite contents).

\subsection{Feldspars, micas and silica}

Little attention has been paid to contents of other silicates such as quartz, feldspars and mica minerals in fluvial sediments. Quartz usually accounts for over $70 \%$ and is thus the dominant mineral in sands (Van Baren, 1934). It is not the only $\mathrm{SiO}_{2}$ polymorph that is found in fluvial sediments: biogenic silica may be present as well. The information available on the concentration of biogenic silica in Dutch fluvial 
sediments and suspended matter is summarised in section 5 . Van Baren (1934) classified the fluvial formations on their feldspar assemblage: the results are summarised in Table 4. The difference between sediments from the Eridanos and the Rhine river systems is noteworthy: the former are dominated by microcline and the latter by orthoclase and albite. Druif (1927) microscopically observed orthoclase, little or no microcline and even less plagioclase in a few samples from the Meuse and Gulp rivers. Muscovite was always abundantly present, whereas biotite was found in both Meuse samples and in one out of three samples from the Gulp river. Geologists have not systematically distinguished biotite from mica in mineralogical descriptions, which is unfortunate because the weathering rates differ considerably and biotite can be a source of $\mathrm{Mg}$ in pore water. Crommelin (1943) characterised the suspended matter of the Rhine for different grain size classes and compared it with Wadden Sea and North Sea sediments (Table 24). He found a relatively high content of micas in the riverine suspended matter.

The $\mathrm{Na}_{2} \mathrm{O}$ content of sediments has been used to characterise the Na-feldspar content, on the assumption that all $\mathrm{Na}$ is found in feldspars. This is probably true for sand or loam in $\mathrm{Ca}-\mathrm{HCO}_{3}$ freshwater environments but unlikely for clay in an environment with Na-rich water such as seawater or fresh water having a $\mathrm{Na}-\mathrm{HCO}_{3}$ composition. The latter is found when fresh water has displaced saline groundwater, as in the case of the fresh groundwater body around Hoorn. Under such conditions, the CEC will largely be occupied with $\mathrm{Na}$ and this will contribute to the $\mathrm{Na}_{2} \mathrm{O}$-XRF content. Sediments have indeed been found to have a maximum $\mathrm{Na}_{2} \mathrm{O}$ content at an $\mathrm{Al}_{2} \mathrm{O}_{3}$ content of about $6-10 \%$ (Huisman, 1998, 1999), thereby establishing the occurrence of Na-feldspar in the silt and fine sand size class. Huisman \& Kiden (1998) noted shifts in the $\mathrm{Na}_{2} \mathrm{O}$ content from less than $0.4 \%$ to $0.4-1.3 \%$ (i.e. less than $3.4 \% \mathrm{Na}$-feldspar to $3.4-11 \%$ ) for $\mathrm{Al}_{2} \mathrm{O}_{3}$ content larger than $5 \%$ for fluvial sediments from the Tegelen and Kedichem Formations (currently classified as Waalre and Stramproy in the related study area). These shifts coincided with shifts in the heavy mineral assemblages from stable to unstable and were stated to be controlled by changes in the provenance of the Rhine from regional to Alpine as well as shifts between the Scheldt and Rhine systems. Similarly, Schokker et al. (2005) studied the abundance of Na-feldspars in the Sterksel Formation from five sediment cores across the Roer Valley Graben and Huisman (1999) made a more national inventory of fluvial formations. The $\mathrm{Na}_{2} \mathrm{O}$ content of about $1 \%$ is highest when $\mathrm{Al}_{2} \mathrm{O}_{3}$ is about $6-8 \%$, coinciding with fine sand and not with loam, clay or coarse sand. Assuming all $\mathrm{Na}_{2} \mathrm{O}$ is present as Na-feldspar, the Na-feldspar then amounts to about 8.5\%. Huisman (1999) observed that the Late and Middle Pleistocene Kreftenheije, Urk and Sterksel Formations are richest in Na-feldspar, the Early Pleistocene Waalre and Stramproy intermediate, and the Neogene Kieseloolite and Early Pleistocene Scheemda (nowadays part of the Peize Formation) Formations poorest.

\subsection{Ca carbonates}

4.4.1 Carbonate contents. Fresh sediments of the River Waal (which is part of the Rhine system) deposited during normal flow conditions contain $12-20 \% \mathrm{CaCO}_{3}$ where a weak relationship with the fine fraction is observed (De Groot, 1963). For high flow conditions, the carbonate content is about $12 \%$ and does not vary appreciably with the fine fraction. The carbonate content of recent Meuse sediment is lower: about $4 \%$ and invariant of the fine fraction. The carbonate content of suspended matter in the fluvial reaches of the Scheldt system is $11 \%$, based on four sampling events (Zwolsman \& Van Eck, 1999). The $\mathrm{CaCO}_{3}$ content of young sediments from Lake IJsselmeer varies only slightly with grain size from 0 to $75 \mu \mathrm{m}$ : the content is about 10\% (Verhoeven, 1962).

Table 8 presents statistical data on the carbonate contents of fluvial formations. The carbonate contents were determined by either the enrichment in total Ca content above a $\mathrm{Ca} / \mathrm{Al}$ baseline (Bakker et al., 2007; Van Gaans et al., 2007) or thermogravimetric analysis (other references mentioned in Table 8). Note that the contents determined by the former method are probably overestimated for clay and loam because the method does not take exchangeable $\mathrm{Ca}$ into account. On average, the clay and loam samples have higher contents than the sand samples for all formations, for reasons explained below. The high carbonate contents in sand of the Kreftenheije and Echteld Formations are striking, in particular in the Holland geotop region (which coincides with the provinces of North and South Holland, where marine deposits are present at or near the surface): the high contents in the Kreftenheije may be explained by local erosion and redeposition of Eem sand in this area in addition to accumulation of sediments from upstream (Busschers et al., 2007). Additionally, the Early and Middle Pleistocene fluvial formations that reach the surface were more prone to decalcification under palaeohydrological conditions (Griffioen et al., 2013). Table 9 presents an overview of the calcareous nature of a series of geological formations (Klein \& Griffioen, 2010), in which they combine a compilation of data obtained solely from thermogravimetric carbonate analyses and the description of the carbonate state of geological formations by De Mulder et al. (2003). The latter is based on qualitative HCl effervescence tests during borehole descriptions. One must realise that this test is indicative only and no effervescence happens when siderite or dolomite is involved. The analytical dataset mainly contains samples below the soil zone from the southern and northern Netherlands and is thus not representative at national scale. All fluvial formations are carbonate-poor to calcareous, although there are differences in range.

Different sedimentary facies of the Holocene confining layer (including the fluvial Echteld Formation) show different ranges in carbonate content (Table 10): crevasse-levee $>$ flood basin clays $>$ channel $=$ loam bed $>$ organic $=$ aeolian inland dune (Van Helvoort et al., 2007). Here, the low carbonate content in 
Table 8. Regional characteristics (as percentiles) of the pyrite, reactive Fe, organic matter and Ca carbonate contents in several Dutch fluvial geological formations.

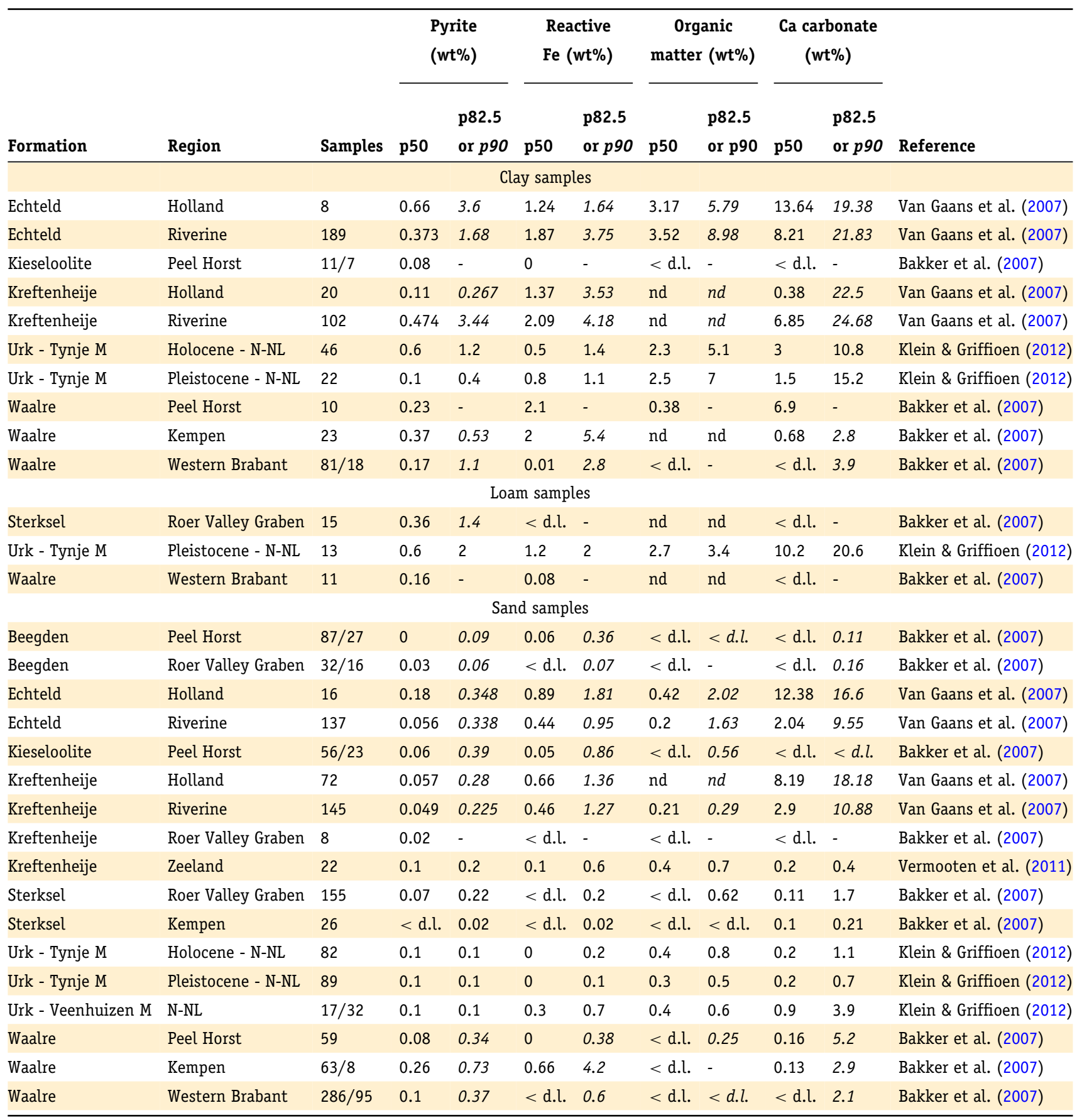

d.l., detection limit, which is commonly around $0.1 \%$.

The 82.5 percentile is given in regular and 90 percentile in italic.

M, Member; N-NL, northern Netherlands.

the aeolian inland dunes is the result of decalcification during the Early Holocene when the groundwater table was considerably lower than during Late Holocene and carbonate leaching could be more intense (see also Pons, 1957). Fragments of freshwater shells have typically been found in channel belt deposits. They also occur more sparsely in the heavy clayey flood basin deposits, where they are relics of the freshwater marsh fauna (Egberts, 1950).

The calcareous silty sediments of the Wijchen Member (sandy clay overbank deposits and residual channel deposits; part of Kreftenheije Formation) with high percentages of the 20-80 $\mu \mathrm{m}$ fraction were found to contain higher $\mathrm{CaO}$ and $\mathrm{MgO}$ contents 
Table 9. General characterisation of the $\mathrm{CaCO}_{3}$ state of Dutch Quaternary geological formations (derived from Klein \& Griffioen (2010)).

\begin{tabular}{lcccl}
\hline & & \multicolumn{2}{c}{ Fraction (\%) } & \\
\cline { 2 - 4 } Geological formation & Samples & $\mathbf{C a C O}_{3}<\mathbf{0 . 5}$ wt\% & $\mathbf{C a C O}_{3}>\mathbf{0 . 5}$ wt\% & General characterisation \\
\hline Naaldwijk & 421 & 2 & 98 & Generally calcareous, frequently with shell fragments \\
Nieuwkoop & 83 & 23 & 77 & Mostly calcareous \\
Echteld & 179 & 6 & 94 & Mostly carbonate-rich \\
Boxtel & 974 & 70 & 30 & Carbonate-free to carbonate-rich sand or loam \\
Kreftenheije & 113 & 31 & 69 & Mostly carbonate-rich \\
Beegden & 22 & 59 & 41 & Carbonate-free to carbonate-rich \\
Eem & 74 & 14 & 87 & Calcareous, frequently with shell fragments and locally shell-rich \\
Drente & 245 & 39 & 61 & Mostly calcareous \\
Drachten & 162 & 93 & 7 & Carbonate-poor \\
Urk-Tijnje Member & 307 & 49 & 51 & Carbonate-free to calcareous \\
Peelo & 325 & 68 & 32 & Carbonate-poor sand and carbonate-rich clay \\
Urk-Veenhuizen Member & 43 & 23 & 77 & Mostly calcareous \\
Sterksel & 33 & 76 & 24 & Partly calcareous \\
Stramproy & 72 & 83 & 17 & Mostly carbonate-free or carbonate-poor \\
Waalre & 201 & 21 & 79 & Mostly calcareous \\
\hline
\end{tabular}

Table 10. Median values of pyrite, organic matter and Ca carbonate contents (in wt\%) in different facies of the Holocene confining layer in the Bommelerwaard polder (derived from Van Helvoort et al. (2007)).

\begin{tabular}{|c|c|c|c|c|c|c|c|c|}
\hline \multirow[b]{2}{*}{$\begin{array}{l}\text { Sedimentary facies } \\
\text { and formation }\end{array}$} & \multirow[b]{2}{*}{$\begin{array}{l}\text { Samples } \\
\text { (oxic }+ \text { reduced) }\end{array}$} & \multirow[b]{2}{*}{$\begin{array}{l}\text { Dominant } \\
\text { lithology }\end{array}$} & \multicolumn{2}{|c|}{ Pyrite } & \multicolumn{2}{|c|}{ Organic matter } & \multicolumn{2}{|c|}{ Ca carbonate } \\
\hline & & & 0xic & Reduced & 0xic & Reduced & 0xic & Reduced \\
\hline Channel (Echteld) & $17+26$ & Very fine to coarse sand & 0.05 & 0.08 & 0.52 & 0.5 & 1.53 & 1.7 \\
\hline Crevasse/levee (Echteld) & $8+15$ & Sandy-silty clay & 0.04 & 0.27 & 3.08 & 4.6 & 10.7 & 11.3 \\
\hline Inland dune/decalcified (Boxtel) & $0+12$ & Very fine to fine sand & & 0.11 & & 0.34 & & 0.17 \\
\hline Inland dune (Boxtel) & $0+4$ & Very fine to fine sand & & 0.48 & & 4.91 & & 2.01 \\
\hline Flood basin (Echteld) & $9+21$ & Clay & 0.05 & 0.39 & 5.24 & 6.67 & 4.99 & 2.09 \\
\hline Peat (Nieuwkoop) & $0+20$ & Organic matter & & 2.34 & & 21.09 & & 2.39 \\
\hline
\end{tabular}

(Tebbens et al., 1998). Tebbens et al. attributed this to a loess admixture of these sediments, where the loess contains both calcite and dolomite.

$\mathrm{Ca}$ carbonate has been found to be related to the fine fraction $(<16 \mu \mathrm{m})$ in Rhine deposits of the Holocene riverine area in the central Netherlands (Egberts, 1950; Pons, 1957; Van Helvoort et al., 2005). The highest contents (up to $8 \% \mathrm{CaCO}_{3}$ ) were found in soils containing a fine fraction of $30-35 \%$, predominantly in silty crevasse-levee deposits. The associated topsoils may have low contents due to decalcification (see later). Soils that contain a fine fraction (i.e. $<16 \mu \mathrm{m}$ ) of about $60-65 \%$ do not contain $\mathrm{CaCO}_{3}$ above $0.5 \%$. Results further point out that calcite is negligible or absent in the clay fraction $(<2 \mu \mathrm{m})$ of fluvial clay deposits and also suspended matter (Van der Marel, 1950): less than $6 \%$ of total carbonate in the soil is present within the clay fraction.
A strong contrast exists in carbonate content between Rhine and Meuse sediments for Holocene fluvial deposits in the central-eastern Netherlands (Pons, 1957; Hakstege et al., 1993). The Holocene deposits of the river Meuse are calcareous upstream from Venlo because of an influx of calcareous loess (Stiboka, 1972). They are carbonate-free or poor $(<0.5 \%)$ downstream. This low carbonate content cannot always be attributed to decalcification during pedogenesis (Pons, 1957): the suspended load of the Meuse has a $\mathrm{CaCO}_{3}$ content similar to that of the Rhine. The low $\mathrm{CaCO}_{3}$ content of channel belt deposits of the Meuse system is therefore attributed to the inflow of acid water into the Dutch stretch of the river Meuse and the associated enhanced dissolution of suspended carbonate. This acid water originated from the bogs of the Peel before these bogs were dug away for fuel in historical times, as well as from acid tributaries of the Meuse River. An alternative explanation 
is provided by Van Helvoort (2003), who proposed that the variability of the carbonate contents in channel and floodplain deposits is probably caused by the uptake of decalcified cover sands by Meuse-dominated channels and, in the case of the floodplain deposits, by acidifying oxidation reactions in the topsoil due to large-scale drainage in recent times.

4.4.2 The occurrence of dolomite. There is various evidence of dolomite occurring in fluvial sediments in addition to calcite. Using XRD, Salomons (1975) characterised the mineralogy of recent freshwater sediments from the Biesbosch area sampled before closure by the Delta works and found that the dolomite fraction was about $15 \%$ of the total Ca carbonate content for lithological samples where $50 \%<20 \mu \mathrm{m}$, i.e. silt or clay samples. The ratio of acetic acid soluble carbonate to $\mathrm{HCl}$ soluble carbonate is close to 0.90 for the clay fraction of fluvial clay soils (Van der Marel, 1950) and varies by several per cent around $0.9 \%$ for the soil as a whole, which suggests about $10 \% \mathrm{Ca}$ carbonate as dolomite in both cases. Similar fractions are deduced from Smittenberg et al. (1998) for carbonate in the Tegelen Formation (now the Waalre Formation) in central Limburg, on the basis of XRF data. The allochthonous origin was further confirmed by observing detrital grains under a scanning electron microscope. For grain size classes $>10 \mu \mathrm{m}$, Crommelin (1943) observed microscopically that after removal of calcite, per 100 grains of suspended material of the river Rhine there were zero to 4 grains of dolomite and zero or 1 grain of dolomite per 100 grains of suspended material of the Ems.

4.4.3 Carbonate isotopes. Fluviatile detrital Ca carbonates may originate from eroded ancient marine carbonates and soils. Salomons (1975) characterised the $\delta^{13} \mathrm{C}$ and ${ }^{14} \mathrm{C}$ age of Ca carbonates in recent sediments of the rivers Rhine, Meuse (sampled at the Biesbosch before closure) and Ems (at Diele; Table 11). Summarising, he found that the river sediments are influenced by the supply of pedogenic carbonate for two reasons. First, the ${ }^{14} \mathrm{C}$ age of Rhine and Meuse carbonates was around 15 percent modern carbon (henceforth referred to as PMC) instead of $0 \%$ and that for the Ems was as much as 34 PMC. Second, the $\delta^{13} \mathrm{C}$ value is lighter than that for marine carbonates: below $-3 \%$ instead of around $0 \%$. Calcite may also be formed authigenically under early diagenetic conditions within gyttja deposits, which are found in infillings of oxbow lakes (Smittenberg et al., 1998). Smittenberg et al. also described the occurrence of calcite as a cementing agent in deposits of the Waalre Formation, without providing an explanation. The $\delta^{13} \mathrm{C}$ value of Lake IJsselmeer sediments is unique in the sense that it is the result of a Holocene marine material mixing with recently precipitated carbonate. The latter is or was the result of supersaturation associated with algal blooms and increased pH (Salomons \& Mook, 1980). The newly formed Ca carbonate has a $\delta^{13} \mathrm{C}$ value of $+2.2 \%$ and the observed average composition of the sediment was $+0.8 \%$, which differs by $3.4 \%$ from the value for the IJssel and Rhine rivers.
The isotopic composition of carbonate in Pleistocene fluvial sediments varies (Table 11). Hartog et al. (2005) found three groups for the Kreftenheije Formation samples in eastern Gelderland: (1) samples having isotopic signature for both $\delta^{18} 0$ and $\delta^{13} \mathrm{C}$, which is the same as that for present-day marine carbonates, i.e. carbonate probably of allochthonous origin, (2) samples depleted in $\delta^{18} 0$, reflecting syngenetic carbonate formation during glacial periods and (3) samples depleted in both $\delta^{18} 0$ and $\delta^{13} \mathrm{C}$ reflecting post-depositional carbonate precipitation under groundwater influence. Unfortunately, the elemental composition of the various carbonate samples is unclear. The latter group is probably Fe-bearing carbonate such as siderite or ankerite. Carbonated sandstone can be found at the flanks of ice-pushed hills in central Netherlands, where a series of isotope analyses show depleted values in both $\delta^{18} 0$ and $\delta^{13} \mathrm{C}$ (Table 11; Post, 2006). These values are enriched relative to regional groundwater and the exact mechanism that explains this feature has not been clarified.

4.4.4 Decalcification. Decalcification of fluvial sediments occurs in different settings. First, it happens under pedogenesis at the local scale. Van den Berg \& Loch (2000) attributed decalcification of fluvial wetland soils in the Biesbosch to a combined effect of increased $\mathrm{CO}_{2}$ partial pressures during wet periods and pyrite oxidation with associated carbonate buffering in periods of aeration under fluctuating hydrological conditions. Van den Berg \& Loch calculated a decalcification rate of about $3 \mathrm{mg}$ $\mathrm{CaCO}_{3} /$ (g soil.y) for the upper $20 \mathrm{~cm}$ of the soil, which must be considered as an upper limit, given the assumptions made. Pons (1957) characterised local decalcification during pedogenesis for different kinds of fluvial sediments. He distinguished different facies as well as age (before or after Roman times) and origin (Rhine or Meuse). The results are presented in Table 12. Jongmans and Miedema (1986) studied the existence of small remnants of calcareous sediments in Late Weichselian Rhine sediments devoid of carbonate as found in former river channels in the eastern Netherlands. They explained these remnants as originating from slabs of frozen, calcareous loamy sediments, transported in floes and redeposited in sandy channel belts under periglacial conditions. These slabs have been less decalcified than the surrounding sandy sediments due to their poorer permeability in combination with preservation below the groundwater table and/or higher initial carbonate content.

Second, regional decalcification of aquifers is a process at the geological time scale. For example, the decalcification of $1 \mathrm{~m}$ of sediment containing $1 \% \mathrm{CaCO}_{3}$ requires 250 years when $80 \mathrm{mg}$ $\mathrm{Ca} / \mathrm{l}$ dissolves, porosity is 0.33 and recharge rate is $360 \mathrm{~mm} / \mathrm{y}$. Here, $80 \mathrm{mg} / \mathrm{L}$ can be considered as a typical Ca concentration in groundwater. Palaeohydrological decalcification at the regional scale was investigated by Hemel \& Stuurman (1999) for the Roer Valley Graben area, North Brabant. They compiled information on the carbonate state of geological deposits from borehole descriptions. They argue that, at the regional scale, 
Table 11. Results of isotope analysis on carbonates in several Dutch geological sediments and the Belgian Boom Clay.

\begin{tabular}{|c|c|c|c|c|}
\hline $\begin{array}{l}\text { Sediment type } \\
\text { and location }\end{array}$ & $\begin{array}{l}\mathrm{CaCO}_{3} \\
(\mathrm{wt} \%)\end{array}$ & $\begin{array}{l}\delta^{18} 0 \text { carbonate } \\
(\% \mathrm{PDB})\end{array}$ & $\begin{array}{l}\delta^{13} \mathrm{C} \text { carbonate } \\
(\% \mathrm{PDB})\end{array}$ & Reference \\
\hline \multicolumn{5}{|l|}{ Recent sediments } \\
\hline \multicolumn{2}{|l|}{ Fluvial Rhine, Meuse } & & -3.6 to -3.3 & Salomons \& Mook (1981) \\
\hline \multicolumn{2}{|l|}{ Fluvial Ems, Scheldt } & & -5.0 & Salomons \& Mook (1981) \\
\hline \multicolumn{2}{|c|}{ Hollands Diep/Haringvliet (Rhine) - prior to closing-off } & & -2.0 to -0.6 & Salomons \& Mook (1981) \\
\hline \multicolumn{2}{|l|}{ Ems estuary } & & -0.5 & Salomons \& Mook (1981) \\
\hline \multicolumn{5}{|l|}{ Suspended matter } \\
\hline Nieuwe Waterweg (Rhine) & $15-18^{\mathrm{a}}$ & About -5.0 & About -1.0 & Salomons \& Mook (1981) \\
\hline Marine suspended matter & $11-18^{a}$ & -4.4 to -3.2 & About 0.0 & Salomons \& Mook (1981) \\
\hline \multicolumn{5}{|l|}{ Geological sediments } \\
\hline Late Saalian lake sediments & $10-20$ & -4.0 to -6.0 & c. 0.0 & $\begin{array}{c}\text { Beets \& Beets (2003); } \\
\text { Beets et al. (2006) }\end{array}$ \\
\hline Late Saalian pool sediments & $5-10$ & -5.0 to -6.0 & c. 1.0 & $\begin{array}{c}\text { Beets \& Beets (2003); } \\
\text { Beets et al. (2006) }\end{array}$ \\
\hline Eemian lake sediments & $20-60$ & c. -4.2 & c. 3-1.5 and lower & $\begin{array}{c}\text { Beets \& Beets (2003); } \\
\text { Beets et al. (2006) }\end{array}$ \\
\hline \multicolumn{2}{|l|}{$\begin{array}{l}\text { Drente Formation in East } \\
\text { (the Netherlands) }\end{array}$} & $-0.5-1.5$ & $-0.5-1.5$ & Hartog et al. (2005) \\
\hline \multicolumn{2}{|l|}{$\begin{array}{l}\text { Breda, Oosterhout } \\
\text { Formation in East (the } \\
\text { Netherlands) }\end{array}$} & $0-2$ & c. 0 & Hartog et al. (2005) \\
\hline $\begin{array}{l}\text { Kreftenheije, Twente } \\
\text { Formation in East (the } \\
\text { Netherlands) }\end{array}$ & $\begin{array}{l}\text { Variable, presence of } \\
\text { siderite inferred }\end{array}$ & $-6-1$ & $-8-0$ & Hartog et al. (2005) \\
\hline $\begin{array}{l}\text { Waalre Formation in } \\
\text { Limburg }\end{array}$ & $\begin{array}{l}\text { Decimeter scale siderite } \\
\text { concretions }\end{array}$ & -4.8 to -2.3 & -10.2 & Vriens (2011) \\
\hline $\begin{array}{l}\text { Ice-pushed hills at northern } \\
\text { Gooi }\end{array}$ & Carbonated sandstone & Average -4.8 & Average -5.6 & Post (2006) \\
\hline $\begin{array}{l}\text { Boom Clay, outcrops in } \\
\text { Flanders (Belgium) }\end{array}$ & Calcite concretions & $-1-1$ & Mostly -22 to -18 & De Craen et al. $(1999 a, b)$ \\
\hline $\begin{array}{l}\text { Boom Clay, horizon S60, } \\
\text { Flanders (Belgium) }\end{array}$ & Siderite in concretion & 2.5 to 5 & Mostly -21 to -19 & $\begin{array}{l}\text { Laenen \& De Craen } \\
\qquad(2004)\end{array}$ \\
\hline
\end{tabular}

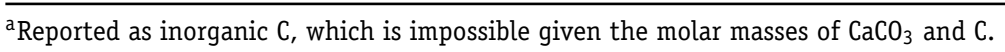

all fluvial deposits in the study area were calcareous at the time of sedimentation. In the course of tens of thousands of years the Middle Pleistocene Sterksel Formation was decalcified at regional scale below infiltration areas but not completely towards the exfiltration areas (i.e. the brook valleys). As a result, the depth of decalcification varies considerably at the regional scale: sediment from drillings down to about $100 \mathrm{~m}$ depth can be essentially non-calcareous. The coarse sands of the Beegden Formation that were deposited on top of this formation in part of the area were also strongly decalcified. The young Kreftenheye Formation overlying these sands is still dominantly calcareous because of its limited age and hydrogeological position close to the present river Meuse, i.e. on the downstream side of groundwater systems. Holocene channel belt deposits along the ice-pushed hills of Nijmegen and Montferland have also become decalcified by exfiltration of acid, $\mathrm{CO}_{2}$-rich groundwater that is unsaturated for calcite (Pons, 1957). This is a related mechanism acting at a shorter time scale and over smaller areas.

A third decalcification mechanism proposed by Smittenberg et al. (1998) is calcite dissolution in conjunction with siderite precipitation under palaeohydrological conditions. One may wonder whether this recrystallisation occurs immediately below infiltrating areas or in parts of groundwater systems further downstream. The Fe(II)-rich and calcite undersaturated groundwater that is a prerequisite for this process is unlikely for groundwater infiltration areas under palaeohydrological conditions: Griffioen et al. (2013) observed that the highest Fe concentrations in the southern Netherlands are related to high $\mathrm{SO}_{4}$ 
Table 12. Overview of the original and present-day carbonate contents of soils derived from different fluvial sediment types of the Rhine and Meuse river systems in the eastern Netherlands (derived from Pons (1957)).

\begin{tabular}{|c|c|c|c|c|}
\hline \multirow[b]{2}{*}{ Sediment type } & \multicolumn{2}{|c|}{ Rhine system } & \multicolumn{2}{|c|}{ Meuse system } \\
\hline & Original & Present & Original & Present \\
\hline High river loam soils ${ }^{a}$ & Calcareous to rich & Non-calcareous, acid & & \\
\hline $\begin{array}{l}\text { Medium-high river } \\
\text { loam soils }\end{array}$ & Rich & $\begin{array}{l}\text { Non-calcareous (sometimes } \\
\text { at } 100 \mathrm{~cm} \text { depth) }\end{array}$ & & \\
\hline Low river loam soils & Rich & $\begin{array}{l}\text { Non-calcareous (sometimes } \\
\text { at } 100 \mathrm{~cm} \text { depth) }\end{array}$ & & \\
\hline Spill soils & Calcareous & Calcareous & Poor & Non-calcareous \\
\hline River bank soils & $\begin{array}{l}\text { Calcareous } \\
\text { (sometimes } \\
\text { poor) }\end{array}$ & Calcareous (sometimes poor) & Poor & Poor to non-calcareous \\
\hline $\begin{array}{l}\text { Pre-Roman channel } \\
\text { belt soils }\end{array}$ & Rich & Calcareous to non-calcareous & Poor & Non-calcareous, sometimes poor \\
\hline $\begin{array}{l}\text { Late and post-Roman } \\
\text { channel belt soils }\end{array}$ & Rich & Rich to calcareous & Poor & Poor to non-calcareous \\
\hline Backswamp soils & Poor & Poor to non-calcareous & Poor to non-calcareous & Non-calcareous \\
\hline
\end{tabular}

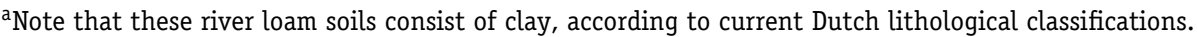

The boundary between 'poor' and 'rich' carbonate content is not explicitly defined but 'very poor' is written to be less than $0.5 \%$.

concentrations as result of enhanced atmospheric deposition and pyrite oxidation by extensive nitrate leaching. This applies to young groundwater under infiltration areas.

\subsection{Reactive Fe minerals: sulphides, oxyhydroxides, carbonates and phosphates}

4.5.1 Iron oxyhydroxides. Selective oxide extractions indicate the presence of Fe oxyhydroxides, where it must be remembered that other minerals may also dissolve to a certain extent in these extractants. Van den Berg et al. (1998) and Canavan and co-workers $(2006,2007)$ applied Fe oxide extractions to recent shallow sediments $(<0.4 \mathrm{~m})$ of the Biesbosch and Haringvliet, respectively (Table 13), where $\mathrm{SO}_{4}$ reduction was ongoing and thus anaerobic conditions prevailed. Using oxalate extraction, Van den Berg et al. (1998) measured 1-2\% $\mathrm{Fe}_{2} \mathrm{O}_{3}$ as amorphous Fe hydroxide rather invariant with depth. Canavan et al. $(2006,2007)$ found about $0.5 \%$ ascorbate-extractable $\mathrm{Fe}_{2} \mathrm{O}_{3}$ and $0.8-2.2 \%$ citrate-dithionite-bicarbonate-extractable $\mathrm{Fe}_{2} \mathrm{O}_{3}$ : the latter decreased more markedly within the depth profile. The presence of extractable Fe oxide at larger depth is attributed by Canavan et al. (2006) to the partial unavailability of chemically reducible Fe(III) for microbial respiration. Thomas (2007) found comparable average Fe oxide contents in recent, mostly sandy alluvial sediments of the Dommel and Dinkel brooks. The associated standard deviations were large, indicating a strong non-normal frequency distribution. The considerable difference in averages between the two brooks is noteworthy, as the grain size distributions were similar.
Selective Fe extractions were also applied by Buijs \& Van der Grift (2001) to samples collected anaerobically at approximately $160 \mathrm{~m}$ depth from the Pliocene Kieseloolite Formation in Limburg. The weak hydroxylamine extraction gave on average somewhat lower contents than the strong oxalate extraction: 0.2-0.4 wt $\% \mathrm{Fe}_{2} \mathrm{O}_{3}$ for the sand samples and 0.7-5.0 wt\% for the clay samples. The total $\mathrm{Fe}_{2} \mathrm{O}_{3}$ content (3-25\%) was also anomalously high in these clays, and respiration experiments revealed the presence of siderite. Secondary Fe enrichments were thus present in these clays. Two questions remain: whether true Fe oxides were extracted by the selective Fe oxide extractants, and how siderite interfered in these extractions.

A few studies have investigated Fe oxides in Dutch sediments in a direct, mineralogical manner. Riezebos (1971) and Riezebos et al. (1978) isolated opaque and subopaque grains from samples from terrace deposits and Holocene sediments of the river Meuse in southern Limburg and identified them by microscopy. Riezebos (1971) observed that $90 \%$ of the opaque grains were goethite or lepidocrite in old Pleistocene and younger Pleistocene terrace deposits (Kosberg and Geertruidenberg levels, respectively). These grains have diameters in the sand class range. The Holocene Meuse deposits revealed a similar high content of goethite in the opaque fraction (Riezebos et al., 1978). Goethite was present as detrital grains. Rutile made up about 5\% of the opaque grains and the remainder were ilmenite, leucoxene (finely crystalline rutile), magnetite and martite (pseudomorphic haematite). These minerals occurred as single grains and in rock fragments. Leucoxene and martite are weathering products under atmospheric conditions of ilmenite and magnetite, 
Table 13. Contents of extractable Fe oxyhydroxides and total Fe (as range or average with standard deviation) in recent sediments of fluviatile water systems.

$\left(\% \mathrm{Fe}_{2} \mathrm{O}_{3}\right)$

\begin{tabular}{|c|c|c|c|c|c|c|c|}
\hline Sampling site & Samples & Depth range $(\mathrm{cm})$ & Sampling & Fe oxide & Total Fe & Extractant & Reference \\
\hline Haringvliet west & 14 & $0-30 \mathrm{~cm}$ & Individual depth & $0.47-0.71$ & $2.8-4.7$ & Ascorbate & Canavan et al. (2006) \\
\hline Haringvliet west & 13 & $0-20 \mathrm{~cm}$ & Individual depth & $0.32-0.67$ & 4.7 & Ascorbate & Canavan et al. (2007) \\
\hline Haringvliet west & 13 & $0-20 \mathrm{~cm}$ & Individual depth & $0.8-2.2$ & 4.7 & $\mathrm{CDB}$ & Canavan et al. (2007) \\
\hline $\begin{array}{l}\text { Biesbosch wet- } \\
\text { land/floodplain }\end{array}$ & 50 & $10-20+30-40$ & Depth averaged & $1.0-1.9$ & & Oxalate & $\begin{array}{l}\text { Van den Berg et al. } \\
\text { (1998) }\end{array}$ \\
\hline Dommel river & 120 & $0-15$ & Depth interval & $1.30 \pm 2.03$ & $1.83 \pm 1.94$ & Oxalate & Thomas (2007) \\
\hline Dinkel river & 120 & $0-15$ & Depth interval & $0.20 \pm 0.22$ & $0.65 \pm 0.56$ & 0xalate & Thomas (2007) \\
\hline
\end{tabular}

$\mathrm{CDB}$, citrate-dithionite-bicarbonate extraction.

respectively. The Pliocene terrace deposits displayed a very different picture: the opaque minerals were dominated by rutile and leucoxene (70 and $20 \%$, respectively), with ilmenite as minor mineral. This composition shift was explained as an enlargement of the drainage area of the river Meuse at the beginning of Quaternary (Riezebos, 1971). Nelson \& Niggli (1950) isolated opaque and subopaque grains from Meuse deposits on the high terrace in northern Limburg and performed XRD analysis on them after pulverisation. This sample comprised ilmenite and rutile as opaque minerals. A high detrital goethite content is thus characteristic of Quaternary Meuse sediments (if the effects of diagenesis on goethite can be excluded). Ilmenite and rutile can be secondary minerals, but their occurrence as individual grains as well as rock fragments indicates that they were formed prior to fluvial transportation. The leucoxenisation of ilmenite was found to be different for the two types of ilmenite, which makes it unlikely that this happened postdepositionally under the hydrological conditions present in Limburg.

Zhang et al. (2012) used highly advanced spectroscopic techniques (sulphur K-edge X-ray near-edge structure and iron X-ray absorption spectroscopy) to characterise six Pliocene and Pleistocene fluvial samples from the Peel Horst (northern Limburg) according to reactive Fe minerals. As expected, the relative amount of Fe(III) oxides decreased with depth in favour of the amount of pyrite. Iron(II) oxides were substantially present in five out of six samples, which might be attributed to magnetite. Three samples contained near-similar amounts of Fe(III) oxides and pyrite, which were situated in the nitrate reduction zone. It cannot be assured that these minerals were mutually present under natural conditions or due to enhanced denitrification following intensive nitrate leaching. Thompson et al. (1992) performed a rare study on the magnetic properties of several cores from boreholes across the southern Northern Sea, one of which extended down to $220 \mathrm{~m}$ below the sea bed in Dutch territory. The measurements indicate the presence of magnetite as large grains in predominantly fluvial sediments and smaller grains probably of greigite or titanomagnetite in predominantly marine deltaic sediments. It is noteworthy that the magnetite had not diagenetically altered to Fe sulphides under buried, marine conditions in these sediments that were up to Pliocene age.

4.5.2 Rattle stones and iron oxyhydroxides. A particular occurrence of Fe oxides is as rattle stones in sandy or gravelly fluvial and periglacial deposits. Rattle stones are concretions composed of concentric laminae of different compositions, in which the core has become detached from the mantle. The cavity formed may be up to $50 \%$ volume. Van Loef (2000) studied their mineralogical and chemical composition in detail. Rattle stones were sampled near the Rhine and Meuse from pits in fluvial Sterksel and Kreftenheije deposits as well as periglacial Drente deposits, and were characterised using Mossbauer spectroscopy, XRD and instrumental neutron-activation analysis (INAA). Goethite was the predominant Fe oxyhydroxide in both core and mantle, and the crystallite size was in the nanometer range. Illite and vermiculite were the major clay minerals in the core and the Fe content varied from $2 \%$ to $15 \%$. The Fe content of the mantle was about $50 \%$ and decreased outwards with decreasing crystallinity of goethite. Lepidocrocite was identified in samples from the Kreftenheije and Drente Formations but not in those from Sterksel: this was attributed to slow transformation of lepidocrocite to goethite, as the Sterksel deposits date from the Middle Pleistocene and the other two from Late Pleistocene. Joosten (2004) reported that rattle stones from the Veluwe area are mainly composed of lepidocrite. The samples studied were collected from abandoned pits in the ice-pushed ridges, which suggests that they probably originate from the Middle Pleistocene Urk Formation. If this is true, it contradicts Van Loef's explanation of slow transformation (Van Loef, 2000): he suggested that lepidocrite would not be found in rattle stones of Middle Pleistocene age.

The genesis of these rattle stones has been debated. Loope et al. (2012) searched for analogues with concretions in Cretaceous sediments in Nebraska (USA). Van der Burg (1969) 
assumed that rattle stones were formed due to oxidation of allochthonous siderite concretions that were deposited with the sand or gravel in which they are found. 0xygen penetrated into the concretion and oxidatively dissolved siderite, whereas the mobilised Fe(III) precipitated as Fe oxide on the inner side of the dense, outer rim. Dissolved $\mathrm{CO}_{2}$ is produced during this reaction, which enhances the solubility of siderite. Because of differences in density, when siderite is converted into Fe oxide there is a loss in volume, which would have resulted in the void within the concretion. Van Loef (2000) assumes that the genesis is related to wetting-drying cycles of small clay layers within sandy sediments in groundwater-fed areas. He suggests that dissolved Fe(II) became oxidised and Fe oxides precipitated as the sediment dried, and the clay layer also fractured too. During repeated wetting-drying cycles, the core detached itself from the mantle upon drying out. The latter interpretation provides no mechanism for preferential transport of water and dissolved Fe(II) from the sandy sediment to the clay lens during a dry period and the assumed thickening of the rind outwards would result in the cementing of surrounding sand instead of clay (Loope et al., 2012). A more plausible explanation for the high porosities of the pores is a recrystallisation process, not desiccation of clay. Indeed, siderite concretions have been found in sand and gravel along the Meuse river near Venlo (Scheres, 2007), while these concretions are also known to be present in the surrounding Waalre clay layer (Westerhoff, 2009; Vriens, 2011). Van der Burg's explanation thus seems more likely to us.

4.5.3 Iron sulphides. AVS has been analysed by extraction on shallow sediments from lakes within the river Rhine system (Van den Berg et al., 2001; Van Griethuysen et al., 2003, 2004; Canavan et al., 2006, 2007), recent river sediments (Van den Berg et al., 1999; Poot et al., 2007; Thomas, 2007), floodplains (Poot et al., 2007) and temporarily inundated wetlands (Van den Berg et al., 1998; Table 14). AVS extractions have been interpreted in terms of non-pyritic reduced sulphur in the references cited. However, this sulphur may be attributed to aqueous $\mathrm{S}$ species, mackinawite, greigite, fine-grained pyrite or a combination of these four (Rickard \& Morse, 2005). The highest contents (up to $100 \mu \mathrm{mol} \mathrm{S} / \mathrm{g}$ ) were found in the western part of Haringvliet, where AVS amounts to almost $50 \%$ of total acid-soluble S. Contents up to $20 \mu \mathrm{mol} \mathrm{S} / \mathrm{g}$ were found in the other studies, where AVS usually account for less than $25 \%$ of total acid-soluble $\mathrm{S}$.

Depth-specific sampling has revealed that the sulphide content at the sediment/water interface is often but not always zero. Differences in the AVS contents observed have been attributed to differences in the depositional rates of sediment with a higher organic carbon content (which is a substrate for $\mathrm{SO}_{4}$ reduction) and more reduced conditions in areas of low hydrodynamic energy. Initial $\mathrm{SO}_{4}$ concentration does not appear to be a controlling factor. The early diagenesis of sulphides is hard to explain quantitatively by geochemical transport mod- elling of the S chemistry; the same applies to explaining the AVS contents as part of the total, aqua regia-soluble $S$ contents (Canavan et al., 2006, 2007).

Pyrite contents in fluvial sediments have mostly been determined by total elemental analysis, where either all total $S$ is assumed to be present as pyrite or it is calculated as the difference between total $S$ and AVS, and AVS is assumed to represent non-pyritic, reduced $S$ (see section 3.4). Table 14 presents AVS and total $S$ data for recent fluvial sediments. Except for most of the samples of Thomas (2007) and several riverine samples of Poot et al. (2007), the samples studied were clayey. The total S contents were usually several thousands of milligrams per kilogram and the AVS contents were much smaller. Following the assumptions made by the authors, the pyrite contents often vary between $0.1 \%$ and $1 \%$, as $1000 \mathrm{mg} \mathrm{S} / \mathrm{kg}$ is equivalent to $0.18 \%$ pyrite. A relevant question is how representative these values are for the pre-industrial period because human activities have caused $S$ to become mobilised in the environment. It is worth noting that both the $S$ content and the Fe oxide content (Tables 13 and 14) are lower in the Dinkel brook than in the Dommel brook and the Rhine river system. The presence of reactive Fe minerals thus varies regionally within the Dutch surface water systems.

Griffioen et al. (2012) present cumulative frequency distributions per lithological class for shallow geological formations ( $<30 \mathrm{~m}$ depth) in the Roer Valley Graben and the Holland area that were mostly fluvial. Several observations are worth mentioning. First, these distributions are frequently concave, i.e. many samples with low content and a small group of samples with high contents. Second, the clay class has higher pyrite contents than the sand class, except for the Upper Pleistocene Kreftenheije Formation in Holland: the contents are commonly below $1 \%$ in sand and run up to $1-8 \%$ in clay. Third, statistically significant differences between the frequency distributions were found between the sand groups but not between the clay groups. Table 8 presents an overview of pyrite contents for several geological formations characterised in different regions following a similar approach to that of Griffioen et al. (2012). Another general observation is that the maximum values are frequently three or more times higher than the 90 percentiles, which underlines the concave nature of the cumulative frequency distributions and the frequent existence of outliers. The sediment petrological origin of these outliers is not clear. It is worth pointing out that the pyrite contents of the Kreftenheije and Echteld Formations in the riverine area are about as high as those found in the western Holland area, where $\mathrm{SO}_{4}$-rich marine groundwater would have been more abundant during the Holocene. It seems that the presence of seawater-derived groundwater was not the limiting factor in pyrite diagenesis for these formations (Van Helvoort et al., 2005, 2007).

By means of factor analysis on geochemical data of Holocene fluvial sediments from the riverine area, Van Helvoort et al. (2005) found that sulphur was associated with sedimentary 
Table 14. Sulphur contents (as range or average with standard deviation) in different kinds of recent sediments in fluvial systems or small pools and lake.

\begin{tabular}{|c|c|c|c|c|c|c|c|}
\hline Sampling site & Samples & $\begin{array}{l}\text { Depth range } \\
\text { (cm) }\end{array}$ & Sampling & $\begin{array}{l}\text { AVS } \\
(\mathrm{mg} / \mathrm{kg})\end{array}$ & $\begin{array}{l}\text { Total S } \\
(\mathrm{mg} / \mathrm{kg})\end{array}$ & $\begin{array}{l}\text { Method for } \\
\text { total S }\end{array}$ & Reference \\
\hline \multicolumn{8}{|l|}{ Fluvial systems } \\
\hline Lake Ketel & 40 & $0-15$ & Individual depth & $0-480$ & Not reported & - & Van den Berg et al. (2001) \\
\hline Dommel basin - river & 12 & $0-5$ & Temporal average of 2 & $0-448$ & $105-4605$ & Aqua regia & Poot et al. (2007) \\
\hline Dommel basin - floodplain & 8 & $0-5$ & Temporal average of 2 & $64-704$ & $2915-7590$ & Aqua regia & Poot et al. (2007) \\
\hline Lake in River Waal floodplain & 24 & $0-5$ & Depth averaged & $490 \pm 314$ & $1919 \pm 402$ & Aqua regia & Van Griethuyzen et al. (2003) \\
\hline Lakes in floodplains of Rhine, Waal and Ijssel & 40 & $0-5$ & Depth averaged & 49-1560 & $126-8427$ & Aqua regia & Van Griethuyzen et al. (2004) \\
\hline Haringvliet west & 18 & $0-30$ & Individual depth & $0-3200$ & $1920-6400$ & Carbon/sulphur analysis & Canavan et al. (2006) \\
\hline Haringvliet west & 15 & $0-20$ & Individual depth & $0-2560$ & $2500-9000$ & Carbon/sulphur analysis & Canavan et al. (2007) \\
\hline Biesbosch wetland/floodplain & 6 & $10-20$ and $30-40$ & Depth averaged & $0-227$ & Not analysed & - & Van den Berg et al. (1998) \\
\hline Biesbosch aqueous sediment/Meuse & 50 & $0-10$ & Individual depth & 20 (to $640 / 1920$ ) & Not analysed & - & Van den Berg et al. (1999) \\
\hline Dommel brook & $120 / 16$ & $0-15$ & $3 \mathrm{~cm}$ intervals & 240 & $2597 \pm 5151$ & Carbon/sulphur analysis & Thomas (2007) \\
\hline Dinkel brook & 120 & $0-15$ & $3 \mathrm{~cm}$ intervals & Not analysed & $317 \pm 515$ & Carbon/sulphur analysis & Thomas (2007) \\
\hline \multicolumn{8}{|l|}{ Isolated pools and lake } \\
\hline Gerritsfles pool & 10 & $0-20$ & $2 \mathrm{~cm}$ intervals & $22-288$ & $480-8000^{\mathrm{a}}$ & $\mathrm{HNO}_{3}$ after $\mathrm{HF}$ removal & Marnette et al. (1993) \\
\hline Kliplo pool & 10 & $0-20$ & $2 \mathrm{~cm}$ intervals & $80-22$ & $480-3200^{\mathrm{a}}$ & $\mathrm{HNO}_{3}$ after $\mathrm{HF}$ removal & Marnette et al. (1993) \\
\hline Lake Vechten & 8 & $0-9$ & $1 \mathrm{~cm}$ intervals & \pm 2400 & \pm 4000 & $\mathrm{HNO}_{3}-\mathrm{HClO}_{4}$ & Hordijk et al. (1989) \\
\hline
\end{tabular}

${ }^{\mathrm{a} A s}$ pyrite-S. 
organic matter content. Similar findings were reported by Heerdink \& Griffioen (2012) and Vermooten et al. (2011) for various geological formations present within $30 \mathrm{~m}$ depth in the northern Netherlands and Zeeland. These regional observations are in line with the microscopic observations of Van den Berg et al. (1998) and Huisman (1998) on the association between $S$ and organic matter. Van Helvoort (2003) and Van Helvoort et al. (2007) found that for different sedimentary facies within the Holocene fluvial sediments the pyrite content is not dictated solely by lithological class (Table 10). The pyrite content decreased in the following order for the reduced series of samples: peat $>$ calcareous inland dune $\cong$ flood basin clay $>$ crevasse/levee $>$ decalcified inland dune $\cong$ channel. The oxidised samples had pyrite contents at or below detection limit. This shows that the major controlling factors on pyrite content are not depositional sorting but peat formation together with post-depositional diagenesis and leaching. The highest contents are also not necessarily related to the clay class.

Using an electron microprobe technique, Van den Berg et al. (1998) noted that in recent sediments sulphide precipitates had a 1:1 molar ratio for Fe to $S$, where all Fe sulphide was associated with the presence of vascular cell structures. Such precipitates may be related to the original presence of Fe oxide precipitates on the root surface plus the decomposition of proteins in reed roots associated with $\mathrm{SO}_{4}$ reduction. Huisman et al. (2000) and Huisman (1998) found that pyrite occurs as framboids of 10-50 $\mu \mathrm{m}$ (Fig. 5), irregular concentrations up to $5 \mathrm{~mm}$ or nodules of $0.5-2 \mathrm{~cm}$ diameter in Late Pliocene and Early Pleistocene fluvial sediments: large amounts were concentrated in organic-rich clay layers $\left(5-15 \% \mathrm{C}_{\text {org }}\right.$ ) of a few tens of centimetres thick within the clay deposits. The pyrite was microscopically either associated with organic matter or occurred as loose or complete infillings in cracks. Based on the micromorphological presence of illuviated clay in these cracks, Huisman and co-authors proposed that these S-rich, fluvial deposits (up to $5 \% \mathrm{~S}$ ) had been subjected to marine or brackish influence postdepositionally. This is palaeogeographically debatable for these samples from Limburg (Westerhoff, 2009). Rijksgeologische Dienst (RGD; 1989) also noted small framboidal pyrite in clay sublayers of shallow ( $<35 \mathrm{~m}$ ) Pleistocene Meuse deposits and in clay and sand of Pliocene Kieseloolite deposits on the Peel Horst. No bigger aggregates were observed in either of these deposits.

Table 8 presents statistical data on the 'reactive Fe other than pyrite' contents of fluvial, stratigraphical formations. These amounts cannot be said to be equal to the Fe oxide contents because siderite, vivianite and possibly glauconite may also be involved. As expected, the contents are higher in clay and loam than in sand. The contents in clay and sand vary around several per cent, which is comparable to the Fe oxide contents in recent fluvial sediments (Table 13). The median values in sand are consistently below detection limit, which indicates there are negligible amounts of the related minerals in these geological units. High contents are found in the riverine area (Echteld and Kreftenheije Formations) and the Waalre Formation (particularly on the Kempen Plateau). The mineralogical speciation of this reactive Fe is still enigmatic for Dutch sediments. Occasional findings by Huisman and Kiden (1998) using $\mathrm{XRD}$ and scanning electron microscopy (SEM) indicated that Fe enrichments occur mostly as siderite in the Waalre Formation and as oxyhydroxides in the Pliocene Kieseloolite Formation. These findings apply to sediments buried below $20 \mathrm{~m}$ depth, where groundwater is probably Fe anoxic. We presume that $S$ was limiting for more complete pyritisation of total reactive Fe in these buried fluvial sediments.

4.5.4 Iron carbonate. Traces of siderite have been reported in the silt and clay fraction of suspended material of the Rhine and also the German Ems and Belgium Scheldt Rivers (Crommelin, 1943; Wartel, 1977). Siderite is regularly found in fluvial deposits under different sedimentological conditions, but the mineralogical matrix is always almost completely devoid of vivianite and pyrite. It occurs in three situations.

First, siderite is found in finely laminated clay and silt layers of the Waalre Formation (Huisman \& Kiden, 1998; Smittenberg et al., 1998; Westerhoff, 2009; Vriens, 2011; Fig. 6). It appears as: (1) coating of Ca-rich siderite on dolomite grains, (2) nodules of Ca-rich microcrystalline siderite, 2-40 $\mu \mathrm{m}$ in diameter, (3) sand to silt sized carbonate concretions with $\mathrm{Ca}, \mathrm{Mg}$ and Fe in varying ratios (4) concretions of several decimetres in diameter and (5) a gel. Vriens (2011) studied the large concretions in more detail using XRD and observed calcite, siderite and a carbonate solid solution with a chemical formula of $\mathrm{Ca}_{0.1} \mathrm{Mg}_{0.33} \mathrm{Fe}_{0.57} \mathrm{CO}_{3}$. The large concretions show variable $\mathrm{Fe}$ and Ca contents from the centre to the rim, but without a clear trend. This is opposite to what has been found for carbonate concretions in the marine Boom Clay containing ferroan calcite (De Craen et al., 1999a; Laenen \& De Craen, 2004). Smittenberg et al. (1998) supposed that siderite was formed postdepositionally under waterlogged conditions, when carbonate originating from dissolution of calcite reacted with Fe(II) supplied by groundwater and/or weathering mica. Vriens (2011) found for siderite rather depleted $\delta^{18} 0$ and $\delta^{13} \mathrm{C}$ values of -2 to $-5 \%$ and $-10 \%$, respectively, and for $\mathrm{Ca}$ carbonate only depleted $\delta^{13} \mathrm{C}$ values of -6 to $-7 \%$ in the concretions, which implies that straightforward reprecipitation of $\mathrm{Ca}$ carbonate to siderite cannot explain the diagenesis of siderite.

The second situation in which siderite is found is when it has formed under early diagenetic conditions in Late Pleistocene or Holocene gyttja deposits in association with vivianite and S (as pyrite or organically bound; Smittenberg et al., 1998). Such gyttja deposits can be found as infillings in oxbow lakes within a fluviatile environment. The siderite results from decay of organic matter under methanogenic, freshwater conditions, which supply the bicarbonate, with an influx of Fe(II) dissolved in groundwater. As mentioned earlier, calcite may also form 

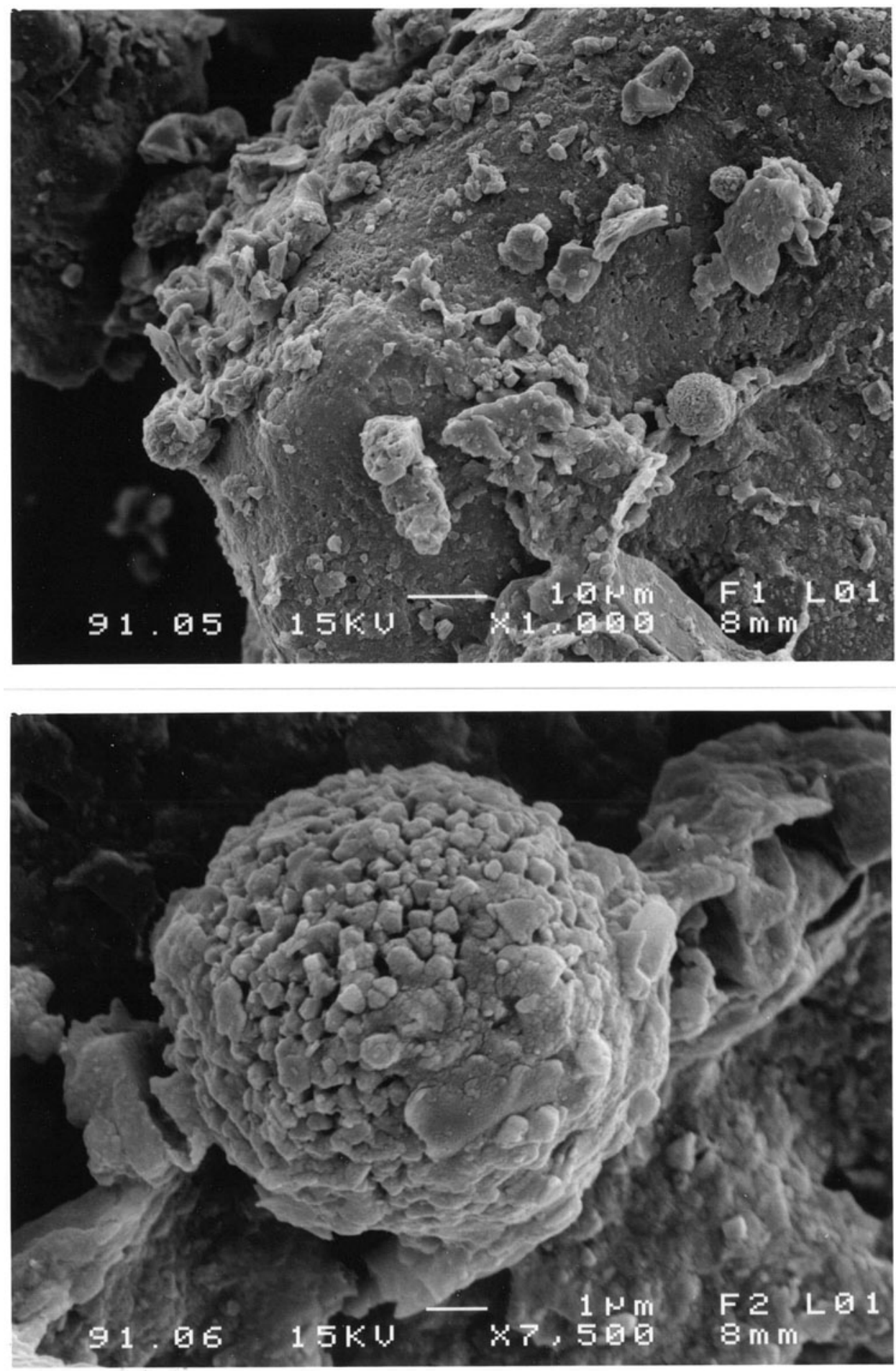

Fig. 5. Example of pyrite framboids adhered to a sand grain (above) and the micromorphology of a single framboid (below).

here. The carbonate was found as subangular concentric nodules of calcite and siderite. XRD analysis confirmed that the nodules occurred as a mixture of calcite and siderite instead of single ankerite. The latter is a mixed carbonate that can form under low-grade metamorphic or hydrothermal conditions (Deer et al., 1966).
Third, siderite seems to be dispersed in anoxic aquifer sediments (Hartog et al., 2002, 2005). Its presence is inferred from $\mathrm{CO}_{2}$ to $\mathrm{O}_{2}$ ratios produced during incubation experiments on aquifer sediment samples as well as depleted $\delta^{13} \mathrm{C}$ values for carbonate present in aquifer sediments (Table 11). A series of samples from the fluvial Late Pleistocene Kreftenheije Formation 
Fig. 6. Whitish siderite-rich layer in clay of the Waalre Formation in the Maalbeek quarry (near Venlo, Limburg).

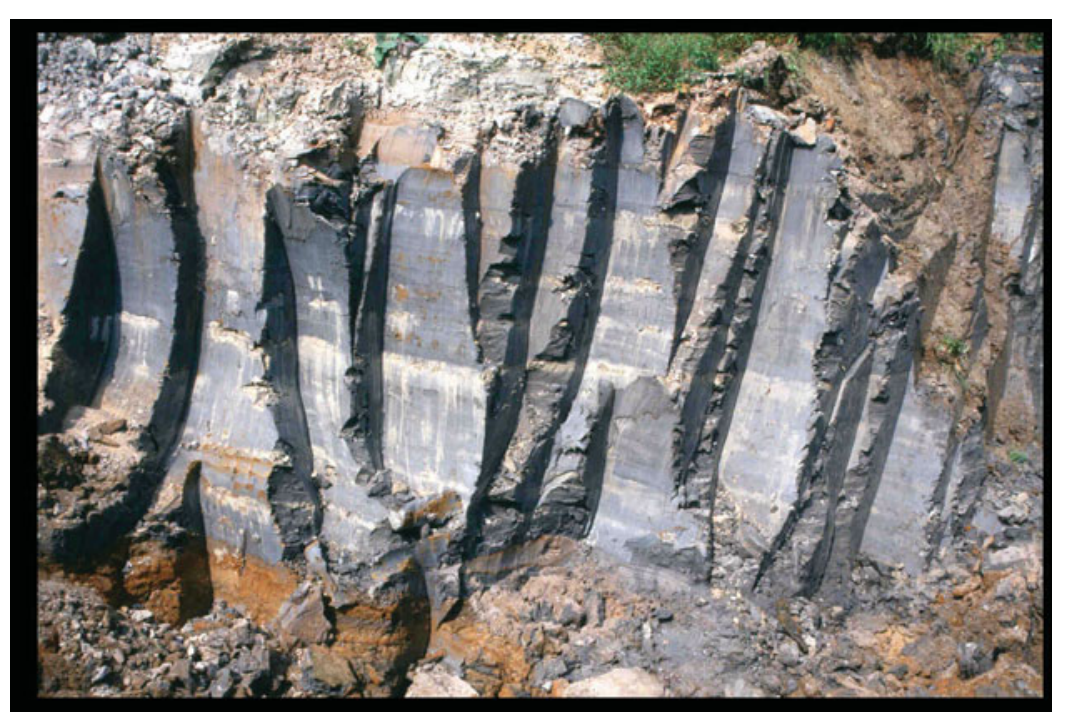

as well as periglacial Drente Formation show $\delta^{18} 0_{\text {carb }}$ values as low as $-3 \%$ and $\delta^{13} C_{\text {carb }}$ values even as low as $-8 \%$. Borehole descriptions in which siderite is visually observed also point to the widespread occurrence of siderite in Dutch aquifer sediments. Hemel \& Stuurman (1999) deduced that the upper $40 \mathrm{~m}$ of the Roer Valley Graben area are siderite-free, except occasionally in the vicinity of the eastern and western faults at 20-50 m depth. Below $40 \mathrm{~m}$, siderite is found within the Roer Valley Graben and its occurrence corresponds with that of Ca carbonate. However, borehole data on siderite are less numerous than those on $\mathrm{Ca}$ carbonate.

4.5.5 Other reactive Fe minerals. Two studies using selective extraction, one with additional microprobe analysis, concluded that ferric $\mathrm{Fe}$ and $\mathrm{PO}_{4}$ can be bound in an almost fixed molar ratio of 1.2 to 1.5 as a mineral phase instead of $\mathrm{PO}_{4}$ being sorbed or co-precipitated with Fe hydroxide (Van Eck, 1982a,b; Hyacinthe \& Van Cappellen, 2004). Earlier, Nriagu \& Dell (1974) had pointed out that tinticite, $\mathrm{Fe}_{3}\left(\mathrm{PO}_{4}\right)_{2}(\mathrm{OH})_{3} \cdot 3 \mathrm{H}_{2} \mathrm{O}$, or cacoxenite, $\mathrm{Fe}_{4}\left(\mathrm{PO}_{4}\right)_{3}(\mathrm{OH})_{3} \cdot 12 \mathrm{H}_{2} \mathrm{O}$, might control $\mathrm{PO}_{4}$ solubility in freshwater environments. Van Eck (1982a,b) studied suspended matter in Haringvliet and Hollands Diep. Hyacinthe \& Van Cappellen studied recent fresh estuarine sediment of the Scheldt in Belgium and recent brackish estuarine sediment of the Western Scheldt. They found $\mathrm{Fe}$ (III) $\mathrm{PO}_{4}$ aggregates typically several tens of microns in size for both sites, with Mn co-occurring as a minor cation with an Fe to Mn molar ratio of about 10. In both the fresh sediment (Hyacinthe \& Van Cappellen, 2004) and the suspended matter (Van Eck, 1982a,b) all reactive Fe was bound to $\mathrm{PO}_{4}$, whereas in the brackish sediment only about half of the reactive Fe was bound, leaving some reactive Fe for other solid components.

The Weerdinge Member of the Appelscha Formation is the only Dutch geological unit of fluvial origin for which glauconite has been systematically observed in small amounts (www.dinoloket.nl). The formation predominantly contains coarse sand with some gravel.

4.5.6 Redox reactivity. Incubation experiments on Dutch sediment samples showed that pyrite and siderite, together with sedimentary organic matter, are important reductants for oxidants entering aquifer sediments via groundwater flow (Hartog et al., 2002, 2005; Van Helvoort et al., 2007). The three reductants may react in parallel when the sediment is exposed to dissolved oxygen. The preferential oxidation during the experiments revealed that by comparison with sedimentary organic matter, the pyrite was more reactive but siderite reacted more sluggishly. Field studies have shown that pyrite oxidation leads to denitrification of nitrate-rich groundwater under farmland at the regional scale in the southern and eastern Pleistocene parts of the Netherlands (Van Beek \& Hettinga, 1989; Griffioen \& Keijzer, 2001; Visser et al., 2009; Zhang et al., 2009). The rate of depyritisation can be roughly estimated analogously to the rate of decalcification, using similar figures for porosity and recharge rate. It takes 153 years for the depyritisation of one cubic metre of sediment containing $0.1 \% \mathrm{FeS}_{2}$ when the infiltrate contains $50 \mathrm{mg} \mathrm{NO} / \mathrm{l}$ (the international drinking water limit) and no oxygen is involved in the depyritisation. This rate implies that extensive nitrate leaching due to intensification of agriculture since World War II has not resulted in regional-scale depyritisation of Dutch groundwater aquifers. The redox cline within an aquifer from suboxic, pyrite-free to anoxic, pyrite-bearing may have shifted a few metres in the past 60 years but not tens of metres. Locally, Van Helvoort et al. (2007) could also distinguish oxidised, pyrite-poor and reduced pyrite-bearing sedimentary facies within the Holocene confining layer in the riverine area. The pyrite-poor facies occurred mainly in the upper 1-1.5 m, suggesting that pyrite has leached in historical time, triggered by anthropogenic drainage, whereas previously pyrite had been produced in an early post-depositional stage. If 
the leaching occurs under more open conditions with respect to oxygen, due to artificial drainage, the rate of depyritisation will be higher for the same pyrite content than the rate presented above.

\subsection{Solid organic matter}

4.6.1 Organic matter contents. Table 15 presents summarising data on organic $C$ contents in suspended matter and recent sediments from diverse fluvial systems. In 1995 there was an extremely high peak flow for the Rhine and Meuse rivers. Suspended matter and sediment deposited during the resulting floods contained around 6-11\% organic C (Wolterbeek et al., 1996; Koelmans, 1998). Floodplain sediments or aquatic sediments in floodplain lakes have contents varying from close to detection limit to about 15\% (Wolterbeek et al., 1996; Van Griethuysen et al., 2003, 2004; Vijver et al., 2008). The organic carbon contents associated with present-day or young material from the large rivers are thus generally substantial. Wolterbeek et al. (1996) noted that for the Waal and Meuse river systems the organic $C$ in the 1995 flood sediment was about twice that of the content in the topsoil below, and somewhat less than that of the Rhine river system. This suggests that not only the suspended matter content increases with increasing discharge (Asselman, 1999), but so does the organic C content. The aquatic sandy sediments in the brooks of the Dommel and Dinkel catchments have low organic C (Thomas, 2007).

Table 8 presents statistical data on the organic carbon content of various fluvial geological formations in different regions. The median values are often below or close to the detection limit (which is approximately $0.1 \%$ ) except for clay in the Echteld Formation and clay and loam in the Tijnje Member of the Urk Formation. The high percentile values also become substantial in sand of the Echteld Formation. The Holocene Echteld Formation thus contains more sedimentary OM than the Pleistocene Formations studied. Whether this is an intrinsic characteristic of the sediments or a result of less prolonged 0M degradation cannot be ascertained.

4.6.2 Carbon isotopes. The isotopic composition of particulate organic matter in recent sediments and suspended matter close to the mouths of the large rivers was studied by Salomons \& Mook (1981) and Laane et al. (1990) (Table 16). The data show that the organic matter in the fluvial systems is predominantly land-derived material and old organic matter is present, for example 65 PMC is equivalent to a radiocarbon age of 3560 years. The suspended organic matter from the Rhine has somewhat lower $\delta^{13} \mathrm{C}$ values than the sedimentary organic matter. Middelburg and Herman (2007) found that by comparison, suspended organic matter from the Meuse had somewhat lower $\delta^{13} \mathrm{C}$ values; Hellings et al. (1999) found seasonally fluctuating $\delta^{13} \mathrm{C}$ values between -32 and $-27 \%$ for the upstream, fresh part of the Zeeschelde in Belgium. This suggests that more riverine algae or its detritus is present in the Meuse and the Scheldt than the Rhine. The $\delta^{13} \mathrm{C}$ values of sedimentary $\mathrm{OM}$ in a series of fluvial as well as marine and fluvioglacial deposits were determined by Hartog et al. (2005). They found an average of $-25.1 \%$ o \pm 1.1 irrespective of geological formation or depth (Table 15). These values attest to the dominance of terrestrially derived $0 \mathrm{M}$.

4.6.3 Organic geochemistry. Tambach et al. (2009) characterised the bulk chemical properties of sedimentary organic matter in a small series of Early Holocene and Late Pleistocene fluvial sediments, using Rock-Eval pyrolysis. Here, the results for the unpurified samples will be summarised. The clastic samples from below the soil contained $55 \%$ to almost $80 \%$ refractory organic matter: the remainder was pyrolisable organic matter. For the latter, both the generation of hydrocarbons and $\mathrm{CO} / \mathrm{CO}_{2}$ were recorded as a function of increasing pyrolysis temperature. This bulk characterisation illustrates that $0 \mathrm{M}$ in aquifer sediment contains mostly refractory (inert) compounds.

More detailed molecular analysis of organic matter in suspended matter, recent sediments and geological deposits, all fluvial in nature, was performed by Van de Meent et al. (1980, 1985) and Hartog et al. (2005) using pyrolysis-MS with or without GC. Additionally, Hartog et al. $(2004,2005)$ studied Pleistocene glacial and Neogene marine deposits. It should be remembered that this method is basically semi-quantitative: an unresolved complex mixture of unidentified compounds is present and when samples are prepared using $\mathrm{HCl} / \mathrm{HF}$ treatment, some OM is lost. Van de Meent et al. (1980, 1985) analysed samples from Lake IJsselmeer/Lake Ketelmeer and Haringvliet/Hollands Diep for the dominance of carbohydrates (including polysaccharides), proteins, lignin and peptides. The samples were taken in 1978, when algal blooms were abundant and eutrophication of these water bodies was much more severe than in the geological past or nowadays. For suspended matter they found a downstream increase in algae or bacterial biomass contribution that was probably the result of sedimentation of lignin-rich suspended $0 \mathrm{M}$ in the upstream parts of these water bodies. They also found that $\mathrm{OM}$ in recent sediments contained more lignin compared to the $0 \mathrm{M}$ in the suspended matter in the overlying water column. The difference is attributable to selective preservation of the refractory lignin-based compounds during settling and mineralisation. Similar findings were deduced from carbon isotopic analyses as described above.

A striking observation of Hartog et al. (2004, 2005) was that all fluvial, marine and glacial deposits were dominated by terrestrially derived $0 \mathrm{M}$, whereas in the marine 0osterhout samples no compounds of unequivocal marine origin were observed. This is in agreement with the stable carbon isotope analyses (Table 15). The interpretation was further based on four classes of compounds: (1) lignin-derived compounds (mainly guaiacyl based), (2) long-chain aliphatics, (3) fatty acids and (4) hopanoids. The presence of guaiacyl components, aromatics and long-chain alkanes with odd-over-even predominance 
Table 15. Organic carbon contents (as range or average with or without standard deviation) in recent sediments in fluvial systems or related floodplains.

\begin{tabular}{|c|c|c|c|}
\hline Location - recent sediments & Sampling interval & C organic (wt\%) & Reference \\
\hline Flood 1995 sediments (Rhine-Meuse-Waal) & Thin layer & 7.0-11.1 (means) & Wolterbeek et al. (1996) \\
\hline Floodplain (Rhine-Meuse-Waal) & $10-15 \mathrm{~cm}$ depth & $4.3-8.9$ (means) & Wolterbeek et al. (1996) \\
\hline Lakes in floodplains of rivers Rhine, Waal and Ijssel & $5 \mathrm{~cm}$ depth & $0.2-16$ & Van Griethuysen et al. (2004) \\
\hline Dommel river - recent sediment & $5 \mathrm{~cm}$ depth & $0.2-0.75$ & Poot et al. (2007) \\
\hline Dommel river - floodplain sediment & $5 \mathrm{~cm}$ depth & $17-41$ & Poot et al. (2007) \\
\hline Dommel river system & $0-15 \mathrm{~cm}$ & $2.4 \pm 3.6$ & Thomas (2007) \\
\hline Dinkel river system & $0-15 \mathrm{~cm}$ & $0.7 \pm 1.4$ & Thomas (2007) \\
\hline Waal floodplain & $0-5$ and $5-10 \mathrm{~cm}$ & $0.15-13($ median $=5)$ & Vijver et al. (2008) \\
\hline Lake in river Waal floodplain & $5 \mathrm{~cm}$ depth & $5.6 \pm 0.6$ & Van Griethuyzen et al. (2003) \\
\hline Lake Ketelmeer & Down to $14 \mathrm{~cm} \max$. & $1.9-5.3$ & Van den Berg et al. (2001) \\
\hline
\end{tabular}

reflects the importance of plant debris, while the absence of carbohydrate-based products indicates that degradation of the more labile substances of plant-derived OM (and also of phytoplankton) has occurred. The presence of guaiacyl compounds with or without preserved side-chains indicates the different intensity of oxidation among the samples: the fluvial Kreftenheije and periglacial Twente (now part of the Boxtel Formation) sand samples were almost depleted of guaiacyl components. No hopanoid-derived compounds were observed in these two samples either. A small input of bacterial hopanoids was observed in all other samples: this indicates the presence of dead bacterial biomass. Further, the odd-over-even predominance of the long-chain $n$-alkanes was most pronounced in these two samples, as was the aliphatic signal derived from macromolecular structures versus that from the 'free' low-molecular-weight compounds. Thus, although these samples were geologically the youngest studied, they exhibited the most advanced degradation of sedimentary 0M. Hartog et al. $(2004,2005)$ therefore concluded that sediment age is in itself not the dominant factor controlling the degradation status of sedimentary $0 \mathrm{M}$. The difference between a clay sample and a sand sample (both from the Kreftenheije Formation, where the clay has a better preserved OM status), reveals that the source cannot be the dominant control. A major controlling factor seems to be the duration that sediments were exposed to oxygen.

\section{Marine and estuarine sediments}

The marine geological deposits comprise the Holocene Naaldwijk Formation, the Late Pleistocene Eem Formation, the Early Pleistocene Maassluis Formation and a continuous series of Palaeogene and Neogene formations (Fig. 4). They are widespread in the Netherlands and the adjacent Dutch part of the North Sea. During the Quaternary, they were deposited in relatively short periods in the onshore part of the Netherlands. The most western deposits of the Early Pleistocene Waalre Formation and the most northwestern deposits of the Middle Pleistocene Urk For- mation are also estuarine, although these formations are basically fluvial deposits from the Rhine system. In addition to these buried deposits, recent sediments on the tidal flats and beaches have frequently been studied, as has suspended sediment, particularly in the Scheldt estuary. For the sake of completeness, the mineralogical literature on the Belgian part of the Scheldt estuary has been reviewed as well. Fig. 7 presents a map of the southern North Sea with all geographical names used in this paper.

\subsection{Heavy minerals}

5.1.1 Seabed sands in the southern North Sea. Baak's (1936) study of the heavy minerals of seabed sands in the southern North Sea was intended as a continuation and expansion of the pioneering studies by Edelman (1933; see section 4.1). In total, Baak studied nearly 1000 samples and distinguished five HMAs (Table 17) that individually or as a mixture characterise the North Sea seabed sediments. For the distribution of the HMAs, see Fig. 8.

The interpretations of Baak and later heavy mineral studies on the origin of the sands (Steinert, 1948; Eisma, 1968; Ludwig \& Figge, 1979; Henningsen, 1987, Schwartz, 1996) were compared by Schüttenhelm \& Laban (2005) with the results of recent seabed sediment mapping and sediment dynamics in the southern North Sea. Their findings for the five HMAs distinguished by Baak are summarised below:

- A group: with green hornblende, epidote and bright and colourless garnet. This group is identical to Edelman's A group (section 4.1). Geographically, this group is located along the German and Danish coast but also north and southeast of Dogger Bank and off Lowestoft (Fig. 8). All samples from deep boreholes in the German, Danish and Dutch sectors belong to this A association (Schwartz, 1996). Baak interpreted this A group as having a northern Scandinavian provenance and as being formed during most of the Quaternary. This fits very well with the mapped fluvial and glacial 
Table 16. Observed ranges or averages with standard deviations in organic matter content and its $\delta^{13} \mathrm{C}$ and ${ }^{14} \mathrm{C}$ values for suspended matter and recent sediments in fluvial, estuarine and marine systems.

\begin{tabular}{|c|c|c|c|c|c|}
\hline $\begin{array}{l}\text { Sediment type } \\
\text { and location }\end{array}$ & $\begin{array}{l}\text { Sampling } \\
\text { period }\end{array}$ & $\begin{array}{l}\text { C organic } \\
(w t \%)\end{array}$ & $\begin{array}{l}\delta^{13} \mathrm{C} \text { organic } \\
(\% \text { PDB) }\end{array}$ & $\begin{array}{l}{ }^{14} \mathrm{C} \text { organic } \\
\text { (PMC) }\end{array}$ & Reference \\
\hline \multicolumn{6}{|l|}{ Recent sediments } \\
\hline Fluvial Rhine, Meuse & & 4 to 8 & -26 to -25 & 65.1 and 91.4 & Salomons \& Mook (1981) \\
\hline Fluvial Ems, Scheldt & & 4 to 10 & -28 to -27 & & Salomons \& Mook (1981) \\
\hline $\begin{array}{l}\text { Hollands Diep/Haringvliet } \\
\text { (Rhine) }\end{array}$ & Prior to closing! & 4 to 7 & c. -25 & & Salomons \& Mook (1981) \\
\hline Nieuwe Maas (Rhine) & & & -27 to -22 & & Laane et al. (1990) \\
\hline Coastal marine & & 2.3 to 4.3 & -25 to -20 & 48.0 to 83.9 & Salomons \& Mook (1981) \\
\hline Coastal marine (Dutch) & & 0.023 to 0.51 & -21.9 to -21.9 & & Dauwe \& Middelburg (1998) \\
\hline Central North Sea - mud & & $1.47 \pm 0.81$ & & & Wiesner et al. (1990) \\
\hline Central North Sea - sand & & $0.05 \pm 0.02$ & & & Wiesner et al. (1990) \\
\hline $\begin{array}{l}\text { Central North Sea - } \\
\text { heteroclastic }\end{array}$ & & $0.16 \pm 0.10$ & & & Wiesner et al. (1990) \\
\hline Ems estuary & & 4 & c. -25 & & Salomons \& Mook (1981) \\
\hline Zeeschelde (B) - "upper" & & & $-26.3 \pm 1.0$ & & $\begin{array}{l}\text { Middelburg \& Nieuwenhuize } \\
\text { (1998) }\end{array}$ \\
\hline Westerschelde & $1985 ?$ & & $-23.8 \pm 4.1$ & & Laane et al. (1990) \\
\hline Westerschelde - "lower" & & & $-23.5 \pm 1.0$ & & $\begin{array}{l}\text { Middelburg \& Nieuwenhuize } \\
\text { (1998) }\end{array}$ \\
\hline Westerschelde at Waarde & & 0.7 to 1.8 & -25.7 to $-22.2(\mathrm{avg})$ & & Boschker et al. (1999) \\
\hline Oosterschelde at Kattendijke & & 0.2 to 0.4 & $-20 \pm 1.4 / 0.3$ & & Boschker et al. (1999) \\
\hline \multicolumn{6}{|l|}{ Suspended matter } \\
\hline Nieuwe Waterweg (Rhine) & & 4.6 to 6.8 & c. -27 & & Salomons \& Mook (1981) \\
\hline Nieuwe Maas (Rhine) & & & -27.5 to -25.5 & & Laane et al. (1990) \\
\hline Rhine River & & & -27.6 and -26.3 & & Middelburg \& Herman (2007) \\
\hline Meuse River & & $3-10$ & -30.5 and -28.1 & & Middelburg \& Herman (2007) \\
\hline Marine suspended material & & 6 to 13 & -25 to -20 and -15.2 & & Salomons \& Mook (1981) \\
\hline Marine suspended material & 1974-1982 & & & & Mariotti et al. (1984) \\
\hline Marine suspended material & $1993+1998$ & & -22 and -21 & & Chen et al. (2005) \\
\hline North Sea & March 1993 & 4 to 10 & & & Boschker et al. (1999) \\
\hline Rhine estuary (0-20 sal) & 1996-1998 & 4 to 9 & & & Abril et al. (2002) \\
\hline Rhine estuary (20-35 sal) & 1996-1998 & 5 to 20 & & & Abril et al. (2002) \\
\hline Rhine estuary (>0-35 sal) & & 3 to $9 / 20$ & -27.5 to -20 & & Middelburg \& Herman (2007) \\
\hline Ems estuary (0-30 saline) & July 1997 & 3 to 6 & & & Abril et al. (2002) \\
\hline Ems estuary (0-30 sal) & & $3-5.5$ & -24 to -22 & & Middelburg \& Herman (2007) \\
\hline Zeeschelde (B) & Apr-74 & & & & Mariotti et al. (1984) \\
\hline Western Scheldt & Apr-74 & & & & Mariotti et al. (1984) \\
\hline Western Scheldt & 0ct-78 & & & & Mariotti et al. (1985) \\
\hline Scheldt estuary (0-5 sal) & $1996+1998$ & 5 to 10 & & & Abril et al. (2002) \\
\hline Scheldt estuary (5-33 sal) & $1996+1998$ & 2.5 to 8 & & & Abril et al. (2002) \\
\hline
\end{tabular}


Table 16. Continued.

\begin{tabular}{|c|c|c|c|c|c|}
\hline $\begin{array}{l}\text { Sediment type } \\
\text { and location }\end{array}$ & $\begin{array}{l}\text { Sampling } \\
\text { period }\end{array}$ & $\begin{array}{l}\text { C organic } \\
(w t \%)\end{array}$ & $\begin{array}{l}\delta^{13} \mathrm{C} \text { organic } \\
(\% \text { PDB })\end{array}$ & $\begin{array}{l}{ }^{14} \mathrm{C} \text { organic } \\
(\mathrm{PMC})\end{array}$ & Reference \\
\hline Scheldt estuary (0-32 sal) & & 3 to 20 & -29.5 to -19 & & Middelburg \& Herman (2007) \\
\hline Scheldt estuary & & $\begin{array}{c}8.5 \text { to } 25 \text { (as } \\
\text { OrgM) }\end{array}$ & -30 to -24 & & Chen et al. (2005) \\
\hline Zeeschelde (B) & Dec-96 & $\begin{array}{c}3.7-24.6 \\
\mathrm{mg} / \mathrm{L}\end{array}$ & -27.6 to -26.5 & & Hellings et al. (1999) \\
\hline Zeeschelde (B) & Aug-96 & $\begin{array}{c}1.46-24.9 \\
\mathrm{mg} / \mathrm{L}\end{array}$ & -31.2 to -26.7 & & Hellings et al. (1999) \\
\hline Zeeschelde (B) & & & -31.1 to -23.7 & & De Brabandere et al. (2002) \\
\hline Zeeschelde (B) - "upper" & & & $-28.9 \pm 1.1$ & & $\begin{array}{l}\text { Middelburg \& Nieuwenhuize } \\
\text { (1998) }\end{array}$ \\
\hline Western Scheldt & $1985 ?$ & & $-26.6 \pm 2.2$ & & Laane et al. (1990) \\
\hline Western Scheldt - "lower" & & & $-20.1 \pm 1.7$ & & $\begin{array}{l}\text { Middelburg \& Nieuwenhuize } \\
\text { (1998) }\end{array}$ \\
\hline \multicolumn{6}{|l|}{ Geological sediments } \\
\hline $\begin{array}{l}\text { Drente F in eastern } \\
\text { Netherlands }\end{array}$ & & & $-25.1 \pm 1.1$ & & Hartog et al. (2005) \\
\hline $\begin{array}{c}\text { Breda F, Oosterhout F in } \\
\text { eastern Netherlands }\end{array}$ & & & $"$ & & Hartog et al. (2005) \\
\hline $\begin{array}{l}\text { Kreftenheije F, Twente F in } \\
\text { eastern Netherlands }\end{array}$ & & & $"$ & & Hartog et al. (2005) \\
\hline
\end{tabular}

F, Formation.

Table 17. Standard heavy mineral counts (in counts of 100) of the five HMAs distinguished by Baak (1936) in the bottom sands of the southern North Sea.

\begin{tabular}{|c|c|c|c|c|c|c|c|c|c|c|}
\hline HMA & Garnet & Hornblende & Epidote & Saussurite & Staurolite & Augite & Tourmaline & Metamorphic & Zircon & Rutile \\
\hline A group & 31 & 24 & 27 & 1 & 2 & 1 & 2 & 1 & 8 & 2 \\
\hline E group & 40 & 17 & 10 & 0 & 1 & 25 & 2 & 0 & 2 & 1 \\
\hline $\mathrm{T}$ group & 15 & 8 & 16 & 0 & 1 & 0 & 3 & 1 & 40 & 16 \\
\hline NH group & 15 & 10 & 9 & 15 & 2 & 40 & 2 & 3 & 0 & 0 \\
\hline $\mathrm{H}$ group & 30 & 14 & 26 & 15 & 4 & 3 & 3 & 3 & 3 & 1 \\
\hline
\end{tabular}

units that were transported from Scandinavian source areas (Schüttenhelm \& Laban, 2005).

- E group: with garnet and augite predominant and smaller amounts of hornblende and epidote. Hornblende is more frequent than epidote. The group is restricted to areas off the English northeast coast, south to the Norfolk Banks and the western Dogger Bank (Fig. 8). The E group, together with transitional associations, was interpreted by Baak to have a Scottish provenance on the basis of the association of peculiar garnet and augite. Admixed epidote and hornblende were thought to denote Scandinavian influxes and Baak suggested a Weichselian age. This group fits more or less with the distribution pattern of the various glacial units of Weichselian/Devensian age mapped during the Anglo-Dutch programme (Schüttenhelm \& Laban, 2005).
- Tertiary (T) group: with zircon, garnet and rutile predominating, less epidote and hornblende, and with a high opaque percentage too. This T group occurs off the Suffolk and Essex coast and locally off the Northumberland coast and elsewhere. According to Baak the T group indicates the reworking of mature Tertiary and older sediments. Schüttenhelm \& Laban (2005) agreed with this conclusion and attributed the absence of the T group in the Belgian sector (Tertiary is present at a depth of $30 \mathrm{~m}$ below surface; Schwartz, 1996) to the predominance of the younger H-type coastal sands.

- North Hinder (NH) group: with an augite, green hornblende and saussurite mineral assemblage, identical to Edelman's BLobith group (section 4.1). Here, the augite originates from the Rhine catchment. This group is found in the southernmost North Sea, away from the coast. This NH group must 


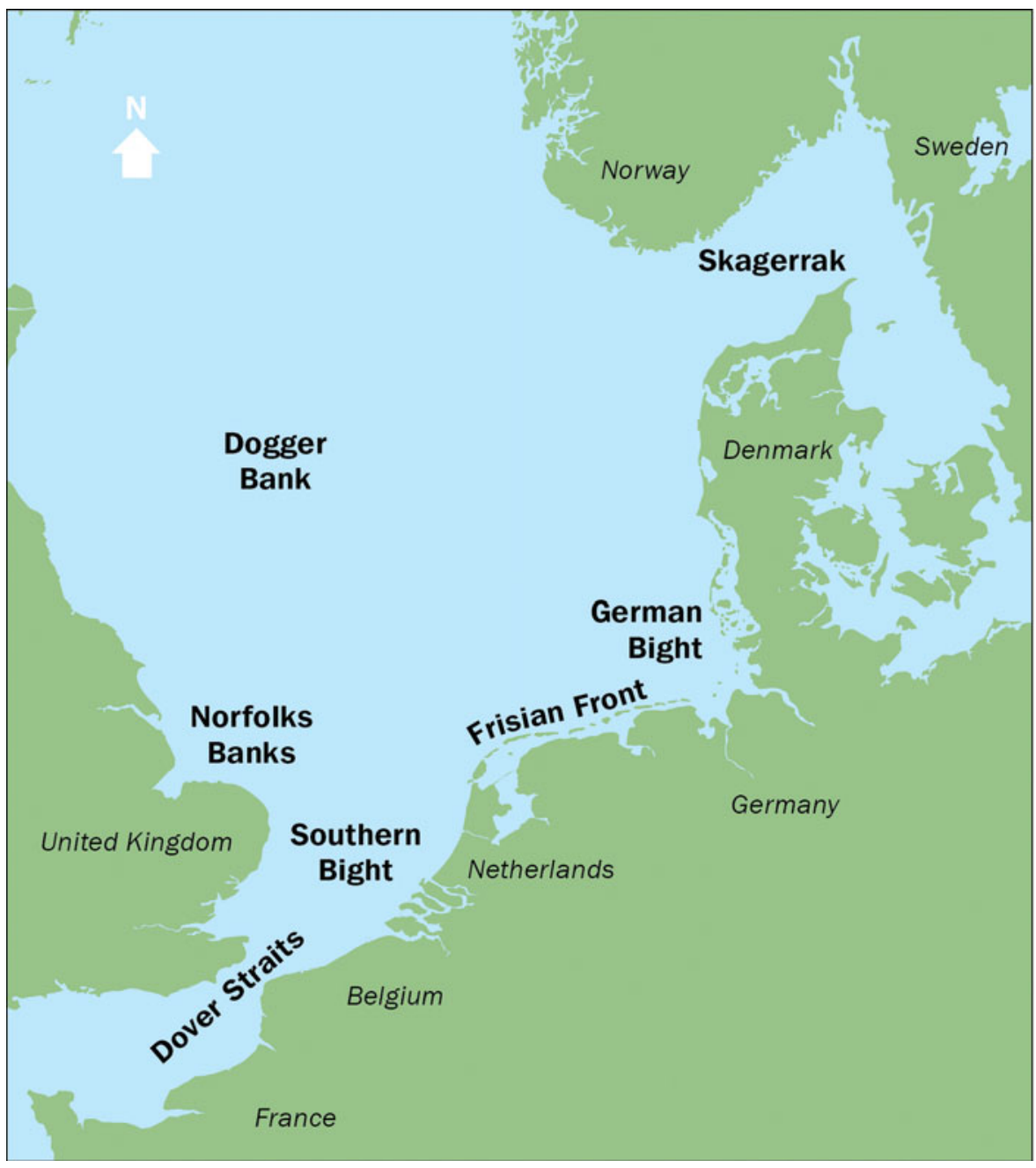

Fig. 7. Map of the southern North Sea with the locations of the geographical names referred to in this paper. be related to the offshore low-stand Rhine deposits of Late Pleistocene age rich in green augite. However, the distribution of $\mathrm{NH}$ group samples and transitional samples is much larger than the mapped occurrence of the Late Pleistocene fluvial Kreftenheye Formation off the southwestern Dutch coast (Schüttenhelm \& Laban, 2005). Recent work shows that in pre-Holocene times the ancestral Rhine must have extended far into the English Channel (e.g. Busschers et al., 2007; Toucanne et al., 2009). Large-scale, northward sand transport must have occurred during the initial Holocene transgression to get the geographical distribution of the $\mathrm{NH}$ group in line with the former river system (Van der Molen \& Van Dijck, 2000; Schüttenhelm \& Laban, 2005).

- H group: with a garnet, epidote, saussurite and hornblende HMA, already considered by Edelman (1933) to be a mixture of the HMAs he found along the Dutch coast. These reworked sands are omnipresent along the coasts of Dover Strait, western Netherlands and the Frisian islands. The saussurite percentages decrease to the north and east. From its distribution, Schüttenhelm \& Laban (2005) concluded that the various $\mathrm{H}$ group occurrences cannot be the result of one and the same mixing process. The samples in the English Channel result from alternating marine and fluvial sedimentation and related reworking. The highly dynamic Dover Strait area accounts for the highly mixed sands sampled there (Van der Molen \& Van Dijck, 2000). Over time, tidal amplitudes and currents continued to increase but the orientation of currents and the resulting sand transport in the eastern part of the Southern Bight gradually changed from perpendicular to parallel with the shore, which accounts for the presence of the $\mathrm{H}$ group sediments all along the Belgian and Dutch coast. The initial inlet coast type certainly aided the mixing process and brought $\mathrm{H}$ group sediments within the present coastline of the Netherlands too (Beets \& Van der Spek, 2000). According to Baak (1936), but based on two samples only, the mixed provenance $\mathrm{H}$ group extends to the East Frisian islands. However, Ludwig \& Figge (1979) found only A group assemblages (cf. section 4.1) on the shoreface and suggested that ongoing reworking of glacial deposits (Hoselmann \& Streif, 2004) is reinforcing the existing A group and diluting any $\mathrm{H}$ group influxes brought in by the prevailing westerly longshore drift. 


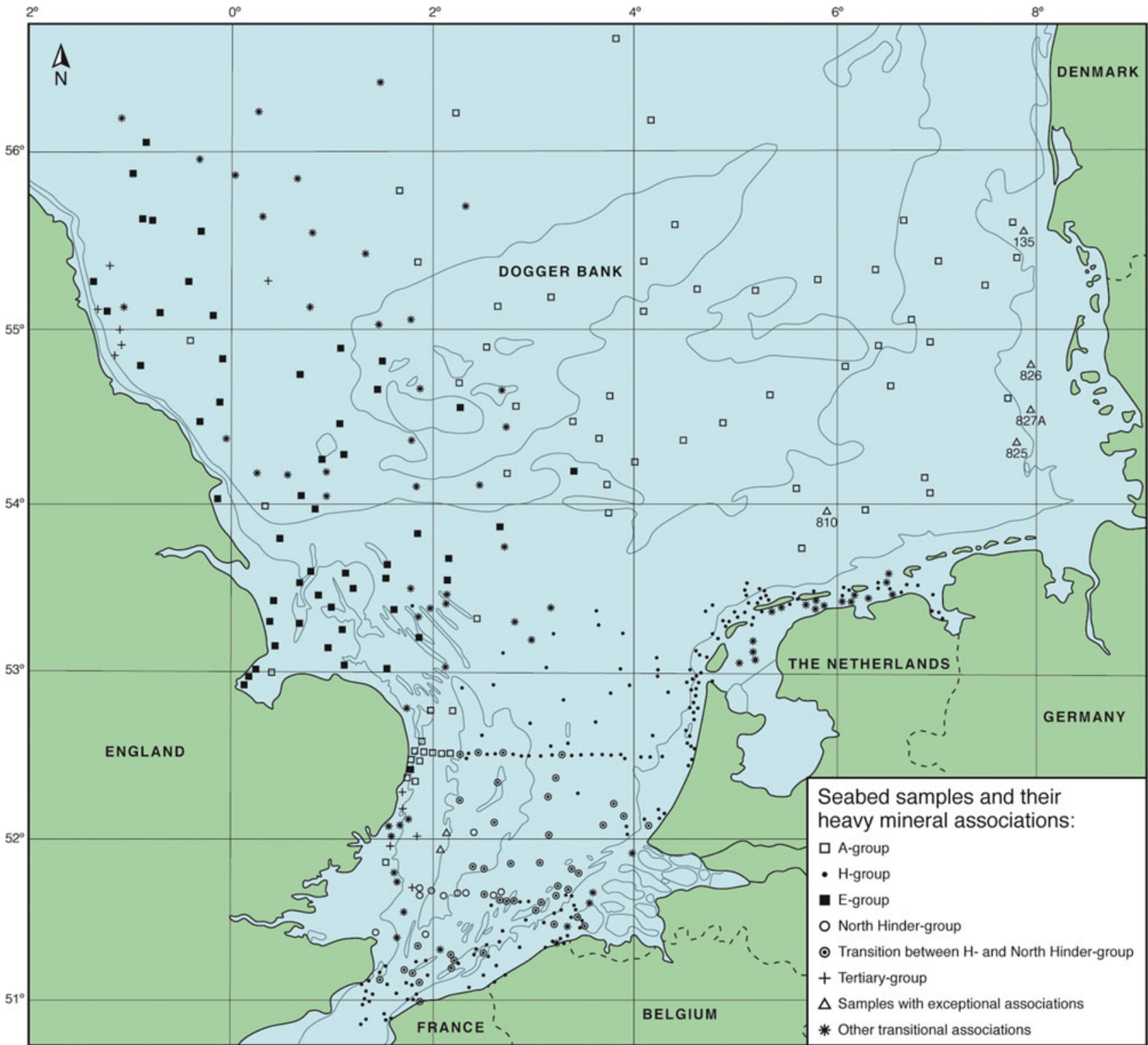

Fig. 8. Distribution of the heavy mineral assemblages across the southern North Sea (redrawn from Schüttenhelm \& Laban, 2005).

5.1.2 The Wadden Sea and the Scheldt estuary. The heavy minerals of the sands in the Wadden Sea and the Scheldt estuary were studied by Baak (1936) and in more detail by Crommelin (1940). They predominantly consist of garnet, epidote, hornblende and zircon, with minor quantities of saussurite, staurolite, tourmaline and other minerals (mix of the A group of Edelman with slight admixtures from Baak's $H$ group). The fine sands along the mainland coast are comparatively rich in opaque minerals, epidote and zircon; the coarser sands in the north contain more garnet and a little more hornblende. The same compositional dependency on the grain sizes was observed for the Scheldt estuary (Van Straaten, 1954) but, as discussed by Van Straaten (1954), the character of these relationships is nevertheless only of local significance. The composition of the Wadden Sea sands is very similar to that of the adjacent parts of the North Sea floor (cf. Baak, 1936). The material consists of locally reworked Pleistocene material selected, transported and imported into the Wadden Sea by marine processes (e.g. Baak, 1936; Crommelin, 1940; Winkelmolen \& Veenstra, 1974, 1980; Mulder, 2000; Hoselmann \& Streif, 2004). The same conclusion was reached with regard to the sands in the estuaries of the provinces of North and South Holland and Zeeland (Baak, 1936; van Veen, 1936; Crommelin, 1951). A small amount of sand and a larger amount of fines are imported with the currents flowing from the south parallel to the coast along the Dutch part of the Wadden (Schüttenhelm \& Laban, 2005; 0ost et al., 2012). Crommelin's and Baak's conclusions for the Wadden Sea were confirmed in a recent study (0ost et al., 2012) on the development of the barrier islands of the Wadden Sea. All the above-mentioned studies conclude that rivers have never brought substantial amounts of sediments into the Wadden Sea. Crommelin (1943) also studied the mineral composition of the 


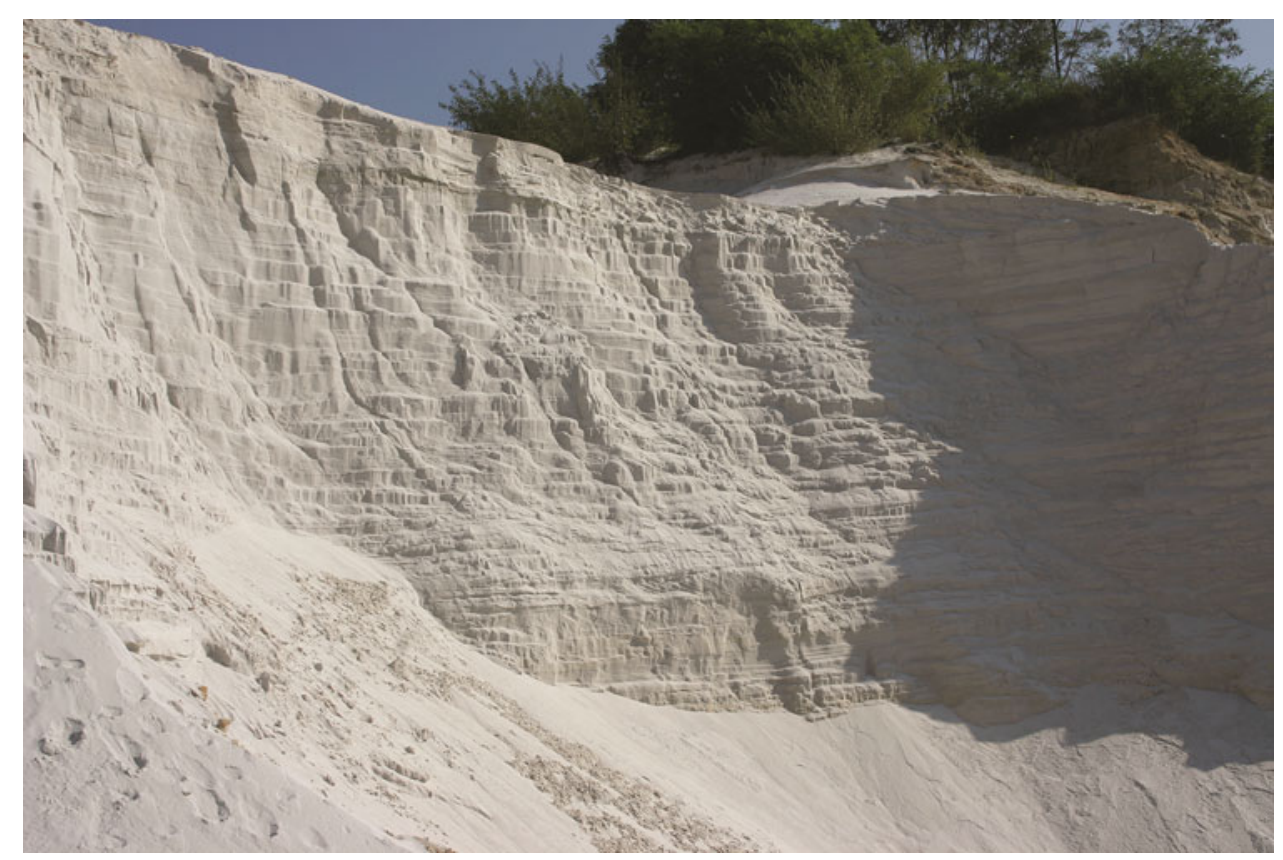

Fig. 9. So-called 'silver sand' in the Beaujean quarry in southern Limburg.

silt fraction and came to the same conclusion: like the sand fractions, most of the silt fractions originate from the North Sea. Direct fluvial supply can have been of only subordinate importance. This applies both to the Wadden Sea silts and to those of the Scheldt estuary.

5.1.3 Beach and dune sands. Edelman (1933) and Baak (1936) studied the HMAs present in the beach and dune sands along the Dutch west coast. Edelman's data are given in Table 18. A comparison with Table 17 shows that these sands belong to Baak's H group. The average mineral contents of the 200-250 $\mu \mathrm{m}$ fraction given by Eisma (1968) differ considerably from those of the $>30 \mu \mathrm{m}$ fraction given by Edelman (Table 18). The Dutch coastal sands, i.e. dune, beach and shoreface sands, vary greatly in grain size and composition, but two main types of sand are distinguished:

1. High quartz (often coloured) contents (>95\%), with garnet as the dominant heavy mineral (Table 18). This type is found chiefly north of Bergen (beach pole 37) on the North Holland coast (Edelman, 1933; Baak, 1936). These sands on the beaches and in the dunes are low in $\mathrm{Ca}$ and Mg (Eisma, 1968).

2. Lower quartz (less coloured) contents $(<90 \%)$, with saussurite and hornblende dominating its HMAs (Table 18). These sands on the beaches and in the dunes have high $\mathrm{Ca}$ and $\mathrm{Mg}$ contents between $\mathrm{km}$ poles 44 and 92, increasing gradually between $\mathrm{km}$ poles 34 and 44 (Eisma, 1968).

According to Edelman's data the boundary between the two types is sharp: mixing occurs over a distance less than $1 \mathrm{~km}$. The differences in HMAs (Table 18) suggest a difference in origin.
Edelman (1933) found HMAs of the following sources in the coastal sands:

- River sands from the Rhine, Meuse and perhaps Scheldt. However, the recent supply of river sands of the Rhine, Meuse and Scheldt is very small (Van Veen, 1936; Terwindt et al., 1963) but conditions may have been different during the older, Holocene periods (Van Straaten, 1963).

- River sands from the Eridanos system.

- Sands present in the Saalian glaciation.

- Reworked Tertiary sands from the mouth of the Scheldt (which are easily recognisable from the accompanying Tertiary Bryozoa).

Eisma (1968) used the same preparation and petrological method as Edelman (1933) and Baak (1936), except that he studied four grain size classes between $100 \mu \mathrm{m}$ and $315 \mu \mathrm{m}$ separately. Only data for the 200-250 $\mu \mathrm{m}$ fraction are given in Eisma (1968). Eisma found that north of the coastal village of Bergen (beach pole 37) both the beach sands and the fine fractions of the dune sands contain more heavy minerals than south of Bergen (km pole 37; Table 19). An identical geographical separation was found for the feldspar, Al, Ca carbonate, $\mathrm{Mg}$ carbonate and Fe contents, with the Al proportional to the feldspar content in these sands (Eisma, 1968). Table 19 also shows that the heavy mineral contents are not equally distributed over the separated fractions. The heavy mineral content of the finest fraction $(100-160 \mu \mathrm{m})$ is 10 to 100 times more than that of the 200-250 $\mu \mathrm{m}$ fraction. Eisma reported that in the $200-250 \mu \mathrm{m}$ and $250-315 \mu \mathrm{m}$ fractions near beach pole 37 there is a sharp increase in the garnet and an even sharper increase in tourmaline, but a decrease in saussurite contents 
Table 18. Average heavy mineral contents (in counts of 100) of the beach and dune sands deposited along the Dutch coast from Den Helder to Hoek van Holland. Data for the 200-250 $\mu \mathrm{m}$ fraction from Eisma (1968) and for the $>30 \mu \mathrm{m}$ fraction from Edelman (1933).

\begin{tabular}{|c|c|c|c|c|c|c|c|c|c|c|}
\hline Type & $\begin{array}{l}\text { Kilometres from } \\
\text { Den Helder }\end{array}$ & $\begin{array}{l}\text { Grain } \\
\text { size }(\mu \mathrm{m})\end{array}$ & Garnet & Hornblende & Epidote & Saussurite & Staurolite & Augite & Tourmaline & Kyanite \\
\hline Beach & 2 to 36 & $200-250$ & 33.5 & 6.6 & 17.4 & 20.8 & 4.6 & 0.3 & 9.2 & 3.9 \\
\hline Dune & Den Helder - Bergen & $200-250$ & 26.0 & 7.2 & 21.7 & 27.6 & 3.7 & 0.2 & 8.5 & 2.4 \\
\hline Beach & & $>30$ & 37.2 & 6.4 & 17.7 & 18.1 & 4.7 & 1.8 & 7.7 & 1.3 \\
\hline Beach & 37 to 53 & $200-250$ & 7.3 & 18.6 & 14.9 & 49.7 & 1.3 & 1.5 & 2.0 & 1.7 \\
\hline Dune & Bergen - Ijmuiden & $200-250$ & 7.1 & 15.1 & 13.3 & 55.9 & 1.1 & 1.8 & 2.0 & 2.2 \\
\hline Beach & & $>30$ & 21.8 & 15.4 & 17.1 & 28.5 & 3.4 & 4.2 & 3.8 & 0.8 \\
\hline Beach & $53-91$ & $200-250$ & 2.7 & 18.5 & 14.9 & 49.7 & 1.3 & 1.5 & 2.0 & 1.7 \\
\hline Dune & IJmuiden-Scheveningen & $200-250$ & 3.1 & 17.8 & 17.5 & 49.6 & 1.0 & 3.1 & 1.4 & 1.0 \\
\hline Beach & & $>30$ & 22.5 & 17.5 & 24.3 & 18.1 & 2.9 & 1.6 & 3.3 & 1.3 \\
\hline \multirow[t]{4}{*}{ Beach } & $92-118$ & $>30$ & 25.4 & 12.0 & 21.3 & 25.0 & 2.8 & 5.7 & 3.0 & 0.7 \\
\hline & Scheveningen - & & & & & & & & & \\
\hline & Hoek v Holland & & & & & & & & & \\
\hline & Oost-Voorne & $>30$ & 32.4 & 10.3 & 20.5 & 18.6 & 2.9 & 2.2 & 4.5 & 0.6 \\
\hline
\end{tabular}

Table 19. Heavy mineral content (in \%) of individual size fractions of beach and dune sands collected between Scheveningen (km pole 91) and Den Helder (km pole 2) (derived from Eisma (1968)).

\begin{tabular}{|c|c|c|c|c|c|}
\hline Type & Kilometres from Den Helder & $100-160 \mu \mathrm{m}$ & $160-200 \mu \mathrm{m}$ & $200-250 \mu \mathrm{m}$ & $250-315 \mu \mathrm{m}$ \\
\hline Beach & 2 to 36 & 37 & 9 & 2 & 0.26 \\
\hline Dunes & & 18 & & 0.09 & \\
\hline Beach & 26 to 36 & 41 & 11 & 2 & 0.32 \\
\hline Dunes & & 20 & & 0.11 & \\
\hline Beach & 37 to 53 & 7 & 0.6 & 0.16 & 0.07 \\
\hline Dunes & & 5 & & 0.07 & \\
\hline Beach & 53 to 91 & 2 & 0.3 & 0.16 & 0.09 \\
\hline Dunes & & 2 & & 0.09 & \\
\hline
\end{tabular}

(higher to the north) (Table 19). However, this change is more gradual in the $160-200 \mu \mathrm{m}$ fraction while in the 100-160 $\mu \mathrm{m}$ fraction no change is apparent.

During the Holocene, the area north of Bergen remained land or was a shallow tidal flat separated by the so-called Bergen tidal inlet from the coastal sands further south. The Bergen tidal inlet was the largest tidal inlet in the Dutch coast and was closed around 3300 BP (Beets \& Van der Spek, 2000). This northwestern headland with its core of glacial sands was gradually eroded, providing A group material. The transition in the HMAs along the Dutch coastal sands coincides with the Bergen tidal inlet, indicating that this inlet acted as an effective trap for northbound sands as long as it existed.

Eisma (1968) attributed the co-occurrence of the two completely different HMAs at Bergen partly to the geologically recent, Holocene conditions along the coast and partly to the general history of the sands. His study confirmed the mixed nature of Baak's $H$ group and the mixed provenance of the coastal sands since Saalian times. His interpretation was that the sands north of Bergen consist mainly of reworked glacial deposits from Saalian age and Rhine-Meuse sands having the $S$ association (section 4.1). North of Bergen no carbonate is present in the beach sands and therefore their $\mathrm{pH}$ would have been low, which may have enhanced silicate weathering. This more severe weathering resulted in loss of some hornblende and probably also of augite, but its effect on the composition of the HMA was small (Eisma, 1968). The HMAs south of Bergen were interpreted by Eisma as reworked Rhine sands of the $\mathrm{S}$ association with an admixture of Late Pleistocene and Holocene Rhine sands of the AS association (section 4.1). The mixing occurred during the Eemian (by the sea), Weichselian (by the wind) and the Holocene (during coastal erosion and the formation of inlets). Erosion did not reach great depths except locally in the tidal inlets, which explains the virtual absence of an admixture of sands of the Eridanos system, usually present at a depth of some 25-60 m or less below the Saalian deposits.

5.1.4 Heavy mineral contents. The amount of heavy minerals has generally not been determined. Normally, it is less than $1-2 \%$ in the sand fraction of Dutch sediments (Druif, 1927; Van 
Andel, 1950; Wartel, 1977). Based on non-invasive radiometric seafloor mapping, De Meijer (1998) indicates that it may amount to up to a few per cent at the seafloor immediately north of Terschelling and Ameland. However, thin layers of beach sand have been observed that have several tens of per cent of heavy minerals (Crommelin \& Slotboom, 1945; Schuiling et al., 1985). These layers are referred to as garnet sand layers because garnet is the dominant heavy mineral and is responsible for the purple reddish or olive-green brownish colour. They are found along the entire Dutch coast from Zeeland to Ameland (Van der Sleen, 1912; Crommelin \& Slotboom, 1945; De Meijer et al., 1990). Their origin is explained as storm erosion of dunes with a collapse on the beach and subsequent washing away of light minerals, leaving the heavy minerals. The sharp lower boundary of such layers fits this explanation. Crommelin \& Slotboom (1945) found that such a layer consisted of $57 \%$ garnet and $18 \%$ opaque $\mathrm{Fe}$ oxides. De Meijer et al. (1990) found up to 70\% heavy minerals in a series of 16 samples but did not elucidate what kinds of layers were sampled at beaches along the coast.

5.1.5 Quaternary and Neogene marine formations. Investigations of Young Tertiary deposits in the Netherlands, SchleswigHolstein and Denmark have shown an evident connection between depositional environment and heavy mineral associations of the sediments for sediments originating from Scandinavia. It seems to be a fundamental rule that such marine sediments are characterised by the unstable heavy minerals amphibole and epidote, whereas non-marine sediments are generally characterised by more stable heavy minerals and typically do not contain amphibole (Edelman, 1938; Weyl, 1950, 1952a,b, 1953; Larsen \& Dinesen, 1959; Larsen \& Friis, 1973). Table 20 illustrates that all the Dutch marine geological formations are characterised by unstable HMAs.

5.1.6 Weathering and silica sands. Characteristic examples of bright white sands consisting almost exclusively of quartz (called 'silver sand' in the Netherlands) occur in the marine Breda Formation (Heksenberg Member; De Mulder et al., 2003). They are well-sorted, fine-grained, with well-rounded grains and are considered to be beach or coastal sands (De Mulder et al., 2003). The quartz content of this silica sand is at least $98 \%$ and the heavy mineral content is exceptionally low (0.003\%; Van der Meulen et al., 2009; Van Loon, 2009). The silica sand is overlain by a lignite unit, although in places this lignite has been entirely eroded. Van Loon (2009) hypothesised that the extreme weathering was most probably caused by infiltrating soil water rich in humic acids and by prolonged surficial exposure to weathering in a humid tropical or subtropical climate. Here, Van Loon (2009) also states that neither of these two options is completely satisfactory in itself to explain all weathering features of the silica sands: why is the lower boundary sometimes so sharp and where is the leached-out material? As well as containing very low proportions of heavy minerals, the sands also contain a limited variety of heavy minerals as a result of dissolution of the less stable minerals. The silica sand contains only three heavy minerals that are available for a weathering analysis: garnet, staurolite and tourmaline (Van Loon \& Mange, 2007). Tourmaline can be surprisingly strongly weathered in this silica sand, probably because of its specific chemistry (Van Loon \& Mange, 2007). Staurolite, when present, appears to be most suitable for assessing the intensity of weathering in the extremely weathered silica sand. One other surprising outcome is the co-occurrence of fresh and strongly weathered grains of heavy minerals such as garnet and staurolite, which are considered to have low resistance to weathering. To explain this, the term 'differential weathering' was introduced and this should have taken place at a small spatial scale (Van Loon, 2009). The fragile weathered form of the heavily corroded grains indicates that they must have been produced in situ because they would have been destroyed by the vigorous action of waves and currents in their depositional environment.

\subsection{Clay minerals}

With the exception of the studies by Zuther et al. (2000), Pache et al. (2008), Zeelmaekers (2011), Koenen \& Griffioen (2013) and Adriaens (2014), who state that their results are quantitative or at least semi-quantitative, all the other studies cited below qualify their data at best as semi-quantitative. To understand the distribution of the clay assemblages in the North Sea, it is now generally agreed that clays in seawater are transported in flocs with a size of about $40 \mu \mathrm{m}$ (e.g. Zeelmaekers, 2011).

5.2.1 Coastal sediments. The first systematic study of the clay mineralogy in the Netherlands was initiated in 1935 to solve the origin of sedimentary mud in the land reclamation of the Wadden Sea. As already discussed in the paragraph on the heavy minerals, not only the fine fraction was studied but also the silt and sand fractions (Crommelin, 1940, 1943). As the 'Wadden' mud may be composed of clastic material originating from the North Sea or the rivers Ems, Weser, Elbe and Rhine, various samples of these possible sources were investigated, together with mud from old clay banks and mussel banks in the Wadden Sea. Three fractions were studied after the samples had been treated with $\mathrm{HCl}$ and $\mathrm{H}_{2} \mathrm{O}_{2}$ to remove the organic matter, carbonate and sulphides (Favejee, 1951).

A compilation of the results is given in Table 21, in which the fluvial clays studied are also included. The figures show that the size fraction has a great influence on the mineralogy. The bulk of the clay fraction is made up of quartz and illite, with the first decreasing and the latter increasing in frequency with diminishing grain size (Table 21). The remainder is composed of kaolinite, montmorillonite, illite + muscovite and feldspars.

No significant distinction in mineral composition can be made between the muds from the Wadden Sea, from the Eastern and Western Scheldt estuaries, the North Sea floor and the 
Table 20. Heavy mineral assemblages and glauconite presence of the Quaternary and Neogene marine formations. Data are from Westerhoff (2009), Doppert et al. (1975) and Baak (1936). No systematic data could be found on the quantities of feldspars in the marine geological formations.

\begin{tabular}{|c|c|}
\hline Formation & Heavy mineral assemblages \\
\hline \multicolumn{2}{|l|}{ Holocene } \\
\hline Naaldwijk & No information \\
\hline \multicolumn{2}{|l|}{ Pleistocene } \\
\hline Eem & $\begin{array}{l}\text { Unstable HMA: garnet, epidote, saussurite and hornblende; minor amounts of augite, tourmaline, staurolite and metamorphic } \\
\text { minerals }\end{array}$ \\
\hline Maassluis & Unstable HMA: garnet, epidote, saussurite/alterite and hornblende; some traces of glauconite \\
\hline \multicolumn{2}{|l|}{ Neogene } \\
\hline Oosterhout & $\begin{array}{l}\text { Unstable HMA: hornblende often the dominant mineral, epidote and traces of metamorphic minerals, tourmaline and garnet; } \\
\text { often glauconite-bearing }\end{array}$ \\
\hline Breda & $\begin{array}{l}\text { Unstable HMA: hornblende-rich, epidote, minor amounts of metamorphic minerals and traces of garnet and tourmaline; often } \\
\text { extremely glauconite-rich }\end{array}$ \\
\hline
\end{tabular}

suspended material in the tidal inlets (Favejee, 1951): the composition seems to be highly uniform along the whole Dutch coast. However, there is a noticeable difference between the marine muds and fluvial clays. The latter have a low content of montmorillonite and strongly varying percentages of kaolinite and quartz (Table 21; Favejee, 1951). The outcomes of the clay mineralogy (Favejee, 1951) and heavy mineral studies on the silt and sand fractions (Crommelin, 1940, 1943) in the Wadden Sea and the estuaries in Zeeland are similar: the sediments in the Wadden Sea and the estuaries in Zeeland are predominantly marine in origin (see also Van Straaten, 1954).

No further systematic studies have been performed, but Breeuwsma (1985) summarised the results of a number of small projects in which the clay minerals were determined and compared the characteristics of marine and fluvial clays. The results for the river and the marine clays are given in Table 6 . The results show that the $<2 \mu \mathrm{m}$ fraction of Dutch soil clays comprises approximately $85 \%$ of clay minerals and the rest is made up of quartz, feldspars and oxides of $\mathrm{Si}, \mathrm{Al}$ and Fe. Breeuwsma analysed samples from West Friesland and Zeeland but gives no semi-quantitative results for these areas in his paper. In the rest of this section we assume, in accordance with the findings of Favejee (1951) and as discussed by Breeuwsma (1985), that the West Friesland/Zeeland and Friesland/Groningen clays have the same clay mineralogy. As pointed out in section 4.2, the major differences between recent marine and fluvial clays in the Netherlands are the differences in the vermiculite and smectite contents (Table 6). Analyses of the smectite-illite minerals showed that the Fe content in marine clays is much higher than in the fluvial clays and that because of the higher vermiculite content of the fluvial clays, the $\mathrm{K}$ fixation and CEC of the fluvial clays are higher (Breeuwsma, 1985).

Transport studies of marine sediments along the Dutch coast (Terwindt, 1977; De Groot, 1963; Eisma, 1981) all show that the amount of mud originating from the English Channel exceeds the discharge of fine material by the Rhine and Meuse. This conclusion is in agreement with the conclusions of Salomons (1975) and Salomons et al. (1975), who on the basis of the isotopic composition of both the carbonate and clay minerals estimated that no more than $20 \%$ of the mud in the Wadden Sea originated from the Rhine-Meuse delta. Based on the above literature, the difference in recent marine and fluvial clays (Rhine-Meuse delta) was attributed by Breeuwsma (1985) to a large southern North Sea component (erosion of English cliffs) in the marine clays.

In a thematically comparable study in which more advanced XRD analysis techniques were used, Zeelmaekers (2011) compared the results of the Scheldt estuary with bottom samples from mudflats along the Belgian coastal zone and recent sediments from the Paulina salt marsh located about $20 \mathrm{~km}$ from the mouth of the Scheldt estuary (Tables 6 and 22). The age of the latter sediments was estimated to be between 50 and 100 years. For the marine part of the Scheldt estuary (including the Paulina salt marsh) the clay mineralogy was found to be identical with that of the mudflats along the Belgian coastal zone. Further upstream, starting $40 \mathrm{~km}$ from the Scheldt mouth, the detailed qualitative composition was still the same, but a subtle increase in the smectite content was found. Zeelmaekers draws the logical conclusion that the suspended particulate matter (SPM) in the mud plate area and the Western Scheldt area forms one well-mixed continuum in which the marine SPM is transported up the estuary. He further concludes that there are in fact two different types of SPM in the Scheldt estuary: marine-dominated SPM in the saline Western Scheldt and riverine-dominated SPM in the more upstream brackish Middle and fresh Upper Estuaries. This agrees with previous findings that the SPM in the marine part of the Scheldt estuary has a very high marine character (>80\%; Van Alphen, 1990; Verlaan et al., 1998; Baeye et al., 2011).

5.2.2 North Sea seabed sediments. The clay mineralogy analysis of the surface sediments of the North Sea shows a high 
Table 21. Mineralogical composition (in wt\%) of the fractions $<0.5,0.5-2$ and 2-10 $\mu \mathrm{m}$ of mud deposited along the Dutch and German coast (derived from Favejee (1951)).

\begin{tabular}{|c|c|c|c|c|c|c|c|c|c|c|c|c|c|}
\hline \multirow[b]{2}{*}{ Sample } & \multicolumn{4}{|c|}{ Fraction $<0.5 \mu \mathrm{m}$} & \multicolumn{4}{|c|}{ Fraction $0.5-2 \mu \mathrm{m}$} & \multicolumn{5}{|c|}{ Fraction $2-10 \mu \mathrm{m}$} \\
\hline & Illite & Kaolinite & Montmorillonite & Quartz & $\begin{array}{l}\text { Illite }+ \\
\text { muscovite }\end{array}$ & Kaolinite & Montmorillonite & Quartz & $\begin{array}{l}\text { Illite }+ \\
\text { muscovite }\end{array}$ & Kaolinite & Montmorillonite & Quartz & Feldspar \\
\hline \multicolumn{14}{|c|}{ Mud and sediments from the Wadden Sea } \\
\hline I & c. 80 & $5-10$ & c. 10 & c. 4 & $50-60$ & $5-10$ & $5-10$ & c. 30 & & & & & \\
\hline IIa & $80-90$ & $5-10$ & c. 5 & c. 4 & & & & & & & & & \\
\hline IIb & $80-90$ & c. 5 & $5-10$ & $2-4$ & $50-60$ & c. 10 & $5-10$ & $25-30$ & c. 30 & c. 5 & c. 5 & $50-60$ & c. 5 \\
\hline IIc & $80-90$ & c. 5 & $3-5$ & c. 6 & c. 60 & c. 5 & c. 5 & c. 30 & & & & & \\
\hline III & c. 80 & $5-10$ & $5-10$ & c. 4 & c. 60 & $5-10$ & c. 5 & c. 25 & c. 60 & $5-10$ & c. 5 & c. 50 & $5-10$ \\
\hline \multicolumn{14}{|c|}{ Suspended matter from the Wadden Sea } \\
\hline IV & c. 80 & $5-10$ & $5-10$ & c. 6 & c. 60 & $5-10$ & c. 5 & c. 30 & & & & & \\
\hline $\mathrm{V}$ & $80-90$ & $5-10$ & c. 5 & $4-6$ & c. 60 & $5-10$ & c. 5 & c. 30 & $20-30$ & c. 5 & c. 5 & c. 60 & $5-10$ \\
\hline \multicolumn{14}{|c|}{ Mud from bottom sediments in the North Sea and marshes in Zeeland } \\
\hline VI & $80-90$ & $5-10$ & $3-5$ & c. 2 & c. 50 & c. 15 & $5-10$ & c. 30 & c. 20 & c. 10 & c. 5 & c. 50 & c. 10 \\
\hline VII & $80-90$ & c. 5 & $5-10$ & $2-4$ & c. 60 & c. 10 & $5-10$ & c. 25 & & & & & \\
\hline \multicolumn{14}{|c|}{ Fluvial clays } \\
\hline VIIIa & $>95$ & - & $<3$ & $<1$ & $>90$ & $<1$ & $<3$ & $>50$ & $>50$ & $<1$ & $<3$ & $>90$ & $<1$ \\
\hline VIIIb & c. 90 & $3-5$ & $<3$ & c. 5 & c. 60 & c. 5 & c. 5 & $30-40$ & c. 30 & $3-5$ & $<3$ & c. 60 & c. 5 \\
\hline VIIIc & $70-80$ & $5-10$ & $<3$ & c. 15 & & & & & & & & & \\
\hline VIId & $80-90$ & c. 10 & $<3$ & c. 5 & $40-50$ & c. 10 & c. 5 & c. 40 & & & & & \\
\hline
\end{tabular}

I Recent Wadden mud of land reclamations along the coast of Groningen province.

II Mud from bottom sediments in the Wadden Sea: a, mussel banks; b, mud with shell fragments; c, mussel pellets. III Old clay banks in the Wadden Sea.

IV Mud from suspended matter taken during ebb tide, south of Schiermonnikoog.

$\checkmark$ Mud from suspended matter sampled in the tidal inlets of the Wadden Sea.

VI Mud from bottom sediments of the North Sea, south and southeast of the Dogger Bank and the German Bight.

VIII Mud in suspended matter from the rivers: a, Ems; b, Weser; c, Elbe; d, Rhine. 
Table 22. Clay mineralogy (as ranges in wt\%) from mudflats on Belgian Coastal Shelf, Scheldt river and estuary, and marine recent and older deposits from the North Sea and the Netherlands (derived from Zeelmaekers (2011) and Adriaens (2014)).

\begin{tabular}{lccccc}
\hline Type of sediment & Samples & Total illite & Total smectite & Kaolinite & Chlorite \\
\hline Belgian coastal zone & 25 & $36-57$ & $22-49$ & $12-15$ & $2-9$ \\
On mudflat & 13 & $26-51$ & $29-59$ & $12-15$ & $3-8$ \\
Outside mudflat & 4 & $33-43$ & $39-53$ & $11-12$ & $2-6$ \\
Above mudflat & & & & $12-15$ & $3-5$ \\
Scheldt river and estuary & 6 & $40-49$ & $33-42$ & $11-18$ & $2-7$ \\
Estuary to Bath & 17 & $33-51$ & $29-50$ & $12-13$ & $2-5$ \\
Upstream of Bath & 5 & $38-44$ & $39-45$ & $8-13$ & $1-9$ \\
Rupel tributary & 5 & $38-56$ & $26-47$ & $13-14$ & 5 \\
Secondary tributaries & 3 & $42-49$ & $33-39$ & & $10-22$ \\
Paulina marsh & & & & $10-14$ & $1-4$ \\
Marine recent and older sediments & 9 & $46-60$ & $24-41$ & $39-43$ & $3-11$
\end{tabular}

heterogeneity in the distribution of the individual clay mineral groups of smectite, illite, kaolinite and chlorite. Using 500 samples, Irion \& Zöllmer (1999) studied the clay mineral composition of the $<2 \mu \mathrm{m}$ fraction of the generally coarse surface sediments of the North Sea and constructed maps of the distribution of the clay minerals illite, chlorite, smectite and kaolinite in these surface sediments (Fig. 10). The smectite content varies between 5 and $53 \%$ (Table 6). Almost half of the samples belong to the $20-30 \%$ smectite category and are present in the central area, in large parts of the southern North Sea and in the Norwegian Channel as well. Smectite contents of $30-40 \%$ are distributed in a narrow zone along the Dutch coast and along the coast of East Anglia, where they co-occur with smectite contents of more than $40 \%$. The illite distribution varies between $34 \%$ and $67 \%$ (Table 6 ). The highest fractions are found in the very north and in two areas north and south of the mouth of the river Rhine. Kaolinite ranges from $2 \%$ to $23 \%$. Low contents are found in the northwestern part and along the southern and eastern North Sea coast (including the Dutch coast). Along the Dutch coast, the chlorite percentages vary between $10 \%$ and $15 \%$.

It is assumed that the distribution pattern of the different clay mineral associations indicates the origins and pathways of the suspended matter in the North Sea. As in the case of the heavy mineral associations in the surface sediments (Baak, 1936; Schüttenhelm \& Laban, 2005), the heterogeneity is attributed to the various sedimentological processes which have occurred from the Middle Pleistocene to the present day. During cold Pleistocene periods, large ice masses carried illite- and chlorite-rich tillites from the north into the North Sea Basin. This material originated from the Fennoscandian Shield and was deposited in the entire basin during the Elster and Saale glaciations, whereas during the Weichsel only the northern part was covered by the ice sheets (Streif, 1990), therefore the fractions of illite and chlorite are higher in the north. On the basis of the literature and their own data, Irion \& Zöllmer (1999) concluded that it seems unlikely that the North Atlantic is an effective source of sediments for the North Sea. The composition of the mud in the Skagerrak and the Norwegian Channel differs greatly from that of mud in the other regions of the northern North Sea (lower chlorite and higher smectite and kaolinite contents). On the west coast of the North Sea (East Anglia), the most striking phenomenon is the relatively high kaolinite content of the sediments. The kaolinite originates mainly from Weichselian tillites formed from Pleistocene sediments and Tertiary soils. On the East Anglia coast there is intensive cliff erosion (McCave, 1987), which delivers kaolinite-rich material directly to the sea. The distribution of kaolinite-rich sediments corresponds with the calculations and remote sensing data of McManus \& Prandle (1997). The high smectite values along the Belgian and Dutch coasts are explained as the erosion products of the smectite-rich Cretaceous formations of the Dover Strait. About 50\% of these Dover Strait sediments are transported by longshore drift along the Belgian-Dutch coast, some reaching the German Lower Saxony coast (Salomons, 1975; Salomons et al., 1975; Van Alphen, 1990; McManus \& Prandle, 1997; Brockamp \& Clauer, 2012).

Irion and Zöllmer (1999) attribute the large amounts of smectites in the German Bight to the Elsterian glaciation. This material was later mixed with illite- and chlorite-rich sediments from the north but nonetheless remained rich in smectite. Using mass-balance calculations, Hoselmann \& Streif (2004) calculated that $90 \%$ of the sediment volume along the Lower Saxony 


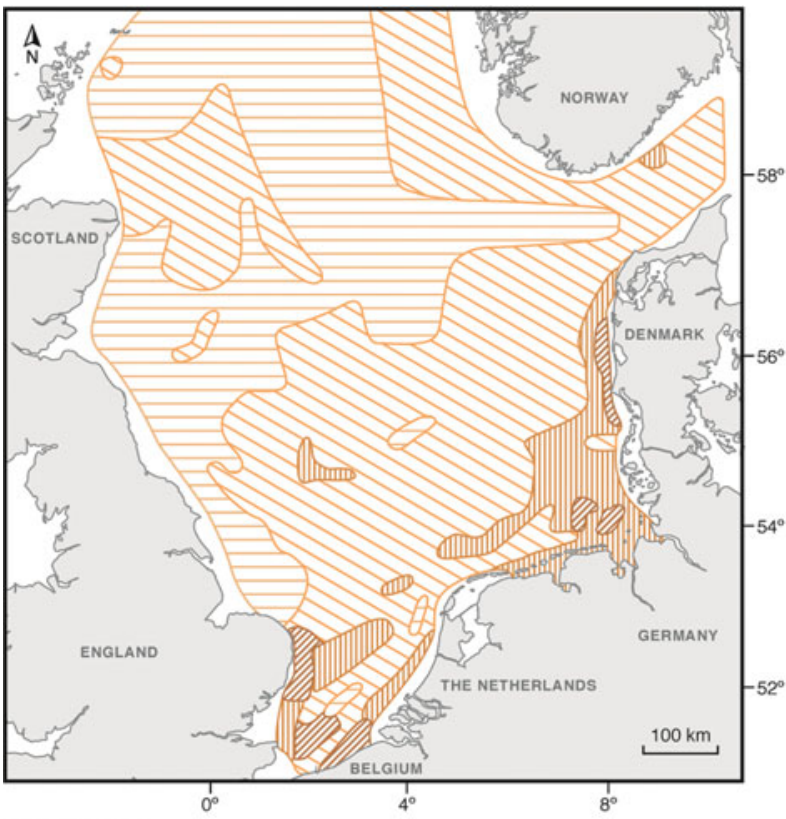

Smectite \%
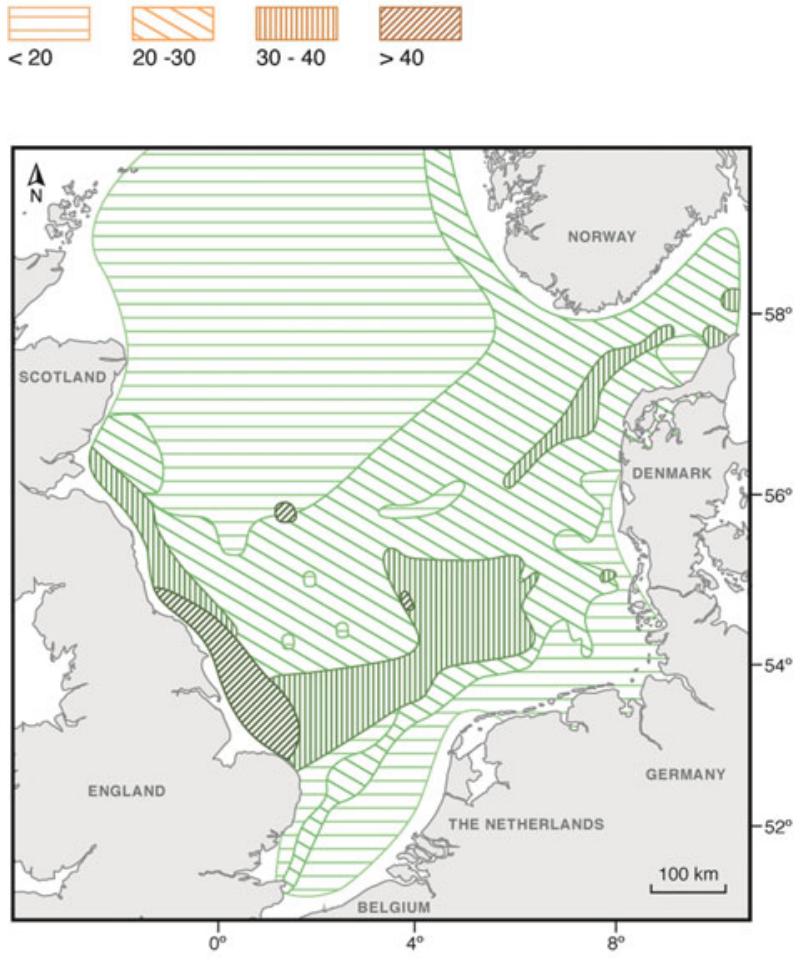

Kaolinite \%

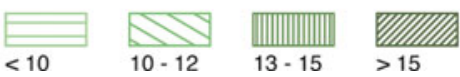

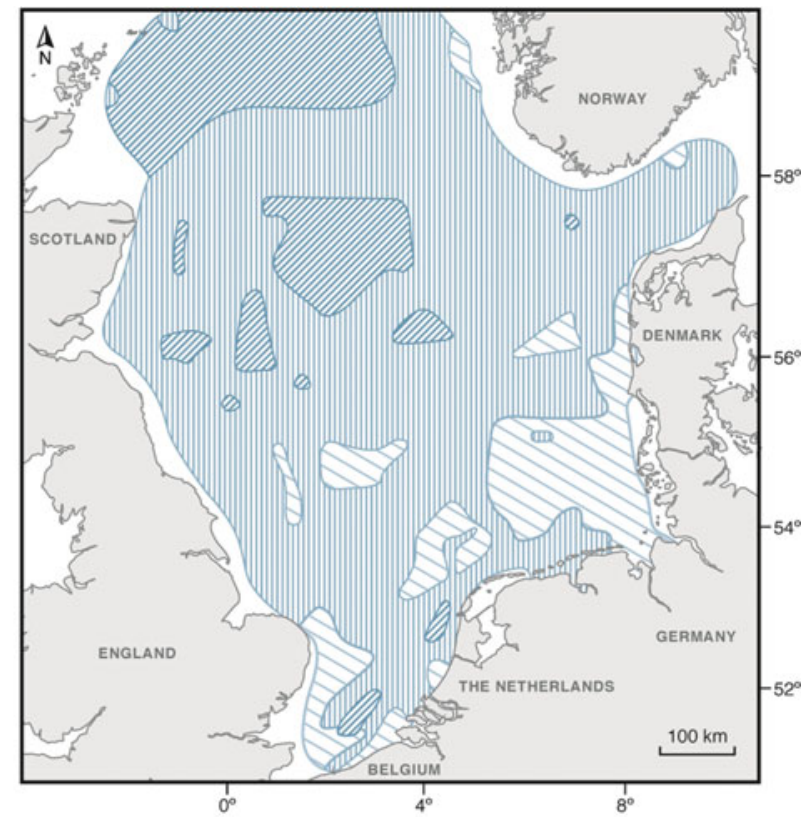

Illite \%
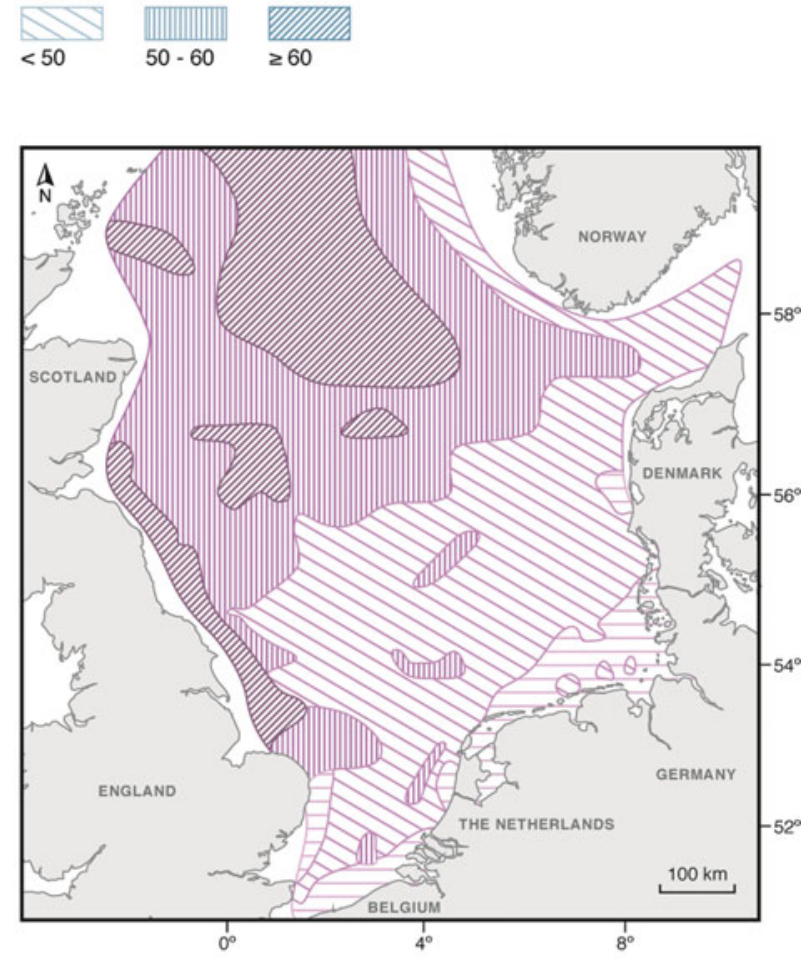

Chlorite \%

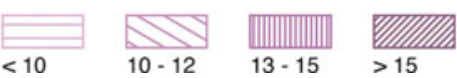

Fig. 10. Maps of the fractions of different clay minerals in the clay fraction of seabed sediments in the North Sea (redrawn from Irion \& Zöllmer, 1999).

coast originates from submarine erosion of the seafloor whereas only $10 \%$ originates from the Ems, Weser and Elbe rivers. Müller \& Forstner (1975) and Irion et al. (1987) even assumed transport of fine-grained uncontaminated sediments from the North Sea as far as Hamburg in the Elbe estuary and a decreasing mixing with the fluvial suspension load to explain the upstream increase in heavy metal contents of the river sediments. By contrast, on the basis of the $\mathrm{K} / \mathrm{Rb}$ and $\mathrm{Mg}$ contents of the illite, Zuther et al. (2000), Pache et al. (2008) and Brockamp \& Clauer (2012) determined that at least $80 \%$ of the sediments off the Weser and Elbe estuaries and nearby coastal areas are of fluvial origin and the rest of marine origin. According to these authors, there seems to have been no transport of large proportions of fine-grained sediment from the North Sea into 
the Weser and Elbe estuaries. Thus the origin of clay minerals in this coastal region remains unclear. However, it is generally agreed that the rate of accumulation in an estuary will depend on the balance of sediment retention to sediment export. This balance will depend on the strength of the sediment transport during ebb tide, which will become less effective with long estuarine residence times, as is the case for the Weser (45 days), Elbe (84 days) and Scheldt (90 days) estuaries (Uncles et al., 2002). This means that it is unlikely that these rivers transport large quantities of fluvial clays into the North Sea.

5.2.3 Palaeogene and Neogene formations. Several studies have paid attention to the clay mineralogy of Palaeogene and Neogene deposits, in particular to the Rupel Clay (also referred to as the Boom Clay in the Netherlands and Belgium). Table 23 summarises the analytical results. The results of Zeelmaekers (2011) and Koenen \& Griffioen (2013) were obtained using a new quantitative approach developed by Zeelmaekers (2011). The data of Kuhlmann et al. (2004) on Pliocene and also Early Pleistocene sediments originates from cores taken in the northern part of the Dutch continental shelf and the rest originates from onshore drillings or quarries (note that the Gelasian stage that was studied is nowadays classified under Pleistocene instead of Pliocene). Kuhlmann's data indicates very variable clay mineral assemblages along the depth profiles: the fractions vary by $50 \%$ for three clay minerals, which indicates large heterogeneity within this $600 \mathrm{~m}$ long sequence. The results for the Rupel or Boom Clay are reasonably consistent, except for the high kaolinite fraction and the low interstratified illite/smectite and smectite fractions found by Heederik et al. (1989). The Ypresian clay has larger fractions of smectite and interstratified illite/smectite than the rest (Zeelmaekers, 2011).

The shifts in clay mineral assemblage at the geological time scale were primarily explained in terms of provenance control by both Kuhlmann et al. (2004) and Zeelmaekers (2011). Climate factors seem to affect the contribution of individual hinterlands, but the climate dependency of weathering of clay minerals is believed to be of minor importance. According to Zeelmaekers (2011), the high smectite fraction in the Ypresian clay can be attributed to a contribution of basic pyroclastic material related to the opening of the North Atlantic and connectivity with the North Sea (cf. Nielsen et al., 2015). A remarkable difference between these smectites and the other clays in the samples studied is that the smectites are authigenic whereas the other clay minerals usually have a detrital origin. The shifts in the clay mineral assemblage of the Late Pliocene record have been attributed to shifts in the supply of predominantly illite and chlorite from Scandinavian sources during cold periods versus predominantly smectite from southern sources during warmer conditions. Shifts in the clay mineral assemblage can also be recognised in the Rupel or Boom Clay. Zeelmaekers (2011) noted a higher kaolinite fraction for the more clayey in- tervals than the more silty intervals, following a Milankovitch cyclic pattern; Koenen \& Griffioen (2013) noted more kaolinite/smectite mixed layers and smectite in the samples that had a higher clay content with less interstratified illite/smectite and illite.

\subsection{Feldspars, micas and silica}

5.3.1 Feldspars and micas. The occurrence of feldspars and micas in marine sediments has received little attention, as is also the case for fluvial sediments. Druif (1927) observed all three feldspars, orthoclase, microcline and plagioclase, microscopically in two Holocene marine sand samples and found orthoclase to be the most abundant. Muscovite and biotite were found together in one sample but not in the other one. For three Tertiary sand samples in Limburg, he observed orthoclase and muscovite, no biotite and plagioclase and few or very few microcline in the two Oligocene samples. Using XRD, Bouezmarni \& Wollast (2005) identified albite and microcline in bottom sediments of the Scheldt: the amounts were higher in the 8-63 $\mu \mathrm{m}$ fraction than in the $<8 \mu \mathrm{m}$ fraction. Also based on XRD analysis, Koenen \& Griffioen (2013) reported 0.3-5.6\% plagioclase and $2.2-11 \% \mathrm{~K}$ feldspar for the Rupel Clay in a series of samples from across the Netherlands. Decleer et al. (1983) found higher contents of $9.8-15.7 \%$ for the unit in Belgium. Both studies indicate substantial presence of the minerals and more prominent presence of $\mathrm{K}$ feldspar over Na feldspar or Ca feldspar. The most extensive investigation on feldspars and micas in the marine environment we are aware of was performed by Crommelin (1943). He made optical mineral counts of the light minerals in suspended matter and sediments of the Wadden Sea and some other water systems, often characterising individual grain size classes. Table 24 presents some of the results. The data show the dominance of orthoclase, albite and oligoclase, and minor roles of microcline and Ca-rich feldspar. The overall results indicate that biotite, chlorite and/or muscovite are omnipresent in the $10-50 \mu \mathrm{m}$ fraction and much less in the $>50 \mu \mathrm{m}$ fraction in the marine environment. A comparison between the Wadden Sea, North Sea and river samples indicates that the first two are very similar and the river samples are richer in micas and chlorite. Finally, Huisman \& Kiden (1998) used the $\mathrm{Na}_{2} \mathrm{O}$ content of sediment as an indicator of Na feldspar content. They reported $\mathrm{Na}_{2} \mathrm{O}$-rich marine sediments of the 0osterhout Formation versus $\mathrm{Na}_{2} \mathrm{O}$-poor marine sediments of the 0osterhout and Breda Formations. This difference was attributed to a different weathering intensity and shifts in the provenance. Similar differences were observed for the fluvial sediments from the same geological period (see section 4.3).

5.3.2 Biogenic silica. Quartz is abundant in Dutch sediments. Several kinds of biogenic silica may also be present in sediments: diatom valves, radiolarian, sponge spicules phytoliths and chrysophyceae. Diatoms are frequently studied within the 
Table 23. Clay mineralogy (in wt\%) of Palaeogene and Neogene marine sediments studied in the Netherlands or Belgium. All results are based on the $<2 \mu \mathrm{m}$ fraction of the samples except Decleer et al. (1983), which are based on whole sediment.

\begin{tabular}{|c|c|c|c|c|c|c|c|c|c|c|}
\hline Formation & Samples & Kaolinite & $\begin{array}{l}\text { Kaolinite/ } \\
\text { smectite }\end{array}$ & Smectite & $\begin{array}{l}\text { Illite/ } \\
\text { smectite }\end{array}$ & Illite & Chlorite & Vermiculite & $\begin{array}{l}\text { Glauconite/ } \\
\text { smectite }\end{array}$ & Reference \\
\hline Late Pliocene & 59 & $5-51$ & & $0.5-51$ & & $26-76$ & $4-28$ & & & Kuhlmann et al. (2004) \\
\hline Breda Formation & 6 & $15-25$ & & $10-20$ & $5-15$ & $45-70$ & Traces, degraded & & & Heederik et al. (1989) \\
\hline Voort sands & 5 & & & $25-45$ & $10-15$ & $40-65$ & Traces, degraded & & & Heederik et al. (1989) \\
\hline Rupel Clay (Asten, the Netherlands) & 3 & $30-40$ & & $5-10$ & $5-10$ & $45-50$ & Traces, degraded & & & Heederik et al. (1989) \\
\hline Rupel Clay (the Netherlands) & 26 & $1-12$ & $2-14$ & $3-56$ & $1-45$ & $1-24$ & $1-2$ & & $0-29+79$ & Koenen \& Griffioen (2013) \\
\hline Boom Clay (Mol, Belgium) & 1 & $10-30$ & & $30-50$ & & $30-50$ & $1-5$ & $<1$ & & Breeuwsma et al. (1987) \\
\hline Boom Clay (Belgium) & 21 & $1-9$ & & $19-42$ & & $3-23$ & & & & Decleer et al. (1983) \\
\hline Boom Clay (Belgium) & 19 & $5-12$ & 4-17 & $19-39$ & $19-31$ & $14-25$ & $2-7$ & & & Zeelmaekers (2011) \\
\hline Berg sands & 6 & $5-50$ & & $5-40$ & $5-20$ & $35-45$ & Up to 5 & & & Heederik et al. (1989) \\
\hline Basal Dongen sands & 5 & up to 5 & & $60-65$ & $5-15$ & $20-30$ & Traces & & & Heederik et al. (1989) \\
\hline
\end{tabular}


Table 24. Mineral counts of feldspars and micas (out of 100 grains of light minerals) in sediments and/or suspended matter in the Wadden Sea, the North Sea and the Rhine river (calcite and aragonite were removed prior to counting; derived from Crommelin (1943)).

\begin{tabular}{|c|c|c|c|c|c|c|}
\hline $\begin{array}{l}\text { Grain-size class and } \\
\text { sample type }\end{array}$ & $\begin{array}{l}\text { Orthoclase }+ \\
\text { albite }\end{array}$ & Microcline & Oligoclase & $\begin{array}{l}\text { Basic } \\
\text { plagioclase }\end{array}$ & $\begin{array}{l}\text { Biotite }+ \\
\text { green chlorite }\end{array}$ & $\begin{array}{l}\text { Muscovite }+ \\
\text { colourless chlorite }\end{array}$ \\
\hline $\begin{array}{l}\text { 16-84 } \mu \mathrm{m} \text { suspended matter } \\
\text { Wadden Sea during storm } \\
\text { event }\end{array}$ & $4-22$ & $0-1$ & $1-5$ & $0-2$ & $0-9$ & $41-89$ \\
\hline $\begin{array}{l}\text { 25-50 } \mu \mathrm{m} \text { sediment Wadden } \\
\text { Sea area }\end{array}$ & $7-15$ & 0 & $5-11$ & 0 & $2-7$ & $2-10$ \\
\hline $25-50 \mu \mathrm{m}$ eroded clay layers & $11-16$ & $0-1$ & $5-10$ & 0 & $2-8$ & $3-5$ \\
\hline $\begin{array}{l}\text { 25-50 } \mu \mathrm{m} \text { suspended matter } \\
\text { Ems }\end{array}$ & $11-19$ & $0-1$ & $2-4$ & 0 & $0-2$ & $0-3$ \\
\hline $\begin{array}{l}25-50 \mu \mathrm{m} \text { sea bottom North } \\
\text { Sea }\end{array}$ & $8-18$ & $0-1$ & $3-6$ & 0 & $1-4$ & $1-5$ \\
\hline $\begin{array}{l}25-50 \mu \mathrm{m} \text { suspended matter } \\
\text { Rhine river }\end{array}$ & $11-22$ & 0 & $2-6$ & 0 & $7-12$ & $2-9$ \\
\hline
\end{tabular}

Table 25. Amounts of diatoms in different kinds of Dutch geological sediments.

\begin{tabular}{|c|c|c|c|c|}
\hline Location & Material & Samples & Diatom concentration & Reference \\
\hline Sediment & & & $10^{6}$ valves $/ g($ sed $)$ & \\
\hline Lake IJsselmeer & Recent limnological & 26 & Mostly $150-400$ & Cremer et al. (2009) \\
\hline Lake IJsselmeer & Holocene marine & 7 & c. 50 & Cremer et al. (2009) \\
\hline Haarsteegse Wiel (Meuse River) & Limnological & 44 & $<3$ or $50-100$ & Cremer et al. (2010) \\
\hline Herveld (Waal River) & Fluvial clay & 1 & 30 & Crommelin (1945) \\
\hline Winschoten & Glacial Potklei & 1 & $<0.01$ & Crommelin (1945) \\
\hline IJssel River & Recent fluvial & 1 & $<0.01$ & Crommelin (1945) \\
\hline Various & Holocene marine & 3 & $0.6-3$ & Crommelin (1945) \\
\hline Amsterdam & Eemian marine & 1 & 20 & Crommelin (1945) \\
\hline Harbours, western Netherlands & Brackish, coastal & 5 & $4-10$ & Crommelin (1945) \\
\hline Land van Saaftinge (Scheldt) & Estuarine & 1 & 6 & Crommelin (1945) \\
\hline Wadden Sea & Marine lagoonal & 1 & 3 & Crommelin (1945) \\
\hline Western Scheldt & Recent, intertidal flat & 19 & $15-28$ & Sabbe (1993) \\
\hline Tholen, western Netherlands & Holocene buried peat & $?$ & 0 & Vos \& De Wolf (1993) \\
\hline Ugchelen (diatom slurry) & Limnological (fen) & 1 & $1,000,000$ & Crommelin (1945) \\
\hline Suspended matter & & & $\%$ of suspended matter & \\
\hline Scheldt system & Salinity $<5$ & Total around 150 & Around 5.6 & Carbonnel et al. (2013) \\
\hline Scheldt system & Salinity 5-10 & $\prime \prime$ & Around 3.2 & Carbonnel et al. (2013) \\
\hline Scheldt system & Salinity $>15$ & $\prime \prime$ & Around 4-5 & Carbonnel et al. (2013) \\
\hline
\end{tabular}

context of chronostratigraphy and palaeoenvironmental reconstructions, but absolute contents - the finding most interesting for our review - are not often determined. They are a constituent of fresh and marine phytoplankton and consist of amorphous hydrated particulate silica. Table 25 presents an overview of the amounts of biogenic silica in suspended matter of the Scheldt system and of diatoms in marine or other sediments. The old data of Crommelin (1945) agree fairly well with more recent data of Cremer et al. $(2009,2010)$ and Sabbe (1993). The typical diatom concentration ranges from 1 to several hun- dreds of valves $/ \mathrm{g}_{\text {sed }}$. It appears that lacustrine sediments contain the highest concentrations: this fits in with the general observation that lakes are efficient silica traps (Street-Perrott $\&$ Barker, 2008). The actual concentration depends on the local production versus the external sediment load and possibly compaction. An amount $<10$ valves $/ \mathrm{g}_{\text {sed }}$ has been found for both peat and Potklei, but this finding cannot be generalised, for reasons discussed in section 6 . The fraction of biogenic silica in the suspended matter of the Scheldt system varies around several per cent. Both Sabbe (1993) and Carbonnel et al. (2013) 
found that the concentration of free living diatoms is small by comparison with that associated with suspended matter or sandy sediment grains (and which is largely dead material). On the intertidal flat Sabbe studied, the living diatoms showed strong temporal variations and correlations with sky radiance and percentage organic matter, whereas the dead diatom mass appeared to be stable (Sabbe, 1993). Similarly, the temporal and longitudinal variability of biogenic silica in the Scheldt system was highly related to the variability of the suspended matter, with the lowest fraction occurring in the zone with intermediate salinity (Carbonnel et al., 2013).

The solubility of biogenic silica is about $50 \mathrm{mg} \mathrm{Si} / \mathrm{L}$, which is 17 times higher than that of quartz (Cornelis et al., 2011). Dissolution of biogenic silica in buried sediments may thus be an important source of dissolved silica in groundwater (Miretzky et al., 2001). The weight of diatom valves varies around $5 \times 10^{-11} \mathrm{~g} \mathrm{SiO}_{2}$ /valve (Sané et al., 2013). A concentration of 10 million valves $/ g_{\text {sed }}$ thus corresponds to $500 \mathrm{ppm} \mathrm{Si}$. If the recharge is $350 \mathrm{~mm} / \mathrm{y}$ and no other silica source is present, it would thus take 23 years for a layer of sediment $1 \mathrm{~m}$ thick to be totally depleted of biogenic silica. Leaching of biogenic silica from sediments could therefore be a relevant process at the geological time scale in infiltration areas.

\subsection{Ca carbonates, phosphates and gypsum}

5.4.1 Contents. Calcium carbonates are generally observed in marine deposits and these deposits may also contain shells or shell fragments. In young marine sediments from various coastal areas, Verhoeven (1962) noted an increase in carbonate content from a few per cent to $10-22 \%$ with increasing clay content until $15-30 \%$ clay and a constant content above these levels. The highest contents were found near the Western Scheldt and the lowest at the Zuiderzee, which agrees with the general pattern of $\mathrm{CaCO}_{3}$ decreasing northwards from the French coast to the Danish coast. Table 26 presents percentile data on carbonate contents of marine geological formations, mostly obtained by CS elemental or thermogravimetric analysis. Clay and loam have somewhat higher carbonate contents than sand. An important exception is the Oosterhout Formation, which has high carbonate contents in the sand fraction. This is due to the presence of a Crag facies with over 15\% Ca carbonate, which is classified as sand (Keijzer \& Griffioen, 2012). Crag deposits are sand containing abundant shells and bryozoans; these sediments form the lower part of the 0osterhout Formation in southern and northeastern Netherlands (www.dinoloket.nl). The numbers for the Boom Clay (Decleer et al., 1983) suggest that the carbonate concretions present were not included. Koenen \& Griffioen (2013) also observed that the calcite content in the Rupel Clay is mostly about equal to ( $<10 \%$ difference) or greater than the aragonite content: the maximum calcite content is $25.9 \%$ and the maximum aragonite content is $5.1 \%$. Klein \& Griffioen (2012) showed that in the northern Netherlands the carbonate content in the Late Pleistocene Eem Formation is significantly lower than in the Holocene Formation for both clay and sand. These two findings indicate that at the regional scale the marine formations differ substantially in terms of their carbonate characteristics.

Zwolsman (1999) presents the carbonate contents of suspended matter in the Western Scheldt: about 28\% for the marine end member, with larger amounts in the winter half year than in the summer half year. A similar gradient was found by Zwolsman (1994) for suspended matter: the $\mathrm{CaCO}_{3}$ fraction is about $20 \%$ for salinity 15 PSU and higher and about $10 \%$ for 0.5 PSU (PSU is practical salinity unit and is a measure of the electrical conductivity of seawater; ocean water has a PSU of approximately 35, being near-equivalent to $35 \mathrm{~g}$ salt $/ \mathrm{kg}$ ).

The highest $\mathrm{CaCO}_{3}$ content is found in the silt fraction of young sediments: more specifically, in the 2-8 $\mu \mathrm{m}$ and 8-16 $\mu \mathrm{m}$ fractions (Verhoeven, 1962; Salomons, 1975) or the 16-43 $\mu \mathrm{m}$ fraction (Zuur, 1936). The clay fraction proves to be relatively poor, having $\mathrm{CaCO}_{3}$ contents that are four to six times lower. The $\mathrm{CaCO}_{3}$ content of the 75-1400 $\mu \mathrm{m}$ and $>1400 \mu \mathrm{m}$ fractions varies somewhat depending on the presence of shell fragments. The material suspended in the Dutch Wadden area and the newly deposited sediments showed nearly the same distribution of $\mathrm{CaCO}_{3}$ over the various grain size fractions. We assume that this is probably true for samples that contain only detrital carbonate and no or few authigenic shell fragments, since the shell fragments are usually larger than $200 \mu \mathrm{m}$ (Eisma, 1968). Conclusions on carbonate gradients for young sediments within the southwestern estuaries are conflicting. Verhoeven (1962) and Salomons (1975) conclude that the $\mathrm{CaCO}_{3}$ content of estuarine deposits of the Western Scheldt decreases with decreasing salinity, where the relation between content and grain size class remains about the same. Beeftink et al. (1977) do not observe a significant correlation between carbonate content in tidal marshes and distance from the North Sea. They attribute this to differences in diagenetic decalcification under different local environmental conditions that may obscure the regional depositional gradient.

Note that prior to routine grain size analysis, carbonate is often removed together with organic matter because authigenic carbonate may cement individual grains into aggregates. This removal has two implications: (1) for many kinds of calcareous sediment there is a systematic difference in grain size distribution between original sediment and analysed sediment, and (2) in a considerable fraction of carbonate-rich sediment the true grain size distribution is unclear. Geologists are traditionally interested in the grain size distribution of the ensemble of individual grains. However, for hydrogeologists and geochemists the actual grain size distribution may be more relevant, for example in order to deal with permeability and carbonates.

It is worth pointing out that Druif (1927) microscopicaly observed apatite in 'normal amounts' in two marine sand samples. 
Table 26. Regional characteristics (as percentiles) of the pyrite, reactive Fe, organic matter and Ca carbonate contents in several Dutch marine geological formations. Geotop refers to the first tens of metres below surface and $5 a 2$ and $5 b 2$ are two of these areas (see Van Gaans et al. (2011) and Griffioen et al. (2013)). Note that 82.5 percentile is given in regular or 90 percentile in italic script.

\begin{tabular}{|c|c|c|c|c|c|c|c|c|c|c|c|c|c|}
\hline \multirow[b]{3}{*}{ Formation } & \multirow[b]{3}{*}{ Region } & \multirow{3}{*}{$\begin{array}{l}\text { Depth } \\
\text { (m) }\end{array}$} & \multirow[b]{3}{*}{ Samples } & \multicolumn{3}{|c|}{$\begin{array}{l}\text { Pyrite } \\
(w t \%)\end{array}$} & \multicolumn{2}{|c|}{$\begin{array}{l}\text { Reactive } \\
\text { Fe (wt } \%)\end{array}$} & \multicolumn{2}{|c|}{$\begin{array}{c}\text { Organic } \\
\text { matter (wt\%) }\end{array}$} & \multicolumn{2}{|c|}{$\begin{array}{c}\text { Ca carbonate } \\
(w t \%)\end{array}$} & \multirow[b]{3}{*}{ Reference } \\
\hline & & & & \multirow{2}{*}{\multicolumn{2}{|c|}{$\mathrm{p} 50$}} & \multirow{2}{*}{$\begin{array}{l}\mathrm{p} 82.5 \\
\text { or } \mathrm{p} 90\end{array}$} & \multirow[b]{2}{*}{ p50 } & \multirow{2}{*}{$\begin{array}{l}\mathrm{p} 82.5 \\
\text { or } \mathrm{p} 90\end{array}$} & \multirow[b]{2}{*}{$\mathrm{p} 50$} & \multirow{2}{*}{$\begin{array}{l}\text { p82.5 } \\
\text { or p90 }\end{array}$} & \multirow[b]{2}{*}{$\mathrm{p} 50$} & \multirow{2}{*}{$\begin{array}{l}\mathrm{p} 82.5 \\
\text { or } \mathrm{p} 90\end{array}$} & \\
\hline & & & & & & & & & & & & & \\
\hline \multicolumn{14}{|l|}{ Clay samples } \\
\hline Naaldwijk & Holland & Geotop & 231 & 1.8 & & 3.7 & 1.24 & 2.66 & 1.78 & 4.02 & 13.07 & 18.98 & Van Gaans et al. (2007) \\
\hline Naaldwijk & Holocene N-NL 5a2 & Geotop & 34 & 1.1 & & 2.6 & 0 & 0.2 & 2 & 3.8 & 3.8 & 7.2 & Klein \& Griffioen (2012) \\
\hline Naaldwijk & Holocene N-NL 5b2 & Geotop & 103 & 1 & & 2.9 & 0.2 & 0.8 & 2.2 & 4.5 & 6.2 & 11.1 & Klein \& Griffioen (2012) \\
\hline Naaldwijk & Zeeland & Geotop & 30 & 1.1 & & 2.1 & 0.2 & 0.9 & 2.7 & 4.1 & 4 & 9.1 & Vermooten et al. (2011) \\
\hline Eem & Holocene N-NL 5b2 & Geotop & 22 & 1.2 & & 2 & 0.4 & 1.3 & 2.6 & 4.6 & 1 & 2.2 & Klein \& Griffioen (2012) \\
\hline Oosterhout & Zeeland & Geotop & 5 & 0.6 & & - & 2 & - & 2.6 & - & 2.7 & - & Vermooten et al. (2011) \\
\hline Boom Clay & Mol (B) & $170-260$ & $10 / 14$ & $1.5 \pm 0.3$ & & & & & $1.23 \pm 0.41 \sim$ & & 0.5 to 1.0 & & Baeyens et al. (1985) \\
\hline Boom Clay & Flanders (B) & Clay pits & 21 & $1.5 \pm 0.5$ & & & & & $1.66 \pm 0.90 \sim$ & & $0.9 \pm 1.2$ & & Decleer et al. (1983) \\
\hline Rupel Clay & throughout NL & $168-650$ & 30 & 0.5 & & 1.0 & & & 1.6 & 2.4 & 2.4 & 8.9 & Klein \& Griffioen (2013) \\
\hline \multicolumn{14}{|l|}{ Loam samples } \\
\hline Naaldwijk & Holocene N-NL 5a2 & Geotop & 14 & 1.2 & & 2.4 & 0 & 0.4 & 1.9 & 3.4 & 6 & 10.5 & Klein \& Griffioen (2012) \\
\hline Naaldwijk & Holocene N-NL 5b2 & Geotop & 31 & 1.2 & & 2.7 & 0.4 & 0.9 & 2.8 & 4.9 & 6.1 & 10.1 & Klein \& Griffioen (2012) \\
\hline Naaldwijk & Zeeland & Geotop & 34 & 1.1 & & 2.1 & 0.4 & 0.8 & 3.1 & 4.2 & 4.2 & 6.2 & Vermooten et al. (2011) \\
\hline Eem & Holocene N-NL 5b2 & Geotop & 12 & 1.2 & & 2 & 0.4 & 0.7 & 2.9 & 4 & 4.7 & 5.5 & Klein \& Griffioen (2012) \\
\hline \multicolumn{14}{|l|}{ Sand samples } \\
\hline Naaldwijk & Holland & Geotop & 125 & 0.61 & & 1.9 & 0.43 & 0.85 & $<$ d.l. & 1.49 & 8.67 & 16.03 & Van Gaans et al. (2007) \\
\hline Naaldwijk & Holocene N-NL 5a2 & Geotop & 16 & 0.4 & & 0.8 & 0 & 0 & 1 & 1.8 & 2.3 & 5.1 & Klein \& Griffioen (2012) \\
\hline Naaldwijk & Holocene N-NL 5b2 & Geotop & 59 & 0.3 & & 0.8 & 0 & 0.2 & 0.9 & 1.7 & 3.1 & 8.5 & Klein \& Griffioen (2012) \\
\hline Naaldwijk - Walcheren M & Zeeland & Geotop & 87 & 0 & & 0.1 & 0.3 & 0.5 & 0.4 & 0.9 & 3.1 & 5.6 & Vermooten et al. (2011) \\
\hline Naaldwijk - Wormer M & Zeeland & Geotop & 43 & 0.2 & & 0.5 & 0.1 & 0.1 & 0.5 & 1.3 & 2.8 & 5.9 & Vermooten et al. (2011) \\
\hline Oosterhout & Zeeland & Geotop & 19 & 0 & & 0.2 & 1.6 & 2.1 & 0.7 & 1.3 & 11.6 & 26.6 & Vermooten et al. (2011) \\
\hline Eem & Holocene N-NL 5b2 & Geotop & 20 & 0.3 & & 0.7 & 0.1 & 0.5 & 0.5 & 2.1 & 0.7 & 3 & Klein \& Griffioen (2012) \\
\hline Breda & Peel Horst & Buried & $66 / 34$ & 0.34 & & 1.8 & 1.2 & 4.5 & 0.21 & 0.77 & $<$ d.l. & 1.1 & Bakker et al. (2007) \\
\hline Breda & Brabant & $>60$ & & c. 0.5 & & & & & & & & & Huisman \& Kiden (1998) \\
\hline Maassluis & Brabant & $>60$ & & c. 0.4 & & & & & & & & & Huisman \& Kiden (1998) \\
\hline Oosterhout & Brabant & $>60$ & & c. 0.5 with & xtreme of 2 & & & & & & & & Huisman \& Kiden (1998) \\
\hline Boom Clay - S60 horizon & Boom (B) & Quarry & & $0.7-1.1$ wi & $\max$ of 3.2 & & & & & & & & Laenen \& De Craen (2004) \\
\hline
\end{tabular}


Remarkable is the presence of U-rich phosphorite nodules in sands of the Breda Formation in Zeeland (Harseveldt, 1973). Based on 12 samples, the content of $\mathrm{Ca}$ phosphate varies between 25 and $69 \mathrm{wt} \%$ expressed on the basis of $\mathrm{Ca}_{3}\left(\mathrm{PO}_{4}\right)_{2}$. The layers containing the nodules appear to be discontinuous. The nodules are composed of light green glauconite globules, quartz grains and some feldspar grains embedded in a cryptocrystalline matrix of apatite.

5.4.2 Provenance of carbonates. Calcium carbonate in marine deposits may originate from fluviatile carbonates, carbonates derived from eroded carbonate formations along the coast (as in the Dover Strait), recent biogenic carbonates (such as shells) and also authigenic carbonate (Salomons, 1975; Kooistra, 1978; Fig. 11). Salomons (1975) characterised recent marine and estuarine carbonates according to their mineralogical and isotopic composition, using sediment samples with $50 \%$ of the grains less than $<20 \mu \mathrm{m}$. The recent biogenic carbonates are high-Mg calcite and aragonite, both having a high ${ }^{14} \mathrm{C}$ content. Salomons could not detect aragonite and he found that the average ${ }^{14} \mathrm{C}$ content of recent sediments in the Wadden Sea area or southern part of the North Sea varied around 24-36 PMC. This implies that recent biogenic carbonate is not an important constituent of these recent marine sediments as its radiocarbon content is close to $100 \mathrm{PMC}$. The $\delta^{13} \mathrm{C}$ value was around $0 \%$ whereas that for the recent Rhine-Meuse sediments was $-3.5 \%$ and for the Ems sediments it was $-0.5 \%$ (Table 11). This is further evidence that the recent marine sediments mainly originate from eroded carbonate formations along the coast. Salomons (1975) estimated the contribution from the rivers Rhine and Meuse to the sediments in the Wadden Sea is no more than $20 \%$. Verhoeven (1962) mentions a microscopy study of Favejee on the biogenic $\mathrm{CaCO}_{3}$ particles in various grain size classes. The bulk of the particles could not be determined, but shell fragments, Foraminifera, Ostracoda and species of Echinodermata were found, and the fine fractions below $16 \mu \mathrm{m}$ in particular contained some rhombohedral crystals and fine, needle-shaped particles. By contrast, Bouezmarni \& Wollast (2005) found calcite and aragonite in comparable amounts in superficial sands of the Scheldt estuary and only calcite in the muddy sediments. Micromorphological investigation indicated that the latter calcite occurred as rhombohedral crystals, which were authigenically formed particularly in relation to sulphate reduction within anoxic zones of the estuary.

The carbonates in the Rhine-Meuse estuary before closure by the Delta works and the Ems estuary had a high marine fraction. According to Salomons (1975), the proportion of carbonate derived from a marine environment was more than $40 \%$ for the Hollands Diep, about $70 \%$ for the Haringvliet and up to $90 \%$ for the Ems estuary. Similarly, the results of Verlaan et al. (1998) show that Ca as carbonate in suspended matter of the Scheldt estuary is predominantly of marine origin and its influence extends throughout the entire brackish-water zone. $\delta^{13} \mathrm{C}$ analysis of carbonate in samples from the marine 0osterhout and Breda Formations also yielded values close to zero, which points to a marine origin for these much older Neogene deposits too (Hartog et al., 2005).

5.4.3 Shells. Shells are authigenically grown Ca carbonates which are commonly found in marine sediments. The topic of shell production has received considerable interest in the context of sustainable harvesting of shellfish and of shells from the Wadden Sea (e.g. Beukema \& Cadée, 1999; De Vries, 2000). The dominant shells in the Wadden Sea originate from cockles (Cerastoderma edule), which make up $75-90 \%$ of the total volume of shell produced. The average annual amount of $\mathrm{Ca}$ carbonate produced by adult cockles is $84 \mathrm{~g} / \mathrm{m}^{2}$, amounting to a total of 126 million $\mathrm{kg} / \mathrm{y}$ in the Dutch Wadden Sea (Beukema \& Cadée, 1999). This production rate is equivalent to 189,000 $\mathrm{m}^{3} / \mathrm{y}$, whereas the sedimentation rate at the Dutch Wadden Sea is 9.4 million $\mathrm{m}^{3} / \mathrm{y}$ (Elias et al., 2012). The ratio between these two rates is 0.02 , i.e. the authigenically grown Ca carbonate production is substantial when compared to the Ca carbonate content of a few per cent usually found in marine or estuarine sediments (Table 26).

The destiny of these shells varies: nowadays about $5 \%$ are removed by fishery, an estimated $5 \%$ become more or less permanently buried, about $17 \%$ are fragmented by birds (eider ducks in particular) producing shell fragments of mostly 2-8 $\mathrm{mm}$ and the large remaining proportion is transported to tidal streams, where they form dense accumulations at the bottom (Fig. 12). Beukema \& Cadée (1999) considered physical fragmentation and chemical dissolution to be negligible in the sheltered Wadden Sea environment. Cockle shells are transported only during severe storms, when sufficient energy is present to lift and transport them (De Vries, 2000). The horizontal distances travelled are therefore small. A more important transport mechanism is erosion of intertidal flats by shifting gully channels: the shells become concentrated at the bottom of the gully and the sand is transported away. This results in the formation of shell beds, which may become buried by more permanent movement of gullies at the geological time scale. Geologically, the shells, their fragments and the associated sand may become preserved as channel lag deposits.

5.4.4 Authigenic carbonate and decalcification. Both neoformation of carbonate and decalcification were observed by Kooistra (1978) in recent estuarine sediments. Neo-formation is common in the intertidal flats and decalcification in the medium-high and high supratidal flats. Two morphologies were found for the neoformation: (1) single rhombohedral crystals in the soil matrix and (2) accumulations of fine particles associated with voids. Local evaporation caused the carbonate to precipitate from oversaturated solution. Decalcification is strongly associated with pyrite oxidation, as will be discussed later. 
Fig. 11. Major sources and fluxes of Ca-carbonates in the Rhine-Meuse-Scheldt delta area and related southern North Sea.

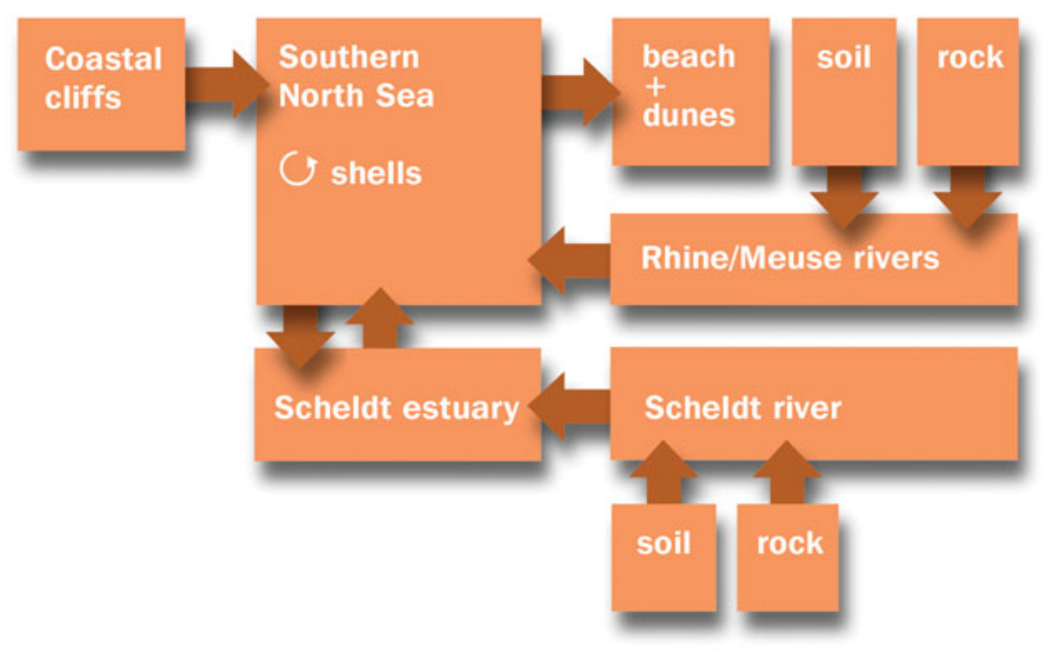

The Boom Clay contains septarian carbonate concretions in several stratigraphical levels (De Craen et al., 1999a,b; Fig. 13), which are always associated with thin bioclast-rich layers. The authigenic carbonate that forms the concretions is dominantly calcite. Siderite is also prominently present in two stratigraphically distinguished horizons. The concretions consist of microcrystals of $1-5 \mu \mathrm{m}$ with associated amounts of pyrite. The oxygen isotopic composition (Table 11) suggests precipitation under marine conditions in association with degradation of organic matter. The organic geochemistry indicates a strong terrigenous input of organic matter and the presence of bacterial mass. The observation that delicate sedimentologial features remained preserved in the concretions indicates that concretions must have grown early in diagenesis. De Craen et al. (1999a) concluded that the concretions were formed due to microbially mediated sulphate reduction with related precipitation of pyrite and calcite, and - to a lesser extent - iron and manganese oxide reduction.

A special phenomenon is the presence of so-called pseudogaylussite (also known under other names such as glendonite), which is typically found in a depth range of one to several metres in young Holocene marine clay deposits of the provinces North Holland, Friesland and Groningen (e.g. Van Baren, 1926; Oenema, 1990c). It mostly appears as elongated monoclinically shaped porous, brittle crystals 1-2 cm long and ochreyellow in colour. They are mainly composed of calcite, which must be pseudomorphologically substituted because calcite has a trigonal-rhombohedral crystal structure. Shearman \& Smith (1990) proposed that the parent mineral is not gaylussite but ikaite. The composition of gaylussite is $\mathrm{Na}_{2} \mathrm{Ca}\left(\mathrm{CO}_{3}\right)_{2} \cdot 5 \mathrm{H}_{2} \mathrm{O}$ and it is typically found associated with evaporites in closed arid basins, as in the Kenyan Rift Valley. Ikaite is composed of $\mathrm{CaCO}_{3} \cdot 6 \mathrm{H}_{2} \mathrm{O}$ and found in cold, estuarine or marine environments such as Greenland. The latter environment is more similar to Dutch conditions, where so-called pseudo-gaylussite and the brittle, porous structure can be explained by loss of crystal water during recrystallisation from ikaite to calcite (Selleck et al., 2007). Ikaite precipitates preferentially over other $\mathrm{CaCO}_{3}$ polymorphs in the presence of elevated alkalinity and dissolved phosphate. Such conditions are found in the coastal provinces of the Netherlands, where they are associated with freshening of marine sediments (Griffioen et al., 2013).

5.4.5 The occurrence of dolomite. Several researchers have studied the occurrence of dolomite in addition to calcite, using XRD, microscopy after pretreatment with $\mathrm{HCl}$ to remove calcite or selective extraction in acid solution. XRD analysis revealed that the carbonates in the sediments of Hollands Diep, Haringvliet, Ems estuary and the Wadden Sea consisted of low-Mg calcite (Mg content $<1 \%$ ) and dolomite, with the dolomite fraction accounting for about $7 \%$ of total carbonate (Salomons, 1975). The percentage of $\mathrm{CO}_{2}$ bound to $\mathrm{Mg}$ is generally about $10 \%$ but may vary up to $22 \%$ (Verhoeven, 1962) or even $30 \%$ (Bruin, 1938) for soil samples from various regions. In grain size classes $>10 \mu \mathrm{m}$, Crommelin (1943) found a widespread occurrence of dolomite in both suspended material and young sediments of the North Sea and Dutch Wadden Sea. The dolomite content can be high locally: up to $10 \%$ of total carbonate or even more in the 10-25 and 25-50 $\mu \mathrm{m}$ classes of samples decalcified prior to microscopical investigation. Dolomite thus mainly occurs in the silt fraction. Morphologically, it occurs as small aggregates or individual rhombohedral crystals. Since little or no dolomite was found in similar grain size classes of suspended material sampled from the rivers Ems and Rhine, Crommelin proposed dolomite as a proxy mineral for marine sediment. The $<2 \mu \mathrm{m}$ fraction of samples from marine or estuarine soils contains 1$6 \%$ carbonates (Van der Marel, 1950). Substantial amounts of dolomite (up to $15 \%$ of total carbonate) were found in tidal flats on the northern coast and negligible amounts (3\% or less of total carbonate) in soils in the southwestern delta area. The 


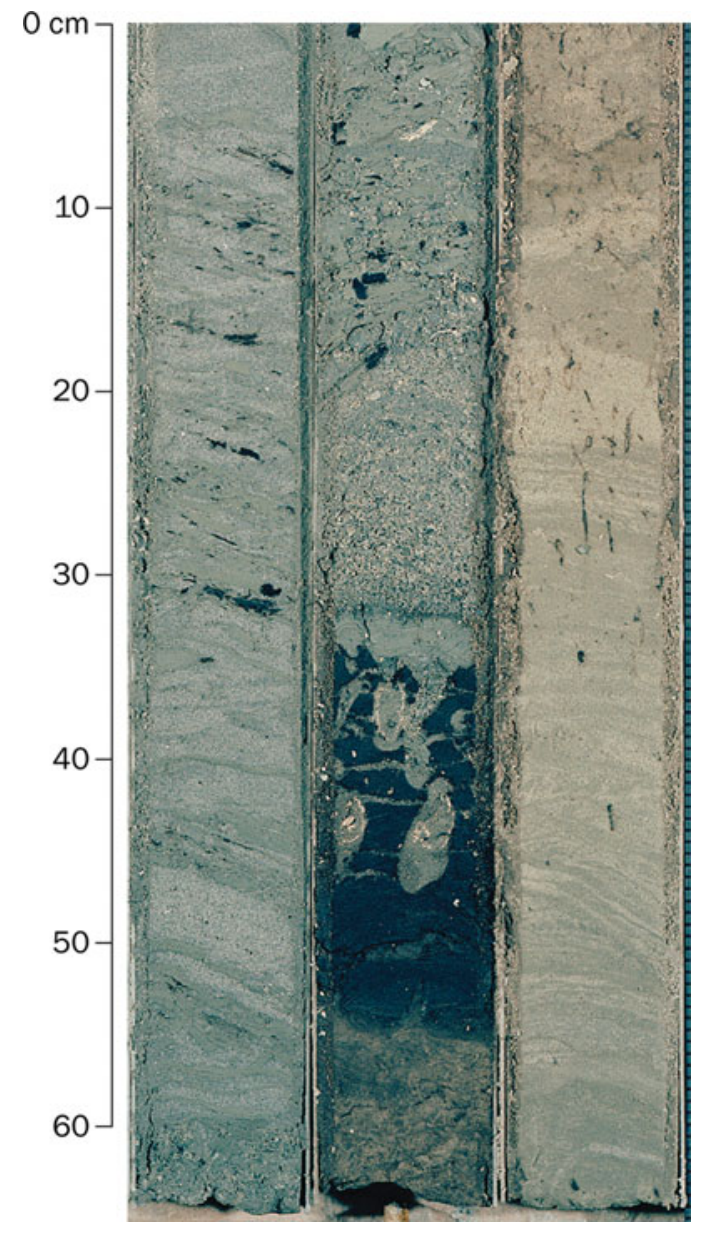

Fig. 12. Sediment cores from drilling B19C0473 at Bakkum (North-Holland) showing in the central core tidal stream deposits with shell fragments on top of a peat layer that features the bioturbation burrows of a mussel.

difference was attributed to a difference in the origin of the parent material: Scandinavian versus French and Belgian. It is worth noting that the $<2 \mu \mathrm{m}$ fraction and the $2-16 \mu \mathrm{m}$ fraction are strongly correlated in marine sediments (Kooistra, 1978; Zuur, 1954) because the finer particles are mostly transported in mud flakes, in which these fractions are present in constant ratios. The dolomite content, however, is distinctly different: high in the 2-16 $\mu \mathrm{m}$ fraction and low in the $<2 \mu \mathrm{m}$ fraction. The relationship of calcite and dolomite with grain size thus differs both between these two minerals and also geographically.

5.4.6 Carbonate in beach sand. The two kinds of beach sand along the coast of North and South Holland are also distinguishable by their carbonate content. The $\mathrm{CaCO}_{3}$ content of beach sands north of Bergen is usually less than $0.25 \%$ whereas south of Castricum the content is usually $2 \%$ or more (Eisma, 1968). The highest contents (up to 12\%) are found between Wijk aan Zee and Noordwijk. The content of the separate sand fractions is lowest in the $250-315 \mu \mathrm{m}$ fraction and increases towards the finer and the coarser fractions. The carbonate content is lower again on the beaches of the islands of South Holland and Zeeland: it may be as low as $<1 \%$. Hot $\mathrm{HCl}$ extractable $\mathrm{Mg}$, which can largely be attributed to carbonates, is around $0.1 \% \mathrm{MgCO}_{3}$ north of Bergen and around $0.4 \% \mathrm{MgCO}_{3}$ south of Bakkum (Eisma, 1968). There is also a north-south difference in $\mathrm{Ca}$ to $\mathrm{Mg}$ ratio: it varies around 3-4 for the northern type of beach sands and around 8 for the southern type. Both the low carbonate content and the low $\mathrm{Ca}$ to $\mathrm{Mg}$ ratio for the northern sands are due to (1) prolonged leaching during Middle Pleistocene to Middle Holocene under terrestrial conditions with preferential dissolution of $\mathrm{Ca}$ from carbonates rather than $\mathrm{Mg}$ and (2) continuing erosion of the coast north of Bergen with little recent deposition of shell fragments on the beach. Another factor controlling the $\mathrm{Mg}$ content and its ratio to $\mathrm{Ca}$ content is the presence of Echinoid fragments, which have a higher $\mathrm{Mg}$ content than mollusc shell fragments. It is interesting that the shell fragments present have a lower size limit of about $200 \mu \mathrm{m}$ while detrital calcite is mainly present in the finer fractions (Eisma, 1968). The shell fragments are formed by biogenic fragmentation of the fragile mollusc shells; physical fragmentation by currents and waves seems to be of minor importance in this environment. The shell fragments do not remain where they were produced but instead accumulate on stable or advancing beach stretches, i.e. south of Bergen. The distribution of whole dead shells and fragments $>1000 \mu \mathrm{m}$ in marine sediments is similar to the distribution of living molluscs, except in the case of a few local secondary accumulations, where finer clastic material has been removed.

5.4.7 Decalcification. Decalcification is observed at shallow depth in supratidal sediments, probably caused by cyclic oxidation of pyrite (Kooistra, 1978). This early diagenetic process may give rise to carbonate deficits in middle-high and high salt marshes. Since no gypsum was observed by Kooistra at these sites (which is in contrast to the findings on reclaimed marine soils), this suggests that good drainage or sufficient washing with sea water has prevented gypsum accumulation. Zwolsman et al. (1993) described two shallow carbonate profiles in brackish supratidal flats: immediately below the surface the carbonate content dropped by $1 \%$ in one profile and by $5 \%$ in the other. At $0.1-0.3 \mathrm{~m}$ depth it increased by $3 \%$ in the first profile and by $6 \%$ in the second profile. The drop happens within the oxic zone and is attributed to a transient drop in $\mathrm{pH}$ resulting from decomposition of organic matter, denitrification and oxidation of iron sulphides. The increase at the greater depth, which was in the reduced zone for one profile studied, is attributed to authigenic carbonate precipitation following an increase in alkalinity on sulphate reduction. The increase in the second profile remained unexplained. Comparably, Vranken et al. (1990) report decalcification rates of 2-8 moles of $\mathrm{CaCO}_{3} /\left(\mathrm{m}^{2} . \mathrm{y}\right)$ for supratidal sediments of the Eastern Scheldt due to predominantly pyrite oxidation. This is equivalent to $0.2-0.8 \% \mathrm{CaCO}_{3} / \mathrm{y}$ for a $20 \mathrm{~cm}$ thick decalcification zone 
Fig. 13. Example of a septarian carbonate concretion in the Boom Clay as observed in a quarry near Leuven (Belgium).

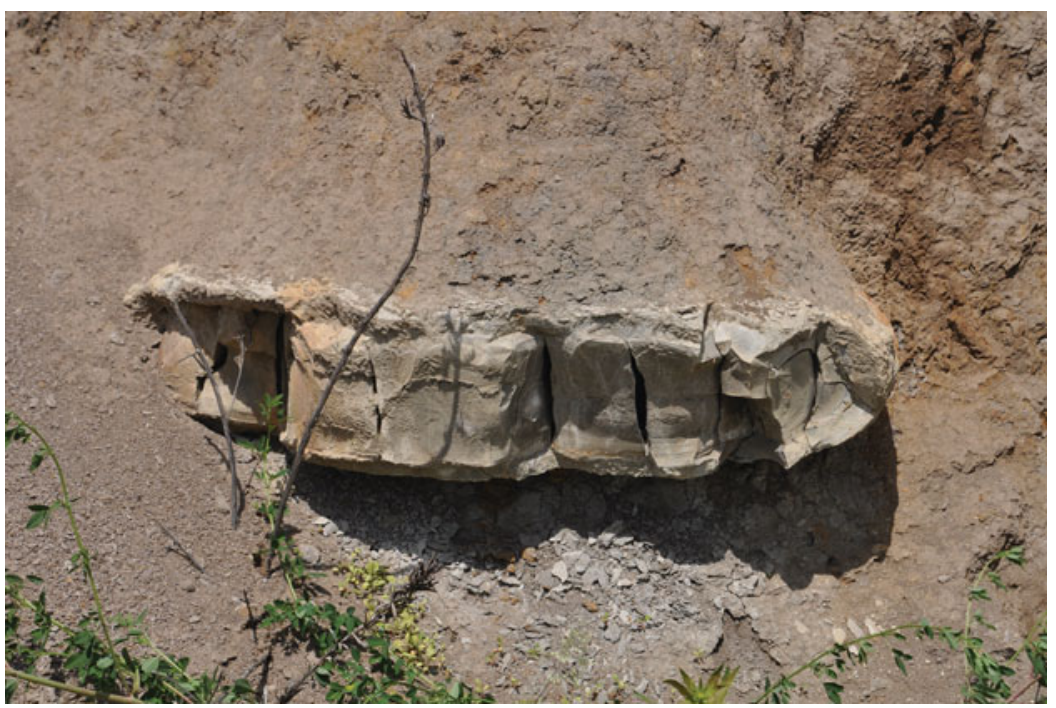

and dry bulk density of $500 \mathrm{~kg} / \mathrm{m}^{3}$ as reported. Substantial decalcification and probably also calcification may thus happen in estuarine sediments in an early diagenetic stage prior to geological burial, from which it can be concluded that the Ca carbonate content of these geological sediments is not only controlled by deposition.

Van der Sluijs (1970) put the decalcification of supratidal flats in a geomorphological perspective. He observed that little decalcification occurred below unvegetated areas whereas decalcification below vegetated parts was high - sometimes even higher than in reclaimed marine clay soils: loss of $12 \% \mathrm{CaCO}_{3}$ per century over a depth of $40 \mathrm{~cm}$ or $6 \%$ per century over a depth of $55 \mathrm{~cm}$. The thickness of the zone deficient in Ca carbonate was observed to be usually less than $40 \mathrm{~cm}$, but thicknesses up to $80 \mathrm{~cm}$ were also observed. He distinguished the levees along the creeks and the pools further inland. In the levees, decalcification is more favourable because of more sandy sediment, greater permeability and less carbonate input during incidental flooding and subsequent settling of marine, calcareous mud. He also explains why thin marine deposits that wedge out against the Pleistocene landscape are generally carbonate-free: such areas are vegetated supratidal flats where conditions for decalcification are favourable and input of marine Ca carbonate is limited due to incidental flooding.

Ritsema \& Groeneberg (1993) described a soil profile of a marine soil in a polder in South Holland, where at $82 \mathrm{~cm}$ depth both calcite and dolomite are present, at $25 \mathrm{~cm}$ depth only dolomite is present and at $2.5 \mathrm{~cm}$ depth both carbonates are absent. This points to the selective dissolution of initially calcite and subsequently dolomite, which is in line with the dissolution kinetics of these two carbonate minerals (Morse \& Arvidson, 2002). The rate of decalcification of reclaimed marine soils will vary depending amongst others on the intensity of pyrite oxidation and its $\mathrm{pH}$ buffering by carbonate (see later). A representative value is provided by Edelman \& De Smet (1951), who suggested $1 \%$ of $\mathrm{CaCO}_{3}$ per 65-90 years for a layer $40 \mathrm{~cm}$ thick.

Subregional patterns in carbonate content have been observed for marine clay soils and attributed to prolonged decalcification after cultivation. For example, Spijker (2005) separates topsoils in Zeeland into calcareous heavy clays and noncalcareous heavy clays based on XRF analyses of Al and $\mathrm{Ca}$ as proxies for clay content and carbonate content, respectively. Within Zeeland province, the calcareous heavy clays are found in southern Noord-Beveland and western Zeeuws Vlaanderen, whereas the non-calcareous heavy clays occur in Walcheren and Schouwen-Duiveland. Care must be taken to attribute differences in carbonate content between polders to the duration of cultivation after reclamation, as the parent material may also differ in carbonate content (Edelman \& De Smet, 1951; Van der Sluijs, 1970).

Gypsum may be found at shallow depth in calcareous, marine soils of northern and western polders. It is authigenically formed by extensive oxidation of pyrite and $\mathrm{pH}$ buffering by $\mathrm{Ca}$ carbonate dissolution. Miedema et al. (1973) observed gypsum at a depth of $1 \mathrm{~m}$, which is the deepest depth of the seasonally fluctuating groundwater table. SEM investigation showed that it occurred as secondary crystals along large channels or as crystal tubes filling channels, through which oxygen enters the soils. The amount of gypsum probably depends on the initial $\mathrm{Ca}$ carbonate content versus pyrite content. Prolonged cultivation of soils containing secondary gypsum may dissolve all gypsum formed.

\subsection{Reactive Fe minerals: sulphides, oxyhydroxides, carbonates and glauconite}

5.5.1 Fe oxyhydroxides. As was the case for fluvial sediments, mineralogical studies on Fe oxides in marine sediments are rare. Most attention has been paid to the occurrence of oxides in 
relation to sulphide oxidation, which is discussed in the next section. Nelson \& Niggli (1950) isolated opaque grains and performed XRD analysis on two samples of beach sand and one Early Holocene marine sand from further inland. In the beach samples, ilmenite and rutile were dominant in about similar proportions and together comprised $80 \%$ of the heavy mineral fraction. Magnetite and little ilmenite were present in the magnetic subfraction. In the inland sample, no Fe oxides were observed as opaque minerals but pyrite was. This illustrates that diagenesis of reactive Fe minerals also might affect the opaque mineral fraction of sediments.

As mentioned earlier, two types of beach sand are distinguished in the Netherlands based on mineralogical composition. Dithionite-extractable $\mathrm{Fe}$ is around $0.03 \% \mathrm{Fe}_{2} \mathrm{O}_{3}$ north of Bergen and around $0.10 \%$ south of Bakkum (Eisma, 1968), which is relatively low (cf. Table 13). This Fe occurs as Fe oxide coating also because the Fe in heavy minerals is negligibly soluble in dithionite. XRD analysis has shown that goethite is present but amorphous material is more abundant. Eisma (1968) related the difference to release from sediment particles in the RhineMeuse estuary and subsequent flocculation of Fe hydroxides with longshore transport and sedimentation, predominantly as far as IJmuiden. This release might be associated with degradation of fluvial organic matter under marine conditions (Eisma, 1986). Van Straaten (1954) mentions that gravel-sized concretions of iron hydroxides occur incidentally at the foot of marsh cliffs, where they became concentrated after erosion of the salt marshes. They were mainly formed in these marshes at faunal channels (see section 5.5.3).

Dehairs et al. (1989) and Turner et al. (1991) addressed the variability of Fe oxides in suspended matter of the Scheldt estuary and North Sea, respectively. Turner et al. (1991) used selective oxide extraction and found that extractable Fe varied around $3 \mathrm{mg} / \mathrm{g}$ and extractable $\mathrm{Mn}$ around $0.7 \mathrm{mg} / \mathrm{g}$ (to convert to wt\% of $\mathrm{Fe}_{2} \mathrm{O}_{3}$, multiply by 0.1436$)$. In the Scheldt samples, Fe had a maximum of about $4 \mathrm{mg} / \mathrm{g}$ at 2-5\% salinity and $\mathrm{Mn}$ has a maximum of about $1 \mathrm{mg} / \mathrm{g}$ at $15-25 \%$ salinity. These maxima were explained by oxidation of dissolved Fe(II) and $\mathrm{Mn}$ (II) downstream of the anoxic zone in the Scheldt estuary and associated settling, where Fe(II) oxidises more rapidly than Mn(II). Dehairs et al. (1989) used non-selective acid leaching and interpreted the variability in $\mathrm{Fe} / \mathrm{Al}$ and $\mathrm{Mn} / \mathrm{Al}$ ratios in terms of variability in the contents of Fe and Mn oxides. A seasonal variability was observed, with the lowest ratios occurring during April-May and the highest during OctoberFebruary. Sediments from the top layer generally exhibited the inverse temporal trend. This fluctuation was attributed to phytoplankton bloom in spring with oxic top sediment during this season, and to mineralisation of fresh settled organic matter with anoxic conditions of the top layer, reductive dissolution of Fe and Mn oxides, related release to the seawater above and subsequent re-oxidation in the water during the rest of the year.
Extractable Fe oxides in the bottom sediments of the southern North Sea and Skagerrak were studied by Slomp et al. (1997). They found the highest contents of around 11,000 mg $\mathrm{Fe} / \mathrm{kg}$ at the Skagerrak, where there is large input of terrigenous material. The content varied around $3000 \mathrm{mg} / \mathrm{kg}$ in the German Bight (where input is also large) and in the zones with sand where erosion is dominant, and it was between 600 and 3000 $\mathrm{mg} / \mathrm{kg}$ in the zones with fine sands and temporary deposition of organic matter. Slomp et al. (1997) noted that most North Sea sediments are relatively poor in Fe oxides, but comparison with the data in Table 13 indicates that the contents are the same order of magnitude as those for Dutch fluvial sediments.

5.5.2 Fe sulphides. Several researchers have observed that suspended matter and also fresh mud in both the Scheldt area and the Wadden Sea contain up to 1\% pyrite (Harmsen, 1954; Kooistra, 1978; Verlaan et al., 1998; Zwolsman \& Van Eck, 1999). This is attributed to resuspension of recent reduced sediments, erosion of non-recent sediments and dredging activities. Both Verlaan et al. (1998) and Zwolsman \& Van Eck (1999) noted that the maximum pyrite content is found in the upper, brackish part of the Scheldt estuary (between Rupelmonde and the Dutch-Belgian border), where the salinity is about 5\%. Data from Oenema (1990a) indicate that the pyrite content in anoxic recent marine sediments can be up to $2-3 \%$, and attribute this to in situ sulphidation. The contents are rather invariant with depth down to $80 \mathrm{~cm}$ deep.

Harmsen (1954) analysed topsoil samples from polders reclaimed from the sea to ascertain their sulphur contents. He found that some old and well-aerated soils contained significant percentages of pyrite while in others pyrite was absent. No reason for this difference could be observed. He postulated that the difference in reactivity was the result of a retarding process, possibly the formation of insoluble Fe(III) phosphate (cf. Elsetinow et al., 2001).

Buried marine sediments contain pyrite, as evidenced by their $\mathrm{S}$ contents, data from micromorphological investigations and the reactivity of the sediments in aerobic incubations. Table 26 presents statistical data on the pyrite and reactive Fe contents obtained from total elemental analysis. The Dutch samples were classified into lithological class, geological formation, geographic region and sometimes also sedimentary facies. The values are based on samples ranging in number from 10 to 172 . The pyrite content is usually below $1 \%$ for sand and several per cent for clay and loam. However, extreme pyrite contents of around 10\% may also be encountered in clay from the Naaldwijk Formation. These outliers are for the Wormer Member of the Naaldwijk Formation in Zeeland associated with organic-rich loam immediately below peat (Keijzer \& Griffioen, 2012). The calculated reactive Fe content that is not associated with pyrite is higher in the Neogene Breda and Oosterhout Formations than in the Quaternary Eem and Naaldwijk Formations. The total amount of reactive Fe is thus also higher in 
these Neogene formations, which implies larger reaction capacities in redox processes (Huisman \& Kiden, 1998; Keijzer \& Griffioen, 2012). The presence of reactive Fe minerals other than pyrite may thus be considerable and differs among geological formations. No other quantitative information exists on the occurrence of these reactive Fe minerals. However, some qualitative information is available on the occurrence of siderite and glauconite in marine sediments, as discussed below. It is also unknown whether the presence of reactive Fe can be attributed to Fe oxides that are not accessible for reductive dissolution of Fe oxides, as concluded from depth profiles of pyritisation in shallow recent marine sediments (0enema, 1990a).

Statistically significant differences between sands of the Wormer and Walcheren Members have been found in the cumulative frequency distribution of both pyrite and non-pyrite reactive Fe for the Naaldwijk Formation in Zeeland (Vermooten et al., 2011). Similar differences were observed for the loam and clay groups, but this was not tested on significance because the data groups were too small. The two members have a comparable sedimentary genesis (De Mulder et al., 2003). Compared with the Wormer Member, the Walcheren Member has substantially lower pyrite contents, lower contents of sedimentary organic matter and higher contents of non-pyrite reactive Fe. The Walcheren Member is younger and the degree of pyritisation is apparently less in these younger sediments. By contrast, no statistically significant differences in cumulative frequency distribution of these three variables were found between the Naaldwijk and Eem Formations in the Northern Netherlands (Klein \& Griffioen, 2012). Comparison between the data for marine and fluvial or other sediments (Tables 8 and 26) revealed that the marine formations have higher pyrite contents, which may or may not be statistically significant (Vermooten et al., 2011; Klein \& Griffioen, 2012). The non-pyrite reactive Fe contents are comparable, but no significant differences were found.

Two drillings deeper than $60 \mathrm{~m}$ in North Brabant revealed that the Breda, Maassluis and Oosterhout Formations contain less than $0.5 \% \mathrm{~S}$ with sporadic isolated peaks up to around $1 \%$, which are often related to organic-rich layers (Huisman \& Kiden, 1998). These peaks often do not coincide with the total Fe peaks. This leaves open the question of what the speciation is of the reactive Fe and whether sufficient reactive Fe is present to bind all $S$ as pyrite or elemental S. For sand samples from the Neogene Oosterhout and Breda Formations, Hartog et al. (2005) found that oxygen consumption during incubation experiments must be attributed to both pyrite and sedimentary organic matter oxidation. The samples contained only $0.1-0.2 \% \mathrm{~S}$. Laenen \& De Craen (2004) report pyrite contents of $0.7-1.0 \%$, with one extreme of $3.2 \%$ for one stratigraphical horizon of the Boom Clay in Belgium that contains siderite. This horizon was studied in Belgium and it is unknown whether this stratigraphical horizon occurs in the Netherlands and, if so, how far northwards. The Boom Clay is also present in the Netherlands (stratigraphically classified as the near-equivalent Rupel Clay; De Mulder et al., 2003) and is a potential host rock for the disposal of high-level radioactive waste.

5.5.3 Micromorphology of pyrite and Fe oxides. Kooistra (1978, 1981) micromorphologically characterised the redoximorphic features of recent sediments in the Eastern Scheldt and related these diagenetic features to the pedogenic development at the plot scale. Three major occurrences for framboidal pyrite were distinguished: (1) as individual spheres, (2) as amoeboidal pyrite and (3) as pseudomorphs in root remains, peat fragments and detrital grains. Amoeboidal pyrite is described as aggregates of framboids in which smaller framboids are joined to a large framboid or interconnect two larger framboids. A fourth, minor type was idiomorphic, most probably cubic, having diameters less than $25 \mu \mathrm{m}$. It was rare, found only in high-lying salt marshes. A range of transitions from a few pyrite framboids to complete occupation with framboids was found in identical sedimentary peat fragments with black components, which indicates that organic matter serves as substrate for sulphate reduction. It is nowadays recognised that framboids form under high supersaturation, so that the nucleation rate is greater than the crystal growth (Ohfuji \& Rickard, 2005). They form when aqueous FeS clusters react via the $\mathrm{H}_{2} \mathrm{~S}$ or polysulphide mechanism, and not directly from solid mackinawite or greigite as was long assumed (Rickard \& Morse, 2005).

The diameters of the individual microlites in the framboids range from 0.5 to $1.5 \mu \mathrm{m}$. Pyrite spheres (diameter $<12-25$ $\mu \mathrm{m})$ were also found in suspended matter from tidal streams and fresh sediments associated with organic-rich mud flakes and in peat and detritus grains. This implies that pyrite may become eroded, transported and locally deposited, i.e. not all pyrite is thus formed strictly in situ. The framboidal spheres are most common in the recent marine sediments. Amorphous $\mathrm{Fe}$ sulphides are present between the spheres. Clusters of pyrite spheres were observed in organic matter and in clay sediment, where much fine-grained organic matter was present. Amoeboidal pyrite consists of spheres with diameters between 20 and $80 \mu \mathrm{m}$ that represent growing phases, being found in root remains and clay sediments in the reduced zone.

Black components were also observed to be particularly associated with organic material. Energy dispersive X-ray analysis indicated that these may be amorphous Fe sulphides or amorphous Mn oxides. Red ferric iron accumulations occurred in the intertidal and supratidal sediments as coatings or altered coatings around pyrite accumulations and associated with $\mathrm{Mn}$ accumulations. Phosphorus was also present in these accumulations, often in association with Ca. They occurred where aeration was possible, which implies that they are found in specific zones. They were composed of amorphous Fe hydroxide or goethite and found in the intertidal flats, natural levees and basins of the middle-high and high salt marshes.

The vertical zoning of pyrite framboids, amorphous Fe sulphides and $\mathrm{Fe}$ (III) accumulations as neoformations is related 
to mean high tide level (MHTL). In the lower regions of the intertidal zone, the Fe(III) accumulations started from the surface and in the middle-high and high salt marshes they started below the surface (Kooistra, 1978, 1981). The walls of shrinkage cracks in the sandy intertidal flats usually contained ferric iron accumulations and they were best developed near gullies and the highest parts of the slightly undulating flats. No Fe(III) accumulations were found in the low salt marsh basins where sulphides are found from the surface onwards and MHTL is about equal to surface level. Overall, most Fe(III) accumulations are associated with voids instead of being present in the soil matrix, and are particularly related to faunal channels in the middle-high salt marshes. Summarising, the first metre depth of intertidal and supratidal flats is heterogeneous in the mineralogy of reactive Fe minerals and has its own pedogenetic dynamics.

The micromorphology of sulphides in geological marine sediments has only partly been characterised. Van Rossum (1998) observed framboidal pyrite up to $20 \mu \mathrm{m}$ as well as fine particles up to $30 \mu \mathrm{m}$ in Calais Deposits (nowadays classified as the Wormer Member of the Naaldwijk Formation). This range lies within the lower range as observed for pyrite in recent sediments and described above. RGD (1989) observed the same in a few samples of the Breda Formation, and also framboidal aggregates up to $2.0 \mathrm{~mm}$ long. 0ctahedral and cubical pyrite has been observed more rarely in the Breda Formation. Microframboids around $1 \mu \mathrm{m}$ are found both dispersed and related to carbonate concretions in the Boom Clay; normal framboids of 5-20 $\mu \mathrm{m}$ and large ones up to $100 \mu \mathrm{m}$ have also been observed in the concretions (Baeyens et al., 1985; De Craen et al., 1999b). Additionally, pyrite is also common in the Boom Clay concretions as octahedral crystals up to $8 \mu \mathrm{m}$ and as large $(<500 \mu \mathrm{m})$ octahedral to cubohedral crystals as cement in the septarian fractures. All these observations confirm that framboids remain preserved over long periods (Wilkin et al., 1996).

Microscopic investigation of four glauconite-rich sand samples of the Breda Formation in Zeeland revealed that in addition to pyrite grains, amorphous Fe hydroxide and goethite are present together with secondary Ca carbonate (Schoute et al., 1992). These precipitates cement the primary grains and mostly appear in association with weathered glauconite grains. The samples taken at depths of 25-42 m probably originate from anaerobic conditions and in this context the presence of amorphous Fe hydroxides is remarkable.

5.5.4 Sulphidisation of recent sediments. Sulphidisation and sulphide oxidation in marine sediments and soils were first studied over 150 years ago (Van Bemmelen, 1863). The initial motivation was the forming of acid sulphate soils after reclamation of marine sediments. We will consider two different geographic settings: recent sediments close to the surface where early diagenesis under natural conditions happens and reclaimed marine soils where pedogenic processes happen.
Sulphidisation of marine sediments has been studied for an intertidal flat in the Wadden Sea (Vosjan \& Olanczuk-Neyman, 1977), salt marshes of the Scheldt estuaries (Oenema, 1990a; Zwolsman et al., 1993), 300-400-year-old sediment in the Eastern Scheldt (0enema, 1988) as well as in fine-grained, recent sediments from abandoned channels and mussel culture areas in the Eastern Scheldt (Oenema, 1990b). Vosjan \& OlanczukNeyman (1977) observed $\mathrm{SO}_{4}$ reduction in a sandy intertidal flat and dissolved sulphur concentrations of $100-300 \mu \mathrm{g} \mathrm{S} / \mathrm{g}_{\text {sed }}$ within $25 \mathrm{~cm}$ depth, which is contrary to Kooistra's (1978) findings that pyritisation is negligible in sandy intertidal flats. However, Vosjan \& Olanczuk-Neyman studied only one core.

In the Eastern Scheldt, Oenema (1990b) analysed both sediment and pore water sampled where fresh faeces rich in organic carbon are produced at mussel plots and rapidly accreting channels. He found that at both types of sites sulphidisation of easily extractable $\mathrm{Fe}(\mathrm{III})$ was nearly complete within several tens of centimetres depth. The $\mathrm{SO}_{4}$ reduction rate was also nearidentical, averaging 7-70 $\mathrm{mmol} \mathrm{SO}_{4} /\left(\mathrm{m}^{2}\right.$.day), with the highest rates observed in summer with highest rate of sedimentation and $\mathrm{SO}_{4}$ becoming completely consumed within $40 \mathrm{~cm}$ depth being followed by methanogenesis. The pyrite contents did not vary much with depth, which suggests that Fe monosulphides are produced. The AVS contents varied between 40 and $80 \mu \mathrm{mol}$ $\mathrm{S} / \mathrm{cm}^{3}$, which is somewhat higher than the values found in recent fluvial sediments (Table 14). Note that a dissolved $\mathrm{H}_{2} \mathrm{~S}$ concentration of $1 \mathrm{mmol} / \mathrm{L}$ is equivalent to $2 \mu \mathrm{mol} \mathrm{S} / \mathrm{cm}^{3}$ when porosity is 0.5 . Such an amount is not uncommon in pore water in estuarine supratidal flats (0enema, 1990a) and cannot be ignored when AVS is low. Oenema (1988) also studied early diagenesis in 400-year-old clayey deposits exposed on an intertidal flat. Pyrite content varied between $0.4 \%$ and $1.1 \%$, and organic $\mathrm{C}$ varied between $1.4 \%$ and $2.3 \%$, both invariant with depth within profiles $90 \mathrm{~cm}$ deep. The calculated $\mathrm{SO}_{4}$ reduction rate was about $0.4 \mathrm{mmol} \mathrm{SO}_{4} /\left(\mathrm{m}^{2}\right.$.day) in summer and about 0.1 mmol SO${ }_{4} /\left(\mathrm{m}^{2}\right.$.day) in winter. However, the $\mathrm{CO}_{2}$ produced was stoichiometrically larger than the $\mathrm{SO}_{4}$ decrease, which suggests oxidation of sulphides in the rhizosphere and underestimation of the true $\mathrm{SO}_{4}$ reduction rate. These rates are substantially lower than those within recent marine sediments.

Oenema (1990a) explained the pyrite distributions in vegetated salt marshes and natural levees as the result of the simultaneous occurrence of three processes: (1) sedimentation of pyrite-containing material, (2) pyrite oxidation in the upper rooting zone and (3) pyrite formation at the transition from the suboxic to the anoxic zones in a restricted zone $5-10 \mathrm{~cm}$ thick. The net rate of pyrite formation below the redox transition equals 7-10 mmol $\mathrm{S} /\left(\mathrm{m}^{2} . \mathrm{y}\right)$ in the medium-high marsh. Oenema's electron microscope observations confirmed the more extensive micromorphological observations of Kooistra (1978, 1981). Based on pore water analysis, pyrite oxidation was most intense in the late summer when $\mathrm{SO}_{4}$ at more than double the seawater concentration was observed, Fe concentration was as 
high as $150 \mathrm{mg} / \mathrm{L}$ and $\mathrm{pH}$ as low as 2.7-3.5. Pyrite oxidation is negligible in low salt marshes because of near-permanently wet conditions at the top of the sediment. The degree of pyritisation increased with depth from $<30 \%$ in the oxidised surface layers to $70-80 \%$ in the reducing layers. Some residual oxalateextractable $\mathrm{Fe}$ in these reducing layers seems to be not available; this was also noted by Canavan et al. (2006) for freshwater sediments in Haringvliet (see before). The situation is different for unvegetated marshes. Here, no pyrite is produced but pyrite and AVS depth profiles indicate that Fe monosulphides are produced: the dissolved sulphide concentrations were 10-20 times higher than at the vegetated sites. The difference between these two situations is attributed to lack of production of elemental sulphur, which is needed to convert Fe monosulphide to pyrite, and also to small differences in pore water $\mathrm{pH}$. Zwolsman et al. (1993) confirmed the findings of Oenema (1990a) in broad lines: they found a decrease in $S$ content within a few centimetres' depth (which indicates oxidation of recently deposited pyrite) and below 15 or $40 \mathrm{~cm}$ depth an increase in S content (indicating in situ production of Fe sulphides). Total Fe does not match the characteristic $S$ profiles and sulphide Fe was not analysed separately.

5.5.5 Pyrite oxidation in reclaimed soils. Micromorphologically, pyrite oxidation products in marine soils of droogmakerij polders (polders reclaimed by draining an open body of water such as a lake or shallow part of the sea) have been characterised in detail by Van Dam \& Pons (1972) and Miedema et al. (1973). Air as oxidising reactant enters the clay-rich soil primarily via channels and root holes, which explains some of the appearances of the oxidation products. A distinction needs to be drawn between soils that have excess carbonate and remain neutral, and acid sulphate soils where the amount of Ca carbonate is insufficient to buffer the acid production due to oxidation of pyrite with oxygen. For the carbonate-rich situation, amorphous Fe hydroxides occur along large channels as clusters of spheres that are the same size as the original pyrite framboids or as newly formed accumulations. If pyrite oxidation is incomplete, a nucleus of pyrite is found within the Fe hydroxide sphere. The former are attributed to rapid oxidation in more open conditions and the latter are attributed to slower oxidation in which dissolved $\mathrm{Fe}$ (II) can move away from the pyrite clusters and become oxidised on the walls of a crack. Associated gypsum is mainly formed in root holes and cracks as result of evaporation and supersaturation.

For acid sulphate soils, three stages or zones have been distinguished, with amorphous $\mathrm{Fe}$ hydroxide and jarosite $\left(\mathrm{KFe}(\mathrm{III})_{3}\left(\mathrm{SO}_{4}\right)_{2}(\mathrm{OH})_{6}\right)$ as primary products and goethite and gypsum as minor products. The most important oxidation product in the first stage is amorphous Fe hydroxide: it occurs in the lower part of the oxidised zone. The $\mathrm{pH}$ is not yet acid and Fe hydroxide is more stable than jarosite. It occurs under the same two conditions as in the calcareous soils and also in Fe-impregnated reed remains. Some jarosite may occur as jarosite framboids or newly formed accumulations. In the second stage, jarosite is dominant mainly along large channels and occasionally as framboids. Amorphous Fe hydroxides have been found to occur regularly as accumulations and Fe-impregnated reed remains, in greater amounts than in stage 1 . In this case, the transformation to jarosite is attributed to a slow fall in $\mathrm{pH}$, where $\mathrm{SO}_{4}$ in jarosite still originates from pyrite oxidation and $\mathrm{K}$ is omnipresent in soils. Otherwise, jarosite production under pyrite oxidation is instantaneous when oxygen enters relatively quickly, $\mathrm{pH}$ falls rapidly and jarosite occurs as pseudomorphic spheres. In the third stage and uppermost part of the soil, amorphous Fe hydroxides mainly occur - in even larger amounts than in stage 2. They are mainly present as accumulations and as Fe-impregnated reed remains. Some jarosite has also been observed in similar forms as stage 2, but it was more strongly stained by Fe hydroxides. In this stage, protons have been leached, $\mathrm{pH}$ is higher than in zone 2 and jarosite has been hydrolised to Fe hydroxide. Iron(III) is more mobile under the acidic conditions and Fe hydroxide is formed as accumulations. Some goethite may be formed mainly in this zone, in the largest channels which dry out most during dry periods. It is worth mentioning that under the prevailing acid conditions some clay minerals become unstable and start to hydrolyse. During this weathering process cryptocrystalline silica may be formed.

5.5.6 Glauconite. Glauconite is mineralogically related to the clay minerals but unlike the other clay minerals its origin is primarily autochthonous and not detrital in Dutch sediment. It is therefore discussed separately together with other reactive Fe minerals. Glauconite is diagenetically formed in marine environments; Chafetz \& Reid (2000) realised that it may also form in shallow marine conditions. It gives a characteristic green colour to the sediments (Fig. 14).

The Neogene marine Breda Formation is mostly glauconiterich, having a green or green-black colour: generally, De Mulder et al. (2003) speak of glauconite contents up to $50 \%$, specifically, Schoute et al. (1992) report about $5-20 \%$ volume with average grain size of $84-181 \mu \mathrm{m}$ for just four samples taken from a borehole in the Breda Formation in Zeeland. Based on $\mathrm{K} /$ Ar glauconite dating, Vandenberghe et al. (2014) showed for the Belgian equivalent of the Breda Formation that the highest glauconite contents may be due to in situ production whereas lower contents in younger sediments are due to reworking of these layers and mixing with sediments from the hinterland. Similar patterns are likely for the Dutch Breda Formation and other glauconite-bearing deposits. In three stratigraphical Breda members that occur in South Limburg glauconite is present in small amounts or is absent; the two phosphoritebearing members that occur in the eastern Netherlands are also rich in glauconite (De Mulder et al., 2003). The Pliocene marine 0osterhout Formation is glauconite-poor (albeit that it may be 


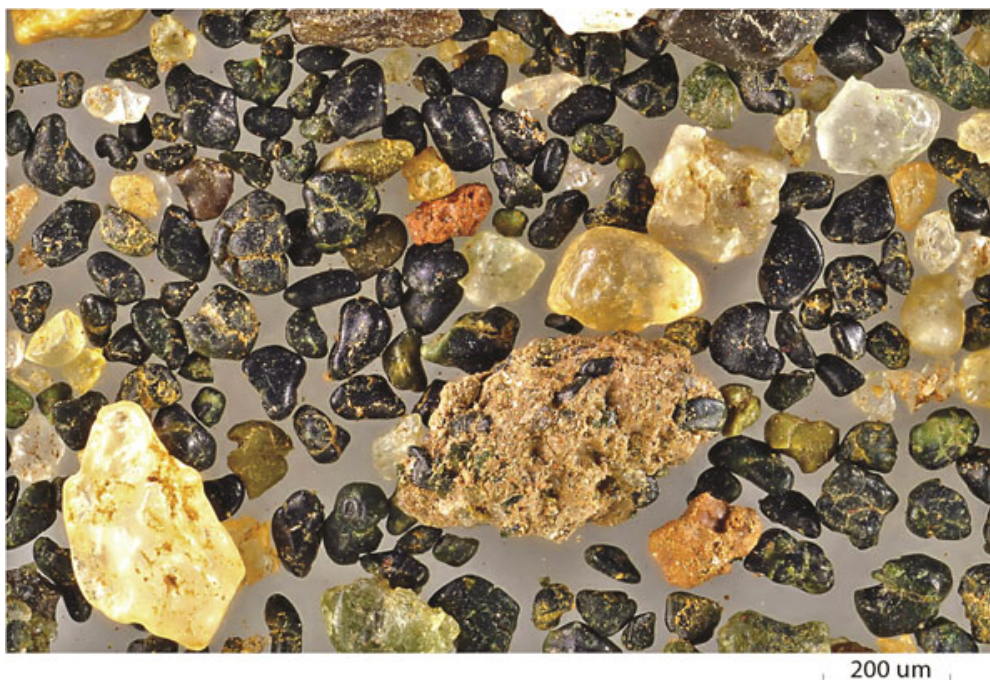

Fig. 14. Example of glauconite-rich sand illustrating the typical occurrence of this mica or clay mineral as sand-sized granules. locally rich in glauconite; www.dinoloket.nl); this and its higher shell content distinguish it from the underlying Breda Formation. The Early Pleistocene marine Maassluis Formation may be locally poor in glauconite. When this is the case, it is difficult to distinguish from the Oosterhout Formation. It is worth pointing out that suspended matter of the Scheldt also contains a little glauconite because of erosion of Neogene/Palaeogene deposits (Wartel, 1977; Baeyens et al., 1998). This is thus detrital glauconite, which suggests that recent sediments from the River Scheldt may contain some glauconite.

The presence of glauconite in marine sand can be chemically recognised by $\mathrm{K}_{2} 0: \mathrm{Al}_{2} \mathrm{O}_{3}$ ratios that are higher than in glauconite-free sand (Huisman \& Kiden, 1998). Unfortunately, more direct analytical evidence for glauconite contents is lacking. Fraters et al. (2006) characterised glauconite-rich samples from the Eocene marine Dongen Formation on reactive Fe. They found $1-3 \%$ reactive Fe in mostly clay sediments, which suggests that glauconite may be part of the reactive Fe as defined earlier. Several studies also reveal that Fe structurally bound in silicates is redox-sensitive too (Fanning et al., 1989; Ernsten et al., 1998; Kostka et al., 1999; Rivaz Perez et al., 2005), i.e. glauconite may be part of the sediment oxidation/reduction capacity.

5.5.7 Fe carbonate. De Craen et al. (1999a,b) and Laenen \& De Craen (2004) described the occurrence of ferroan calcite and siderite, respectively, in carbonate concretions in the Belgian Boom Clay (which is near-equivalent to the Rupel Clay in the Netherlands). For ferroan calcite, two sediment-petrological phenomena were described. First, the concretions themselves showed increasing Fe content from the centre to the rim, with Fe content increasing from $4000 \mathrm{ppm}$ to somewhat more than $6000 \mathrm{ppm}$. The increase in Fe and partly also in Mn reflects a shift towards increasingly reducing conditions during diagenetic growth. Septarian cracks within the concretions were also lined with several generations of fibrous calcite cement. The third and fourth generations were composed of ferroan calcite instead of calcite. The isotopic evolution for $\delta^{13} \mathrm{C}$ and $\delta^{18} 0$ of this cement indicates progressive precipitation from sulphate reduction to methanogenesis. These septarian concretions occur in a series of horizons throughout the Boom Clay.

The second phenomenon is siderite in carbonate concretions from one particular stratigraphical horizon within Boom Clay (or two; De Craen et al., 1999b), where it accounts for on average $15 \%$ of the total carbonate content. The explanation for its genesis is a unique sedimentary sequence, where during a period of slow sedimentation Fe oxides could concentrate in the aerobic zone of the sediment. Subsequently, the high rate of reductive dissolution of these Fe oxides could not be matched by the rate of sulphide production under anaerobic conditions during a period of high sedimentation. As a result, siderite became formed together with framboidal pyrite. Manganese and phosphate are also enriched in this horizon, which further supports the explanation.

\subsection{Solid organic matter}

5.6.1 Organic matter contents and carbon isotopes. Table 26 presents statistical data on organic carbon contents for a variety of marine geological formations in different regions. As expected, the contents are higher in loam and clay than in sand. The contents in sands typically range up to about $2 \%$ and in loam and clay up to $4 \%$ or $5 \%$. The contrast between the Holocene and older formations is not as clear as for the fluvial formations (section 4.6). The organic carbon contents in suspended matter in marine or estuarine environments are higher, with ranges typically from $3 \%$ or $5 \%$ to $10 \%$ or $20 \%$ (Table 16 ). The contents in recent estuarine sediments are several per cent but are lower for recent marine sediments. Suspended matter is thus richest in organic carbon. Wiesner et al. (1990) noted a 
positive correlation between the total organic carbon content of marine sediments in the central North Sea and the weight percentage of the fine fractions (smaller than $20 \mu \mathrm{m}$ ). They noted a 'background' organic carbon content per size class ranging from about $3.4 \%$ for the $<2 \mu \mathrm{m}$ class to about $0.3 \%$ for the 20-63 $\mu \mathrm{m}$ class. Higher contents may occur, which are related to settling of locally produced organic matter and mixing of sediment due to bioturbation or erosion/deposition cycles.

The isotopic behaviour of bulk OM in recent sediment and suspended matter of the North Sea and the estuaries of the Rhine, Scheldt and Ems has been characterised in a series of publications (Salomons \& Mook, 1981; Laane et al., 1990; Dauwe \& Middelburg, 1998; Abril et al., 2002; Middelburg \& Herman, 2007; specifically for the Scheldt also Mariotti et al., 1984; Middelburg \& Nieuwenhuize, 1998; Hellings et al., 1999; De Brabandere et al., 2002; Chen et al., 2005). Organic matter in coastal and estuarine systems may originate from several sources, each of which has a different carbon isotope signature (Middelburg \& Herman, 2007): marine organic matter $\left(\delta^{13} \mathrm{C}\right.$ from -18 to $-22 \%$ ), riverine algae $\left(\delta^{13} \mathrm{C}-30\right.$ to $-40 \%$ ), terrestrial soil organic matter $\left(\delta^{13} \mathrm{C}-26\right.$ to $\left.-27 \%\right)$ and sewage $\left(\delta^{13} \mathrm{C}-14\right.$ to $28 \%$ ).

The isotopic composition of organic carbon in recent coastal marine sediment and suspended matter was studied by Salomons \& Mook (1981), Laane et al. (1990) and Dauwe \& Middelburg (1998). The data show a range in values from $-25 \%$ to $-20 \%$, with the most negative values close to the mouth of the Nieuwe Waterweg and the Scheldt or at the Wadden Sea and an incidental measurement of about $-16 \%$ for suspended or sedimentary organic matter. The most negative values are equivalent to those of organic matter in the Dutch fluvial systems (Table 16). This shows that fractions of continental organic matter are present in the Dutch coastal environment. The ${ }^{14} \mathrm{C}$ values also refer to aged organic matter, where it is interesting to note that the highest ${ }^{14} \mathrm{C}$ value corresponds to the least negative $\delta^{13} \mathrm{C}$ value. The marine-derived organic matter present is thus apparently younger than the organic matter derived from the continent. Chen et al. (2005) report $\delta^{13} \mathrm{C}$ values of -22 to $-21 \%$ for suspended organic matter in front of the mouth of the Scheldt, which indicates a marine origin.

The $\delta^{13} \mathrm{C}$ values of sedimentary $\mathrm{OM}$ in a homogeneous series that also contained several Neogene marine samples averaged $-25.1 \% \pm 1.1$ irrespective of geological formation or depth of burial (Table 16; Hartog et al., 2005). Such values refer to a dominance of terrestrially derived 0M. For comparison, Römkens et al. (1999) found -27.7 to $-25.9 \%$ as $\delta^{13} \mathrm{C}$ values for $0 \mathrm{M}$ in sandy soil samples at a farm in North Brabant. The values were higher with increased contribution of maize and varied with individual grain size class, depth and bulk density. Relatedly, the ${ }^{14} \mathrm{C}$ values were close to $100 \mathrm{PMC}$ for the topsoil, whereas for the subsoil at $60-80 \mathrm{~cm}$ depth they were 74.7 PMC below pasture and 82.4 below maize (Römkens et al., 1998).
Table 27. Characteristics of the recent estuaries related to the Netherlands (derived from Abril et al. (2002)).

\begin{tabular}{llll}
\hline & Rhine & Scheldt & Ems \\
\hline Average discharge $\left(\mathrm{m}^{3} / \mathrm{s}\right)$ & 2200 & 120 & 80 \\
$\begin{array}{l}\text { Salinity at mouth (practical } \\
\quad \text { salinity unit) }\end{array}$ & $7-15$ & $30-32$ & $30-32$ \\
$\begin{array}{l}\text { Volume inner estuary }\left(\mathrm{km}^{2}\right) \\
\text { Residence time of water (days) }\end{array}$ & 70 & 260 & 160 \\
\hline
\end{tabular}

The values also varied with grain size class and bulk density for the two topsoil samples.

5.6.2 Organic matter in estuaries. The physical differences between the three estuaries of Rhine, Ems and Scheldt (see Fig. 1) influence the behaviour of particulate organic matter (Table 27; Abril et al., 2002). The Rhine estuary is a river-dominated estuary, with relatively high river discharges, short residence time, stratified vertical salinity profile and an extended plume at sea. Its inner area is heavily impacted by hydraulic engineering and is strongly reduced in size. The Ems and Scheldt are well-mixed turbid estuaries with small river discharge. The Scheldt has a long residence time and the Ems has an intermediate residence time. The Scheldt is also severely polluted with organic waste, as until recently there were no wastewater treatment facilities in large parts of the catchment. The Scheldt River system can be separated into three parts: (1) the fresh part upstream of Ghent (which is beyond the scope of this review), (2) the Belgian Zeeschelde up to Ghent (57.5-155 km from the mouth at Vlissingen), which is tidal and has increasingly brackish water downstream from Rupelmonde (92 km) and (3) the Dutch Western Scheldt (0-5.7 km), which has saline water. The maximum turbidity zone extends roughly from 90 to $110 \mathrm{~km}$ from the mouth, where the turbidity is highest due to tidal forcing.

A common characteristic of the three estuaries is that the concentration of POC (particulate organic carbon) decreases with salinity, although the maximum values for the Rhine (about $1 \mathrm{mg} / \mathrm{L}$ ) are several factors lower than for the other two. This is mainly due to the Rhine having a more natural decontaminated status in the monitored period at the end of the 1990s. The Rhine estuary has about $5 \%$ organic carbon in its suspended matter for the inland low saline zone (0-20 PSU) and $5-20 \%$ for its high saline zone, which extends out to sea from the coastline, where the highest contents are observed in spring/summer (Abril et al., 2002; Middelburg \& Herman, 2007). The $\delta^{13} \mathrm{C}$ values of suspended organic carbon increase with salinity from $-27 /-26 \%$ to $-24 /-20 \%$, showing an increase in marine signature (Table 16). The $\delta^{13} \mathrm{C}$ results for suspended matter sampled in 1990 are comparable to those for sediment sampled in 1957/58 from the Haringvliet and the Grevelingen before closure by the Delta works. These are all indications of the 
stable nature of POC in the inland part of the Rhine estuary. Algal POC is substantial only in the most saline part.

The suspended matter in the Ems estuary has rather low and constant organic carbon contents (3-5\%), with lowest values at intermediate salinity and a rather flat profile versus salinity for $\delta^{13} \mathrm{C}(-24 \%$ to $-22 \%$ ). Algal POC is only relevant in summer at salinities above 25 PSU. The $\delta^{13} \mathrm{C}$ for its estuarine sediment is somewhat lower, suggesting a more terrestrial origin; the values for the fresh part are even more negative. The Ems estuary is a turbid estuary in which tidal mixing flattens any organic carbon gradient between the fluvial and marine end-members. Abril et al. (2002) deduced that about $50 \%$ of fluvially imported POC, probably from anthropogenic pollution, is mineralised in the estuary.

The situation for the Scheldt is different for the period in the 1990s studied because of the severe pollution with seweragederived material. It is far from representative for the Scheldt system during geological time. Suspended POC in the fluvial stretch is about $18.3 \mathrm{mg} / \mathrm{L}$, decreasing sharply to a few milligrams per litre at salinities of 15 PSU and above. The OC content of suspended matter varies between $3 \%$ and $20 \%$, with the highest percentages found at low salinity and a range between 17 and 27 PSU. The highest percentages are partly attributable to autochthonous organic matter production in spring and summer, as evidenced by the seasonal fluctuation in $\delta^{15} \mathrm{~N}$ values of suspended matter (Mariotti et al., 1984). The $\delta^{13} \mathrm{C}$ values increase near-linearly with salinity, from $-28 /-30 \%$ to $-19 /-$ $23 \%$. Here, a seasonal fluctuation is observed, with most negative values in the fresh stretch of the Zeeschelde, which indicates a contribution of fluvial algae or its detritus (also confirmed by temporal fluctuations in $\delta^{15} \mathrm{~N}$ values). The algal POC is lowest in the maximum turbidity zone, where light penetration is least. A large loss of continental POC thus occurs along the Scheldt estuary, with most mineralisation occurring in the Belgian Zeeschelde. Although the Scheldt estuary is considered to be a well-mixed estuary, its behaviour is intermediate between that of the Rhine and the Ems estuaries. The $\mathrm{OC}$ content has not levelled off at the mouth, which implies that mineralisation of Scheldt-derived POC probably continues under marine conditions. In a single sampling campaign in August, Middelburg \& Nieuwenhuize (1998) found that the sedimentary organic matter differs from suspended organic matter in its $\delta^{13} \mathrm{C}$ and also $\mathrm{C} / \mathrm{N}$ ratio and $\delta^{15} \mathrm{~N}$. Sediment in the upper Zeeschelde had an average $\delta^{13} \mathrm{C}$ of $-26.3 \%$ o \pm 0.5 and the lower Western Scheldt $-23.5 \%$ o \pm 1.0 ; the corresponding values for suspended matter were $-28.9 \%$ o \pm 1.1 and $-20.1 \%$ o \pm 1.7 . Boschker et al. (1999) observed comparable values from $-25.7 \pm 0.8 \%$ to $22.2 \pm 1.1 \%$ depending on whether the flat was vegetated or bare. The sediment thus has a smaller range and appears to be more dominated by soil organic matter, whereas the suspended matter is more a variable mixture of fresh and estuarine algal matter and marine organic matter. Laane et al. (1990) reported a similar average for sediment in the Western Scheldt but a more negative average $(-26.6 \%$ o \pm 2.2$)$ for suspended matter. The algal matter will be less important in autumn and winter, which may more strongly change the isotopic value for suspended organic matter. Rather different values were observed by Boschker et al. (1999) for a flat in the Eastern Scheldt: values around $-20 \%$ irrespective of whether or not the site was vegetated. The difference between the two estuaries was attributed to differences in sedimentation rate and related burial of algal and non-algal organic matter.

5.6.3 Organic matter in the southern North Sea. The organic geochemistry of suspended matter and recent sediments in the North Sea has been studied using various analytical techniques. Boon \& Duineveld (1996) studied near-bottom suspended matter at four stations along the coast from the Netherlands to the Skagerrak, whereas Dauwe \& Middelburg (1998) studied shallow sediments at these four stations as well as two additional ones. Lardinois et al. (1995) studied suspended matter at about 30 sites across the North Sea, including those studied by the former two. Wiesner et al. (1990) studied recent sediments in the central North Sea.

Lardinois et al. (1995) characterised the lipid, protein and chitin contents of suspended organic matter in the North Sea for the winter half year in which no large concentrations of phytoplankton occur. The proteins were by far most abundant, with around $70-85 \%$, the lipids represented $13-26 \%$ and the chitin only $1-3 \%$. As a result, the functional composition of suspended organic matter was very similar to that of phytoplankton, assuming that a stoichiometrically equivalent amount of carbohydrates is present as well. The discrepancy can be attributed to a small contribution of zooplankton, bacterial and terrestrially derived $0 \mathrm{M}$. The functional group analysis is in general harmony with the finding of the carbon isotope analysis that marine-derived organic matter is dominant in marine suspended organic matter.

Wiesner et al. (1990) and Dauwe \& Middelburg (1998) both studied shallow sediments. The former focused on the more stable compounds and the latter on the amino acids as markers for biodegradation. Wiesner et al. found that the fraction of terrigeneous organic carbon in terms of total organic carbon was 68 $\pm 7 \%$ for mud, $83 \pm 13 \%$ for heteroclastic sediment and $84 \pm$ $10 \%$ for sand. This fraction is dominated by vitrinite (the glasslike coalified component of coal) and inertinite (the charred component of coal). Both are derived from the ligno-cellulose components of higher plants (Engel \& Macko, 1993). There is thus a larger fraction of chemically resistant components in the coarse sediments. The alginite and liptodetrinite compounds can also both be substantial. Alganite is the fossilised and coalified product of marine algae and is more strongly restricted to mud. The aliphatic hydrocarbons that were analysed for a small subset of samples point to an admixture of relatively unaltered algal lipids in the fine fraction irrespective of the lithological class of the sample. The general differences between sand and 
clay can be attributed to sand being more exposed to oxygen. Wiesner et al. (1990) attributed the amount and state of organic matter in the sediment to a combination of three factors: (1) the availability of locally produced organic matter, (2) the concentration and size distribution of suspended matter in the overlying water column and (3) the duration of periods of reduced current velocity versus turbulence. Here, a high local primary production may give rise to increased $0 \mathrm{M}$ contents in sand as well as mud, but the difference from the background situation will be more marked for sand.

Dauwe \& Middelburg (1998) determined that amino acids and carbohydrates each composed $8-28 \%$ of the total organic carbon, amino sugars accounted for only about $2 \%$ and the rest remained unidentified. The identified fraction of $0 \mathrm{M}$ was highest for the muddy or silty sediments. The $\delta^{13} \mathrm{C}$ of the organic material in the upper $0.5 \mathrm{~cm}$ had values typical for marine organic matter (Table 16), with slightly more negative values for the deposition areas of the North Sea (Skagerrak and German Bight). The values are somewhat low when compared with the findings of Wiesner et al. (1990), who observed that most organic matter in North Sea sediments is terrigeneous instead of marine. A principal component analysis on the amino acids group showed systematic differences, particularly for neutral protein amino acids and non-protein amino acids, due to selective degradation with an overall quality range from sourcelike material to refractory. The differences were thought to be not only due to in situ degradation but also to degradation prior to deposition. The sandy sediments in the southern North Sea had the freshest organic matter, whereas organic matter in the muddy sediment at the Skagerrak had been degraded most extensively. The non-protein amino acids were highest for the Skagerrak sediment because they had not been incorporated into biota. Note that amino acids occur in various marine and terrestrial organisms and no amino acid is unique to any source (Cowie \& Hedges, 1992). The two amino sugars are relatively resistant to degradation because they are incorporated into structural biopolymer matrices as chitinous material. They were indeed most concentrated in the refractory sediments.

Phytopigments and fatty acids in near-bottom suspended matter were studied by Boon \& Duineveld (1996) for four stations ranging from off the coast of Texel to the Skagerrak, in order to ascertain the effect of resuspension of sediment on the composition of suspended organic matter. The analyses indicated that the geographical differences were more significant than the seasonal variations. Total fatty acids and total chlorophyll-a were strongly correlated, illustrating that the fatty acids were mainly derived from algal material. The station off the coast of Texel showed the freshest, least-degraded suspended organic matter with the fewest terrestrial markers. This station can be considered as part of the southern North Sea, having a coarse sand bottom, shallow depth and limited resuspension due to coarse grain size. At the Skagerrak, the algal part is most degraded. Because resuspension does not play an im- portant role here, due to the Skagerrak's depth, the terrestrial markers were low. The two intermediate stations showed the most complex behaviour: suspended organic matter appeared to be more degraded due to the resuspension of refractory organic matter, which was partly terrigeneous.

5.6.4 Organic matter in Paleogene and Neogene sediments. Hartog et al. $(2004,2005)$ analysed two series of Neogene marine sand samples together with other samples on molecular composition of organic matter, using pyrolysis-GC-MS. The general results are described in section 4.6 and the specific results for the marine Breda and 0osterhout Formations are summarised here. As mentioned earlier, the marine sediment samples contained terrestrially derived $\mathrm{OM}$ and no explicit marine-derived 0M. When compared with the samples from the other sedimentary environments, the Neogene marine sediment samples were rich in phenolic and guaicacyl-lignin derived compounds and poor in fatty acids and branched hydrocarbons. A minor contribution of what was probably dead bacterial biomass was also found. There was also a dominance of guaiacyl units with preserved side-chains, from which it can be inferred that the sediment has remained preserved at an early stage of 0M degradation. Hartog et al. (2004, 2005) therefore concluded that these sediments were apparently deposited with limited oxygen exposure time under stable conditions. The initial presence of marine-derived organic matter and the production of pyrite may have preserved the more recalcitrant terrestrially derived OM.

The organic geochemistry of the Belgian Boom Clay was studied by Deniau et al. (2001, 2004, 2005) for a sample from the underground laboratory in Mol. They focused on the kerogen, i.e. the complex, high-molecular-weight organic matter that is insoluble in non-polar organic solvents, alkali and nonoxidising acids. The kerogen has a high aliphatic nature with a substantial amount of $\mathrm{N}$ and little $\mathrm{S}$. The bulk of the $\mathrm{OM}$ was nanoscopically amorphous without any regular organisation in relation to the clay minerals. The major contribution was from phytoplanktonic material, as evidenced by the presence of, amongst others, degradation products of algal proteins, $n$-alkanols from green algae and medium-chain, evencarbon-numbered fatty acids. This observation is strikingly different from those of Hartog et al. $(2004,2005)$ on Neogene marine sands. Some input of terrestrial and bacterial material was found as, for example, indicated by the presence of long-chain fatty acids and the pyrolysis products of lignin for the Oligocene Boom Clay, and the presence of branched fatty acids, branched hydrocarbons and hopanoid compounds for the Neogene marine sands. As a result, the organic matter in the clay samples is rather immature, with a major role for degradation-recondensation in the formation of the kerogen. Selective preservation, mineral-sorptive protection and natural sulphurisation must have played a minor role. 


\section{Other sediments}

Sediments other than marine or fluvial are present in the subsurface of the Netherlands as well (cf. Fig. 3). Glacial deposits originating from the two glaciations that reached the Netherlands are present in the north of the country. There are also recent and geological lacustrine sediments. The mineralogy of the recent sediment and suspended matter in the large lakes that are associated with the surface water systems of the big rivers were discussed in section 4 . Here, we will focus on the remaining types of lacustrine sediments. We will discuss various kinds of aeolian sediments important in the Netherlands: cover sand, loess and coastal dunes. The first two were deposited during the last glaciation. The coastal dunes are Holocene in origin and are active in terms of erosion and accumulation, although their morphodynamics are nowadays managed. Aeolian drift sands are also present in the Netherlands but we are not aware of any mineralogical studies of them. We will discuss peat and bog ore, even though these are not sediments. Peat is an important geomaterial in the Dutch subsurface, especially close to or at the surface. Bog ore (synonymous with bog iron ore) is a special local phenomenon that has been well studied.

\subsection{Glacial deposits}

Two lithostratigraphical formations with glacial deposits are discerned in the Netherlands: the Peelo Formation from the Elsterian age and the Drente Formation from Saalian. Two wellknown deposits in the northern part of the country are the Potklei (Nieuwolda Member) from the first and glacial till or boulder clay ('keileem'; Gieten Member) from the second. Potklei is actually a glaciolacustrine to marine infilling of subglacial tunnel valleys and is often varved. The boulder clay was deposited as a till during the Saalian glaciation and regionally forms a less than 1-40 m thick layer in the northern and eastern provinces. The glacial sediments have been studied less intensively on their mineralogy than the fluvial and marine sediments. For the Peelo Formation, the clay mineralogy was characterised on the clay fraction of one sandy, aquifer sample (Breeuwsma \& Zwijnen 1984) and on three clay samples from the Potklei (Breeuwsma et al., 1987). The findings for the sand-derived sample differ somewhat from those for the clay samples. Illite is the dominant clay mineral (30-50\%), kaolinite (5-30\%) and smectite (10-50\%) are also important but are more important in the clay samples than in the sand sample, chlorite is low $(<5-10 \%)$ and no vermiculite or illite chlorite were detected. Glauconite may be found as accessory mineral in both glacial formations, where it occurs locally within the Uitdam Member of the Drente Formation (www.dinoloket.nl). This is the result of the reworking of older marine deposits. Similarly, Pleistocene glacial sediments may contain radiolaria or diatoms from reworked Tertiary sediments (Anderson, 1970;
P. Vos, pers. comm.). This makes Crommelin's (1945) single observation that Potklei contains amounts of diatoms below the detection limit not representative (Table 25; Crommelin, 1945), although it will generally hold that glacial sediments contain few diatoms.

The boulder clay is poorly sorted, compact and contains stones and boulders as rock fragments, in addition to grains of individual minerals (De Mulder et al., 2003). All kinds of rock fragments can be present: granite, metamorphic, sandstone, limestone (including dolomite) and flint. Two major types of boulder clay were initially distinguished (De Waard, 1949; Zandstra, 1971, 1983): (1) grey or common type boulder clay with an average carbonate content of about $7 \%$ in the matrix when unweathered, a high flint content, hardly any limestone and a predominance of crystalline rocks of central Scandinavian provenance, and (2) red boulder clay, occurring as masses on and in the grey type, with an average carbonate content of about $24 \%$ when unweathered, considerable limestone, little flint and crystalline components of eastern Scandinavian provenance. The distinction by colour is classically made by geologists, where it must be realised that secondary chemical processes may also change the colour. Later on, as many as 11 types of boulder clay were distinguished (Zandstra, 1974). The mutual differences are explained as a difference in ice flows and provenance, rather than by pedogenesis or diagenesis.

Heavy mineral contents indicate the presence of a garnetepidote in the grey boulder clay and a hornblende-garnet association in the red boulder clay. Riezebos (1968), who characterised individual grain size classes mineralogically, showed that the frequencies of the minerals are influenced by the grain size class. His results indicate that it is impossible to predict which fractions to analyse to obtain the most reliable information. Remarkably, when compared with other Dutch sediments studied, the percentage of heavy minerals in the isolated sand fraction has been determined many times for boulder clay. It is usually $0.2-0.5$ in the $125-250$ or $40-500 \mu \mathrm{m}$ fraction, and in only two red boulder clay samples it was 1.0\% (De Waard, 1949; Rappol, 1984, 1986). The latter percentage is high for Dutch sediments (Druif, 1927).

Both De Waard (1949) and Riezebos (1968) found that the red boulder clay (also referred to a Voorst type) is less rich in quartz and more abundant in feldspars and rock fragments. The feldspars are mainly found in the size class below $150 \mu \mathrm{m}$ and the rock fragments in the size class above $75 \mu \mathrm{m}$ (note that grains up to $420 \mu \mathrm{m}$ were mineralogically investigated). Based on small sample series, Druif (1927), Van Baren (1934) and De Waard (1949) found that the dominant feldspar minerals are orthoclase and/or albite. With respect to feldspars, these glacial sediments are thus more similar to fluvial deposits of Rhine origin than of Eridanos origin (cf. Table 4). Tills may contain considerable amounts of local, preglacial sediments, even occurring as lenses within the till (Rappol, 1984, 1986). Micas are also observed, especially in the size class below 
$16 \mu \mathrm{m}$, where more weathered mica is found in the grey boulder clay than the red boulder clay. The opaque minerals have been found to be dominated by oxides and not pyrite. The amounts of ilmenite, leucoxene and rutile were above $10 \%$ of the total amount of grains; magnetite, haematite and also goethite and chromite in the red boulder clay each contributed between $2 \%$ and 10\%. Druif (1927) observed ilmenite and magnetite as important heavy minerals in all samples and biotite, glauconite and apatite in only a few samples or in only one sample. The identification of biotite is particularly interesting because biotite and mica are both phyllosilicates but biotite weathers considerably faster.

Klein \& Griffioen $(2010,2012)$ evaluated carbonate analyses of samples from the Drente and Peelo Formations. They concluded that the Drente Formation as a whole is mostly calcareous, and in the Peelo Formation the sand is mostly poor in carbonate and the clay is rich in carbonate (Tables 9 and 28). Van der Marel (1950) concluded that calcite is negligible or absent in the clay fraction $(<2 \mu \mathrm{m})$ of soils developed on glacial till or Potklei and that dolomite, siderite and magnesite are not present. This suggests that carbonate is mainly present in the silt fraction, as is the case for fluvial sediments (see section 4.4). Hartog et al. (2005) analysed the isotopic composition of carbonate in two samples from the Drente Formation in eastern Netherlands and found values close to $0 \%$ for both $\delta^{13} \mathrm{C}$ and $\delta^{18} 0$. This implies an allogenic marine origin instead of a syngenetic origin, attributable to reworking of marine sediments from the 0osterhout or Breda Formations or erosion of Fenno-Scandinavian limestone and subsequent glacial transport. The carbonate status of glacial till has received attention in the past, albeit mostly qualitatively, in order to distinguish between the different types of till. As mentioned earlier, the Voorst-type orred boulder clay has an average carbonate content of about $24 \%$ in the matrix when unweathered (De Waard, 1949; Rappol, 1986). It then also contains 30-60\% limestone as rock fragments (De Waard, 1949; Zandstra, 1967; Rappol, 1986), which has an East Sea provenance. Other unweathered boulder clay types contain $2-12 \%$ carbonate in the matrix and 10-40\% limestone and chalk rock fragments (Rappol, 1986). As is the case for marine sediments (see section 5.4.1), the carbonate content is highest in the silt fraction, lowest in the fine- to medium-grained sand fraction and higher again in the coarser sand fraction (Rappol, 1983). The boulder clay is frequently decalcified after deposition and the depth of decalcification depends on the local hydrogeological conditions (De Waard, 1949; Rappol, 1984, 1986). The evidence for decalcification is the similar amount of flint fragments (i.e. similar provenance) in non-calcareous and calcareous boulder clay within individual profiles (De Waard, 1949; Zandstra, 1967).

Klein \& Griffioen (2012) also present data for pyrite, reactive Fe other than pyrite and organic matter (Table 28): the Drente Formation generally has negligible amounts of pyrite but amounts above $0.1 \%$ pyrite can be found and amounts above
$1 \%$ are rare. Sand of the Peelo Formation is generally poor in pyrite, but amounts between $0.1 \%$ and $1 \%$ are also found; clay and loam frequently contain pyrite, the average contents being $0.8 \%$. In both formations, the non-pyritic reactive Fe accounts for around $0.5 \%$ in all lithological classes. The contrast in sediment Fe chemistry thus seems restricted to that of pyrite. The pattern for organic matter mirrors that of pyrite: low contents in the Drente sediments and sand of the Peelo, and higher contents in its clay and to a minor extent in its loam.

The $\delta^{13} \mathrm{C}$ values of sedimentary $\mathrm{OM}$ in a uniform series of 28 samples that also contained several glacial sediments from the Drente Formation was on average $-25.1 \%$ o \pm 1.1 irrespective of geological formation or depth of burial (Table 16; Hartog et al., 2005). Such values testify to a dominance of terrestrially derived OM (see section 5.6). Two samples from the Drente Formation were analysed on molecular composition of organic matter using pyrolysis-GC-MS together with samples from other origins (Hartog et al., 2004, 2005) and the general results are described in section 4.6. When compared with the samples from the other sedimentary environments, the Drente samples were dominated by lignin-derived markers, had a higher degree of side-chain oxidation of hopanoids and lignin derivatives, and contained more macromolecular OM than low-molecularweight compounds. This indicates that the $0 \mathrm{M}$ has undergone severe aerobic degradation, as was discussed more extensively in section 5.6. Glacial deposits such as the Drente Formation often contain reworked sediments, and Hartog et al. (2004) suggested that reworking increases the oxygen exposure time, which affects the reactivity of its sedimentary $0 \mathrm{M}$.

Gravel- to sand-sized nodules containing vivianite were observed by Riezebos \& Rappol (1987) in Saalian till in Twente, East Netherlands. The nodules were $2-5 \mathrm{~mm}$ in diameter and were associated with sedimentary rock fragments of similar size containing glauconite and phosphorites. Vivianite is also associated with carbonates in these rock fragments. The till layer was found on top of the Oligocene marine Rupel Formation. Thin-section studies suggested that the nodules are authigenic (Riezebos \& Rappol, 1987). A primary control in the occurrence of such nodules seems to be the presence of phosphate-rich sediments that have been glacially eroded: the probable mechanism is diagenetic conversion of Ca phosphates into vivianite. This mineral can be found in the eastern part of the Netherlands, where Tertiary marine sediments lie close to the surface and are known to contain phosphorite nodules (Laban, 1988).

\subsection{Lacustrine deposits}

No geological formations predominantly composed of lacustrine deposits occur in the Netherlands. Lacustrine deposits are found in the Echteld Formation and also in the Boxtel (as Tilligte Member), Peelo (Potklei as Nieuwolda Member) and Drente (as Uitdam Member) Formations, where they were formed under periglacial conditions (De Mulder et al., 2003). However, we 
Table 28. Regional characteristics (as percentiles) of the pyrite, reactive Fe, organic matter and Ca carbonate contents (in wt\%) in the two Dutch glacial formations on the Central Drenthe Plateau (derived from Klein \& Griffioen (2012)).

\begin{tabular}{|c|c|c|c|c|}
\hline Glacial formation & Lithology class & Samples & Median & 82.5 percentile \\
\hline \multicolumn{5}{|c|}{ Pyrite } \\
\hline Drente & All & 67 & 0.1 & 0.1 \\
\hline Peelo & Sand & 134 & 0.1 & 0.1 \\
\hline Peelo & Loam & 19 & 1 & 1.6 \\
\hline Peelo & Clay & 43 & 0.7 & 1.5 \\
\hline \multicolumn{5}{|c|}{ Organic matter } \\
\hline Drente & Sand & 22 & 0.3 & 0.6 \\
\hline Drente & Clay & 33 & 0.3 & 0.6 \\
\hline Peelo & Sand & 171 & 0.4 & 0.6 \\
\hline Peelo & Loam & 17 & 1.2 & 2.6 \\
\hline Peelo & Clay & 37 & 2.8 & 6.7 \\
\hline \multicolumn{5}{|c|}{ Reactive Fe } \\
\hline Drente & Sand & 22 & 0.2 & 0.6 \\
\hline Drente & Clay & 35 & 0.2 & 0.5 \\
\hline Peelo & Sand & 129 & 0.1 & 0.2 \\
\hline Peelo & Loam & 18 & 0.2 & 0.3 \\
\hline Peelo & Clay & 41 & 0.2 & 0.4 \\
\hline \multicolumn{5}{|c|}{ Ca carbonate } \\
\hline Drente & Sand & 25 & 0.3 & 0.8 \\
\hline Drente & Clay & 38 & 0.6 & 2.7 \\
\hline Peelo & Sand & 172 & 0.2 & 0.4 \\
\hline Peelo & Clay & 40 & 2.2 & 6.1 \\
\hline
\end{tabular}

know of no studies that have addressed these periglacial deposits individually. Here, we will discuss lacustrine sediments found in small isolated lakes and fens or buried in the glacially excavated Amsterdam basin and of Middle Pleistocene origin.

Marnette et al. (1993) studied the S chemistry of two moorland pools in the Veluwe, looking especially at the Fe sulphides and organic S; Feijtel et al. (1989) studied one of these two pools. As the pools had been strongly affected by acid deposition and enhanced atmospheric $S$ input in the preceding few decades, the results cannot be considered to be representative for natural conditions and local lacustrine sediments under buried conditions. However, the data can be compared with findings for recent sediments within the Rhine-Meuse river system. The acid volatile sulphide content ranged from 22 to 288 $\mu \mathrm{mol} / \mathrm{g}$ and the pyrite-S content from 480 to $8000 \mu \mathrm{g} / \mathrm{g}$. This is lower than the contents found in recent sediments along the large rivers (Table 14). Micromorphologically, pyrite was found as framboids varying in size from 15 to $25 \mu \mathrm{m}$ associated with organic matter and as tiny single crystals not necessarily associated with organic matter. The slow formation of framboidal pyrite in microniches associated with organic matter particles is assumed to be the pathway of pyrite formation, where pure $S$ is available for the sulphurisation of precursor FeS to pyrite within microniches. The presence of single crystals indicates that some pyrite may also form rapidly. The explanation for the general association of pyrite with organic matter microniches is preferential oxidation of pyrite at locations where pyrite is not protected against $\mathrm{O}_{2}$ intrusion. The organic-bound $\mathrm{S}$ constituted $70 \%$ of total sedimentary $S$ in the upper $2 \mathrm{~cm}$ of the sediment and $50 \%$ in the next $8 \mathrm{~cm}$; the organic matter content was about $6 \%$ throughout the profile. These data indicate that the occurrence of organic $S$ cannot be neglected.

The speciation of $S$ in these moorland pools is strikingly different from that in Lake Vechten (Table 14; Hordijk et al., 1989), which is an isolated sand pit lake and was also subject to enhanced atmospheric $S$ input before being studied. AVS amounted to $60 \%$ of total $S$ whereas pyrite-S was less than $10 \%$, organic $S$ was $10-30 \%$ and elemental $S$ was negligible at $3 \%$. The conditions for pyrite forming were apparently unfavourable, which Hordijk et al. (1989) attributed to high turnover of organic carbon and/or complete absence of oxygen in these recent sediments.

Calcareous gyttja deposits are found as lacustrine deposits in local depressions left after an ice age, for example as infill of a pingo (Hoek et al., 1999) or infillings of oxbow lakes (the latter are part of the Echteld Formation; Smittenberg et al., 1998; Tebbens et al., 2000). The isotopic composition of these carbonates varied during deposition, depending on the climate and the influx of groundwater. Hoek et al. (1999) measured $\delta^{13} \mathrm{C}$ values from $-8 \%$ o to $+1 \%$ and $\delta^{18} 0$ values from $-7 \%$ o to 
$-3 \%$ for a continuous gyttja layer of $2 \mathrm{~m}$ thickness formed in a local depression (cf. Table 11). The lowest values are associated with colder conditions during the Early Holocene. The isotopic composition of such authigenic carbonates is thus variable and it is difficult to generalise from them. Unfortunately, the abovementioned authors did not study the presence or absence of siderite in addition to that of calcite resulting from the groundwater influx.

Lacustrine sediments are also found in the Amsterdam basin, a glacially excavated basin left after the retreat of the Saalian ice sheet. The Amersfoort basin is another related major basin that accommodated a lake (De Gans et al., 2000). The isotopic composition of carbonate $(0, \mathrm{C}, \mathrm{Sr})$ and several other aspects of sediments have been studied in detail in three cores from Amsterdam (Beets \& Beets, 2003; Beets et al., 2006). Three types of lacustrine sediments were found: (1) Late Saalian lake sediments deposited under variable inflow of Rhine water, (2) Late Saalian shallow pool sediments and (3) Eemian lake sediments. The amount and isotopic composition of carbonate differs between these three types (Table 11). The differences in isotopic composition are mainly the result of whether or not there was inflow of river Rhine water, the evaporative concentration in the pools and the climate. The carbonates are authigenic, as evidenced by the $\mathrm{Sr}$ content being lower than the marine carbonate content and the strong covariation between $\delta^{18} 0$ and $\delta^{13} \mathrm{C}$ and between organic carbon content and $\delta^{13} \mathrm{C}$ of carbonate. The Eemian lake sediments comprise a layer $1 \mathrm{~m}$ thick and contain far more calcareous diatoms and have a higher $\mathrm{S}$ content due to some brackish conditions. The presence of authigenic siderite in distinct, somewhat permeable layers in the pool sediments was inferred from the high Fe contents ( $>2000-$ $3000 \mathrm{ppm}$ ) and rapid colouring of the sediment from ochre to brownish-red after exposure to air.

\subsection{Aeolian deposits: loess}

Loess deposits are composed of loam and stratigraphically classified as the Schimmert Member, being part of the Boxtel Formation. They are found at the surface in southern Limburg and on the southeastern border of the Veluwe. Buried and usually reworked loess deposits are also increasingly being recognised in other parts of the Netherlands (Schokker, 2003). The heavy mineral composition of the loess in southern Limburg is entirely different from that of the underlying formations and the recent deposits of the Meuse river. It is more analogous to the Edelman's (1933) A group (section 4.1.1). Table 29 gives the standard heavy mineral contents of loess from southern Limburg and the Veluwe area (Mücher, 1973). Mücher (1973) also noted that the heavy opaque minerals make up around $25 \%$ of the total heavy mineral fraction. Vink (1949) pointed out that zircon and rutile are relatively more important as heavy minerals in loess, Brabant loam (as Liempde Member of the Boxtel Formation) and fine cover sands than in coarser sands. The pre- ponderance of zircon and rutile in loess was also observed by Edelman (1933) and must be attributed to a grain-size effect, as zircon and rutile are usually more fine-grained. According to Druif (1927), the heavy mineral content in the sand fraction of loess varies around $1 \%$.

It is widely recognised that loess deposits have variable carbonate contents, largely due to carbonate leaching, and there is debate about whether decalcification was active prior to the present landscape conditions (Slager et al., 1978). Calcite is found in the clay fraction of loess soils, together with small amounts of dolomite (Van der Marel, 1950). The ratio of acetic acid soluble carbonate to $\mathrm{HCl}$ soluble carbonate is $0.88-0.95$ for the clay fraction and around 0.7 for the soil as a whole. This suggests that the percentage of dolomite is systematically lower in the clay fraction than in the coarser fraction. Van Baren (1916) studied the relationship between carbonate content and grain size class for deeper loess deposits. He found three layers several metres thick in a quarry: the upper layer was carbonate-free, the second layer contained $6-13 \% \mathrm{CaCO}_{3}$ and the third layer an average of $1.5 \% \mathrm{CaCO}_{3}$. Most of the $\mathrm{CaCO}_{3}$ was associated with the small particle classes, as the content decreased from $16 \%$ for the $<10 \mu \mathrm{m}$ class to $6 \%$ for the $100-200 \mu \mathrm{m}$ class for samples from the second layer. This is broadly similar to the Holocene fluvial sediments of the Rhine (see section 4.4.1). Reinhold (1925) and Erdbrink (1953) reported that Ca carbonate can also occur as coatings on quartz grains, which suggests secondary precipitation of carbonate. Slager et al. (1978) also mentioned the occurrence of small amounts of secondary Ca carbonate as channel neocalcitans and nodules. Finally, the occurrence of lössmannetjes (or Lösskindl in German: loess children) is reported in South Limburg and along the Rhine. These are secondary carbonate concretions varying in size from a pea to a human foot (Van Schermbeek, 1889; Algemeen Handelsblad, 1923). Van Baren (1916) mentioned that these concretions contain 43-51\% Ca carbonate and Mücher (1973) mentioned that they are particularly found immediately under the boundary between the calcareous and carbonate-free loess.

Reinhold (1925) noted that when the carbonate content is left out, the amount of $\mathrm{Al}_{2} \mathrm{O}_{3}$ and $\mathrm{Fe}_{2} \mathrm{O}_{3}$ in loess is fairly constant, around $15 \%$. This amount includes the silicates and oxyhydroxides. Mineralogical analysis by Druif (1927) revealed that ilmenite and magnetite are prominent Fe oxides. Orthoclase is always present, but microcline and plagioclase vary from not observed to normally present. Muscovite is also frequently observed but biotite is not. The amount of heavy minerals in the sand fraction is also relatively high, 0.4 to $1.3 \%$. The clay fraction is dominated by illite, according to Mücher (1973). The kandite fraction (kaolinite group) is less than $10 \%$ and the smectite fraction is less than $15 \%$. The smectite fraction seems to be somewhat higher in the calcareous loess than in the noncalcareous loess and it increases westward from Sittard. Quartz is also a significant constituent of the clay fraction, with contents $10-15 \%$. 
Table 29. Typical heavy mineral assemblages (in counts of 100) of the aeolian loess deposits (derived from Mucher (1973)).

\begin{tabular}{lllllllllll}
\hline Region & Garnet & Hornblende & Epidote & Saussurite & Staurolite & Augite & Tourmaline & Metamorphic & Zircon & Rutile \\
\hline & & & & & & & & & & \\
Limburg & 14 & 4 & 21 & 0 & 1 & 0 & 1 & 1 & 39 & 17 \\
Veluwe & 11 & 7 & 32 & 1 & 3 & 0 & 1 & 1 & 28 & 16 \\
\hline
\end{tabular}

Klein \& Griffioen (2008) statistically characterised reworked loess deposits (part of the Boxtel Formation) in the Roer Valley Graben. Both sand and loam samples were classified in this sedimentary facies. Twenty per cent of the loam samples contained between 0.1 and $0.5 \%$ pyrite; most of the loam samples and the sand samples contained an amount below the detection limit of $0.1 \%$. This implies that the burial of loess deposits may cause authigenic production of pyrite in a Pleistocene groundwater environment. The carbonate content was around $0.5 \%$ for the loam and from below $0.2 \%$ to $1 \%$ for the sand. Sedimentary organic matter content was generally below $1 \%$ for both classes and incidentally up to $5 \%$. It was not indicated whether or not the pyrite was associated with the high sedimentary organic matter content.

A noteworthy phenomenon in the loess of southern Limburg is the presence of a volcanic tuff layer associated with the Eltville Tephra, which is related to Quaternary Eifel volcanism (Meijs et al., 1983; Pouclet \& Juvigne, 2009). The layer has been identified as a dark grey layer varying in thickness from millimetres to centimetres in the yellowish loess. Its age is close to 20,000 years and the grain size distribution resembles that of loess. The volcanic deposits are often intermingled with calcareous loess deposits. The layer is composed of pyroclasts and volcanic glass that has altered to an illite-type of clay. The heavy mineral fraction comprises clinopyroxenes (40$60 \%$ ), olivines (22-50\%), brown amphiboles (3-13\%), apatite $(<9 \%)$, some titanite and traces of phlogophite, prehnite and haüyne. Biotite, $\propto$-tridimite and nepheline are found as light minerals as well as feldspars, which are difficult to separate from loess feldspars. Tephra layers have also been detected in a peat and gyttja-rich infill of a Dutch pingo remnant (Davies et al., 2005) and lacustrine deposits in a small lake in the floodplain of the Meuse river (Cremer et al., 2010). This tephra material was identified from the occurrence of volcanic glass shards. Such layers may be related to the Laki eruption on Iceland in AD 1783. Further, pumice granules have been observed in fluvial sands of an upper subunit of the Kreftenheije Formation, associated with the 12.9 BP Laacher See volcano eruption (Busschers et al., 2007).

\subsection{Aeolian deposits: dune sand}

Holocene dune sand is found along the coast of the North Sea and is geologically classified as the Schoorl Member as well as part of the Zandvoort Member, both of which belong to the
Naaldwijk Formation. Two main types of dune sand (and also related beach sand) are distinguished, largely on the basis of their heavy mineral association (Baak, 1936; Eisma, 1968): one type occurs north of Bergen and the other type south of Bakkum, with a transitional zone in between. They were described briefly in section 5.1. An identical geographical separation is found for the feldspar, $\mathrm{Al}$ and $\mathrm{Ca}$ carbonate contents, with $\mathrm{Al}$ being proportional to the feldspar content in these sands (Eisma, 1968). The feldspar content in dune sand is $6-8 \%$ north of Bergen and $13-17 \%$ south of Bakkum and intermediate in between; the feldspar content increases towards the finer sand fraction. In a dune sand sample, Druif (1927) optically observed apatite, muscovite, no biotite and all three feldspars; the latter as expected in decreasing amounts in the sequence orthoclase-microklineplagioclase.

The dune sands north of Bergen usually contain less than $0.5 \% \mathrm{CaCO}_{3}$, with the foredune having a slightly higher content than the dunes farther inland. The carbonate content is high in dune sand south of Egmond and may increase to more than $25 \%$ through sorting. This is due to selective erosion of the finer grains and resulting accumulation of coarse shell fragments. For dune slacks (the valleys or troughs between dunes) on the Wadden islands, Sival (1997) found that the $\mathrm{CaCO}_{3}$ generally ranged between 0 and $2 \%$ with outliers up to $25 \%$ for both topsoil and subsoil samples. This is different from the two dune types described earlier, but dune slacks are also geomorphologically a specific subunit of dunes. Rozema et al. (1985) investigated decalcification in the coastal dunes of North Holland and Schiermonnikoog based on historical analyses and assuming first-order decalcification with respect to carbonate content. They concluded that decalcification and associated acidification of the topsoil from a $\mathrm{pH}$ of 8 to a $\mathrm{pH}$ of 4-6 may occur within a time span of several hundreds of years for a layer of $10 \mathrm{~cm}$. Using a similar approach, Stuyfzand (1993) calculated a rate that is about 10 times faster. Van der Sleen (1912) previously mentioned that the older, inner coastal dunes have been dolomitised due to rain water leaching based on much lower $\mathrm{CaCO}_{3}$ to $\mathrm{MgCO}_{3}$ ratios at near-similar $\mathrm{MgCO}_{3}$ contents for these sands than for younger, more seaward dune sands.

Enrichment of carbonate may also be observed in the topsoil of dune slacks. Sival et al. (1998) studied this phenomenon at three slacks, where all three are former beach plains and nowadays separated from the beach by an embankment or low dunes. Periodic flooding with seawater and aeolian transport were the mechanisms responsible for the enrichment with 
carbonate shells or fragments and with micrite and silt-sized carbonate particles found in the topsoil. However, authigenic carbonate in the form of nodules, calcitans and crusts was also observed. These were probably formed due to $\mathrm{CO}_{2}$ degassing in association with (1) the capillary rise and evaporation of calcareous groundwater and (2) seepage of carbonate-saturated groundwater and related inundation of the slack.

Stuyfzand et al. (2010) made a comparison on carbonate content and grain size distribution (and other elemental contents) between natural dune sand and man-made sand suppletions at six locations from Wassenaar to Texel. They found that the carbonate content in suppleted dune sand was significantly lower at Wassenaar (where carbonate-rich natural dunes are found) and significantly higher at the other five locations (where carbonate-poor dunes are found). Suppleted sand is also generally coarser, with lower contents of clay and silt. Stuyfzand et al. (2010) also observed higher contents of $\mathrm{Ca}, \mathrm{Na}, \mathrm{K}, \mathrm{Fe}$ and $\mathrm{Ti}$ in dune sand at Wassenaar than at Bergen and the four more northern locations. This indicates less quartz and more mineralogical richness, probably including feldspars, micas and heavy minerals. Comparably, Van der Sleen (1912) states that the $\mathrm{Fe}$ and $\mathrm{Mg}$ contents are highest in between Egmond and Wassenaar, intermediate south of Wassenaar and lowest north of Egmond.

\subsection{Aeolian deposits: cover sand}

Cover sands are widely found in the Netherlands either at or close to the surface in the Pleistocene part of the Netherlands or buried below Holocene deposits in the Holocene part. Except for the highest areas (ice-pushed ridges), cover sands were deposited under periglacial conditions in a continuous belt north of the loess belt. They are geologically classified as the Wierden Member, which is part of the Boxtel Formation. When lying at the surface, they are subject to pedogenesis, which in recent decades has been enhanced by acid rain. Here, we will focus on the subsoil (>50 cm depth) and buried sediments.

With the exception of the heavy mineral contents, the mineralogy of these cover sands has been poorly studied; more studies have been done on their geochemistry. The lithological composition of the younger cover sands changes from place to place. Crommelin (1964) investigated the content and composition of the heavy mineral associations of cover sands in different parts of the Netherlands. Only the 150-210 $\mu \mathrm{m}$ fraction was considered in order to minimise the grain size effects. The differences in the heavy mineral composition of the preWeichselian formations in the northern, central and southern parts of the country are reflected in the heavy mineral composition of the superimposed cover sands. Mineralogically, the cover sands may be subdivided into (1) a northern region where garnet, tourmaline and metamorphic minerals are conspicuous, (2) a central region where these three components show lower values but where epidote-saussurite and hornblende-pyroxene groups are more important and (3) a southern region with high percentages of tourmaline and metamorphic minerals.

Van Grinsven et al. (1992) microscopically observed that a series of subsoil samples of acid sandy soils below forest (which are probably cover sands) contained about $10 \%$ of predominantly K-feldspar. Nelson \& Niggli (1950) isolated opaque grains from a cover sand sample in North Brabant and performed XRD analysis. They found rutile and little ilmenite. Moura \& Kroonenberg (1990) deduced from the low $\mathrm{Rb}$ content of Nuenen aeolian sands (which are nowadays classified under the Boxtel Formation) that contrary to fluvial and marine sands, these sands are virtually free of micas. Mol (2002) geochemically characterised subsoil and topsoil samples below forest in the Pleistocene part of the Netherlands. It is probable that many or all of these samples are cover sands from the Boxtel Formation. Mol distinguished five regions and applied cluster analysis to the dataset. Subsoil samples from eastern North Brabant and the northern parts of the Veluwe and the Utrechtse Heuvelrug lay in one cluster. Those from the southern parts and eastern Gelderland lay in another cluster, whereas those from the northern part of the Pleistocene area of the Netherlands lay in all four clusters. The contents of $\mathrm{Na}_{2} \mathrm{O}, \mathrm{K}_{2} \mathrm{O}, \mathrm{CaO}, \mathrm{MgO}, \mathrm{Fe}_{2} \mathrm{O}_{3}$ and $\mathrm{TiO}_{2}$ were generally a factor 1.5-2 higher in the second cluster than in the first cluster, which indicates regional differences in mineralogical richness. In the second cluster, the Na-feldspar content was 5.2 $\mathrm{wt} \%$ and the K-feldspar content was $6.6 \mathrm{wt} \%$. Schokker et al. (2005) considered the abundance of Na-feldspars in fine-grained aeolian deposits and related small-scale fluvial and organic deposits as revealed by geochemical analysis of samples from five sediment cores across the Roer Valley Graben. The Na-feldspar content amounted to $9 \%$, coinciding with fine sand or loam.

Klein \& Griffioen (2008) characterised a small set of reworked cover sand samples from the Roer Valley Graben. As expected, the pyrite and carbonate contents were mostly below detection limit, but reactive iron ranged up to $0.5 \%$ and organic matter was relatively high: $0.5-12 \%$ in $40 \%$ of the samples. Further, Klein \& Griffioen (2012) characterised sand samples from the Boxtel Formation at the Drenthe Plateau and below Holocene deposits in the northern Netherlands. An interesting conclusion is that burial leads to slightly, but statistically significantly, higher pyrite contents, but not to significantly different carbonate contents. Diagenesis during the Holocene resulted in an average pyrite content of $0.2 \%$ for the buried samples but the content was below detection limit for samples from the Drenthe Plateau. The latter sand samples from the Boxtel Formation were not further distinguished on their facies, so it is unclear whether all the sand samples were cover sands.

Fluvio-aeolian deposits have often been distinguished by Dutch geologists, for example classified under the former Twente Formation and the recently introduced Boxtel Formation. Schokker et al. (2005) observed that the $\mathrm{Na}_{2} \mathrm{O}$ to $\mathrm{Al}_{2} \mathrm{O}_{3}$ ratio for sandy fluvio-aeolian sediments from the Boxtel Formation was lower than that of sandy, fluvial sediments from the 
Sterksel Formation or aeolian sediments from the same Boxtel Formation. This implies lower Na-feldspar contents in favour of other $\mathrm{Al}$ minerals and points to different provenances. Hartog et al. (2005) characterised a few such shallow samples from the eastern Netherlands on their carbonate isotopes and sedimentary organic matter composition. They found strongly depleted $\delta^{18} 0$ and $\delta^{13} \mathrm{C}$ values down to $-3 \%$ and $-8 \%$ associated with anomalously high carbonate contents of about $5 \%$. Such carbonates were concluded to be authigenically produced ferroan ones. This illustrates the importance of local palaeohydrological and diagenetic processes within a fresh groundwater environment.

Locally, red sands are found at the surface in the Veluwe and other locations in the Pleistocene area of the Netherlands, mostly in the cover sands (Weenig, 1951; Bakker \& Rogaar, 1993). They occur in the most upstream parts of brook valleys or in dry valleys and extend over several tens to hundreds of square metres. These sands are enriched in goethite, haematite and maghaemite, and are surrounded by similar sands that are not red. The $\mathrm{Fe}_{2} \mathrm{O}_{3}$ enrichments above the background level can be as high as $59.7 \mathrm{~kg} / \mathrm{m}^{2}$ within $80 \mathrm{~cm}$ depth, which is equivalent to about $43,600 \mathrm{mg} / \mathrm{kg}$ dry weight. The sands probably originated from groundwater exfiltration under palaeohydrological conditions, supported by the association with gley phenomena (Bakker \& Rogaar, 1993).

\subsection{Peat}

About $9 \%$ of the Dutch terrestrial surface consists of peat soils; they are especially present in the western and northern Holocene lowlands but also in the Pleistocene landscape as bogs and as fens in alluvial valleys. The Holocene peat layers are lithostratigraphically classified as the Nieuwkoop Formation and they are found both at the surface and buried. The Eemian Woudenberg Formation is also composed of peat and occurs on the lateral fringe with the marine Eem Formation on top of it. Peat layers are also found at local scale in many other terrestrial formations. Peat is defined in the Netherlands as geomaterial that contains more than $15-30 \%$ organic matter, depending on the percentage of clay. This definition implies that the clastic component can be very substantial. Below, we have indicated the kind of peat studied where it must be concluded that Dutch peat has been scarcely studied mineralogically and relationships with type and landscape settings are unclear.

Van Bemmelen (1896) visually observed at a peat bog in southeastern Drenthe white, amorphic Fe carbonate as local enrichments in the compacted bottom layer on top of iron ore deposits in a sand layer. The chemical analysis indicated that the white solid is fairly pure $\mathrm{FeCO}_{3}$ with about $5 \% \mathrm{CaCO}_{3}$. In another shallower layer he observed vivianite fading into blue that also contained $\mathrm{FeCO}_{3}$. The Fe content of the bottom layer rich in Fe carbonate was higher than that of the vivianite layer and peat in general. Van Bemmelen \& Reinders (1901) also ob- served whitish crystalline and amorphous Fe carbonate with or without blue-fading vivianite in a peat sublayer under tubular bog iron ore (see below). It is worth pointing out that Smittenberg et al. (1998) did not observe siderite in addition to calcite and vivianite in Late Pleistocene buried peat layers along the Meuse river whereas they did in the associated gyttja layer (see elsewhere). In this layer, $\mathrm{HCO}_{3}$ is probably present as a result of decomposition of peat, and the supply of Fe may be the limiting factor for siderite formation in the peat. Otherwise, a subtle difference in $\mathrm{pH}$ may be limiting. The formation of siderite has been attributed to diagenesis under the influence of exfiltrating Fe-rich groundwater. Van Rossum (1996, 1998) found pyrite in basal peat in the western Netherlands using electron microscopy. It occurs as framboids of around $15 \mu \mathrm{m}$ and octahedral crystals from $<1$ to $5 \mu \mathrm{m}$, where it can be associated with clay minerals or solid organic matter. Similarly, pyrite has also been observed in a peat sample of the Boxtel Formation at the Peel Horst, where it can be as large as $1.2 \mathrm{~mm}$ in diameter in association with plant remains (Fig. 15; RGD, 1989).

Van Helvoort et al. (2007) analysed a series of Holocene peat samples from the riverine area that were rich in clastic material and originated from peat bogs. They found median values of $2.34 \%$ for the pyrite content and $2.39 \%$ for the Ca carbonate content. The pyrite content was calculated from the total $\mathrm{S}$ content and not corrected for organic $S$. The weight ratio between organic $C$ and organic $S$ is $60-200: 1$ for peat in freshwater environments (Price \& Casagrande, 1991; Bartlett et al., 2005), with a typical value of 100:1. For marine peat or freshwater peat that has undergone marine influence, lower ratios are observed: down to 15:1. The organic $S$ content in peat may thus be several tenths of a per cent (or even a few per cent when there has been marine influence), which cannot be neglected when compared to total S measurements for peat. Table 30 summarises statistical data on the reactive solids of peat; the data for the first four groups are more reliable than those for the last two. All these data show that the pyrite content can be high whereas the Ca carbonate content generally remains low. This implies that peat may be susceptible to acidification when pyrite oxidises aerobically and carbonate buffering capacity is insufficient (Van Helvoort et al., 2007). Van Bemmelen's (1896) observations are thus probably local anomalies. Peat in the regionally occurring Nieuwkoop Formation seems to contain more organic matter than peat that occurs as local layers in the other formations. As presented in Table 25, Vos \& De Wolf (1993) found no diatoms in a layer of Phragmite peat from a core in Zeeland. This finding cannot be generalised, as evidenced by Watermann et al. (2004) for comparable peat layers in German Holocene coastal deposits: both fresh and saline water types may be present and they probably originate from flood events.

Tambach et al. (2009) analysed a sample from a Late Pleistocene buried peat layer on its organic geochemistry. The sample originated from a drilling in the IJssel river valley, Gelderland. They found that it was composed of about $30 \%$ pyrolysable 
Fig. 15. SEM backscatter image of a polished thin section showing pyritised plant remains as observed in a buried peat layer of the Boxtel Formation at the Peel Horst (derived from $R G D, 1989)$.

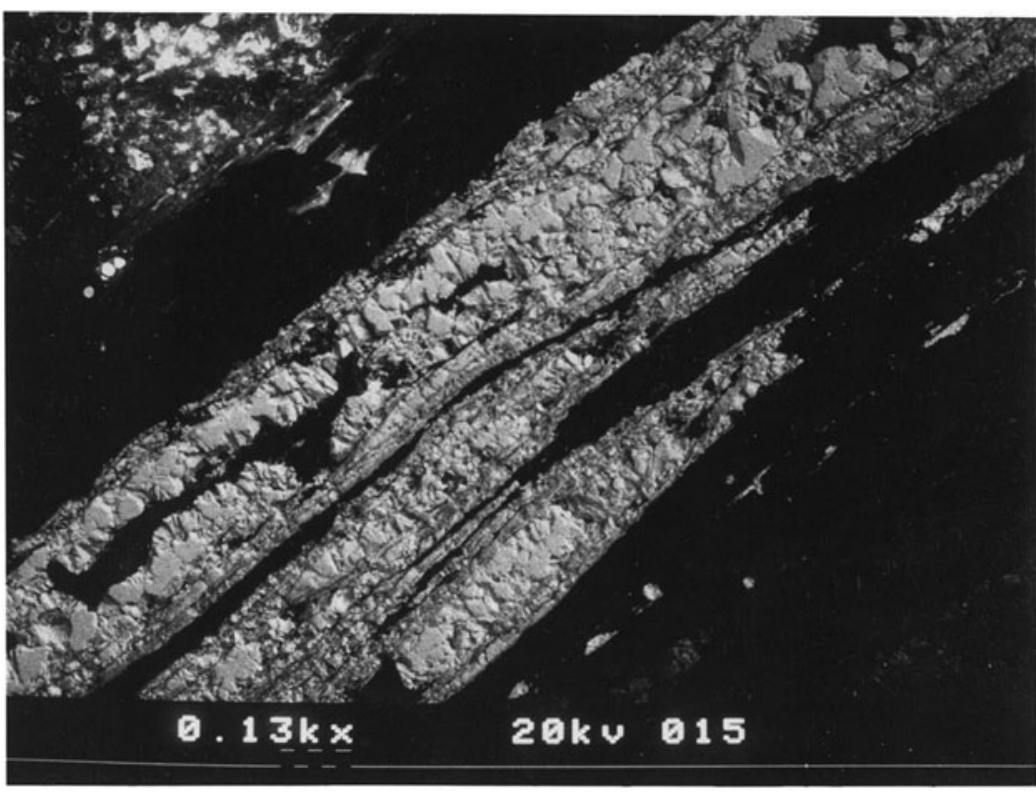

Table 30. Regional characteristics (as percentiles) of the Ca carbonate, clay, organic matter and pyrite contents (in wt\%) of peat in different combinations of region and geological unit. The data largely refer to peat deeper than $1 \mathrm{~m}$ below surface.

\begin{tabular}{|c|c|c|c|c|c|c|c|c|c|c|c|}
\hline \multirow[b]{2}{*}{ Region } & \multirow{2}{*}{$\begin{array}{l}\text { Geological } \\
\text { formation }\end{array}$} & \multirow[b]{2}{*}{ Samples } & \multicolumn{2}{|c|}{$\begin{array}{c}\mathrm{Ca} \\
\text { carbonate }\end{array}$} & \multicolumn{2}{|c|}{ Clay } & \multicolumn{2}{|c|}{$\begin{array}{l}\text { Organic } \\
\text { matter }\end{array}$} & \multicolumn{2}{|c|}{ Pyrite $^{a}$} & \multirow[b]{2}{*}{ Reference } \\
\hline & & & p50 & $\mathrm{p} 82.5$ & $\mathrm{p} 50$ & p82.5 & p50 & $\mathrm{p} 82.5$ & p50 & $\mathrm{p} 82.5$ & \\
\hline Zeeland & Nieuwkoop & 13 & 0.5 & 1.7 & - & - & 85.8 & 94 & 0 & 4.6 & Vermooten et al. (2011) \\
\hline Northern Netherlands & Nieuwkoop & 66 & 1.1 & 1.9 & 3.7 & 77 & 80.2 & 93.2 & 4.7 & 10.6 & Klein \& Griffioen (2012) \\
\hline Northern Netherlands & Boxtel & 25 & 0.9 & 1.4 & 5.1 & 8.7 & 37.7 & 78.3 & 1.3 & 2 & Klein \& Griffioen (2012) \\
\hline \multirow[t]{2}{*}{ Northern Netherlands } & Urk-Tijnje & $11 / 14$ & 0.9 & 2.8 & 5.6 & 15.9 & 55.4 & 83 & 2.4 & 6.3 & Klein \& Griffioen (2012) \\
\hline & & & & & & & & & & p90 & \\
\hline Western and riverine area & Nieuwkoop & $23 / 433$ & $12.7^{b}$ & $21.3^{b}$ & - & - & 48.3 & 86.7 & 5.48 & 12.9 & Van Gaans et al. (2007) \\
\hline Western and riverine area & Kreftenheije $e^{c}$ & 27 & 6.4 & 43.4 & - & - & - & - & 5 & 12.5 & Van Gaans et al. (2007) \\
\hline
\end{tabular}

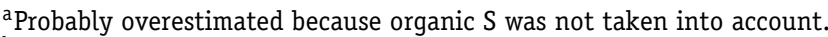

${ }^{b}$ Probably overestimated because exchangeable Ca was not taken into account and gyttja samples were included.

'Probably erroneous because gyttja samples were also classified as peat.

carbon and about $70 \%$ residual carbon, with the former being dominated by hydrocarbon material instead of $\mathrm{CO}$ and $\mathrm{CO}_{2}$. The amount of pyrolysable carbon is calculated from the amount of hydrocarbons, $\mathrm{CO}$ and $\mathrm{CO}_{2}$ generated during heating of a sample without any oxidation and the amount of residual carbon is calculated from the amount of $\mathrm{CO}$ and $\mathrm{CO}_{2}$ generated upon complete oxidation and heating of the pyrolysis residual fraction (Behar et al., 2001).

\subsection{Bog ore}

Strictly speaking, bog ore (or bog iron ore) is not a type of sediment but a diagenetic precipitate or iron containing minerals in a substrate. It was used in the past for iron production, especially in the Vecht area in Overijssel (Joosten, 2004). As its mineralogical and geochemical compositions and other properties are very different than those of regular sediments, it is reviewed separately. When it was exploited as Fe ore, the main constituent was goethite, in fractions varying between $45 \%$ and 95\% (Joosten, 2004). However, siderite and vivianite can also be major minerals in bog ore (Fig. 16). It has been found in sandy deposits at the bottom of peat layers, in alluvial deposits in brook valleys and also within peat layers as tubular crusts or powder (Van Bemmelen \& Reinders, 1901; Reinders, 1902; Booij, 1986; Landuydt, 1990). Its diagenesis has always been linked with exfiltration of Fe-containing groundwater in low-lying areas, where two diagenetic types have been distinguished. It is worth pointing out that bog ore may contain high contents of the trace elements arsenic, cobalt and barium (Van Pruissen \& Zuurdeeg, 1988; Joosten, 2004). 


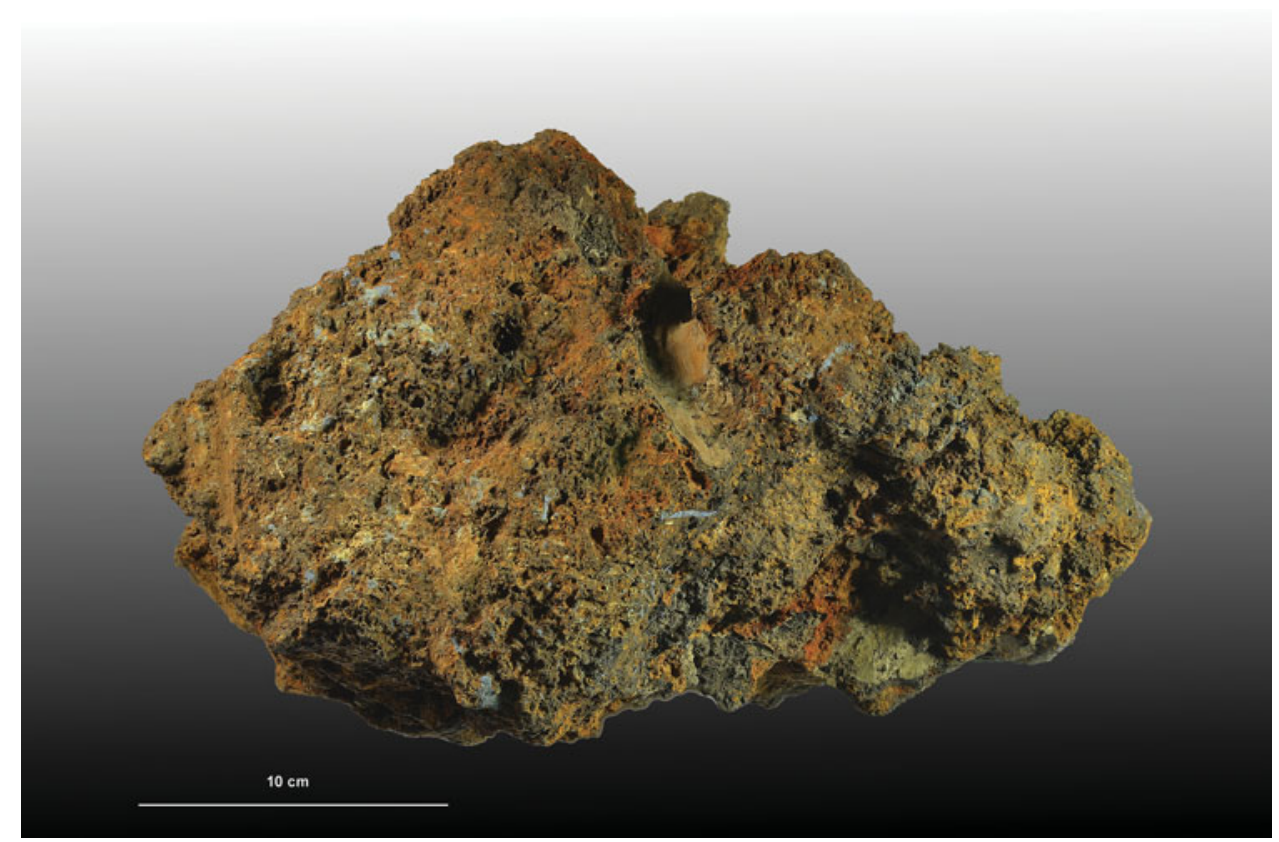

Fig. 16. Bog ore with blue-discoloured, oxidised vivianite as found during construction of the entry of the high-speed traintunnel near Leiden, South-Holland.

Van Bemmelen \& Reinders (1901) mentioned that the iron nodules in the sand layer are composed of hard and soft parts, with siderite cementing the sand matrix in the hard parts and Fe oxide being more dominant in the soft parts. They also mentioned the presence of ferro-silicate crystals $18 \mu \mathrm{m}$ long and 3 $\mu \mathrm{m}$ wide, without further specifying the chemical composition or mineralogy. The diagenesis is due to near-vertical exfiltration of Fe-containing groundwater. This bog ore is found in the upper part of the sand or in the peat immediately above. The tubular crusts in the peat layer were composed of Fe oxide with some Fe phosphate and no Fe carbonate; they were root and stem remnants and had an outer diameter of 4-6 $\mathrm{mm}$ and an inner diameter of 0.9-1.5 mm. Van Bemmelen \& Reinders (1901) attributed the existence of tubular Fe oxides to flow of anoxic Fe-rich groundwater from the Pleistocene area through the peat lands, with production of Fe oxides close to the groundwater table under exposure to air. Additionally, Reinders (1902) explained the existence of powdered bog iron as precipitation of Fe oxides around less woody plants (such as herbs) under similar hydrological conditions. Siderite may be present in a peat sublayer below the bog iron but not in contact with the sand below. These bog ores have always been found near brooks within bog complexes and they are called moerasijzererts in Dutch.

Landuydt (1990) characterised the micromorphology of the typical Fe minerals for bog ore along the Nete brooks in the Campine region (Belgium), just south of Breda. Here, goethite usually occurs as coatings on walls and voids or, secondarily, as nodules of $<1 \mathrm{~mm}$ to $5 \mathrm{~cm}$ in diameter, together with ferrihydrite. Siderite is found dispersed as tiny crystals or as spherical, radial nodules $50-200 \mu \mathrm{m}$ in diameter. Vivianite often occurs as microcrystalline void infillings or aggregates $1-3 \mathrm{~mm}$ in diameter.

\section{Discussion}

The previous sections describe the mineralogy of the different kinds of Cenozoic deposits that are found in the Netherlands together with related recent sediments and suspended matter. This section evaluates the reviewed literature in terms of two major topics: (1) achievements at national level and (2) knowledge gaps that still need to be addressed per group of minerals, as seen from the perspective of the geo-information needs of the Netherlands.

\subsection{Mineralogical characterisation of Dutch sediments and suspended matter}

Many of the studies reviewed dealt with small amounts of samples: from a few to several dozens of samples. Notable exceptions are the studies dealing with long borehole cores, and the geotop programme of the TNO Geological Survey (Griffioen et al., 2012 and related reports). For the latter, a systematic geochemical characterisation is currently in progress for the first tens of metres of the subsurface as part of a broad geoscientific characterisation programme (Van der Meulen et al., 2013). Under this programme, specific geochemical and grain size analyses are being recalculated to obtain contents of $\mathrm{Fe}$ sulphide, carbonates, organic matter, non-sulphide reactive Fe minerals and clay (Van Gaans et al., 2011). Little insight thus exists on the spatial representativeness of the individual 
studies for other geographical areas. This hampers environmental management of the Netherlands at the local to national level, as the mineralogical information is useful for the reasons mentioned in the introduction.

The complete suite of manuscripts reviewed also indicates that until the 1970s the mineralogical characterisation entailed using optical microscopes. Since then, geochemical techniques have been applied much more frequently, although wet chemical extraction techniques had also been used previously. The most densely studied areas are the Scheldt systems. This seems to be due to a combination of reasons: (1) research groups from both the Netherlands and Belgium have been active here, (2) the Western Scheldt system was severely polluted with nutrient and trace metals and is still recovering from this, and (3) there is academic interest in biogeochemical cycling in these estuarine environments, particularly of carbon and sulphur. The paucity of studies on glacial sediments and peat is striking, given the widespread occurrence of the former and the importance of the latter as soil and landscape types in the Netherlands. Hardly any mineralogical studies have been done in the provinces of North Holland, Flevopolder, Friesland and Groningen (outside the Wadden Sea) and coastal dunes. Assumptions on the mineralogy of the sediments present in these provinces must thus be based on spatial extrapolation from other parts of the Netherlands, together with more general mineralogical insights. Finally, the number of studies that deal with sediments deeper than $30 \mathrm{~m}$ is also limited.

\subsection{Heavy minerals}

Heavy mineral associations have been characterised routinely in the past for many kinds of sediments in many kinds of borehole cores. Regrettably, the absolute amounts of these minerals were rarely measured. Such data would be useful to better estimate the role of weathering of these minerals relative to that of micas and plagioclase in relation to acid buffering in the acid sandy soils that are frequently found in the Netherlands (Mol, 2002; Van der Salm \& Verstraten, 1994) and evolution of the groundwater composition in non-calcareous aquifers (Griffioen et al., 2013). The systematic removal of individual heavy minerals during weathering is a topic that deserves further attention because errors can be made in the stratigraphical interpretation when this phenomenon is overlooked.

Most previous work on heavy minerals in the Rhine River (e.g. Van Andel, 1950; Westerhoff et al., 2008; Krippner \& Bahlburg, 2013) focused on transparent minerals (e.g. garnet, epidote, hornblende, tourmaline and zircon), their proportions and/or $\mathrm{U}-\mathrm{Pb}$ age dating of zircons.The latter method is valuable for characterisering the provenance areas of sediments. It brought Krippner \& Bahlburg (2013) to question the commonly made assumption of a direct delivery of detritus to the downstream Rhine river system from the Alps during at least some parts of the Pleistocene. This would also necessitate the re-evaluation of explanations on the provenance of Dutch sediments.

\subsection{Clay minerals}

Several studies have used XRD to examine the clay mineralogy of fluvial and marine sediments, but the glacial sediments are under-represented. The outcomes indicate that a mixture of clay minerals is always present, with variations in the individual fractions. Systematic differences have been noted between fluvial clays, alluvial clays and marine Tertiary or Quaternary clays. Typically, from 5 to 20 samples were characterised in the individual studies. One can but wonder how much practical geoinformation insight would have been obtained if much larger numbers of samples had been analysed. Although considerable advances have been made in the level of detail of XRD analysis of clay minerals, many more insights into the geological controls of sedimentary clay mineralogy could be obtained by increasing the density of sampling of the sedimentary records (Zeelmaekers, 2011).

\subsection{Feldspars and micas}

The presence of feldspars and micas in marine sediments has hardly been studied, even though it is relevant within the context of long-term weathering of these sediments, as feldspars may be a potential source of major elements such as $\mathrm{Na}$ and $\mathrm{K}$, and trace elements such as Ba. It would also improve understanding of diagenesis in groundwater environments as an intermittent stage in the diagenetic evolution from the original sedimentary environment to the conditions present in deep oil and gas reservoirs. Another shortcoming in the mineralogical characterisation is the lack of insight into the occurrence of black biotite in addition to silverish micas. A few studies have pointed out the presence of biotite, but these characterised only small numbers of samples. Biotite is more susceptible to weathering than muscovite, however, and it may be a source of $\mathrm{Mg}$, Fe and also $\mathrm{F}$ in pore water.

\subsection{Ca carbonates}

The review indicates that the origin of $\mathrm{Ca}$ carbonates may be diverse within a sediment type: primary rock carbonates and secondary soil carbonates from the hinterland are transported by the rivers, together with possibly authigenic Ca carbonate. These are mixed with other carbonates in estuaries and just offshore. Calcium carbonate in the marine environment also refers to old rock carbonates (but which may be from another provenance than the carbonates transported in the rivers), authigenic young shells and their fragments and in situ precipitated Ca carbonate (where dissolution may also take place, particularly in supratidal flats). The different kinds of Ca carbonate present may have different ranges in $\delta^{13} \mathrm{C}-\mathrm{CO}_{3}, \delta^{18} 0-\mathrm{CO}_{3}$ and ${ }^{14} \mathrm{C}$ 
age. As a result, many sediments will be an isotopic mixture of carbonates. The presence of different kinds of carbonates within an individual sediment that may be involved in dissolution processes has implications for groundwater dating, for example on the need to correct from apparent age to true age when using ${ }^{14} \mathrm{C}$ analysis.

Another complicating issue for $\mathrm{Ca}$ carbonates is the presence of dolomite versus calcite and aragonite. It is clear that dolomite plays a role in Dutch marine and fluvial sediments. It seems likely that calcite and aragonite are more susceptible to leaching than dolomite because of the differences in kinetic dissolution rates. A sediment would thus gradually become more enriched in dolomite than in pure Ca carbonates. Ritsema \& Groenenberg (1993) observed this phenomenon in a marine clay soil and Van der Sleen (1912) described it for the older, inner coastal dunes at a few locations along the western coast, but it has not yet been generally acknowledged and has been studied even less.

\subsection{Reactive Fe minerals}

The occurrence of reactive Fe minerals has been studied frequently but enigmatic questions still remain for the Dutch settings. The focus has been on Fe sulphides in the Eastern and Western Scheldt estuaries, but studies have also examined Fe sulphides in other environments. There are clear indications that pyrite is present not only in marine sediments or terrestrial sediments that have been subject to marine environments, but also in fluvial environments that remained terrestrial for more than 1 million years (e.g. the Waalre and Sterksel Formations in the southern Netherlands). A source for sulphide must have been present to diagenetically produce such pyrites: we believe that it is $\mathrm{SO}_{4}$ dissolved in the river Rhine (or other rivers), as the $\mathrm{SO}_{4}$ concentration in the Rhine under natural conditions was around $35 \mathrm{mg} / \mathrm{L}$ (Griffioen et al., 2008). Given sufficient time and sufficient river bank infiltration, the Rhine may yield sufficient $\mathrm{SO}_{4}$ to produce regionally dispersed pyrite in aquifer sediments.

Less well studied in the Netherlands are siderite, Fe oxyhydroxides, glauconite and vivianite. These minerals can be grouped together as non-pyrite reactive iron, which is being statistically characterised at regional scale under the ongoing national geotop programme (Van Gaans et al., 2011; Van der Meulen et al., 2013). Based on the existing data on Dutch sediments, it is impossible to make any further distinctions between these minerals even though their geochemical properties are very different. Additional insights would therefore be very welcome for these sediments on this type of minerals.

Siderite has been incidentally identified when focusing on concretions. The environment in which such concretions form will be somewhat exceptional and the insights obtained into the siderite diagenesis cannot be extrapolated to the geoscientific settings of similar sediments in which these concretions do not occur. Insight into the diagenesis of dispersed siderite is needed, amongst other reasons to better understand its importance in controlling the groundwater chemistry, as much groundwater in the Netherlands is saturated or supersaturated in siderite but not necessarily saturated in calcite (Griffioen et al., 2013).

Iron oxyhydroxides are important with respect to the buffering capacity of sediments and soils against reduction, and as sorbent for trace elements and other solutes. There is no general insight into the presence and related diagenesis of these minerals in Dutch sediments deeper than the soil horizons (Fig. 17). The presence of detrital Fe oxides has been shown microscopically for Meuse sediments in southern Limburg and a few more sites, but the spatial representativeness of these observations is largely limited to the southeastern part of the Netherlands. Insight into the systematic presence or absence of detrital Fe oxyhydroxides in Dutch sediments is crucial, but is currently lacking. Extractions have been used to indicate the amount of Fe oxyhydroxides in Dutch sedimentary environments, but there is always a possibility of interference from other solids during the Fe oxide extraction (Martin et al., 1987; La Force \& Fendorf, 2000). The results of these extractions also suggested the presence of Fe oxyhydroxides under $\mathrm{SO}_{4}$-reducing conditions (Canavan et al., 2006). This is an important observation because it shows that not all Fe oxyhyroxides present can be microbially reduced for the given time scale and that under reduced conditions an oxic mineral remains present that will be part of the sediment sorption capacity. The presence of Fe oxyhydroxides under $\mathrm{SO}_{4}$-reducing conditions needs to be confirmed using other characterisation techniques.

\subsection{Peat and sedimentary organic matter}

The characterisation of peat and sedimentary organic matter in Dutch conditions is poor. A very limited series of studies applied mineralogical or geochemical characterisation methods to peat. The early studies (around 1900) on vivianite and siderite in peat are still unique. It must be remembered that most peats are not completely composed of organic matter but may contain more than $50 \%$ of clastic material as well. Knowledge about the mineralogical composition of this clastic component is important as this composition affects the reactivity of the peat in different ways. The findings may help to address technical issues such as subsidence of peatlands, the natural background load of nutrients in the associated surface water system, nature restoration, etc.

Only a few studies have addressed the composition of organic matter; most have focused on fresh sediments and suspended matter in the southern North Sea. Studies of the type performed for the Dutch marine environment would also be very useful for the Dutch limnological environment, for which there are still surface water quality issues (Van Puijenbroek et al., 


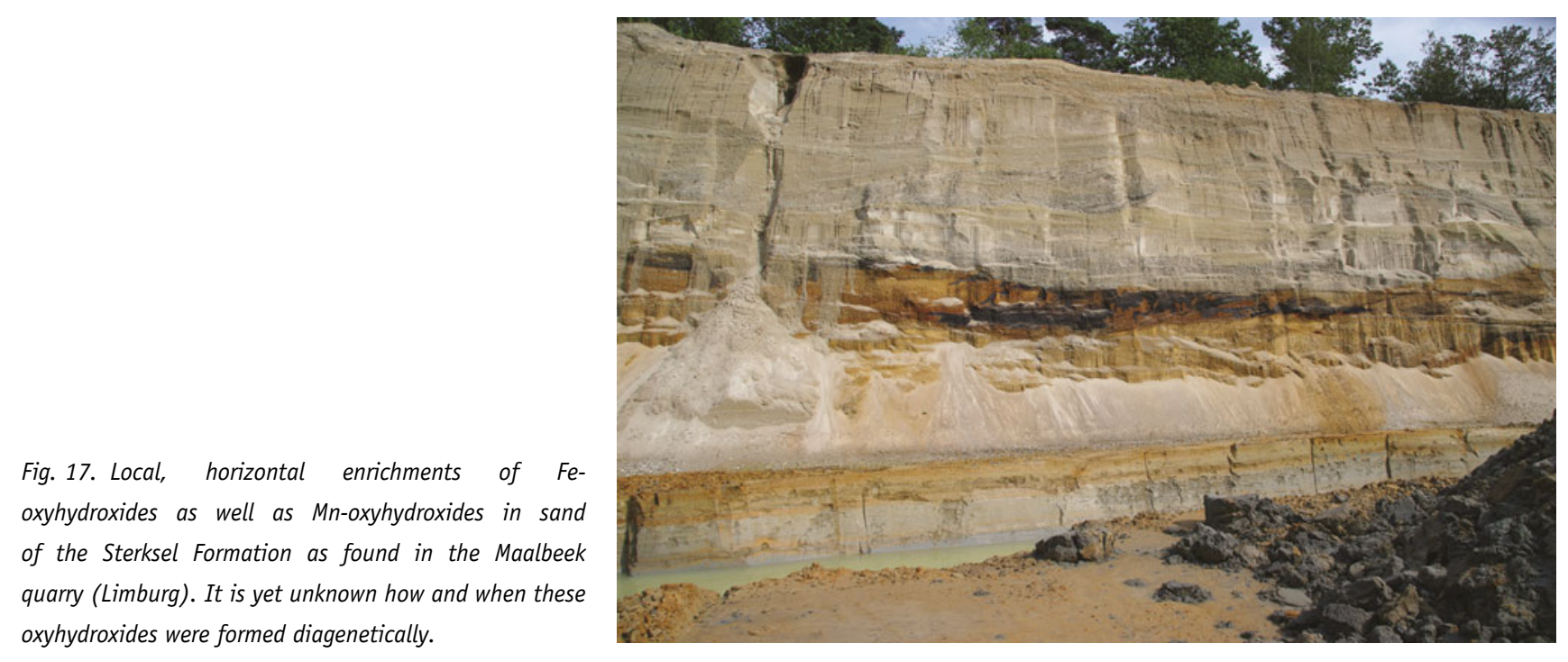

2004; Janse et al., 2010). Further, microcosm respiration experiments on small numbers of samples have yielded information on the redox reactivity of different kinds of sediments present. These experiments have elucidated the role of organic matter oxidation versus oxidation of reactive $\mathrm{Fe}(\mathrm{II})$ minerals, which is amongst other things relevant for aquifer storage and recovery (Prommer \& Stuyfzand, 2005; Antoniou et al., 2012). More generally, insight into the functional and molecular composition of sedimentary organic matter would be fruitful to clarify the reactivity and diagenetic history of sediments, in particular of Dutch sediments.

\section{Acknowledgments}

The librarians of Deltares are gratefully acknowledged for collecting many old and very old references as well as some more recent ones. We thank our colleagues Aleid Bosch, Wim Dubelaar, Sytse van Heteren (all TNO) and Harry Veld (Deltares) for commenting on an earlier version of the manuscript or parts of it. Holger Cremer (TNO) and Albert 0ost (Deltares) are thanked for introducing us to the world of Dutch diatoms and shells, respectively. The two reviewers and editor Ronald van Balen are thanked for their very precise and constructive comments. Joy Burrough was the language editor of a near-final draft of the manuscript. Reference is made to the website www.dinoloket.nl as it was in August 2014.

\section{References}

Abril, G., Nogueira, M., Etcheber, H., Cabecadas, G., Lemaire, E. \& Brogueira, M.J., 2002. Behaviour of organic carbon in nine contrasting European estuaries. Estuarine and Coastal Shelf Science 54: 241-262.
Adriaens, $R$., 2014. Staalname en analyse TNO/Deltares. Doctoraatsproject, KU Leuven: $14 \mathrm{pp}$.

Algemeen, Handelsblad, 1923. Nederl. Natuur- en Geneeskundig Congres. Algemeen Handelsblad, 6 April 1923. Avondblad: p. 2.

Alizai, A., Hillier, S., Clift, P.D., Giosan, L. \& Hurst, A., 2012. Clay mineral variations in Holocene terrestrial sediments from the Indus Basin. Quarternary Research 77: 368-381.

Anderson, W.F., 1970. Massaal voorkomen van radiolariën in het keileem van Altstätte. Grondboor \& Hamer. 24: 153-156.

Antoniou, E.A., Van Breukelen, B.M., Putters, B. \& Stuyfzand, P.J., 2012. Hydrogeochemical patterns, processes and mass transfers during aquifer storage and recovery (ASR) in an anoxic sandy aquifer. Applied Geochemistry 27: 2435-2452.

Asselman, N.E.M., 1999. Suspended sediment dynamics in a large drainage basin: the River Rhine. Hydrological Processes 13: 1437-1450.

Baak, J.A., 1936. Regional petrology of the southern North Sea. Ph.D. thesis, Agricultural University, Wageningen.

Baeye, M., Fettweis, M., Voulgaris, G. \& Van Lancker, V., 2011. Sediment mobility in response to tidal and wind-driven flows along the Belgian inner shelf, southern North Sea. 0cean Dynamics 61: 611-622.

Baeyens, B., Maes, A. \& Cremers, A., 1985. In situ physico-chemical characterization of Boom Clay. Radioactive Waste Management Nuclear Fuel Cycle 6: 391-408.

Baeyens, W., Van Eck, B., Lambert, C., Wollast, R. \& Goeyens, L., 1998. General description of the Scheldt estuary. Hydrobiologia 366: 1-14.

Bakker, D.C.E. \& Rogaar, H., 1993. Roodzand op de Veluwe. Grondboor \& Hamer 47: 24-28.

Bakker, I., Kiden, P., Schokker, J. \& Griffioen, J., 2007. De geotop van de ondergrond: Een reactievat. Deelrapport 2. Eerste statistische karakterisatie van de geochemische reactiecapaciteit van het topsysteem in Noord-Brabant en het noorden van Limburg. TNO Bouw en Ondergrond, rapport no. 2007-UR0324/A.

Bartlett, R., Bottrell, S. \& Coulson, J., 2005. Behaviour of sulphur during diagenesis of a maritime ombrotrophic peat from Yell, Shetland Islands, UK. Applied Geochemisttry 20: 1597-1605. 
Bates, A.L., Spiker, E.C. \& Holmes, C.W., 1998. Speciation and isotopic composition of sedimentary sulfur in the Everglades, Florida, USA. Chemical Geology 146: 155-170.

Beeftink, W.G., Daane, M.C., Van Liere, J.M. \& Nieuwenhuize, J., 1977. Analysis of estuarine soil gradients in the salt marshes of the southwestern Netherlands with special reference to the Scheldt estuary. Hydrobiologia 52: 93-106.

Beets, C.J. \& Beets, D.J., 2003. A high resolution stable isotope record of the penultimate deglaciation in lake sediments below the city of Amsterdam, The Netherlands. Quaternary Science Reviews 22: 195-207.

Beets, D.J. \& Van der Spek, A.F.J., 2000. The Holocene evolution of the barrier and the back-barrier basins of Belgium and the Netherlands as a function of late Weichselian morphology, relative sea-level rise and sediment supply. Netherlands Journal of Geosciences 79: 3-16.

Beets, D.J., Beets, C.J. \& Cleveringa, P., 2006. Age and climate of the late Saalian and early Eemian in the type-area, Amsterdam basin, the Netherlands. Quaternary Science Reviews 25: 876-885.

Behar, F., Beaumont, V. \& De B. Penteado, H.L., 2001. Rock-Eval 6 Technology: Performances and Developments. 0il \& Gas Sci. Technol. - Rev. IFP 56: 111134.

Beukema, J.J. \& Cadée, G.C., 1999. An estimate of the sustainable rate of shell extraction from the Dutch Wadden Sea. Journal of Applied Ecology 36: 49-58.

Boenigk, W., 1974. Zur Kenntnis des Altquartärs bei Brüggen. Sonderveröffentlichen Geologische Institut Universität Köln 41: 9-18.

Boenigk, W., 2002. The Pleistocene drainage pattern in the lower Rhine basin. Netherlands Journal of Geosciences 81: 201-209.

Boggs, S., 2009. Petrology of Sedimentary Rocks. Cambridge University Press: 600 pp.

Booij, A.H., 1986. IJzeroer in Drenthe. Ontstaan, voorkomen, winning en gebruik. In: Nieuwe Drentsche Volksalmanak. Van Gorcum (Assen): 66-87.

Boon, A.R. \& Duineveld, G.C.A., 1996. Phytopigments and fatty acids as molecular markers for the quality of near-bottom particulate organic matter in the North Sea. Journal of Sea Research 35: 279-291.

Boschker, H.T.S., Brouwer, J.F.C. \& Cappenberg, T.E., 1999. The contribution of macrophyte-derived organic matter to microbial biomass in salt-marsh sediments: Stable carbon isotope analysis of microbial biomarkers. Limnology and Oceanography 44: 309-319.

Bouezmarni, M. \& Wollast, R., 2005. Geochemical composition of sediments in the Scheldt estuary with emphasis on trace metals. Hydrobiologia 540: 166168.

Breeuwsma, A., 1985. Kleimineralogische en chemische karakteristieken van zeeklei, rivierklei en beekklei., Rapport no. 1869. Stichting voor bodemkartering (Wageningen): $34 \mathrm{pp}$.

Breeuwsma, A. \& Zwijnen, P., 1984. Kleimineralogische samenstelling van Nederlandse aquifers. Rapport no. 1816. Stichting voor bodemkartering (Wageningen): $7 \mathrm{pp}$.

Breeuwsma, A., Balkema, W. \& Zwijnen, P., 1987. Kleimineralogische onderzoek van enkele Kwartaire en Tertiaire afzettingen. Rapport no. 1980. Stichting voor bodemkartering (Wageningen): $19 \mathrm{pp}$.

Brockamp, 0. \& Clauer, N., 2012. Clay mineral provinces in tidal mud flats at Germany's North Sea coast with illite K-Ar ages potentially modified by biodegradation. Estuar. Coastal Shelf Science 107: 32-45.

Bruin, $\boldsymbol{P}$., 1938. De aanwezigheid van calcium-magnesium-carbonaat naast calciumcarbonaat in kleigronden en de ontleding dezer carbonaten onder invloed van zoutzuur, azijnzuur en de bodemzuren. Verslagen Landbouwkundige 0nderzoekingen 44 (15)A: 693-738.

Buijs, E.A. \& Van der Grift, B., 2001. Reactiviteit ondergrond ten behoeve van Aquifer Storage Recovery (ASR) in Limburg. TNO-NITG, rapport no. NITG 01056-B: $25 \mathrm{pp}$.

Busschers, F.S., Kasse, C., Van Balen, R.T., Vandenberghe, J., Cohen, K.M., Weerts, H.J.T., Wallinga, J., Johns, C., Cleveringa, P. \& Bunnik, F.P.M., 2007. Late Pleistocene evolution of the Rhine-Meuse system in the southern North-Sea Basin: imprints of climate change, sea-level oscillation and glacioisostacy. Quaternary Science Reviews 26: 3216-3248.

Buurman, P., Pape, Th., Reijneveld, J.A., De Jong, F. \& Van Gelder, E., 2001. Laser-diffraction and pipette-method grain sizing of Dutch sediments: correlations for fine fractions of marine, fluvial, and loess samples. Netherlands Journal of Geosciences 80: 49-57.

Canavan, R.W., Slomp, C.P., Jourabchi, P., Van Cappellen, P., Laverman, A.M. \& Van den Berg, G.A., 2006. Organic matter mineralization in sediment of a coastal freshwater lake and response to salinization. Geochimica et Cosmochimica Acta 70: 2836-2855.

Canavan, R.W., Van Cappellen, P., Zwolsman, J.J.G., Van den Berg, G.A. \& Slomp, C.P., 2007. Geochemistry of trace metals in a fresh water sediment: Field results and diagenetic modelling. Science of the Total Environment 381: 263-279.

Canfield, D.E., Raiswell, R. \& Bottrell, S., 1992. The reactivity of sedimentary iron minerals toward sulfide. American Journal of Science 292: 659-683.

Carbonnel, V., Vanderborght, J.P., Lionard, M. \& Chou, L., 2013. Diatoms, silicic acid and biogenic silica dynamics along the salinity gradient of the Scheldt estuary (Belgium/The Netherlands). Biogeochemistry 113: 657-682.

Chafetz, H.S. \& Reid, A., 2000. Syndepositional shallow-water precipitation of glauconitic minerals. Sedimentary Geology 136: 29-42.

Chambers, R.M. \& Pederson, K.A., 2006. Variation in soil phosphorus, sulfur, and iron pools among south Florida wetlands. Hydrobiologia 569: 63-70.

Chen, M.S., Wartel, S., Van Eck, B. \& Van Maldegem, D., 2005. Suspended matter in the Scheldt estuary. Hydrobiologia 540: 79-104.

Cornelis, J.T., Delvaux, B., Georg, R.B., Lucas, Y., Ranger, J. \& Opfergelt, S., 2011. Tracing the origin of dissolved silicon transferred from various soil-plant systems towards rivers: a review. Biogeosciences 8: 89-112.

Cowie, G.L. \& Hedges, J.L., 1992. Sources and reactivities of amino acids in a coastal marine environment. Limnology and 0ceanography 37: 703-724.

Cremer, H., Bunnik, F.P.M., Kirilova, E.P., Lammens, E.H.R.R. \& Lotter, A.F., 2009. Diatom-inferred trophic history of IJsselmeer (The Netherlands). Hydrobiologia 631: 279-287.

Cremer, H., Bunnik, F.P.M., Donders, T.H., Hoek, W.Z., Koolen-Eekhout, M., Koolmees, H.H. \& Lavooi, E., 2010. River flooding and landscape changes impact ecological conditions of a scour hole lake in the Rhine-Meuse delta, the Netherlands. Journal of Paleolimnology 44: 789-801.

Crommelin, R.D., 1940. De herkomst van het zand van de Waddenzee. Tijdschrift van het Koninklijk Nederlands Aardrijkskundig Genootschap 57: 347-361.

Crommelin, R.D., 1943. De herkomst van het waddenslib met korrelgrootte boven 10 micron. Verhandelingen van het Geologisch Mijnbouwkundig Genootschap. Geologische Serie 13: 299-333.

Crommelin, R.D., 1945. Quantitatieve bepaling van diatomeeën in sedimenten en de beteekenis er van voor de kwartair-geologie. Verhandelingen van het Geologisch Mijnbouwkundig Genootschap. Geologische Serie XIV: 125-134. 
Crommelin, R.D., 1951. Quelques aspects granulométriques et minéralogiques de la sédimentation le long de l'estuaire de l'Éscaut. C.R. Congrès Sédimentation et Quaternaire, France, 1949: 63-71.

Crommelin, R.D., 1964. A contribution to the sedimentary petrology and provenance of Young Pleistocene cover sand in the Netherlands. Geologie \& Mijnbouw 43-9: 389-402.

Crommelin, R.D. \& Slotboom, G., 1945. Een voorkomen van granaatzandlagen op het strand van Goeree. Tijdschrift van het Koninklijk Nederlands Aardrijkskundig Genootschap LXII: 142-147.

Dauwe, B. \& Middelburg, J.J., 1998. Amino acids and hexosamines as indicators of organic matter degradation state in North Sea sediments. Limnology and Oceanography 43: 782-798.

Davies, S.M., Hoek, W.Z., Bohncke, S.J.P., Lowe, J.J., O'Donnell, S.P. \& Turney, C.S.M., 2005. Detection of Lateglacial distal tephra layers in the Netherlands. Boreas 34: 123-135.

De Brabandere, L., Dehairs, F., Van Damme, S., Brion, N., Meire, P. \& Daro, N., 2002. $\delta 13 \mathrm{~N}$ and $\delta 13 \mathrm{C}$ dynamics of suspended organnic matter in freshwater and brackish water of the Scheldt estuary. Journal of Sea Research 48: 1-15.

Decleer, J., Viaene, W. \& Vandenberghe, N., 1983. Relationships between chemical, physical and mineralogical characteristics of the Rupelian Boom Clay, Belgium. Clay Minerals 18: 1-10.

De Craen, M., Swennen, R. \& Keppens, E., 1999a. Petrography and geochemistry of septarian carbonate concretions from the Boom Clay Formation (Oligocene, Belgium). Geologie \& Mijnbouw 77: 63-76.

De Craen, M., Swennen, R., Keppens, E., Macaulay, C.I. \& Kiriakoulakis, K., 1999b. Bacterially mediated formation of carbonate concretions in the Oligocene Boom Clay of northern Belgium. Journal of Sedimentary Research 69: 1098-1106.

Deer, W.A., Howie, R.A. \& Zussmann, J., 1966. An introduction to the rockforming minerals. Longman (Harlow): $528 \mathrm{pp}$.

De Gans, W., Beets, D.J. \& Centineo, M.C., 2000. Late Saalian and Eemian deposits in the Amsterdam glacial basin. Netherlands Journal of Geosciences 79: 147160.

De Groot, A.J., 1963. Manganese status of Dutch and German Holocene deposits in relation to mud transport and soil genesis. Verslagen Landbouwkundige Onderzoekingen 69.7 (in Dutch).

Dehairs, F., Baeyens, W. \& Van Gansbeke, D., 1989. Tight coupling between enrichment of iron and manganese in North Sea suspended matter and sedimentary redox processes: Evidence for seasonal variability. Estuarine and Coastal Shelf Science 29: 457-471.

Dellwig, O., Watermann, F., Brumsack, H.-J., Gerdes, G. \& Krumbein, W.E. 2001. Sulphur and iron geochemistry of Holocene coastal peats (NW Germany): a tool for palaeoenvironmental reconstruction. Palaeogeography, Palaeoclimatology, Palaeoecology 167: 359-379.

Dellwig, O., Bottcher, M.E., Lipinski, M. \& Brumsack, H.-J., 2002. Trace metals in Holocene coastal peats and their relation to pyrite formation (NW Germany). Chemical Geology 182: 423-442.

De Meijer, R.J., 1998. Heavy minerals: from 'Edelstein' to Einstein. Journal of Geochemical Exploration 62: 81-103.

De Meijer, R.J., Lesscher, H.M., Schuiling, R.D. \& Elburg, M.E., 1990. Estimate of the heavy mineral content in sand and its provenance by radiometric methods. International Journal of Radiation Applications and Instrumentation. Part E. Nuclear Geophysics 4: 455-460.
De Mulder, E.F.J., Geluk, M.C., Ritsema, I., Westerhoff, W.E. \& Wong, T.E., 2003. The subsurface of the Netherlands. TNO Netherlands Institute of Applied Geosciences/Wolters Noordhoff: 379 pp (in Dutch).

Deniau, I., Derenne, S., Beaucaire, C., Pitsch, H. \& Largeau, C., 2001. Morphological and chemical features of a kerogen from the underground Mol laboratory (Boom Clay Formation, Oligocene, Belgium): Structure, source organisms and formation pathways. Org. Geochem. 32: 1343-1356.

Deniau, I., Derenne, S., Beaucaire, C., Pitsch, H. \& Largeau, C., 2004. 0ccurrence and nature of thermolabile compounds in the Boom Clay kerogen (Oligocene, underground Mol laboratory, Belgium). Organic Geochemistry 35: 91-107.

Deniau, I., Behar, F., Largeau, C., De Canniere, P., Beaucaire, C. \& Pitsch, H., 2005. Determination of kinetic parameters and simulation of early $\mathrm{CO}_{2}$ production from the Boom Clay kerogen under low thermal stress. Applied Geochemistry 20: 2097-2107.

De Vries, S., 2000. Literatuur- en bronnenstudie 'Vervolgonderzoek Schelpenwinning'. Geo Plus B.V./RIKZ, proj.no. 24507-00: 76 pp.

De Waard, D., 1949. Glacigeen Pleistoceen. Verhandelingen Koninklijk Nederlands Geologisch Mijnbouwkundig Genootschap 15: 70-246.

Doppert, J.W.Ch., Ruegg, G.H., Van Staalduinen, C.J., Zagwijn, W.H. \& Zandstra, J.G., 1975. Formaties van het Kwartair en Boven-Tertair in Nederland. In: Zagwijn, W.H. \& Van Staalduinen, C.J. (eds): Rijks Geologische Dienst, Toelichting bij geologische overzichtkaarten van Nederland: Ch. 2, 11-56.

Druif, J.H., 1927. Over het ontstaan der Limburgsche löss in verband met haar mineralogische samenstelling. Ph.D. thesis, Rijksuniversiteit Utrecht (Utrecht): $330 \mathrm{pp}$ and 2 enclosures.

Ebbing, J.H.J., Weerts, H.T.J. \& Westerhoff, W.E., 2003. Towards an integrated land-sea stratigraphy of the Netherlands. Quaternary Science Reviews 22: 1579-1587.

Edelman, C.H., 1933. Petrologische provincies in het Nederlandse Kwartair (Petrological provinces in the Netherlands Quaternary). Ph.D. thesis, Universiteit van Amsterdam (Amsterdam): $101 \mathrm{pp}$.

Edelman, C.H., 1934. Die Petrologie der Sande der Niederlandischen Flüssen: Rijn, Lek, Waal, Merwede and Gelderse IJsel (Sand Petrology of the Dutch rivers Rhine, Lek, Waal, Merwede and Geldersche IJssel). Mededelingen Landbouwhogeschool Wageningen (38-3). Sediment-petrologische onderzoekingen: 1.

Edelman, C.H., 1938. Ergebnisse der sedimentpetrologischen Forschung in den Niederlanden und angrenzenden Gebieten. Geologische Rundschau 43: 223271.

Edelman, C.H. \& De Smet, L.A.H., 1951. Over de ontkalking van de Dollardklei Decalcification of Dollard Clay. Boor \& Spade IV: 104-114.

Egberts, H., 1950. Soil conditions in the Betuwe. Verslagen Landbouwkundige Onderzoekingen 56.19: 82 (in Dutch).

Eisma, D., 1968. Composition, origin and distribution of Dutch coastal sands between Hoek van Holland and the island of Vlieland. Netherlands Journal of Sea Research 4: 123-267.

Eisma, D., 1981. Supply and deposition of suspended matter in the North Sea. Special publication of the International Association of Sedimentologists 5: 415-428.

Eisma, D., 1986. Flocculation and de-flocculation of suspended matter in estuaries. Netherlands Journal of Sea Research 20: 183-199. 
Elias, E.P.L., Van der Spek, A.J.F., Wang, Z.B. \& De Ronde, J., 2012. Morphodynamic development and sediment budget of the Dutch Wadden Sea over the last century. Netherlands Journal of Geosciences 91: 293-310.

Elsetinow, A.R., Schoonen, M.A.A. \& Strongin, D.R., 2001. Aqueous geochemical and surface science investigation of the effect of phosphate on pyrite oxidation. Environmental Science \& Technology 35: 2252-2257.

Engel, M.H. \& Macko, S.A., 1993. Organic geochemistry. Principles and applications. Plenum Press (New York and London): $861 \mathrm{pp}$.

Erdbrink, D.P., 1953. Enkele opmerkingen over de herkomst van löss. Grondboor en Hamer 1953: 280-286.

Ernsten, V., Gates, W.P. \& Stucki, J.W., 1998. Microbial reduction of structural iron in clays - A renewable source of reduction capacity. Journal of Environmental Quality 27: 761-766.

Fanning, D.S., Rabenhorst, M.C., May, D. \& Wagner, D.P., 1989. 0xidation state of iron in glauconite from oxidized and reduced zones of soil-geologic columns. Clays and Clay Mineralogy 37: 59-64.

Favejee, J.Ch.L., 1939. Zur Methodik der röntgenographischen Bodenforschung. Zeitschrift für Kristallographie 100: 425-436.

Favejee, J.Ch.L., 1951. The origin of the 'Wadden' mud. Med. Landbouw Hogeschool Wageningen 51: 113-141.

Feijtel, T.C., Salingar, Y., Hordijk, C.A., Sweerts, J.P.R.A., Van Breemen, N. \& Cappenberg, Th.E., 1989. Sulfur cycling in a Dutch moorland pool under elevated atmospheric S-deposition. Water, Air \& Soil Pollution 44: 215234.

Fest, E.P.M.J., Temminghoff, E.J.M., Griffioen, J., Van der Grift, B. \& Van Riemsdijk, W.H., 2007. Groundwater chemistry of Al under Dutch acid sandy soils: effects of land use and depth. Applied Geochemistry 22: 1427-1438.

Fraters, D., Boumans, L.J.M., Van Elzakker, B.G., Gast, L.F.L., Griffioen, J., Klaver, G.T., Nelemans, J.A., Veld, H. \& Velthof, G.L., 2006. Een nieuwe toetsdiepte voor nitraat in grondwater? Eindrapport van het onderzoek naar de mogelijkheden voor een toetsdieptemeetnet. RIVM/TNO/WUR/Alterra, rapportno. RIVM 680100005/2006.

Friis, H., 1974. Weathered heavy-mineral associations from the young-Tertiary deposits of Jutland, Denmark. Sedimentary Geology 12: 199-213.

Garcia-Castallanos, D., Cloetingh, S. \& Van Balen, R., 2000. Modelling the Middle Pleistocene uplift in the Ardennes-Rhenish Massif: themo-mechanical weakening under the Eifel? Global Plan. Change 27: 39-52.

Gaupp, R. \& Okkerman, J.A., 2011. Diagenesis and reservoir quality of Rotliegend sandstones in the northern Netherlands - A review. SEPM Special Publication 98: 193-226.

Griffioen, J. \& Broers, H.P., 1993. Characterization of sediment reactivity: the feasibility of sequential extraction techniques. TNO Institute of Applied Geoscience, report no. 0S93-65A.

Griffioen, J. \& Keijzer, T., 2001. Biogeochemical cycles of chloride, nitrogen, sulphate and iron in a phreatic aquifer system in the Netherlands. In: Cidu, $\boldsymbol{R}$. (ed.): Proceedings of the 10th International Symposium on Water-Rock Interaction, Vol. 1. Balkema Publications (Lisse): 521-524.

Griffioen, J., Passier, H. \& Klein, J., 2008. Comparison of selection methods to deduce natural background levels for groundwater units. Environmental Science \& Technology 42: 4863-4869.

Griffioen, J., Klein, J. \& Van Gaans, P.F.M., 2012. Reaction capacity characterisation of shallow sedimentary deposits in geologically different regions of the Netherlands. Journal of Contaminant Hydrology 127: 30-46.
Griffioen, J., Vermooten, S. \& Janssen, G.J.A., 2013. Geochemical and palaeohydrological controls on the composition of shallow groundwater in the Netherlands. Applied Geochemistry 39: 129-149.

Guggenheim, S. \& Koster van Gross, A.F., 2001. Baseline studies of the clay minerals society source clays: thermal analysis. Clays and Clay Mineralogy 49: 433-443.

Hakstege, A.L., Kroonenberg, S.B. \& Van Wijck, H., 1993. Geochemistry of Holocene clays of the Rhine and Meuse rivers in the central-eastern Netherlands. Geologie \& Mijnbouw 71: 301-315.

Harmsen, G.W., 1954. Observations on the formation and oxidation of pyrite in the soil. Plant Soil V: 324-348.

Harseveldt, H.M., 1973. The discovery of uranium at Haamstede (Netherlands). Verhandelingen van het Koninklijk Nederlands Geologisch en Mijnbouwkundig Genootschap 29: 63-72.

Hartog, N., Griffioen, J. \& Van der Weijden, C.H., 2002. Distribution and reactivity of 02-reducing components in sediments from a layered aquifer. Environemntal Science \& Technology 36: 2338-2344.

Hartog, N., Van Bergen, P.F., De Leeuw, J.W. \& Griffioen, J., 2004. Reactivity of organic matter in aquifer sediments: Geological and geochemical controls. Geochimica et Cosmochimica Acta 68: 1281-1292.

Hartog, N., Griffioen, J. \& Van Bergen, P.F., 2005. Depositional and paleohydrogeological controls on the reactivity of organic matter and other reductants in aquifer sediments. Chemical Geology 216: 113-131.

Heederik, J.P. (ed.), 1989. Geothermal resources in the Central Graben area, the Netherlands. TNO-DGV, report no. 0S89-18: $180 \mathrm{pp.}$

Heerdink, R. \& Griffioen, J., 2012. Geochemische karakterisering van de geotop van Noord-Nederland (hoofdgebied 5). Gehaltes en associaties van hoofd- en sporenelementen. TN0 Energie, rapportno. TN02012R10136: 227 pp.

Hellings, L., Dehairs, F., Tackx, M., Keppens, E. \& Baeyens, W., 1999. Origin and fate of organic carbon in the freshwater part of the Scheldt estuary as traced by stable carbon isotope composition. Biogeochemistry 47: 167-186.

Hemel, R.B.J. \& Stuurman, R.J., 1999. Kalk en kwel. Calciumrijke kwel en de verbreiding en genese van kalkrijke sedimenten in de Centrale Slenk. Stromingen 5: 5-25.

Henningsen, D., 1987. Schwermineralen-Kennzahlen von Quartärsedimenten Nordwestdeutschland (Typical heavy mineral ratios in NW German Quaternary sediments). Zeitschrift Deutsche Geologische Gesellschaft 138: 45-52.

Hoek, W.Z., Bohncke, S.J.P., Ganssen, G.M. \& Meijer, T., 1999. Lateglacial environmental changes recorded in calcareous gyttja deposits at Gulickhof, southern Netherlands. Boreas 28: 416-432.

Hordijk, C.A., Van Engelen, J.J.M., Jonker, F.A. \& Cappenberg, T.E., 1989. Determination of total sulfur in freshwater sediments by ion chromatography. Water Research 23: 853-859.

Hoselmann, Ch. \& Streif, H.J., 2004. Holocene sea-level rise and its effect on the mass balance of coastal deposits. In: Streif, H.J. (ed.): Geological processes and human interaction on the German North Sea Coast. Quaternary International 112: 89-103.

Huisman, D.J., 1998. Geochemical characterization of subsurface sediments in the Netherlands. Ph.D. thesis, Landbouwuniversiteit (Wageningen): $175 \mathrm{pp}$.

Huisman, D.J., 1999. Bulk geochemie als karteringsgereedschap. TNO-NITG, rapportno. NITG 99-1-B: 45 pp. + enclosures. 
Huisman, D.J. \& Kiden, P., 1998. A geochemical record of Late Cenozoic sedimentation history in the southern Netherlands. Geologie \& Mijnbouw 76: 277-292.

Huisman, D.J., Klaver, G.T., Veldkamp, A. \& Van Os, B.J.H., 2000. Geochemical compositional changes at the Pliocene-Pleistocene transition in fluviodeltaic deposits in the Tegelen-Reuver area (southeastern Netherlands). International Journal of Earth Science 89: 154-169.

Hyacinthe, C. \& Van Cappellen, P., 2004. An authigenic iron phosphate in estuarine sediments: composition, formation and chemical reactivity. Marine Chemistry 91: 227-251.

Irion, G. \& Zöllmer, V., 1999. Clay mineral associations in fine-grained surface sediments of the North Sea. Journal of Sea Research 41: 119-128.

Irion, G., Wunderlich, F. \& Schwedhelm, E., 1987. Transport of clay minerals and anthropogenic components into the German Bight and the provenance of fine-grained sediments SE of Helgoland. Journal of the Geological Society 144: $153-160$.

Jakobsen, $R$. \& Cold, L., 2007. Geochemistry at the sulfate reduction - methanogenesis transition zone in an anoxic aquifer - A partial equilibrium interpretation using 2D reactive transport modeling. Geochimica et Cosmochimica Acta 71: 1949-1966.

Janse, J.H., Scheffer, M., Lijklema, L., Van Liere, L., Sloot, J.S. \& Mooij, W.M., 2010. Estimating the critical phosphorus loading of shallow lakes with the ecosystem model PCLake: Sensitivity, calibration and uncertainty. Ecological Modelling 221: 654-665.

Jongmans, A.G. \& Miedema, R., 1986. Morphology, genesis, and distribution of calcareous material in Late Weichselian sediments of the Rhine and Meuse rivers in the eastern part of the Netherlands. Netherlands Journal of Agricultural Science 34: 441-448.

Joosten, I., 2004. Technology of early historical iron production in the Netherlands. Ph.D. thesis, Vrije Universiteit (Amsterdam): 132 pp.

Kasse, K., 1988. Early-pleistocene tidal and fluviatile environments in the Southern Netherlands and Northern Belgium. Ph.D. thesis, Vrije Universiteit (Amsterdam).

Keijzer, T. \& Griffioen, J., 2012. Sedimentmineralogische variatie in de geochemische samenstelling van de geotop van Zeeland. TNO, rapportno. TN02012 R10906: $55 \mathrm{pp}$

Klein, J. \& Griffioen, J., 2008. Het topsysteem van de ondergrond: Een reactievat. Deelrapport 8. Pilot-studie naar de reactiecapaciteit van twee geologische formaties in Noord-Brabant. TN0-Alterra rapportno. 2008-U-R0797/A.

Klein, J. \& Griffioen, J., 2010. Organisch materiaal, kalk en zwavel in sediment: Uitwerking van analyses naar gehaltes. TNO Bouw en Ondergrond, rapportno. TN0-034-UT-2010-0 2327/A.

Klein, J. \& Griffioen, J., 2012. Geochemische karakterisering van de geotop van Noord-Nederland (hoofdgebied 5). De reactiecapaciteit van afzettingen in de geotop van Noord-Nederland. TNO Geological Survey of the Netherlands, rapportno. TN0-034-UT-2010-0 1286: 165 pp.

Knox, R., Bosch, A., Rasmussen, E.S., Heilmann-Clausen, C., Hiss, M., de Lugt, I., Kasinski, J., King, C., Köthe, A., Słodkowska, B., Standke, G. \& Vandenberghe, N., 2010. Cenozoic. In: Doornenbal, J.C. \& Stevenson, A.G. (eds): Petroleum Geological Atlas of the Southern Permian Basin Area. EAGE Publications (Houten): 211-223.

Koelmans, A.A., 1998. Geochemistry of suspended and settling solids in two freshwater lakes. Hydrobiologia 364: 15-29.
Koenen, M.L. \& Griffioen, J., 2013. Geochemical characterisation of the Boom Clay. Report OPERA-PU-TN0521-1: 103 pp.

Konert, M. \& Vandenberghe, J., 1997. Comparison of laser grain size analysis with pipette and sieve analysis: a solution for the underestimation of the clay fraction. Sedimentology 44: 523-535.

Kooistra, M.J., 1978. Soil development in recent marine sediments of the intertidal zone in the Oosterschelde - the Netherlands. A soil micromorphological approach. Ph.D. thesis, University of Amsterdam (Amsterdam): 183 pp.

Kooistra, M.J., 1981. The determination of iron, manganese, sulphur and phosphorus in thin sections of recent marine intertidal sediments in the south-west of the Netherlands by SEM-EDXRA. In: Bisdom, E.B.A. (ed.): Submicroscopy of soils and weathered rocks. PUDOC (Wageningen): 217-236.

Kotska, J.E., Wu, J., Nealson, K.H. \& Stucki, J.W., 1999. The impact of structural $\mathrm{Fe}(\mathrm{III})$ reduction by bacteria on the surface chemistry of smectite clay minerals. Geochimica et Cosmochimica Acta 63: 3705-3713.

Krippner, A. \& Bahlburg, H., 2013. Provenance of Pleistocene Rhine Middle Terrace sands between the Swiss-German border and Cologne based on U$\mathrm{Pb}$ detrital zircon ages. International Journal of Earth Science (Geologische Rundschau) 102: 917-932.

Kuhlmann, G., De Boer, P.L., Pedersen, R.B. \& Wong, Th.E., 2004. Provenance of Pliocene sediments and paleoenvironmental changes in the southern North Sea region using Samarium-Neodymium $(\mathrm{Sm} / \mathrm{Nd})$ provenance ages and clay mineralogy. Sedimentary Geology 171: 205-226.

Laane, R.W.P.M., Turkstra, E. \& Mook, W.G., 1990. Stable carbon isotope composition of pelagic and benthic organic matter in the North Sea and adjacent estuaries. In: Ittekot, V., Kempe, S., Michaelis, W. \& Spitzy, A. (eds): Facets of modern biogeochemistry. Springer Verlag (Berlin): 214-224.

Laban, C., 1988. Fosforietknollen ooit gewonnen als delfstof. Grondboor \& Hamer 42: 33-38.

Laenen, B. \& De Craen, M., 2004. Eogenetic siderite as an indicator for fluctuations in sedimentation rate in the Oligocene Boom Clay Formation (Belgium). Sedimentary Geology 163: 165-174.

La Force, M.J. \& Fendorf, S., 2000. Solid-phase iron characterization during common selective sequential extractions. Soil Science Society of America Journal 64: 1608-1615.

Landuydt, C.J., 1990. Micromorphology of iron minerals from bog ores of the Belgian Campine area. Developments in Soil Science 19: 289-294.

Lardinois, D., Eisma, D. \& Chen, S., 1995. Seasonal differences in concentrations of particulate lipids, proteins and chitin in the North Sea. Netherlands Journal of Sea Research 33: 147-161.

Larsen, G. \& Dinesen, A., 1959. Vejle Fjord Formationen ved Brejning. Danmarks Geologiske Undersøgelse 2: 82.

Larsen, G. \& Friis, H., 1973. Sedimentologiske undersogelser af det jydiske ungTertiaer. Meddelelser fra Dansk Geologisk Forening 119-128.

Limmer, D.R., Köhler, C.M., Hiller, S., Moreton, S.G., Tabrez, A.R., \& Clift, P.D., 2012. Chemical weathering and provenance evolution of HoloceneRecent sediments from the western Indus Shelf, Northern Arabian Sea inferred from physical and mineralogical properties. Marine Geology 326-328: 101-115.

Loope, D.B., Kettler, R.M., Weber, K.A., Hinrichs, N.L. \& Burgess, D.T., 2012. Rinded iron-oxide concretions: hallmark of altered siderite masses of both early and late diagenetic origin. Sedimentology 59: 1769-1781. 
Ludwig, G. \& Figge, K., 1979. Schwermineralenvorkommen und Sandverteilung in der deutschen Bucht (Heavy mineral occurrences and sand distribution in the German Bight). Geologisch Jahrbuch D32: 23-68.

Mariotti, A., Lancelot, C. \& Billen, G., 1984. Natural isotopic composition of nitrogen as a tracer of origin for suspended organic matter in the Scheldt estuary. Geochimica et Cosmochimica Acta 48: 549-555.

Marnette, E.C.L., Van Breemen, N., Hordijk, K.A. \& Cappenberg, T.E., 1993. Pyrite formation in two freshwater systems in the Netherlands. Geochimica et Cosmochimica Acta 57: 4165-4177.

Martin, J.M., Nirel, P. \& Thomas, A.J., 1987. Sequential extraction techniques: Promises and problems. Marine Chemistry 22: 313-341.

Massmann, G., Pekdeger, A. \& Merz, C., 2004. Redox processes in the Oderbruch polder groundwater flow system in Germany. Applied Geochemistry 19: 863886.

McCave, I.N., 1987. Fine sediment sources and sinks around the East Anglian Coast (UK). Journal of the Geological Society 144: 149-152.

McManus, J.P. \& Prandle, D., 1997. Development of a model to reproduce observed suspended sediment distributions in the Southern North Sea using Principal Component analysis and Multiple Linear Regression. Continental Shelf Research 17: 761-778.

Meijs, E., Mucher, H., Ouwerkerk, G., Romein, A. \& Stoltenberg, H., 1983. Evidence of the presence of the Eltville Tuff layer in Dutch and Belgian Limbourg and the consequences for the loess stratigraphy. Eiszeitalter und Gegenwart 33: 59-78.

Middelburg, J.J. \& Herman, P.M.J., 2007. Organic matter processing in tidal estuaries. Marine Chemistry 106: 127-147.

Middelburg, J.J. \& Nieuwenhuize, J., 1998. Carbon and nitrogen stable isotopes in suspended matter and sediments from the Schelde estuary. Marine Chemistry 60: 217-225.

Middelkoop, H., Erkens, G. \& Van der Perk, M., 2010. The Rhine delta - a record of sediment trapping over time scales from millennia to decades. Journal of Soils and Sediments 10: 628-639.

Miedema, R., Jongmans, A.G. \& Slager, S., 1973. Micromorphological observations on pyrite and its oxidation products in four Holocene alluvial soils in the Netherlands. In: Soil Microscopy, Proceedings of the 4th International Working-Meeting on Soil Micromorphology. The Limestone Press (Kingston, Canada): 772-794.

Mitetzky, P., Conzonno, V. \& Fernandez Cirelli, A., 2001. Geochemical processes controlling silica concentrations in groundwaters of the Salado River drainage basin, Argentina. Journal of Geochemical Exploration 73: 155-166.

Mol, G., 2002. Soil acidification monitoring in the Netherlands. Ph.D. thesis, Utrecht University (Utrecht): 144 pp.

Morse, J.W. \& Arvidson, R.S., 2002. The dissolution kinetics of major sedimentary carbonate minerals. Earth-Science Reviews 58: 51-84.

Moura, M.L. \& Kroonenberg, S.B., 1990. Geochemistry of Quaternary fluvial and eolian sediments in the southeastern Netherlands. Geologie \& Mijnbouw 69: 359-373.

Mücher, H.J., 1973. Enkele aspecten van de loess en zijn noordelijke begrenzing, in het bijzonder in Belgisch en Nederlands Limburg en in het daaraangrenzende gebied in Duitsland. K.N.A.G. Geografisch Tijdschrift VII: 259-276.

Mulder, J.P.M., 2000. Zandverliezen in het Nederlandse kustsysteem, Advies voor dynamische handhaven in de 21e eeuw. Rapport RIKZ/2000.36. Rijkswaterstaat RIKZ (The Hague).
Müller, G. \& Forstner, U., 1975. Heavy metals in the Elbe and Rhine estuaries: mobilization or mixing effect? Environmental Geology 1: 33-39.

Nelson, H.W. \& Niggli, E., 1950. Röntgenologisch onderzoek van de ondoorzichtige zware fractie van enkele Nederlandse zanden. Proceedings of the Koninklijke Nederlandse Akademie van Wetenschappen LIII, nr. 8: 12401246.

NEN 5104, 1989. Geotechniek. Classificatie van onverharde grondmonsters. Nederlands Normalisatie-instituut, Nederlandse Norm (Delft)

NHV , 2004. Water in the Netherlands: Managing checks and balances. Netherlands Hydrological Society, special 6. www.nhv.nu.

Nielsen, O.B., Rasmussen, W.E.S. \& Thyberg, B.I., 2015. Distribution of clay minerals in the northern North Sea basin during the Paleogene and Neogene: A result of source-area geology and sorting processes. Journal of Sedimentary Research 85: 562-581.

Nriagu, J.O. \& Dell, C.I., 1974. Diagenetic formation of iron phosphate in recent lake sediments. American Mineralogist 59: 934-946.

Oenema, 0., 1988. Diagenesis in subrecent marine sediments in the Eastern Scheldt, southwest Netherlands. Netherlands Journal of Sea Research 22: 253-265.

Oenema, O., 1990a. Pyrite accumulation in salt marshes in the Eastern Scheldt, southwest Netherlands. Biogeochemistry 9: 75-98.

Oenema, 0., 1990b. Sulfate reduction in fine-grained sediments in the Eastern Scheldt, southwest Netherlands. Biogeochemistry 9: 53-74.

Oenema, S., 1990c. Pseudogaylussite in het Nederlandse en Duitse kustgebied. Grondboor \& Hamer 44: 106-108.

Ohfuji, H. \& Rickard, D., 2005. Experimental syntheses of framboids - a review. Earth-Science Reviews 71: 147-170.

Oost, A.P., Hoekstra, P., Wiersma, A., Flemming, B., Lammerts, E.J., Pejrup, M., Hofstede, J., Van der Valk, B., Kiden, P., Bartholdy, J., Van der Berg, M.W., Vos, P.C., De Vries, S. \& Wang, Z.B., 2012. Barrier island management: Lessons from the past and directions for the future. Ocean \& Coastal Management 68: 18-38.

Otto, L., Zimmerman, Furnes, G.K., Mork, M., Saetre, R. \& Becker, G., 1990. Review of the physical oceanography of the North Sea. Netherlands Journal of Sea Research 26: 161-238.

Overeem, I. \& Kroonenberg, S.B., 2002. De Amazone in de Noordzee. Natuur en Techniek 70(1): 66-71.

Overeem, I., Weltje, G. J., Bishop-Kay, C. \& Kroonenberg, S. B., 2001. The Late Cenozoic Eridanos delta system in the Southern North Sea Basin: a climate signal in sediment supply? Basin Research 13: 293312.

Pache, T., Brockamp, 0. \& Clauer, N., 2008. Varied pathways of river-borne clay minerals in a near shore marine region: A case study of sediments from the Elbe- and Weser rivers, and the SE North Sea. Estuarine and Coastal Shelf Science 78: 563-575.

Pons, L.J., 1957. Geology, soil formation and history of the drainage conditions in the Land van Maas en Waal and a part of The Rijk van Nijmegen. Ph.D. thesis, Agricultural University (Wageningen).

Poot, A., Gillissen, F. \& Koelmans, A.A., 2007. Effects of flow regime and flooding on heavy metal availability in sediment and soil of a dynamic river system. Environmental Pollution 148: 779-787.

Post, V.E.A., 2006. Enkele opmerkingen over kalkzandsteenbanken. Grondboor \& Hamer 1-2006: 2-5. 
Pouclet, A. \& Juvigne, E., 2009. The Elville Tephra, a Late Pleistocene widespread tephra layer in Germany, Belgium and the Netherlands; symptomatic compositions of the minerals. Geologica Belgica 12: 93-103.

Price, F.T. \& Casagrande, D.J., 1991. Sulfur distribution and isotopic composition in peats from the Okefenokee Swamp, Georgia and the Everglades, Florida. International Journal of Coal Geology 17: 1-20.

Prommer, H. \& Stuyfzand, P.J., 2005. Identification of temperature-dependent water quality changes during a deep well injection experiment in a pyritic aquifer. Environmental Science \& Technology 39: 2200-2209.

Rappol, M., 1983. Glacigenic properties of till. Studies in glacial sedimentology from the Allgau Alps and The Netherlands. Ph.D. thesis, University of Amsterdam (Amsterdam): 225 pp.

Rappol, M. , 1984. Till in southeast Drente and the origin of the Hondsrug complex, the Netherlands. Eiszeitalter und Gegenwart 34: 7-27.

Rappol, M., 1986. Saalian till in The Netherlands: A review. In: INQUA Symposium on Genesis and Lithology of Glacial Deposits/Amsterdam. Balkema (Amsterdam): 3-20.

Reinders, G., 1902. Mededeeling omtrent de verspreiding van het deels poedervormig deels pijpvormig ijzeroer in de provinciën Groningen en Drente. Verh. Kon. Akad. Wet. Amsterdam 9(2): 3-18, met kaart.

Reinhold, Th., 1925. Eenige opmerkingen over de chemische samenstelling van löss. In: Van Schuiling, R. (ed.): Gedenkboek ter herinnering aan den 70sten verjaardag van R. Schuiling, 27 mei 1924. Noordhoff (Groningen): 237-248.

RGD, 1989. Pyrietonderzoek t.b.v. de nitraatproblematiek bij het P.S. Vierlingbeek. Rijks Geologische Dienst, rapport BP 10744: 21 pp. + enclosures.

Rickard, D. \& Morse, J.W., 2005. Acid volatile sulfide (AVS). Marine Chemistry 97: 141-197.

Riezebos, P.A., 1968. Mineralogical composition of material less than 500 micron from a red and a grey boulder clay sample in the Netherlands. Geologie \& Mijnbouw 47: 98-101.

Riezebos, P.A., 1971. A contribution to the sedimentary-petrological description of the Maas deposits in Southern Limburg (the Netherlands). Geologie \& Mijnbouw 50: 505-514.

Riezebos, P.A. \& Rappol, M., 1987. Gravel- to sand-sized vivianite components in a Saalian till layer near Borne (The Netherlands). Geologie \& Mijnbouw 66: 21-34.

Riezebos, P.A., Bisdom, E.B.A. \& Boersma, O., 1978. Composite grains in Maas (Meuse) sediments: A survey and a discussion of their opaque components. Geologie \& Mijnbouw 57: 417-431.

Ritsema, C.J. \& Groenenberg, J.E., 1993. Pyrite oxidation, carbonate weathering, and gypsum formation in a drained potential acid sulfate soil. Soil Science Society of America Journal 57: 968-976.

Rivaz Perez, J., Banwart, S.A. \& Puigdomenech, I., 2005. The kinetics of 02(aq) reduction by structural ferrous iron in naturally occuring ferrous silicate minerals. Applied Geochemistry 20: 2003-2016.

Römkens, P.F.A.M., Hassink, J. \& Van der Plicht, J., 1998. Soil organic 14 C dynamics: Effects of pasture installation on arable land. Radiocarbon 40 : 1023-1031.

Römkens, P.F.A.M., Van der Plicht, J. \& Hassink, J., 1999. Soil organic matter dynamics after the conversion of arable land to pasture. Biology and Fertility of Soils 28: 277-284.
Roskam, G., Klaver, G. \& Griffioen, J., 2008. Methodeontwikkeling voor het bepalen van het gehalte reactief ijzer. TNO Bouw en Ondergrond/Deltares, rapportno. 2008-U-R1288/A.

Rozema, J., Broekman, R., Ernst, W.H.O. \& Appelo, C.A.J., 1985. On the lime transition and decalcification in the coastal dunes of the province of NorthHolland and the island of Schiermonnikoog. Acta Botanica Neerlandica 34: 393-411.

Sabbe, K., 1993. Short-term fluctuations in benthic diatom numbers on an intertidal sandflat in the Westerschelde estuary (Zeeland, the Netherlands). Hydrobiologia 269/270: 275-284.

Salomons, W., 1975. Chemical and isotopic composition of carbonates in recent sediments and soils from western Europe. Journal of Sedimentary Petrology 45: 440-449.

Salomons, W. \& Mook, W.G., 1980. Biogeochemical processes affecting metal concentrations in lake sediments (IJsselmeer, the Netherlands). Science of the Total Environment 16: 217-229.

Salomons, W. \& Mook, W.G., 1981. Field observations of the isotopic composition of particulate organic carbon in the southern North Sea and adjacent estuaries. Marine Geology 41: M11-M20.

Salomons, W., Hofman, P., Boelens, R. \& Mook, W.G., 1975. The oxygen isotopic composition of the fraction less than 2 microns (clay fraction) in recent sediments from western Europe. Marine Geology 18: M23-M28.

Salvador, A. (ed.), 1994. International Stratigraphic Guide. A Guide to stratigraphic classification, terminology, and procedure, 2nd edn. International Subcommission on Stratigraphic Classification of IUGS International Commission on Stratigraphy. International Union of Geological Sciences/Geological Society of America (Trondheim/Boulder): $214 \mathrm{pp}$.

Sané, E., Isla, E., Angeles Barcena, M. \& DeMaster, D.J., 2013. A shift in the biogenic silica of sediment in the Larsen B continental shelf, off the Eastern Antarctic peninsula, resulting from climate change. PLOS One 8(1): e52632.

Schäfer, A., Utescher, T., Klett, M. \& Valdivia-Manchego, M., 2005. The Cenozoic Lower Rhine Basin - rifting, sedimentation, and cyclic stratigraphy. International Journal of Earth Science Geologische Rundschau 94: 621-639.

Scheres, W., 2007. Siderietconcreties langs de Maas te Venlo. Gea 40: 22-25.

Schokker, J., 2003. Patterns and Processes in a Pleistocene fluvio-aeolian environment: Roer Valley Graben, south-eastern Netherlands. Ph.D. thesis, Utrecht University (Utrecht): $142 \mathrm{pp}$.

Schokker, J., Cleveringa, P., Murray, A.S., Wallinga, J. \& Westerhoff, W.E., 2005. An OSL-dated Middle- and Late-Quaternary sedimentary record in the Roer Valley Graben (southeastern Netherlands). Quaternary Science Reviews 24: 2243-2264.

Schokker, J., Weerts, H.J.T., Westerhoff, W.E., Berendsen, H.J.A. \& Den Otter, C., 2007. Introduction of the Boxtel Formation and implications for the Quaternary lithostratigraphy of the Netherlands. Netherlands Journal of Geosciences/Geologie \& Mijnbouw 86: 197-210.

Schoute, J.F.Th., Bisdom, E.B.A., Schoonderbeek, D., Boersma, O.H., Schreiber, D. \& Vos, E.C., 1992. Microscopisch onderzoek van glauconiethoudende zanden bij Ellewoutsdijk/Borssele in de provincie Zeeland. Report 233. DL0 Staring Centrum (Wageningen): $41 \mathrm{pp}$.

Schuiling, R.D., De Meijer, R.J., Riezebos, H.J. \& Scholten, M.J., 1985. Grain size distribution of different minerals in a sediment as a function of their specific density. Geologie \& Mijnbouw 64: 199-203. 
Schüttenhelm, R.T.E. \& Laban, C., 2005. Heavy minerals, provenance and large scale dynamics of seabed sands in the Southern North Sea: Baak's (1936) heavy mineral study revisited. Quaternary International 133-134: 179193.

Schwartz, C., 1996. Die Bohrungen 89/3, 89/4 und 89/9 auf dem deutschen Nordseeschelf-Sediementologische und magnetostratigrafische Befunde sowie lithostratigraphische Konnektierung. (Boreholes 89/3, 89/4 and 89/9 from the German North Sea shelf-Sedimentological and magnetostratigraphical results and lithostratigraphical correlation). Geol. Jahrbuch A 146: 33-137.

Schwientek, M., Einsiedl, F., Stichler, W., Stoegbauer, A., Strauss, H. \& Maloszewski, $P_{.}, 2008$. Evidence for denitrification regulated by pyrite oxidation in a heterogeneous porous groundwater system. Chemical Geology 255: 60-67.

Selleck, B.W., Carr, P.F. \& Jones, B.G., 2007. A review and synthesis of glendonites (pseudomorphs after ikaite) with new data: assessing applicability as recorders of ancient coldwater conditions. Journal of Sedimentary Research 77: 980-991.

Shearman, D.J. \& Smith, A.J., 1990. Ikaiet, het oorspronkelijke mineraal van de pseudomorfosen van het jarrowiet-type. Grondboor \& Hamer 44: 16-21.

Sival, F.P., 1997. Dune soil acidification threating rare plant species. Ph.D. thesis, Rijksuniversiteit (Groningen): $150 \mathrm{pp.}$

Sival, F.P., Mücher, H.J. \& Van Delft, S.P.J. 1998, Management of basiphilous dune slack communities in relation to carbonate accumulation and hydrological conditions. Journal of Coastal Conservation 4: 91-100.

Skiba, M., 2013. Evolution of dioctahedral vermiculite in geological environments - An experimental approach. Clays and Clay Mineralogy 61: 290-302.

Slager, S., Jongmans, A.G., Miedema, R. \& Pons, L.J., 1978. Fossil and recent soil formation in Late Pleistocene loess deposits in the southern part of the Netherlands. Netherlands Journal of Agricultural Science 26: 326-335.

Slomp, C.P., Malscaert, J.F.P., Lohse, L. \& Van Raaphorst, W., 1997. Iron and manganese cycling in different sedimentary environments on the North Sea continental margin. Continental Shelf Research 17: 1083-1117.

Smittenberg, R.H., Huisman, D.J., Veldkamp, A., Jongmans, A.G. \& Van Os, B.J.H., 1998. Siderite, syn- or postdepositional? A comparison of Early and Late Pleistocene deposits in the Netherlands. In: Huisman, D.J. (ed.): Geochemical characterization of subsurface sediments in the Netherlands. Ph.D. thesis, Landbouwuniversiteit (Wageningen): 67-82.

Spijker, J., 2005. Geochemical patterns in the soils of Zeeland. Natural variability versus anthropogenic impact. Ph.D. thesis, Utrecht University (Utrecht): $205 \mathrm{pp}$.

Steinert, H., 1948. Schwermineralen und Stratigraphie der diluvialen Geschiebemergel von Schleswig-Holstein (Heavy minerals and stratigraphy of Pleistocene tills from Schleswig-Holstein). Ph.D. thesis, Kiel University: $44 \mathrm{pp}$.

Stiboka, 1972. De bodemkaart van Nederland. Toelichting bij de bodemkaart van Nederland 1:200.000. Stichting Bodemkartering (Wageningen).

Street-Parrott, F.A. \& Barker, P.A., 2008. Biogenic silica: a neglected component of the coupled global continental biogeochemical cycles of carbon and silicon. Earth Surf. Process. Landforms 33: 1436-1457.

Streif, H.J., 1990. Das ostfriesische Küstegebiet. Sammlung Geologischer Führer 57. Bornträger (Berlin): 1-376.

Stuyfzand, P., 1993. Hydrochemistry and hydrology of coastal dunes of the Western Netherlands, Ph.D. thesis, Free University (Amsterdam).
Stuyfzand, P.J., Arens, S.M. \& Oost, A.P., 2010. Geochemische effecten van zandsuppleties langs Hollands kust. KWR, VU University Amsterdam, Arens Bureau voor Strand- en Duinonderzoek, Deltares, rapport no. KWR 2010.048: $70 \mathrm{pp}$.

Tambach, T., Veld, H. \& Griffioen, J., 2009. Influence of the mineral matrix on Pollut Eval pyrolysis of organic matter in aquifer sediments. Applied Geochemistry 24: 2144-2151.

Tebbens, L.A., 1999. Late Quaternary evolution of the Meuse fluvial system and its sediment composition. Ph.D. thesis, Wageningen Agricultural University (Wageningen): $155 \mathrm{pp}$.

Tebbens, L.A., Kroonenberg, S.B. \& Van den Berg, M.W., 1995. Compositional variation of detrital garnets in Quaternary Rhine, Meuse and Baltic River sediments in the Netherlands. Geologie \& Mijnbouw 74: 213-224.

Tebbens, L.A., Veldkamp, A. \& Kroonenberg, S.B., 1998. The impact of climate change on the bulk and clay geochemistry of fluvial residual channel infillings: the Late Weichselian and Early Holocene River Meuse sediments (The Netherlands). Journal of Quaternary Science 13: 345-356.

Tebbens, L.A., Veldkamp, A. \& Kroonenberg, S.B., 2000. Natural compositional variation of the river Meuse (Maas) suspended load: a 13 ka bulk geochemical record from the upper Kreftenheije and Betuwe Formations in northern Limburg. Netherlands Journal of Geosciences 79: 391-409.

Terwindt, J.H.J., 1977. Mud in the Dutch delta area. Geologie \& Mijnbouw 56: 203-210.

Terwindt, J.H.J., De Jong, J.D. \& Van Der Wilk, E., 1963. Sediment movement and sediment properties in the tidal area of the lower Rhine (Rotterdam Waterway). Verhandelingen Koninklijk Geologisch Mijnbouwkundig Genootschap 21: 243-258.

Thiry, M., 2000. Palaeoclimatic interpretation of clay mineral in marine deposits: An outlook from the continental origin. Earth-Science Reviews 49: 201-221.

Thomas, J., 2007. Karakterisering van waterbodems van de Dommel in NoordBrabant en de Dinkel in Twente, Overijssel. TNO Netherlands Geol. Survey, report no. 2007-U-R1127/A: 115 pp + enclosures.

Thompson, R., Cameron, T.D.J., Schwarz, C., Jensen, K.A., Maenhaut van Lemberge, V. \& Sha, L.P., 1992. The magnetic properties of Quaternary and Tertiary sediments in the southern North Sea. Journal of Quaternary Science 7: 319-334.

Toucanne, S., Zararagosi, S., Bourillet, J.F., Gibbard, P.L., Eynaud, F., Giraudau, J., Turon, j.L., Cremer, M., Cortijo, E., Martinez, P. \& Rossignol, L., 2009. A 1.2 Ma record of glaciation and fluvial discharge from the West European Atlantic margin. Quaternary Science Reviews 28: 2974-2981.

Turner, A., Millward, G.E. \& Morris, A.W., 1991. Particulate metals in five major North Sea estuaries. Estuarine and Coastal Shelf Science 32: 325-346.

Uncles, R.J., Stephens, J.A. \& Smith, R.E., 2002. The dependence of estuarine turbidity on tidal intrusion length, tidal range and residence time. Continental Shelf Research 22: 1835-1856.

Van Adrichem Boogaert, H.A. \& Kouwe, W.F.P., 1997. Stratigraphic nomenclature of the Netherlands, revision and update by RGD and NOGEPA. Mededelingen Rijks Geologische Dienst no. 50, section 1. Rijks Geologische Dienst (Delft/Haarlem): 1-30.

Van Alphen, J.S.I.B., 1990. A mud balance for Belgian-Dutch coastal waters between 1969 and 1986. Netherlands Journal of Sea Research 25: 19-30.

Van Andel, Tj.H., 1950. Provenance, transport and deposition of Rhine sediments. Proefschrift Rijksuniversiteit (Groningen): 124 pp. 
Van Andel, Tj.H., 1952. Zur Frage der Schwermineralverwitterung in Sedimenten. Erdol Kohle 5: 100.

Van Andel, Tj.H., 1958. Origin and classification of Cretaceous, Paleocene and Eocene sandstones in Western Venezuela, Am. Ass. Petroleum Geologist Bulletin 42: 734-763.

Van Balen, R.T., Houtgast, R.F. \& Cloetingh, S.A.P.L., 2005. Neotectonics of The Netherlands: a review. Quaternary Science Reviews 24: 439-454.

Van Baren, J., 1916. Oudere en jongere löss in Nederland. Tijdschrift van het Koninklijk Nederlands Aardrijkskundig Genootschap 33: 201-205 + 2 photos.

Van Baren, J., 1926. Bijdrage tot de kennis van pseudo-gaylussiet. Med. Geol. Inst. Landbouwh. No. X (Wageningen): $24 \mathrm{pp}$. + enclosures.

Van Baren, F.A., 1934. Het voorkomen en de betekenis van kalihoudende mineralen in Nederlandsche gronden. Ph.D. thesis, Landbouw Hogeschool (Wageningen).

Van Beek, C.G.E.M. \& Hettinga, F.A.M., 1989. The effects of manure spreading and acid deposition upon groundwater quality at Vierlingsbeek, the Netherlands. In: Abriola, L.M. (ed.): Groundwater contamination. IAHS Publication no. 185. International Association Hydrological Sciences (0xfordshire): 155162.

Van Bemmelen, J.M., 1863. Bouwstoffen tot de Kennis van de Kleigronden in de provincie Groningen. Scheikundige Verhandelingen en Onderzoekingen, deel III, stuk 2, blz: 146-154, 216-249.

Van Bemmelen, J.M., 1896. Over de samenstelling, het voorkomen en de vorming van Sideroze (witte klien) en van vivianiet in de onderste darglaag der hoogveenen. Verhand. Kon. Akad. V. Wetensch. (1e sectie): Dl. III: 3-16.

Van Bemmelen, J.M. \& Reinders, G., 1901. Twee nieuwe vindplaatsen van moerasijzersteen in en onder veen. Verh. Kon. Akad. Wet. Amsterdam, deel 9: 406-418.

Van Dam, D. \& Pons, L.J., 1972. Micropedological observations on pyrite and its pedological reaction products. Proc. Int. Symp. On Acid Sulphate Soils, Wageningen, August 13-20: 169-196.

Van de Meent, D., De Leeuw, J.W. \& Schenck, P.A., 1980. Chemical characterization of non-volatile organics in suspended matter and sediments of the river Rhine delta. Journal of Analytical and Applied Pyrolysis 2: 249263.

Van de Meent, D., De Leeuw, J.W., Schenck, P.A. \& Salomons, W., 1985. Geochemistry of suspended particulate matter in two natural sedimentation basins of the river Rhine. Water Research 19: 1333-1340.

Van den Berg, G.A. \& Loch, J.P.G., 2000. Decalcification of soils subject to periodic water logging. European Journal of Soil Science 51: 27-33.

Van den Berg, G.A., Loch, J.P.G. \& Winkels, H.J., 1998. Effect of fluctuating hydrological conditions on the mobility of heavy metals in soils of a freshwater estuary in the Netherlands. Water, Air, and Soil Pollution 102: 377-388.

Van den Berg, G.A., Loch, J.P.G., Van der Heijdt, L.M. \& Zwolsman, J.J.G., 1999. Mobilisation of heavy metals in contaminated sediments in the river Meuse, The Netherlands. Water, Air, and Soil Pollution 116: 567-586.

Van den Berg, G.A., Buykx, S.E.J., Van den Hoop, M.A.G.T., Van der Heijdt, L.M. \& Zwolsman, J.J.G., 2001. Vertical profiles of trace metals and acidvolatile sulphide in a dynamic sedimentary environment: Lake Ketel, The Netherlands. Applied Geochemistry 16: 781-791.

Vandenberghe, N., Harris, W.B., Wampler, J.M., Houthuys, R., Louwye, S., Adriaens, R., Vos, K., Lanckacker, T., Matthijs, J., Deckers, J., Verhaegen, J., Laga, P., Westerhoff, W. \& Munsterman, D., 2014. The implications of
K-Ar glauconite dating of the Diest Formation on the paleogeography of the Upper Miocene in Belgium. Geologica Belgica 17: 161-174.

Van der Burg, W.J., 1969. The formation of rattle stones and the climatological factors which limited their distribution in the Dutch Pleistocene: 1 . The formation of rattle stones. Paleaogeography, Palaeoclimatology, Palaeoecology 6: 105-124.

Van der Marel, H.W., 1949. Mineralogical composition of a heath podzoil profile. Soil Science 67: 193-207.

Van der Marel, H.W., 1950. Calcite and dolomite in the clay fraction of the Dutch soils. Landbouwk. Tijdschrift 62: 300-305 (in Dutch with English summary).

Van der Meulen, M.J., Westerhoff, W.E., Menkovic, A., Gruijters, S.H.L.L., Dubelaar, C.W. \& Maljers, D., 2009. Silica sand resources in the Netherlands. Netherlands Journal of Geosciences 88: 147-160.

Van der Meulen, M.J., Doornenbal, J.C., Gunnink, J.J., Stafleu, J., Schokker, J., Vernes, R.W., Van Geer, F.C., Van Gessel, S.F., Van Heteren, S., Van Leeuwen, R.J.W., Bakker, M.A.J., Bogaard, P.J.F., Busschers, F.S., Griffioen, J., Gruijters, S.H.L.L., Kiden, P., Schroot, B.M., Simmelink, H.J., Van Berkel, W.O., Van der Krogt, R.A.A., Westerhoff, W.E., \& Van Daalen, T.M., 2013. 3D geology in a 2D country: perspectives for geological surveying in the Netherlands. Netherlands Journal of Geosciences 92-4: 217241.

Van der Molen, J. \& Van Dijck, B., 2000. The evolution of the Dutch and Belgian coasts and the role of sand supply from the North Sea. Global and Planetary Change 27: 223-244.

Van der Salm, C. \& Verstraten, J.M., 1994. Acid neutralization mechanisms in three acid sandy soils. Geoderma 63: 227-243.

Van der Sleen, W.G.N., 1912. Bijdrage tot de kennis der chemische samenstelling van het duinwater in verband met de geo-mineralogische gesteldheid van den bodem. Ph.D. thesis, University of Amsterdam (Amsterdam): 157 pp. + enclosures.

Van der Sluijs, P., 1970. Decalcification of marine clay soils connected with decalcification during silting. Geoderma 4: 209-227.

Van der Sluijs, P. \& Locher, W.P., 1990. Hoofdstuk 5: Korrelgrootte. In: Locher, W.P. \& De Bakker, H. (eds): Bodemkunde van Nederland. Deel 1. Algemene Bodemkunde. Den Bosch (Malmberg): 71-90.

Van Eck, G.T.M., 1982a. Geochemie van zwevend materiaal en water in het Hollands Diep/Haringvliet. Ph.D. thesis, Utrecht University (Utrecht): $273 \mathrm{pp}$.

Van Eck, G.T.M., 1982b. Forms of phosphorus in particulate matter from the Hollands Diep/Haringvliet, the Netherlands. Hydrobiologia 92: 665681.

Van Gaans, P.F.M., Hartog, N., Bakker, I.J.I., Kiden, P. \& Griffioen, J., 2007. Het topsysteem van de ondergrond: Een reactievat. Deelrapport 3. Eerste statistische karakterisering van de geochemische reactiecapaciteit van de geotopgebieden Holland en Rivierengebied. TNO Bouw en Ondergrond/Alterra, rapportno. 2007-U-R1172/A.

Van Gaans, P.F.M., Griffioen, J., Mol, G. \& Klaver, G.T., 2011. Geochemical reactivity of subsurface sediments as potential buffer to anthropogenic inputs: a strategy for regional characterization in the Netherlands. Journal of Soils and Sediments 11: 336-351.

Van Griethuysen, C., Meijboom, E.W. \& Koelmans, A.A., 2003. Spatial variation of metals and acid volatile sulfide in floodplain lake sediment. Environmental Toxicology \& Chemistry 22: 457-465. 
Van Griethuysen, C., Van Baren, J., Peeters, E.T.H.M. \& Koelmans, A.A., 2004. Trace metal availability and effects on benthic community structure in floodplain lakes. Environmental Toxicology \& Chemistry 23: 668-681.

Van Grinsven, H.J.M., Van Riemsdijk, W.H., Otjes, R. \& Van Breeemen, N., 1992. Rates of aluminum dissolution in acid sandy soils observed in column experiments. Journal of Environmental Quality 21: 439-447.

Van Helvoort, P.J., 2003. Complex confining layers. A physical and geochemical characterization of heterogeneous unconsolidated fluvial deposits using a facies-based approach. Ph.D. thesis, Utrecht University (Utrecht): 147 pp.

Van Helvoort, P.J., Filzmoser, P. \& Van Gaans, P.F.M., 2005. Sequential factor analysis as a new approach to multivariate analysis of heterogeneous geochemical datasets: an application to a bulk chemical characterisation of fluvial deposits (Rhine-Meuse delta, the Netherlands). Applied Geochemistry 20: 2233-2251.

Van Helvoort, P.J., Griffioen, J. \& Hartog, N., 2007. Characterization of the reactivity of riverine heterogeneous sediments using a facies-based approach: The Rhine-Meuse delta (the Netherlands). Applied Geochemistry 22: 27352757.

Van Loef, J.J., 2000. Composition and genesis of rattlestones from Dutch soils as shown by Mossbauer spectroscopy, INAA and XRD. Netherlands Journal of Geosciences 79: 59-71.

Van Loon, A.J., 2009. Unravelling the enigsmas of the 'silver sands' in the Dutch, German, Belgian border area. Netherlands Journal of Geosciences 88-3: 133145.

Van Loon, A.J. \& Mange, M.A., 2007. 'In situ' dissolution of heavy minerals through extreme weathering and the application of the surviving assemblages and their dissolution characteristics to correlation of Dutch and German Silver sands. In: Mange, M.A. \& Wright, D.T. (eds): Heavy minerals in use. Developments in Sedimentology 58. Elsevier (Amsterdam): 189-213.

Van Pruissen, F.G.M. \& Zuurdeeg, B.W., 1988. Hoge metaalgehalten in ijzeroerknollen in de Nederlandse bodem. Milieutechniek 3: 84-91.

Van Puijenbroek, P.J.T.M., Jnse, J.H. \& Knoop, J.M., 2004. Integrated modelling for nutrient loading and ecology of lakes in The Netherlands. Ecological Modelling 174: 127-141.

Van Rossum, P., 1996. Verspreiding van arseen in de bodem en het grondwater van de provincie Noord-Holland. Vrije Universiteit (Amsterdam): 52 pp. + appendices.

Van Rossum, P., 1998. Mobilisatie en herkomst van arseen in de bodem van de provincie Noord-Holland. Vrije Universiteit (Amsterdam): 94 pp. + appendices.

Van Schermbeek, P.G., 1889. Twee Nederlanders en een Amerikaan in het binnenland van Noord-China. Heruitgave in Tijdschrift voor Geschiedenis 4: 236-253.

Van Straaten, L.M.J.U., 1954. Composition and structure of recent marine sediments in the Netherlands. Leidse Geologische Mededelingen XIX: 1-100.

Van Straaten, L.M.J.U., 1963. Aspects of Holocene sedimentation in the Netherlands. Verhandelingen van het Koninklijk Nederlands Geologisch en Mijnbouwkundig Genootschap 21: 149-172.

Van Veen, J., 1936. Onderzoekingen in de Hoofden in verband met de gesteldheid van de Nederlandse kust (Measurements in the Straits of Dover, and their relation to the Netherlands coast). Algemeene Landsdrukkerij (The Hague): $252 \mathrm{pp}$.

Verhoeven, B., 1962. On the calciumcarbonate content of young marine sediments. Netherlands Journal of Agricultural Science 10: 58-71.
Verlaan, P.A.J., Donze, M. \& Kuik, P., 1998. Marine vs fluvial suspended matter in the Scheldt estuary. Estuarine and Coastal Shelf Science 46: 873-883.

Vermooten, S., Maring, L., Van Vliet, M. \& Griffioen, J., 2007. Landsdekkende, geologische karakterisering van de regionale grondwatersamenstelling in de geotop van Nederland. Datarapport. TNO Bouw en Ondergrond, rapport no. 2006-U-R0171/A.

Vermooten, S., Griffioen, J., Heerdink, R. \& Visser, A., 2011. Geochemische karakterisering van de geotop van Zeeland. TN0, rapport no. TN0-034-UT2010-02397: $138 \mathrm{pp}$.

Vijver, M.G., Spijker, J., Vink, J.P.M. \& Posthuma, L., 2008. Determining metal origins and availability in fluvial deposits by analysis of geochemical baselines and solid-solution partitioning measurements and modelling. Environmental Pollution 156: 832-839.

Vink, A.P.A., 1949. Contribution to the knowledge of loess and cover sands, in particular of the southeastern Veluwe. Ph.D. thesis, Landbouwhogeschool (Wageningen): 131 pp. (in Dutch).

Visser, A., Broers, H.P., Heerdink, R. \& Bierkens, M.F.P., 2009. Trends in pollutant concentrations in relation to time of recharge and reactive transport at the groundwater body scale. Journal of Hydrology 369: 427-439.

Vos, P.C. \& De Wolf, H., 1993. Reconstruction of sedimentary environments in Holocene coastal deposits of the southwest Netherlands; the Poortvliet boring, a case study of palaeoenvironmental diatom research. Hydrobiologia 269/270: 297-306.

Vosjan, J.H. \& Olanczuk-Neyman, K.M., 1977. Vertical distribution of mineralization processes in tidal sediments. Netherlands Journal of Sea Research 11: 14-23.

Vranken, M., Oenema, 0. \& Mulder, J., 1990. Effects of tide range alterations on salt marsh sediments in the Eastern Scheldt, S.W. Netherlands. Hydrobiologia 195: 13-20.

Vriens, B.P.J.M., 2011. The diagenetic origin of siderite in Early Pleistocene fluviodeltaic deposits in Maalbeek, the Netherlands. M.Sc. thesis, Utrecht University (Utrecht): 49 pp.

Wartel, S., 1977. Composition, transport and origin of sediments in the Schelde estuary. Geologie \& Mijnbouw 56: 219-233.

Watermann, F., Freund, H. \& Gerdes, G., 2004. Distribution and palaeoecological indicator value of diatoms in Holocene coastal deposits of the southern North Sea (Lower Saxony, Germany). Eiszeitalter und Gegenwart 54: 48-70.

Weenig, C.F., 1951. Kristallijne ijzeroxyden en -hydroxyden in de bodem. Boor \& Spade 4: 54-67.

Weerts, H.J.T., Westerhoff, W.E., Cleveringa, P., Bierkens, M.F.P., Veldkamp, J.G. \& Rijsdijk, K.F., 2005. Quaternary geological mapping of the lowlands of The Netherlands, a 21st century perspective. Quaternary International 133134: 159-178.

Westerhoff, W.E., 2009. Stratigraphy and sedimentary evolution. The lower Rhine-Meuse system during the Late Pliocene and Early Pleistocene (southern North Sea Basin). Ph.D. thesis, Vrije Universiteit (Amsterdam).

Westerhoff, W.E. \& Weerts, H.J.T., 2013. Lithostratigraphy. In: Elias, S.A. (ed.): The Encyclopedia of Quaternary Science, Vol 4. Elsevier (Amsterdam): 227242.

Westerhoff, W.E., Kemna, H.A. \& Boenigk, W., 2008. The confluence area of Rhine, Meuse and Belgian rivers: Late Pliocene and Early Pleistocene fluvial history of the northern Lower Rhine Embayment. Netherlands Journal of Geosciences 87: 107-127. 
Weyl, $\boldsymbol{R}_{\text {., }}$ 1949. Jungtertiäre Schlotten in Zechstein von Lieth bei Einshorn. Schr. Naturw. Verh. Schleswig-Holstein 24: 74-80.

Weyl, $R ., 1950$. Schwermineralverwitterung und ihr einfluss auf die Mineralfürung klastischer Sedimente. Erdol Kohle 3: 207-211.

Weyl, $R_{.}, 1952 a$. Zur Frage der Schwermineralen in Sedimenten. Erdol Kohle 5: 29.

Weyl, $\boldsymbol{R}_{\text {., }}$ 1952b. Schwermineral untersuchungen in Schleswig-Holsteinische Jungtertiär. Zeitschrift der Deutschen Geologischen Gesellschaft 104: 99-133.

Weyl, R., 1953. Die Schwermineral-Assoziation der Liether Kaolinsande. Erdol Kohle 8: 6-7.

Wiesner, M.G., Haake, B. \& Wirth, H., 1990. Organic facies of surface sediments in the North Sea. Organic Geochemistry 15: 419-432.

Wilkin, R.T., Barnes, H.L. \& Brantley, S.L., 1996. The size distribution of framboidal pyrite in modern sediments: An indicator of redox conditions. Geochimica et Cosmochimica Acta 60: 3897-3912.

Winkelmolen, A.M. \& Veenstra, H.J., 1974. Size and shape sorting in a Dutch tidal inlet. Sedimentology 21: 107-126.

Winkelmolen, A.M. \& Veenstra, H.J., 1980. The effect of a storm surge on near-shore sediments in the Ameland-Schiermonnikoog area. N. Netherlands. Geologie \& Mijnbouw 59: 97-111.

Wolterbeek, H.Th., Verburg, T.G. \& Van Meerten, Th.G., 1996. On the 1995 flooding of the rivers Meuse, Rhine and Waal in the Netherlands: metal concentrations in deposited river sediments. Geoderma 71: 143156.

Wong, T., Batjes, D.A.J. \& De Jager, J., 2007. Geology of the Netherlands. Royal Netherlands Academy of Arts and Science (Amsterdam): 354 pp.

Zandstra, J.G., 1967. Een zwerfsteentelling bij Wijdemerk (Gaasterland). Grondboor \& Hamer 21: 12-17.

Zandstra, J.G., 1971. Geologisch onderzoek in de stuwwal van de Oostelijke Veluwe bij Hattem en Wapenveld. Mededelingen Rijks Geologische Dienst, N.S. 22: $215-260$.

Zandstra, J.G., 1974. Over de uitkomsten van nieuwe zwerfsteentellingen en een keileemtypeindeling in Nederland. Grondboor \& Hamer 28: 95-108.

Zandstra, J.G., 1983. Fine gravel, heavy mineral and grain-size analyses of Pleistocene, mainly glacigenic deposits in the Netherlands. In: Ehlers, J. (ed.): Glacial deposits in North-West Europe. Balkema (Rotterdam): 361-377.
Zeelmaekers, E., 2011. Computerized qualitative and quantitative clay mineralogy. Introduction and application to known geological cases. Ph.D. thesis, Katholieke Universiteit (Leuven): 397 pp.

Zhang, Y.C., Slomp, C.P., Broers, H.P., Passier, H.F. \& Van Cappellen, P., 2009. Denitrification coupled to pyrite oxidation and changes in groundwater quality in a shallow sandy aquifer. Geochimica et Cosmochimica Acta 73: 6716-6726.

Zhang, Y.C., Slomp, C.P., Broers, H.P., Bostick, B., Passier, H.F., Bottcher, M.E., Omoregie, E.O., Lloyd, J.R., Polya, D.A. \& Van Cappellen, P., 2012. Isotopic and microbiological signatures of pyrite-driven denitrification in a sandy aquifer. Chemical Geology 300-301: 123-132.

Zonneveld, J.I.S., 1946. Beschouwingen naar aanleiding van de korrelgrootte der zware mineralen in zandige sedimenten. Geologie \& Mijnbouw 10: 83-90, 11-12: 93-105.

Zonneveld, J.I.S., 1947. Het Kwartair van het Peelgebied en de naaste omgeving (een sediment petrologische studie). Mededelingen Geologische Stichting Serie C-VI-No 3: 1-223.

Zonneveld, J.I.S., 1958. Litho-stratigrafische eenheden in het Nederlandse Pleistoceen. Mededelingen Geologische Stichting Nieuwe Serie 12: 31-64.

Zuther, M., Brockamp, 0. \& Clauer, N., 2000. Composition and origin of clay minerals in Holocene sediments from the southeastern North Sea. Sedimentology 47: 119-134.

Zuur, A.J., 1936. Over de bodemkundige gesteldheid van de Wieringermeer. Landsdrukkerij (The Hague): $113 \mathrm{pp}+$ enclosures.

Zuur, A.J., 1954. Bodemkunde der Nederlandse bedijkingen en droogmakerijen. Deel B. De hoofdsamenstelling en enkele andere z.g. chemische bestanddelen van de op het water gewonnen gronden. Directie van de Wieringermeer/Landbouwhogeschool: 100 pp.

Zwolsman, J.J.G., 1994. Seasonal variability and biogeochemistry of phosphorus in the Scheldt Estuary, south-west Netherlands. Estuarine and Coastal Shelf Science 39: 227-248.

Zwolsman, J.J.G. \& Van Eck, G.T.M., 1999. Geochemistry of major elements and trace metals in suspended matter of the Scheldt estuary, southwest Netherlands. Marine Chemistry 66: 91-111.

Zwolsman, J.J.G., Berger, G.W. \& Van Eck, G.T.M., 1993. Sediment accumulation rates, historical input, postdepositional mobility and retention of major elements and trace metals in salt marsh sediments of the Scheldt estuary, SW Netherlands. Marine Chemistry 44: 73-94. 